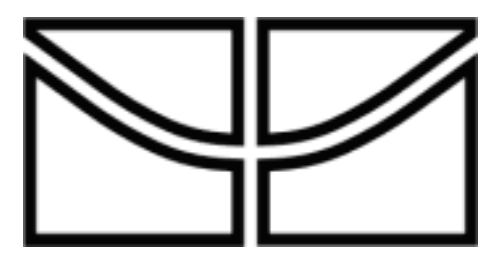

Universidade de Brasília

Instituto de Ciências Biológicas

Departamento de Botânica

Programa de Pós Graduação em Botânica

Taxonomia e Filogenia do gênero Mesosetum Steud. (Poaceae, Paspaleae)

Anádria Stéphanie da Silva 


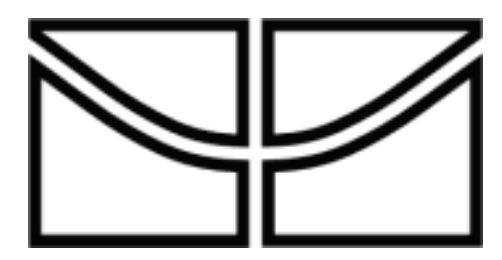

Universidade de Brasília

Instituto de Ciências Biológicas

Departamento de Botânica

Programa de Pós Graduação em Botânica

\section{Taxonomia e Filogenia do gênero Mesosetum Steud. (Poaceae, Paspaleae)}

Tese apresentada ao Programa de Pós-Graduação em Botânica do Departamento de Botânica, Instituto de Ciências Biológicas da Universidade de Brasília (UnB), como parte dos requisitos necessários para obtencão do título de Doutor em Botânica.

Aluna: Anádria Stéphanie da Silva Orientadora: Prof ${ }^{a}$ Dra Regina Célia de Oliveira 


\title{
Taxonomia e Filogenia do gênero Mesosetum Steud. (Poaceae, Paspaleae)
}

\section{Anádria Stéphanie da Silva}

Tese de Doutorado apresentada e aprovada em 23 de fevereiro de 2017.

\author{
Prof $^{a}$. Dr ${ }^{\mathrm{a}}$. Regina Célia de Oliveira, UnB \\ Presidente (Orientadora)
}
Drª . Gláucia Salles Cortopassi Buso, Embrapa/Cenargen
Membro Titular
Dr. José Francisco Montenegro Valls, Embrapa/Cenargen Membro Titular

Prof. Dr. Marcelo Fragomeni Simon, Embrapa/Cenargen Membro Titular

Dr. Márcio de Carvalho Moretzsohn, Embrapa/Cenargen Membro Titular

Prof $^{a}$. Dr ${ }^{a}$. Sueli Maria Gomes, UnB

Suplente 
Aos meus pais Lourdes Carvalho e Carlos Alberto, fonte eterna de força e inspiração.

Dedico 


\section{Agradecimentos}

É difícil agradecer a tantas pessoas e não esquecer alguém, algumas delas foram tão importantes neste trabalho que apenas algumas palavras não seriam suficientes.

Primeiramente agradeço a Deus pelo dom da vida e por renovar diariamente suas forças e fé em mim. Senti a Tua mão misericordiosa em diversos momentos desta caminhada.

Aos meus pais onde eu sempre encontro colo, alento e amor, que proporcionaram todas as condições necessárias para que eu pudesse realizar da melhor maneira possível este trabalho e sempre acreditaram no meu potencial, me apoiando em todos os momentos.

À minha família e amigos que abdicaram de tantos momentos para tornar este sonho realidade, meus irmãos Andréa e Yataanderson, minha tia-avó Tetê e meu sobrinho Carlos Eduardo, pelo amor incondicional, apoio e carinho. Sei que mesmo distantes, torcem por mim. Em especial, a minha mãe e minha irmã, ainda não existem palavras que possam expressar a nossa relação e a minha extrema gratidão por seu amor e companheirismo, sempre dispostas a me ouvir, aconselhar e me mostrar que para tudo há uma solução. Amo vocês.

Ao meu amor, Daniel Crisci, por estar sempre ao meu lado, nos períodos mais difíceis do meu doutorado. Por ter usado o seu carro pessoal durante as expedições de coleta pelos estados do nordeste brasileiro, Bahia, Pernambuco e Piauí. Com a sua parceria e experiência em estradas rústicas e íngremes, consegui coletar espécies de Mesosetum com raríssimos exemplares em herbários.

Ao Programa de Pós-Graduação em Botânica da Universidade de Brasília, que possibilitou a realização desta tese.

A CAPES pela concessão da bolsa de doutorado.

À minha orientadora, Regina Célia de Oliveira, meus sinceros agradecimentos por ter acreditado em mim e ter me proporcionado tantas oportunidades. Até aqui foram 10 anos juntos 
compartilhando alegrias, desafios, sorrisos, conquistas e novas descobertas. Foi um grande orgulho trabalhar com você, sempre serei grata.

À Dra. Gláucia Buso, por ter me acolhido no Laboratório de Genética Vegetal da Embrapa/Cenargen. Pela contínua disponibilidade e amizade que tornaram a realização deste trabalho mais tranquila e prazerosa.

À professora Carolyn Proença e ao Programa Reflora/CAPES pela concessão da bolsa de doutorado sanduíche no Royal Botanic Garden, Kew.

Ao Dr. Peter Inglis, pelas valiosas contribuições com as análises filogenéticas, pela compreensão, pelo aprendizado e por todas as horas gastas em frente ao computador corrigindo as análises.

Ao Dr. José Valls, por todas as expedições de coleta que me proporciou, insprando com sua força e vigor incansáveis, pelas boas horas de histórias contadas, por compartilhar inúmeros ensinamentos e por todo material que me forneceu para o término desse trabalho.

Aos membros da banca examinadora, Dr. Marcelo Simon e Dr. Márcio Moretzsohn, por aceitarem o convite em contribuir com esse trabalho.

A todos os funcionários do herbário UB que de alguma forma contribuíram para a realização deste trabalho.

Aos curadores dos herbários citados ao longo do texto, que gentilmente emprestaram material dos acervos ou que, juntamente com os funcionários, me receberam sempre muito bem.

Aos meus queridos amigos, André, Fernanda, Gláucia, Keidna, Priscila, Suzi, Viviane e Uiara, pelas valiosas e confortantes palavras nos momentos difíceis, pela amizade e carinho de anos. Caso a vida não nos permita dividir a mesma cidade, ainda assim os levarei em meu coração.

Às amigas brasilienses, Janara, Mariana, Márcia, Natália, Rosana e Sílvia pela amizade, por terem compartilhado ótimos momentos que ficarão para sempre guardados em minha lembrança, e principalmente pelas energias positivas que com certeza foram fundamentais em muitos momentos. 
As minhas amigas de Mossoró, Amanda, Dyana, Janeuma, Thábata e Tereza, vocês fazem parte da minha vida desde sempre, mais de 20 anos de amizade, que não importa o tempo que estamos distantes, podemos sempre contar uma com as outras.

Aos amigos do Departamento de Botânica da UnB pela amizade, ajuda nos trabalhos de campo, inclusão do material no herbário, pelos importantes momentos de trabalho e descontração, especialmente Ana Isabel, Antonio, Clapton, Diogo, Gabi, Jair, Janae e as duas Joices.

Às minhas companheiras de moradia na Colina/UnB, as duas Anas, Izabel, as duas Jéssicas e Kézya, pela amizade e por tornar nossa estadia em Brasília muito mais prazerosa e familiar.

A todos os amigos e colegas do Laboratório de Genética Vegetal da Embrapa/Cenargen pelos vários momentos de discussão, aprendizagem e apoio, especialmente aos pesquisadores e funcionários, Lorena, Marcão, Marília, Vânia e Zilneide, aos colegas de bancada, Adriana, Bruna, João Lucas, Lucileide, Nayara, Natasha e Pétala. Foram ótimos momentos de descontração e gordices no cafézinho.

A todos que direta ou indiretamente participaram da execução deste trabalho, pois uma tese deve-se a colaboração, muitas vezes oculta, de diversas pessoas que contribuíram para o seu sucesso. 


\section{Sumário}

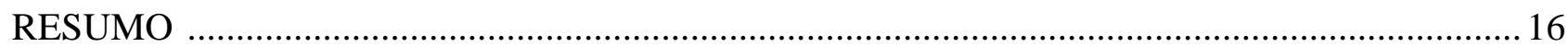

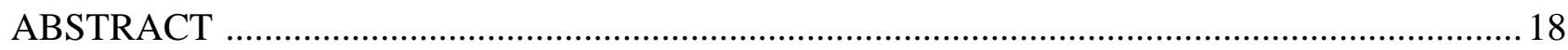

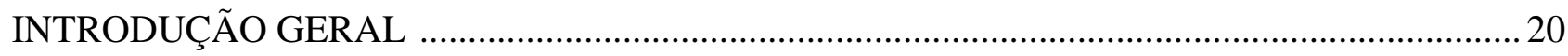

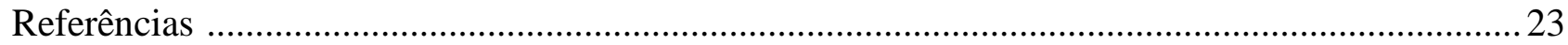

CAPÍTUlO 1: Filogenia de Mesosetum Steud. (Poaceae, Paspaleae) baseada em marcadores

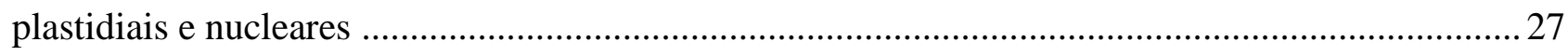

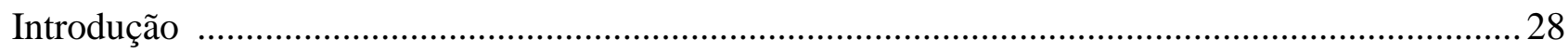

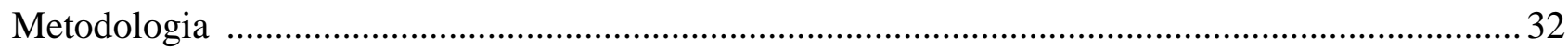

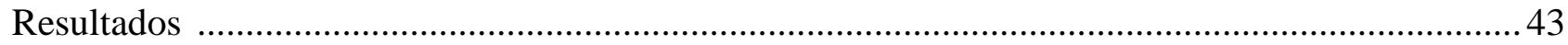

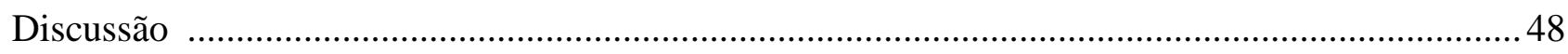

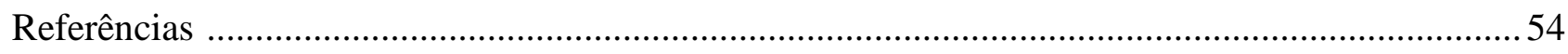

CAPÍTULO 2: Sinopse do gênero Mesosetum Steud. (Poaceae, Paspaleae) ................................. 61

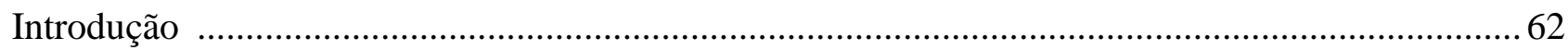

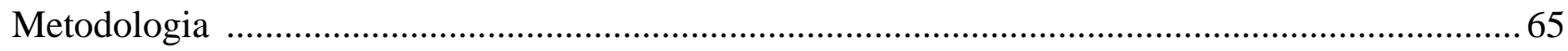

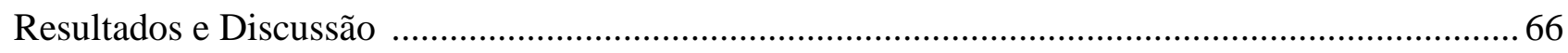

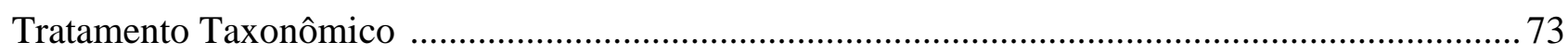

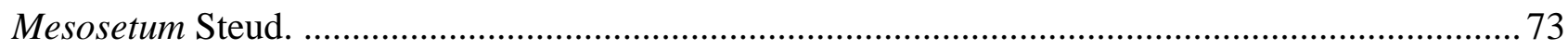

Chave de identificação das espécies de Mesosetum ...................................................................... 74

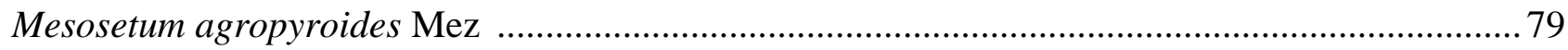

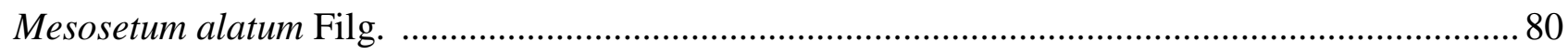

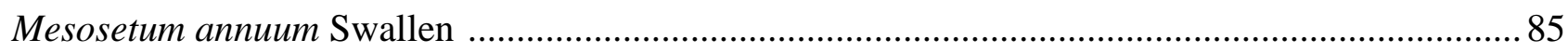

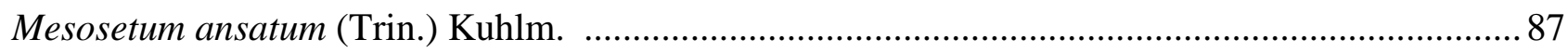

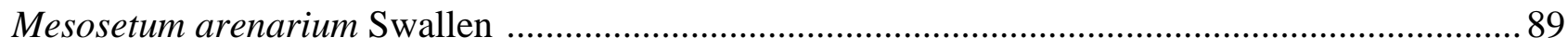

Mesosetum arnacites (Trin.) A.S. Silva \& R.C. Oliveira ........................................................... 90 


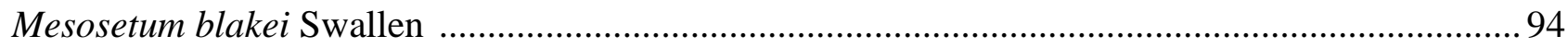

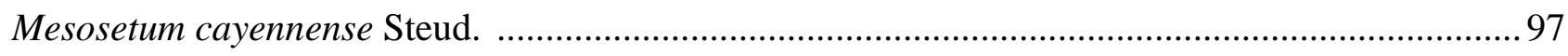

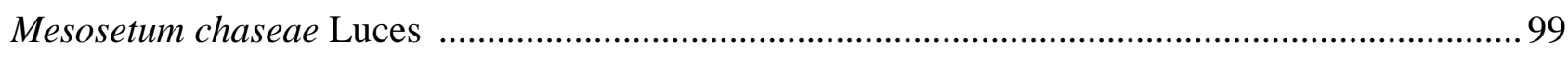

Mesosetum chlorostachyum (Döll) Chase ……........................................................................... 100

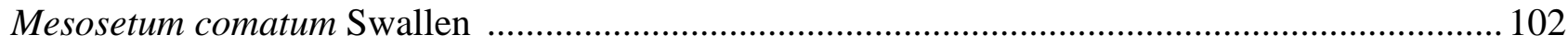

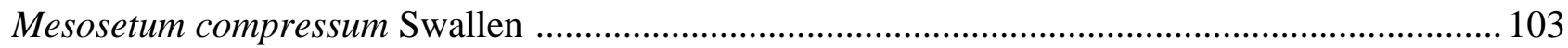

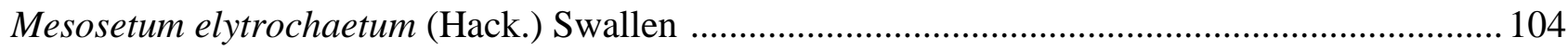

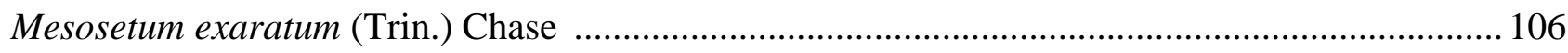

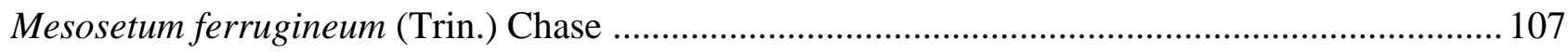

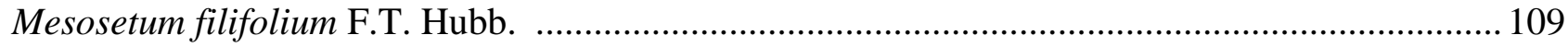

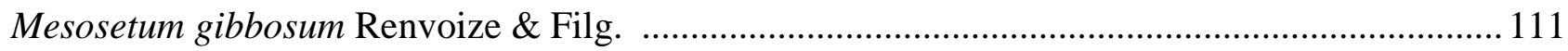

Mesosetum loliiforme (Hochst. ex Steud.) Chase .................................................................... 112

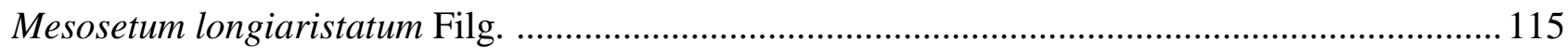

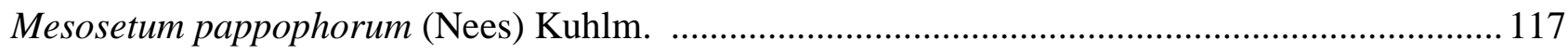

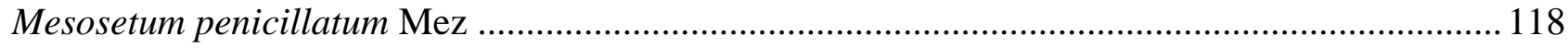

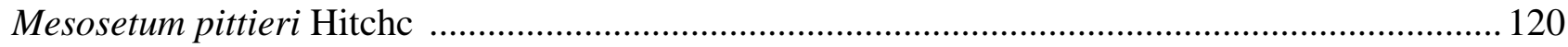

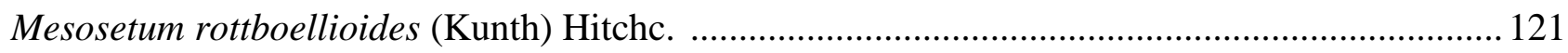

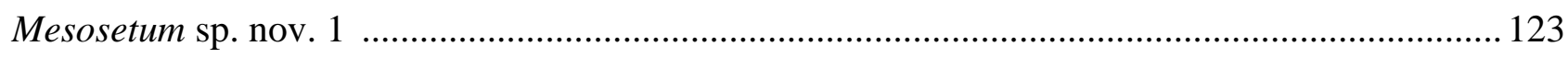

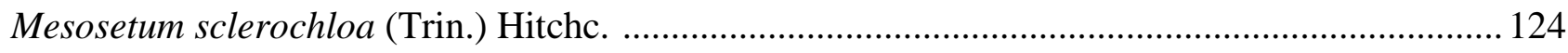

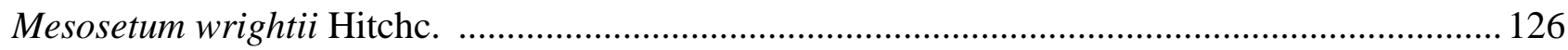

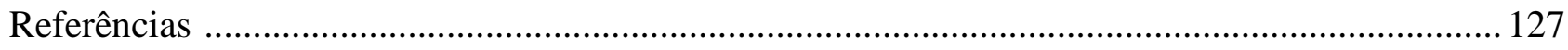

CAPÍTULO 3: A new species of Mesosetum Steud. (Poaceae, Paspaleae) from French Guiana .130

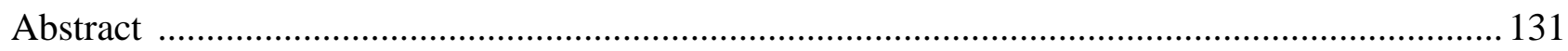

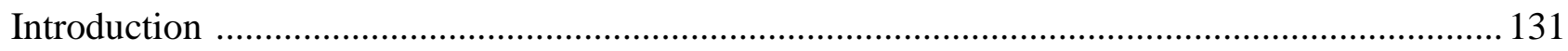




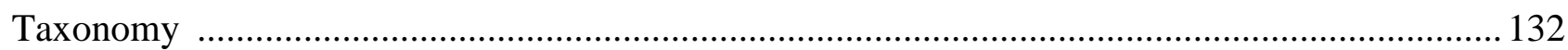

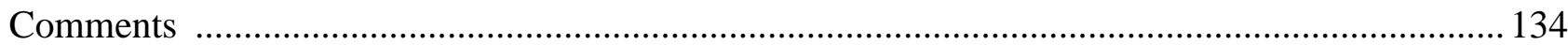

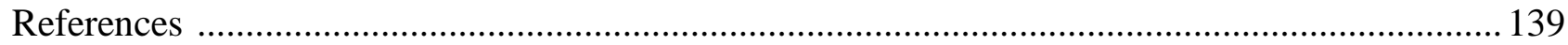

CAPÍTULO 4: Micromorphology of the upper anthecium in Mesosetum Steud. and related genera (Poaceae, Arthropogoninae) and its taxonomic applications ................................................ 141

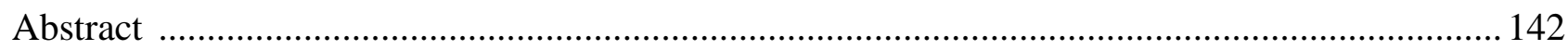

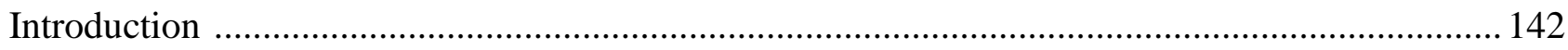

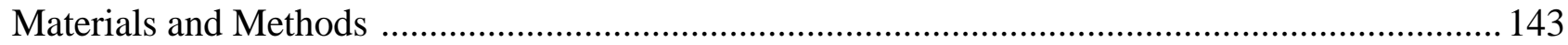

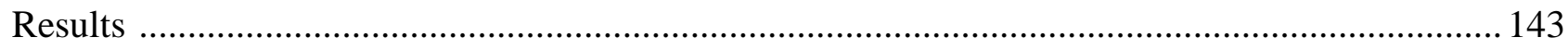

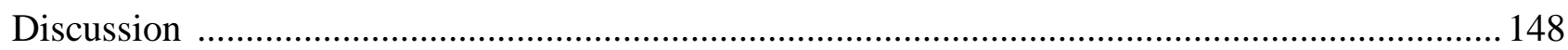

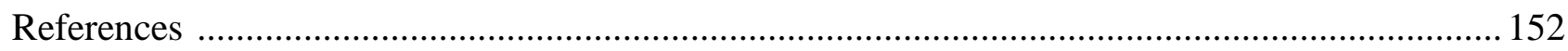

CAPÍTULO 5: Eleven new records of little known taxa of Mesosetum and Paspalum (Poaceae)

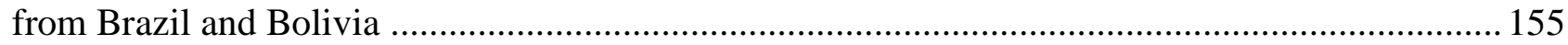

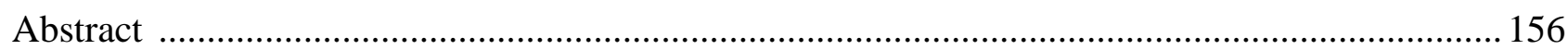

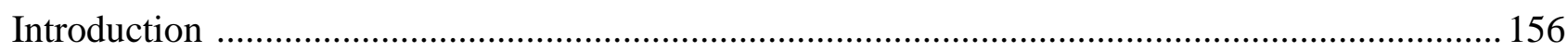

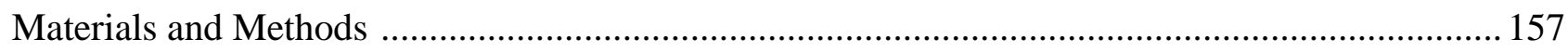

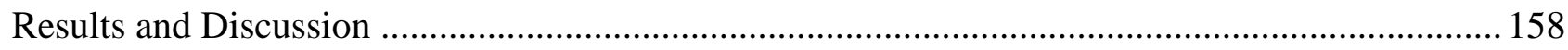

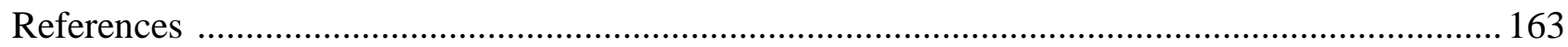

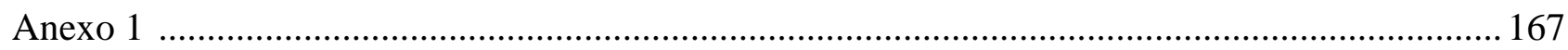

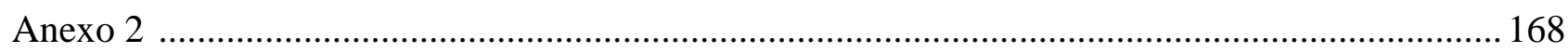

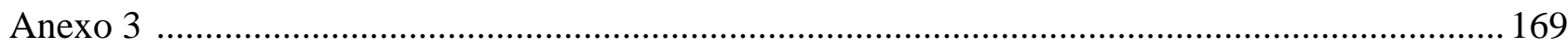




\section{Lista de Figuras}

\section{CAPÍTULO 1}

Figura 1. Árvore Bayesiana de consenso de maioria gerada a partir de uma matriz combinada de sequências plastidiais (matk, trnL, trnL-trnF, $p s b \mathrm{~A}-\operatorname{trn} \mathrm{H})$. Valores de PPbayes indicados acima dos ramos. 45

Figura 2. Árvore Bayesiana de consenso de maioria gerada a partir de uma matriz de sequências nucleares (ITS). Valores de PPbayes indicados acima dos ramos. 46

Figura 3. Árvore Bayesiana de consenso de maioria gerada a partir de uma matriz combinada de sequências plastidiais (matk, trnL, trnL-trnF, $p s b \mathrm{~A}-\operatorname{trn} \mathrm{H}$ ) e nuclear (ITS) combinadas. Valores de PPbayes indicados acima dos ramos. Valores de bootstrap indicados abaixo dos ramos. Números cromossômicos de acordo com a Tabela 1. 47

\section{CAPÍTULO 2}

Figura 1. Estados de carater: a-Mesosetum alatum Filg., pedicelos oblíquos voltados para a região mediana da ráquis (seta) e espiguetas inseridas obliquamente no pedicelo formando um calo com aparência geniculada (círculo), R.C. Oliveira 2765 (UB). b-M. bifarium (Hack.) Chase, ápice do pedicelo plano (seta) e espiguetas inseridas perpendicularmente no pedicelo (círculo), A.S. Silva 235 (UB). c-Mesosetum annuum Swallen, antécio papiloso e ápice acuminado, A.S. Silva 270 (UB). d-M. pappophorum (Nees) Kuhlm, antécio liso e ápice curvo, A.S. Silva 267 (UB). e-M. arenarium Swallen, ápice crestado-nervura central com uma expansão prolongada no dorso (seta), T.S. Filgueiras $1098(U B)$. 78

Figura 2. Fotos de espécies de Mesosetum: (a) detalhe da inflorescência de M. agropyroides Mez, J. Vidal III 129 (R); (b) detalhe da inflorescência de M. penicillatum Mez, T.S. Filgueiras et al. 3472 (SP); (c) detalhe da inflorescência de M. filifolium F.T. Hubb., P.L. Viana 3438 (SP); (d) detalhe da inflorescência de M. ansatum (Trin.) Kuhlm., R.C. Oliveira et al. 2766 (UB); (e) detalhe 
da inflorescência de M. loliiforme (Hochst. ex Steud.) Chase, A.R.O. Ribeiro 425 (UB); (f) espigueta de M. sclerochloa (Trin.) Hitchcock, A.S. Silva 266 (UB); (g) espigueta de M. comatum Swallen, A.R.O. Ribeiro 418 (UB); (h) detalhe da inflorescência de M. comatum, A.R.O. Ribeiro 418 (UB). (Foto: Silva et al. 2016). 82

Figura 3. Fotos de espécies de Mesosetum: (a) detalhe da inflorescência de M. alatum Filg., R.C. Oliveira et al. 2765 (UB); (b) detalhe da inflorescência de M. bifarium (Hack.) Chase, A.S. Silva et al. 235 (UB); (c) detalhe da inflorescência de M. chaseae Luces, R.C. Oliveira et al. 2772 (UB); (d) detalhe da inflorescência de M. compressum Swallen, Pinheiro \& Carvalho 438 (IAN); (e) detalhe da inflorescência de M. longiaristatum Filg., R.C. Oliveira et al. 2816 (UB); (f) detalhe da inflorescência de M. elytrochaetum (Hack.) Swallen, R.C. Oliveira et al. 2722 (UB); (g) detalhe da inflorescência de M. blakei Swallen, Stevens 8188 (K); (h) detalhe da inflorescência de $M$. pappophorum (Nees) Kuhlm., J.F.M. Valls 15949 (CEN). (Fotos b-f gentilmente cedidas por André R.O. Ribeiro). 84

Figura 4. Fotos de espécies de Mesosetum: (a) espigueta de M. arenarium Swallen, Burman 468 (SP); (b) espigueta de M. exaratum (Trin.) Chase, T. Sendulsky 443 (UB); (c) espigueta de $M$. filifolium F.T. Hubb., P.L. Viana et al. 3438 (IAN); (d) espigueta de M. gibbosum Swallen, Harley 50773 (HUEFS); (e) espigueta de M. pappophorum (Nees) Kuhlm., J.F.M. Valls et al. 15949 (CEN); (f) espigueta de M. arnacites (Trin.) A.S. Silva \& R.C. Oliveira, Hatchsbach 52312 (HUEFS). 96

Figura 5. Fotos de espécies de Mesosetum: (a) espigueta de M. cayennense Steud., vista ventral, vista dorsal, P.A. Reis et al. 181 (UB); (b) espigueta de M. rottboellioides (Kunth) Hitchc., vista ventral, vista dorsal, P.A. Reis et al. 331 (UB); (c) espigueta de M. ferrugineum (Trin.) Chase, R.C. Oliveira. et al. $2970(U B)$. 98 
Figure 1. Mesosetum sp. nov. (A) habit; (B) detail of rachis and pedicel; (C) spikelet - ventral view; (D) spikelet - lateral view; (E) detail of lower lemma - dorsal view; (F) upper anthecium - dorsal view; (G) anthecium - ventral view. Drawn by Darli Nuza from holotype in CAY. 135

Figure 2. Photos of Mesosetum sp.nov.1, J.J. de Granville, L. Aliker \& C. Sarthou 15423 (CAYparatype): (A) detail of inflorescence; (B) detail of rachis and pedicels. 136

Figure 3. Distribution map of Mesosetum sp. nov. 1 in the French Guiana. 137

\section{CAPÍTULO 4}

Figure 1 - a-g. Detail of the upper anthecium in some of the species analyzed. a. Mesosetum cayennense (R. Haase 630) - stomata (arrow). b. M. filifolium (R.R. Innes 19) - silica cells. c. M. pittieri (H. Pittier 4516) - papillae. d. M. filifolium (C.R. Martins 998) - bicellular microhairs (arrow). e. M. annuum (A.S. Silva et al. 270) - papillae. f. Tatianyx arnacites (W. Ganev 2728) papillae. g. M. chaseae (A. Pott et al 1771) - papillae. h. M. alatum (H. Jancoski et al. 444) unilobed germination lid. i. M. elytrochaetum (R. C. Oliveira et al. 2722) - bilobed germination lid. j. upper anthecium of M. loliiforme (T.W. Henkel 5820). 149

Figure 2 - UPGMA dendrogram based on Jaccard's similarity using micromorphological characters of the upper anthecium for Mesosetum, Tatianyx, and Keratochlaena species. *Bi. Mesosetum sect Bifaria. *Lo. Mesosetum sect Loliiformia. *Me. Mesosetum sect Mesosetum. *Pe. Mesosetum sect Penicillata. *Sc. Mesosetum sect Sclerochloae. *The classification of sections follows Filgueiras (1989). •. Group 1. A. Group 2. ロ. Group 3. ^. Subgroups corresponding exactly to sections proposed by Filgueiras (1989). 150

Figure 3 - PCA using micromorphological characters of the upper anthecium for Mesosetum, Tatianyx, and Keratochlaena species. •. Group 1. A. Group 2. ロ. Group 3. $\bullet$. Species not grouped.

Figure 4 - Apex of the upper anthecium in some of the species analyzed. a. Keratochlaena rigidifolia (J.F.M. Valls et al. 8432). b. Mesosetum annuum (A.S. Silva et al. 270). c. M. pittieri (H. 
Pittier 4516). d. Tatianyx arnacites (W. Ganev 2728). e. M. pappophorum (A.S. Silva et al. 267). f. M. cayennense (R. Haase 630). 152

\section{CAPÍTULO 5}

Figure 1 - Photos of Mesosetum species: (a) detail of inflorescence of M. agropyroides Mez, J. Vidal III 129; (b) detail of inflorescence of M. penicillatum Mez, T.S. Filgueiras et al. 3472; (c) detail of inflorescence of M. filifolium F.T. Hubb., P.L. Viana 3438; (d) detail of rachis of $M$. ansatum (Trin.) Kuhlm., R.C. Oliveira et al. 2766; (e) detail of inflorescence of M. loliiforme (Hochst. ex Steud.) Chase, A.R.O. Ribeiro 425; (f) spikelet of M. sclerochloa (Trin.) Hitchcock, A.S. Silva 266; (g) spikelet of M. comatum Swallen, A.R.O. Ribeiro 418; (h) detail of inflorescence of M. comatum, A.R.O. Ribeiro 418 . 159

Figure 2 - Photos of Paspalum species: (a) detail of inflorescence of P. burchellii Munro ex Oliv., J.R.I. Wood et al. 25784; (b) detail of inflorescence of P. lepton Schultes, J.R.I. Wood et al. 25733; (c) detail of inflorescence of P. trinitense (Mez) Denham, J.R.I. Wood et al. 26440. 161

Figure 3 - Distribution map with old and new records of Mesosetum and Paspalum species in Bolivia and Brazil: (a) Mesosetum agropyroides and M. loliiforme; (b) M. ansatum, M. filifolium, Paspalum burchellii and P. trinitense; (c) M. chaseae, M. comatum, M. penicillatum and $P$. phaeotrichum; (d) M. sclerochloa, P. lepton and P. oteroi. 162 


\section{Lista de Tabelas}

\section{CAPÍTULO 1.}

Tabela 1. Espécies, coletor e local de coletas de material botânico para análise filogenética. ASS = Anádria S. Silva. AROR = André R. O. Ribeiro. CEN = Herbário do Centro Nacional de Recursos Genéticos e Biotecnologia. DPS = Diogo P. Silva. ELE = E.L. Ekman. GD = G. Davidse. GHR = Gabriel H. Rua. K = Herbário Kew. MWSS = Mayco W. S. Sousa. PAR = Priscila A. Reis. RCO = Regina C. Oliveira. TSF $=$ Tarciso S. Filgueiras. UB = Herbário da Universidade de Brasília. $\mathrm{V}=$ José F. M. Valls. *DNA extraído de plantas herborizadas. **Número cromossômico registrado em outro acesso. .33

Tabela 2. Sequência e referência dos primers utilizados nas amplificações por PCR .41

CAPÍtULO 2. 61

Tabela 1. Carateres morfológicos úteis na distinção das espécies de Mesosetum Steud...... 67

CAPÍTULO 3

Table 1. Morphological differences between Mesosetum sp. nov. 1, M. cayennense and $M$. rottboellioides...

CAPÍTULO 4.

Table 1 - Specimens examined for micromorphological characters from upper anthecium.* According to Filgueiras (1989). 143

Table 2 - Micromorphological characters and character states of the upper anthecium of Mesosetum, Keratochlaena, and Tatianyx species used in the PCA and UPGMA analyses.

Table 3 - Data matrix used in the cluster analysis of Mesosetum and related genera. Character states according to Table 2 


\section{Taxonomia e filogenia do gênero Mesosetum Steud. (Poaceae, Paspaleae)}

\section{Resumo}

Mesosetum Steud. pertence à subfamília Panicoideae, tribo Paspaleae, subtribo Arthropogoninae. O gênero é Neotropical, com 25 espécies reconhecidas, que se distribuem desde o sul do México até o Nordeste da Argentina. O Brasil detém a maior riqueza de espécies do gênero, onde ocorrem 22 espécies, sendo 12 endêmicas. As espécies do gênero vêm sendo tradicionalmente incluídas em seções. Mesosetum pertence a um clado cujos membros possuem o número cromossômico básico $\mathrm{x}=10$, mas os primeiros relatos de contagens cromossômicas para o gênero citam $x=8$. Recentemente foi descoberto $x=4(2 n=8)$, além de espécies com $x=10(2 n=20$ e 2 $\mathrm{n}=60$ ). Mesosetum é caracterizado por apresentar inflorescências com um ramo racemiforme terminal, espiguetas com a primeira gluma adaxial à ráquis, gluma e/ou lema inferior com tufos de tricomas e cariopse com hilo linear. Todos esses caracteres são homoplásicos. O objetivo desta tese foi realizar um estudo filogenético para Mesosetum e seus gêneros relacionados, visando compreender as relações infragenéricas e a sua história evolutiva, e elaborar uma sinopse taxonômica baseada em informações dos conhecimentos disponíveis acerca do gênero e dados adicionais, incluindo novos caracteres taxonômicos e coletas. As inferências filogenéticas baseadas em marcadores plastidiais (matK, trnL, trnL-trnF, $p s b \mathrm{~A}-t r n \mathrm{H})$ e nuclear (ITS) corrobora o monofiletismo de Mesosetum, se Tatianyx for incluído dentro gênero. Além disso, mostram três principais linhagens evolutivas para as espécies de Mesosetum, suportadas por características citológicas e morfológicas. A sinopse foi elaborada com base em uma ampla revisão de herbários e em novas coletas botânicas e propõe uma nova descrição para o gênero Mesosetum, que inclui a ampliação da sua circunscrição, uma nova chave de identificação para espécies de Mesosetum, com a adição de novos caracteres e estados de caráter, comentários taxonômicos e ilustrações. Uma nova espécie de Mesosetum endêmica da Guiana Francesa é descrita. A importância da ornamentação do 
antécio superior, analisada com o uso de Microscopia Eletrônica de Varredura, foi demonstrada para a taxonomia do gênero e corroboram com os dados filogenéticos. Além disso, foram compilados dados de distribuição geográfica atualizados, com registros de novas ocorrências no Brasil e na Bolívia.

Palavras-Chave: Panicoideae, Arthropogoninae, Neotropical, marcadores moleculares, gramíneas. 


\section{Taxonomy and Phylogeny of the genus Mesosetum Steud. (Poaceae,}

\section{Paspaleae)}

\section{Abstract}

Mesosetum Steud. belongs to subfamily Panicoideae, tribe Paspaleae, subtribe Arthropogoninae. The genus is Neotropical, with 25 species that occur from South Mexico to Northeast of Argentina. Brazil is the centre of diversity with 22 species, which 12 are endemic to the country. Traditionally, species of this genus have been included in sections. The genus Mesosetum is related to a clade recognized based on their basic chromosome numbers $\mathrm{x}=10$. However, the first reports of chromosome numbers in Mesosetum cited $\mathrm{x}=8$. The basic chromosome numbers $x=4(2 n=8)$ and also $x=10(2 n=20$ and $2 n=60)$ have recently been reported. Mesosetum species are characterized by a raceme-like solitary terminal inflorescence, spikelets with the first glume adaxial to the rachis, the glume and lower lemma with tufts of hairs and the caryopsis with a linear hilum. All these characters are homoplasic. The aim of this thesis was to performe a phylogenetic study of Mesosetum, understanding the infrageneric relationships and the evolutionary history of the genus, and to elaborate taxonomic synopsis based on new data including the informations available to Mesosetum. Phylogenetic inferences based on plastid (matK, $\operatorname{trn} \mathrm{L}, \operatorname{trn} \mathrm{L}-\operatorname{trn} \mathrm{F}, p s b \mathrm{~A}-\operatorname{trn} \mathrm{H})$ and nuclear (ITS) markers corroborate the monophyly of Mesosetum if Tatianyx is included within the genus. Furthermore, it was showed three major evolutionary lineages within Mesosetum, supported by cytological and morphological characteristics. The synopsis was elaborated based on a review of herbaria and new botanical collections, propose a new description for the genus Mesosetum, which includes the new circumscription, a new identification key for Mesosetum species, with addition of new characters and character states, taxonomic comments, and illustrations. A new species of Mesosetum endemic to French Guiana is described. The importance of the ornamentation of the upper anthecium, analyzed with Scanning Electron 
Microscopy, was demonstrated for the taxonomy of the genus, and corroborates with the phylogenetic data. Moreover, updated geographic distribution data were compiled, and new records from Brazil and Bolivia were documented.

Key words: Panicoideae, Arthropogoninae, Neotropical, molecular markers, grasses. 


\section{Introdução Geral}

Na revisão taxonômica mais recente de Mesosetum Steud. (Filgueiras 1989), foram aceitas 25 espécies que se distribuem do sul do México ao Nordeste da Argentina. O Brasil apresenta a maior riqueza de táxons de Mesosetum, já que 22 espécies ocorrem no país e destas, 12 são endêmicas (Silva et al. 2016, Filgueiras et al. 2017). O Brasil Central é um importante centro de diversidade do gênero, onde ocorrem 16 espécies, sete das quais são endêmicas da região.

As espécies de Mesosetum são campestres, frequentes e algumas têm destaque pelo seu potencial forrageiro (Allem \& Valls 1987, Filgueiras 1989, Townsend et al. 2012). Entre elas, Mesosetum chaseae Luces vem se destacando como uma alternativa forrageira (Silva 2008, Costa et al. 2009, Silva et al. 2012, Meirelles et al. 2015).

Mesosetum é caracterizado por apresentar um ramo florífero racemiforme terminal, espiguetas com a primeira gluma adaxial à ráquis, gluma e/ou lema inferior com tufos de tricomas e cariopse com hilo linear (Filgueiras 1986, 1989).

Há divergência, entre os autores, quanto à delimitação de espécies e à subdivisão infragenérica de Mesosetum. Chase (1911) propôs Mesosetum sect. Mesosetum e M. sect. Bifaria (Hack.) Chase. Mais tarde, Swallen (1937) aceitou 33 espécies e acrescentou às seções propostas por Chase (1911), outras quatro: M. sect. Annua Swallen, M. sect. Penicillata Swallen, M. sect. Loliiformia Swallen e M. sect. Sclerochloae Swallen. As espécies de M. sect. Mesosetum foram transferidas para $M$. sect. Fulva Swallen. Pilger (1940) aceitou parcialmente o trabalho de Swallen, reconheceu 30 espécies e apenas três seções: $M$. sect. Bifaria, $M$. sect. Eumesosetum Pilg. e M. sect. Sclerochloae. Filgueiras $(1986,1989)$ reconheceu 25 espécies e as distribuiu em cinco seções, $M$. sect. Annua foi incluída em M. sect. Loliiformia, e M. sect. Fulva, por conter a espécie tipo do gênero, teve o nome corrigido para $M$. sect. Mesosetum. O estabelecimento das seções por Filgueiras (1989) foi baseado em uma argumentação fundamentada, mas de cunho gradista. 
Análises filogenéticas da tribo Paniceae s.l. (Giussani et al. 2001, Morrone et al. 2012) mostram que Mesosetum pertence a um clado cujos membros compartilham o número cromossômico básico x = 10. Nessas análises, Mesosetum apresenta-se como grupo irmão dos gêneros monoespecíficos Tatianyx Zuloaga \& Soderstr. e Keratochlaena Morrone, no clado denominado Arthropogoninae, constituído por 16 gêneros americanos. Apenas três gêneros de Arthropogoninae não ocorrem no Brasil e Tatianyx e Keratochlaena são endêmicos do país (Zuloaga \& Soderstrom 1985, Filgueiras 2017, Shirasuna et al. 2017).

Embora Mesosetum esteja num clado cujo número básico é $\mathrm{x}=10$, os primeiros relatos de contagens cromossômicas para o gênero mostram número básico x = 8. Gould (1966), Pohl \& Davidse (1971) e Davidse \& Pohl (1972) realizaram contagens em M. pittieri Hitchc. Gould \& Soderstrom (1967) e Sede et al. (2010) em M. loliiforme (Hochst. ex Steud.) Chase. Watson \& Dallwitz (1992), Silva et al. (2009, 2012) realizaram contagens em M. chaseae Luces. Todas as contagens relataram $2 \mathrm{n}=16$ cromossomos.

Ribeiro (2013) estudou espécies da seção Bifaria de Mesosetum e relatou dois novos números cromossômicos para o gênero: $2 \mathrm{n}=24$ para $M$. chaseae e M. elytrochaetum (Hack.) Swallen e 2n = 8 para M. alatum Filg. e M. ansatum (Trin.) Kuhlm. Para M. longiaristatum Filg. foram registrados dois citótipos: $2 \mathrm{n}=8$ e $2 \mathrm{n}=24$ cromossomos.

Os resultados de Sousa (2014) para espécies da seção Mesosetum ampliam e dificultam a compreensão da evolução das linhagens do gênero, já que encontrou 2n = 20 cromossomos para $M$. cayennense Steud. e $M$. rottboellioides (Kunth) Hitchc., e $2 \mathrm{n}=60$ cromossomos para $M$. ferrugineum (Trin.) Chase.

Ribeiro et al. (2015) confirmaram a ocorrência de um novo número cromossômico básico x = 4 em Mesosetum, acrescentando desafios à interpretação da evolução do grupo.

O presente estudo teve como objetivo primordial testar o monofiletismo de Mesosetum e avaliar as relações infragenéricas das espécies através de hipóteses filogenéticas, com o intuito de reconstruir a história evolutiva, e auxiliar na compreensão da variação cromossômica do grupo. 
A filogenia molecular (Capítulo 1) foi baseada nos marcadores matK, $\operatorname{trn} \mathrm{L}, \operatorname{trn} \mathrm{L}-\operatorname{trn} \mathrm{F}, p s b \mathrm{~A}$ trnH e ITS, regiões frequentemente utilizadas em análises filogenéticas de Panicoideae (González \& Morton 2005, Rua et al. 2010, Teerawatananon et al. 2012, Scataglini et al. 2014, Silva et al. 2015a). É amplamente difundido que os marcadores plastidiais, por serem muito conservados, podem ser pouco úteis para análises filogenéticas de grupos com especiação mais recente, e os de núcleo podem ser influenciados pela ocorrência de poliploidia. Para minimizar as limitações de cada grupo de marcadores, ambos foram utilizados na análise.

O trabalho intenso de coleta e a revisão minuciosa de diversos herbários do Brasil e exterior permitiram a ampliação da área de ocorrência conhecida das espécies, bem como ampliaram a compreensão da variação morfológica dos táxons. Esses resultados foram organizados na forma de uma sinopse taxonômica (Capítulo 2), que traz uma nova chave de identificação, atualizando a aprimorada revisão do gênero (Filgueiras 1989).

Uma nova espécie de Mesosetum é formalmente descrita para a Guiana Francesa no Capítulo 3.

No Capítulo 4, apresentamos o artigo em que analisamos o valor taxonômico da ornamentação do antécio superior em Microscópio Eletrônico de Varredura (MEV). A ornamentação do antécio superior foi utilizado na argumentação da distinção de gêneros de Arthropogoninae, mas permanecia inexplorado em Mesosetum (Silva et al. 2015b).

A ampliação da área de ocorrência de seis táxons de Mesosetum, que são comentados no Capítulo 2, somada a informações sobre grau de ameaça e comentários taxonômicos, foram publicado no artigo apresentado no Capítulo 5 (Silva et al. 2016). 


\section{Referências}

Aliscioni, S.S., Giussani, L.M., Zuloaga, F.O. \& Kellogg, E.A. (2003) A molecular phylogeny of Panicum (Poaceae: Paniceae): tests of monophyly and phylogenetic placement within the Panicoideae. American Journal of Botany 90: 796-821.

Allem, A.C. \& Valls, J.F.M. (1987) Recursos forrageiros nativos do pantanal Matogrossense, Documentos 8. Embrapa/DID, Embrapa/Cenargen, Brasília-DF, 339 pp.

Chase, M.A. (1911) Notes on genera of Paniceae IV. Proceedings of the Biological Society of Washington 24: 103-160.

Costa, N.L., Gianluppi, V., Bendahan, A.B., Braga, R.M. \& Mattos, P.S.R. (2009) Produção de Forragem e Morfogênese de Mesosetum chaseae Luces em Diferentes Idades de Corte. Boletim de Pesquisa e Desenvolvimento, 09. Embrapa Roraima, Boa Vista-RR, 15 pp.

Davidse, G. \& Pohl, R.W. (1972) Chromosome numbers, meiotic behavior, and notes on some grasses from Central America and the West Indies. Canadian Journal of Botany 50: 14411452.

Filgueiras, T.S. (1986) O gênero Mesosetum Steudel (Gramineae: Paniceae). Tese de Doutorado. Universidade Estadual de Campinas, Campinas, 344 pp.

Filgueiras, T.S. (1989) Revisão de Mesosetum Steudel (Gramineae: Paniceae). Acta Amazônica 19: $47-114$.

Filgueiras, T.S. (2017) Keratochlaena in Lista de Espécies da Flora do Brasil. Jardim Botânico do Rio de Janeiro. Disponível em:

<http://floradobrasil.jbrj.gov.br/jabot/floradobrasil/FB117294>. Acesso em: 20 Jan. 2017.

Filgueiras, T.S., Silva, A.S. \& Oliveira, R.C. de. (2017) Mesosetum in Lista de Espécies da Flora do Brasil. Jardim Botânico do Rio de Janeiro. Disponível em: <http://floradobrasil.jbrj.gov.br/jabot/floradobra.sil/FB13355>. Acesso em: 20 Jan. 2017 
Giussani, L.M., Cota-Sanchez, H., Zuloaga F.O. \& Kellogg, E.A. (2001) A molecular phylogeny of the grass subfamily Panicoideae (Poaceae) shows multiple origins of C4 photosynthesis. American Journal of Botany 88:1993-2012.

González, A.M.T. \& Morton, C.M. (2005) Molecular and morphological phylogenetic analysis of Brachiaria and Urochloa (Poaceae). Molecular Phylogenetics and Evolution 37: 36-44.

Gould, F.W. (1966) Chromosome numbers of some Mexican grasses. Canadian Journal of Botany 44: $1683-1696$.

Gould, F.W. \& Soderstrom, T.R. (1967) Chromosome numbers of tropical American grasses. American Journal of Botany 54: 676-683.

Grass Phylogeny Working Group (GPWG). (2011) New grass phylogeny resolves deep evolutionary relationships and discovers $\mathrm{C}_{4}$ origins. New Phytologist 193: 304-312.

Ibrahim, D.G., Burke, T., Ripley, B.S. \& Osborne, C.P. (2009) A molecular phylogeny of the genus Alloteropsis (Panicoideae, Poaceae) suggests an evolutionary reversion from $\mathrm{C} 4$ to $\mathrm{C} 3$ photosynthesis. Annals of Botany 103: 127-136.

Meirelles, A.C.S., Monteiro, E.R., Silva, L.A.C., Silva, D., Santos, S.A., Oliveira-Collet, S.A., Mangolin, C.A. \& Machado, M.F.P.S. (2015) Esterase polymorphism for genetic diversity analysis of some accessions of a native forage grass, Mesosetum chaseae Luces, from the Brazilian Pantanal. Tropical Grasslands 3: 194-204.

Morrone, O., Aagesen, L., Scataglini, M.A., Salariato, D.L., Denham, S., Chemisquy, M.A., Sede, S.M., Giussani, L.M., Kellogg, E.A. \& Zuloaga, F.O. (2012) Phylogeny of the Paniceae (Poaceae: Panicoideae): integrating plastid DNA sequences and morphology into a new classification. Cladistics: 1-24.

Pilger, R. (1940) Gramineae. In Engler, A \& Prantl, K. (Ed.) Die Natürlichen Pflanzenfamilen, Leipzig., Wilhelm Engelmann 2 ed., 208 pp.

Pohl, R.W. \& Davidse, G. (1971) Chromosome numbers of Costa Rican grasses. Brittonia 23: 293324. 
Ribeiro, A.R.O. (2013) Citogenética, reprodução e variabilidade morfológica de espécies de Mesosetum sect. Bifaria (Hack.) Chase (Poaceae: Paspaleae). Dissertação de Mestrado.Universidade de Brasília, Brasília-DF, 111 pp.

Ribeiro, A.R.O., Sousa, M.W.S., Oliveira, R.C., Araujo, A.C.G., Fagg, C.W. \& Pozzobon, M.T. (2015) Cytological studies in four species of Mesosetum (Arthropogoninae) reveal the lowest chromosome number among the Neotropical Poaceae. Plant Systematics and Evolution 301: 2377-2386.

Rua, G.H., Speranza, P.R., Vaio, M. \& Arakaki, M. (2010) A phylogenetic analysis of the genus Paspalum (Poaceae) based on cpDNA and morphology. Plant Systematic and Evolution 288: $227-243$.

Sánchez-Ken, J.G. \& Clark, L.G. (2010) Phylogeny and a new tribal classification of the Panicoideae s.l. (Poaceae) based on plastid and nuclear sequence data and structural data. American Journal of Botany 97: 1732-1748.

Scataglini, M.A., Zuloaga, F.O., Giussani, L.M., Denham, S.S. \& O. Morrone. (2014) Phylogeny of New World Paspalum (Poaceae, Panicoideae, Paspaleae) based on plastid and nuclear markers. Plant Systematic and Evolution 300:1051-1070.

Sede, S., Escobar, A., Morrone, O. \& Zuloaga, F.O. (2010) Chromosome studies in American Paniceae (Poaceae-Panicoideae). Annals of the Missouri Botanical Garden 97: 128-138.

Shirasuna, R.T., Silva, A.S. \& Oliveira, R.C. (2017) Tatianyx in Lista de Espécies da Flora do Brasil. Jardim Botânico do Rio de Janeiro. Disponível em:

<http://floradobrasil.jbrj.gov.br/jabot/floradobrasil/FB20506>. Acesso em: 20 Jan. 2017.

Silva, A.C.S. (2008) Qualidade de sementes da grama-do-cerrado (Mesosetum chaseae Luces) na sub-região da Nhecolândia, Pantanal, MS. Dissertação de Mestrado, Universidade Estadual Paulista, Botucatu-SP, 55 pp.

Silva, L.A.C., Pagliarini, M.S., Santos, S.A., Valle, C.B. \& Junk, L. (2009) Determinação do número cromossômico e microsporogênese de populações naturais de Mesosetum chaseae 
Luces, gramínea nativa do Pantanal, Brasil. In Anais do Simpósio Internacional de Melhoramento de Forrageiras 2, Campo Grande-MS. CD-ROM.

Silva, L.A.C., Pagliarini, M.S., Santos, S.A., Silva, N. \& Souza, V.F. (2012) Chromosome number, microsporogenesis, microgametogenesis, and pollen viability in the Brazilian native grass Mesosetum chaseae (Poaceae). Genetics and Molecular Research 11: 4100-4109.

Silva, C., Snak, C., Schnadelbach, A.S., van den Berg, C. \& Oliveira, R.P. (2015a) Phylogenetic relationships of Echinolaena and Ichnanthus within Panicoideae (Poaceae) reveal two new genera of tropical grasses. Molecular Phylogenetics and Evolution 93: 212-233.

Silva, A.S, Ribeiro, A.R.O., Sousa, M.W.S., Fagg, C.W., Falcão, R. \& Oliveira, R.C. (2015b) Micromorphology of the upper anthecium in Mesosetum Steud. and related genera (Poaceae, Arthropogoninae) and its taxonomic applications. Rodriguésia 66(2): 645-657.

Silva, A.S, Villarroel, D., Ribeiro, A.R.O.\& Oliveira, R.C. (2016) Eleven new records of little known taxa of Mesosetum and Paspalum (Poaceae) from Brazil and Bolivia. Phytotaxa 268 (1): 069-079.

Sousa, M.W.S. (2014) Citogenética e morfologia de espécies de Mesosetum Steud. (Poaceae, Paspaleae). Dissertação de Mestrado.Universidade de Brasília, Brasília-DF. 76 pp.

Swallen, J.R. (1937) The grass genus Mesosetum. Brittonia 2: 363-392.

Teerawatananon, A., Jacobs, S.W.L. \& Hodkinson, T.R. (2012) Phylogenetics of Panicoideae (Poaceae) Based on Chloroplast and Nuclear DNA Sequences. Telopea 13:115-142.

Townsend, C.R., Costa, N.L. \& Pereira, R.G.A. (2012) Pastagens Nativas na Amazônia Brasileira, Documentos 149. Embrapa, Porto Velho, 25 pp.

Watson, L. \& Dallwitz, M.J. (1992) The grass genera of the world. C.A.B. International, Wallingford, $1038 \mathrm{pp}$.

Zuloaga, F.0. \& Soderstrom, T.R. (1985) Classification of the Outlying Species of New World Panicum (Poaceae: Paniceae). Smithsonian Contributions to Botany 59: 1-63. 
Capítulo 1

Filogenia de Mesosetum Steud. (Poaceae, Paspaleae) baseada em marcadores plastidiais e nuclear 


\section{Capítulo 1}

Filogenia de Mesosetum Steud. (Poaceae, Paspaleae) baseada em marcadores plastidiais e nuclear

\section{Introdução}

Paniceae lato sensu é uma das maiores tribos de Panicoideae, inclui gêneros que apresentam grande diversidade morfológica, citológica e fisiológica, estando disponíveis vários estudos que comprovam o seu parafiletismo (Gómez-Martínez \& Culham 2000, Duvall et al. 2001, SánchezKen \& Clark 2010, Morrone et al. 2012). Morrone et al. (2012) formalizaram a subdivisão de Paniceae s.l. em duas tribos: Paspaleae J. Presl, que engloba os gêneros americanos com número cromossômico básico $\mathrm{x}=10$ e Paniceae s.s. para os gêneros pantropicais com $\mathrm{x}=9$. Neste trabalho, Mesosetum é incluído na tribo Paspaleae, subtribo Arthropogoninae Butzin.

A representatividade do gênero Mesosetum nas análises filogenéticas disponíveis é limitada a uma ou duas espécies (Gomez-Martinez \& Culham 2000, Duvall et al. 2001, Giussani et al. 2001, GPWG 2011, Morrone et al. 2012) ou o gênero não é representado. Nessas análises, sugere-se o gênero como monofilético. No entanto, as relações entre Mesosetum e seus gêneros relacionados diferem nesses estudos.

Na análise cladística preliminar proposta para a tribo Paniceae por Zuloaga et al. (2000) baseada em morfologia, Mesosetum aparece como grupo irmão dos gêneros Chaetium Nees, Tatianyx Zuloaga \& Soderstr. e Spheneria Kuhlm. Este clado tem como sinapomorfia o pedicelo com ápice oblíquo, caráter que se aplica a poucas espécies de Mesosetum.

Gómez-Martinez \& Culham (2000) propuseram uma análise filogenética para a subfamília Panicoideae a partir do espaçador plastidial trnL-F, com ênfase na tribo Paniceae, e Mesosetum foi relacionado ao clado de Leptocoryphium Nees com as espécies Panicum laxum Sw. e $P$. 
polygonatum Schrad. - atualmente ambas as espécies são reconhecidas como Steichisma laxum (Sw.) Zuloaga - compondo o clado "American Paniceae" com os gêneros Paspalum L., Axonopus P. Beauv., Ichnanthus P. Beauv. e a espécie Panicum obtusum Kunth. Esta última espécie foi posteriormente transferida para o gênero monoespecífico Hopia Zuloaga \& Morrone, sob H. obtusa (Kunth) Zuloaga \& Morrone (Zuloaga et al. 2007). Não há uma sinapomorfia óbvia para o clado, no entanto os táxons compartilham o número cromossômico básico x=10, com exceção de Mesosetum, com x = 8 (Gómez-Martinez \& Culham 2000).

Na filogenia proposta para a subfamília Panicoideae por Giussani et al. (2001), baseada no gene $n d h F$, o clado no qual Mesosetum foi relacionado recebeu o nome "ambiguous clade", uma vez que seus membros compartilham poucas características morfológicas, anatômicas, fisiológicas e ecológicas. O trabalho de Giussani et al. (2001) foi o primeiro a relatar a proximidade evolutiva entre os membros do "ambiguous clade". Neste mesmo ano, Duvall et al. (2001) apresentaram uma filogenia molecular (baseada no gene rpoC2) para a tribo Paniceae e, assim como em Giussani et al. (2001), Mesosetum apresentou uma forte relação com Tatianyx, sendo esses gêneros relacionados a Altoparadisium Filg., Davidse, Zuloaga \& Morrone e Streptostachys Desv. No entanto, Artrhopogon Nees e Panicum prionitis Nees - atualmente Coleataenia prionitis (Nees) Soreng membros do "ambiguous clade", foram relacionados a outro clado (Duvall et al. 2001).

Aliscioni et al. (2003) propuseram uma filogenia molecular (baseada no gene $n d h \mathrm{~F}$ ) para o gênero Panicum, na qual incluíram alguns membros do "ambiguous clade” de Giussani et al. (2001) como parte do grupo externo e novamente os integrantes desse clado mostraram-se relacionados. Os autores comentam que as relações filogenéticas do "ambiguous clade" não são claras e este representa um “enigma” a ser elucidado. O que também foi comentado pelo GPWG (2011).

$\mathrm{Na}$ mais recente proposta filogenética da tribo Paniceae (Morrone et al. 2012), o "ambiguous clade" foi formalmente reconhecido como a subtribo Arthropogoninae, dentro da tribo Paspaleae, composta por 16 gêneros americanos. No entanto, as relações filogenéticas entre os gêneros pertencentes a essa subtribo ainda não estão claras. Nesta análise, o clado Arthropogoninae 
é razoavelmente suportado quando analisado apenas pelo gene $n d h \mathrm{~F}$ (jacknife $=73 \%$ ), com apenas três sinapomorfias moleculares que definem o grupo e fracamente suportado nas análises combinadas de $n d h \mathrm{~F}$ com caracteres morfológicos (jacknife $=54 \%$ ). Não há uma sinapomorfia morfológica conhecida para o clado.

Os gêneros do clado Arthropogoninae são heterogêneos quanto aos caracteres morfológicos, anatômicos e fisiológicos (Morrone et al. 2012).

Gêneros da subtribo Arthropogoninae já foram associados a outros grupos, às vezes, pouco relacionados filogeneticamente: Streptostachys Desv., Oplismenopsis Parodi, Homolepis Chase, Mesosetum, Triscenia Griseb. e Tatianyx eram relacionados à subtribo Setariinae (Clayton \& Renvoize 1986); Apochloa Zuloaga \& Morrone, Coleataenia Griseb., Cyphonanthus Zuloaga \& Morrone e Stephostachys Zuloaga \& Morrone foram segregados de Panicum L. (Morrone et al. 2007, Sede et al. 2008, Zuloaga et al. 2010), e Keratochlaena e Oncorachis foram segregados de Streptostachys (Sede et al. 2009, Morrone \& Zuloaga 2009).

Dentro de Arthropogoninae, o clado composto pelos gêneros Keratochlaena, Mesosetum e Tatianyx é bem suportado (jacknife $=99 \%$ ) por 10 substituições de nucleotídeos e presença de hilo linear. No entanto, a presença de hilo linear é um estado de caráter homoplásico (Morrone \& Zuloaga 1991, Morrone et al. 2012).

Como as relações entre os gêneros da subtribo Arthropogoninae são pouco claras, novos estudos filogenéticos são essenciais para o entendimento da história evolutiva da subtribo. O fato do clado ser Americano, com centro de diversidade no Brasil, e com gêneros e espécies pouco conhecidos, estimulou-nos a trabalhar para a compreensão da história evolutiva do grupo. Mesosetum é o maior gênero da subtribo, com 25 espécies de importância na composição dos campos naturais, especialmente do Brasil Central e destaca-se pelo seu potencial forrageiro (Filgueiras 1989, Townsend et al. 2012, Silva et al. 2012, Meirelles et al. 2015).

Embora Mesosetum esteja aparentemente bem circunscrito, há evidências morfológicas e citológicas de que o gênero tem grupos de espécies com histórico evolutivo distinto. As espécies do 
gênero vêm sendo tradicionalmente incluídas em seções (Swallen 1937, Filgueiras 1989). A seção Bifaria já foi reconhecida como gênero (Kuntze 1898), por agrupar espécies com glumas inferiores aristadas ou mucronadas, e neste grupo há espécies com $2 n=8,2 n=16$ e $2 n=24$ cromossomos (Ribeiro 2013, Ribeiro et al. 2015). Na seção Mesosetum há registros de espécies com 2n = 20 e 2n = 60 cromossomos (Sousa 2014), único grupo com espécies que apresentam tricomas castanhos a ferrugíneos nas espiguetas.

O objetivo deste capítulo foi testar a monofilia de Mesosetum e das seções relacionadas e investigar a sua relação com outros gêneros de Arthropogoninae. Foram usadas análises de Máxima Parcimônia, Máxima Verossimilhança e Inferência Bayesiana em sequências de DNA de regiões plastidiais (mat $\mathrm{K}, \operatorname{trn} \mathrm{L}, \operatorname{trn} \mathrm{L}-t r n \mathrm{~F}, p s b \mathrm{~A}-t r n \mathrm{H})$ e nuclear (ITS). 


\section{Metodologia}

- Amostragem

Foram realizadas expedições de coleta de material botânico de espécies do gênero Mesosetum e dos grupos externos. As exsicatas foram depositadas no herbário UB (acrônimo em Thiers, continuously updated) e duplicatas distribuídas a herbários congêneres. Associado aos vouchers de herbário foram obtidas amostras em sílica e mudas que estão mantidas em cultivo em telado da Universidade de Brasília (UnB).

Foram sequenciados 72 espécimes, sendo 57 espécimes de Mesosetum, representando os 25 táxons atualmente reconhecidos no gênero, 11 espécimes dos demais clados de Arthropogoninae, 2 espécimes de Paspalinae e 2 espécimes de Otachyriinae referidos por Morrone et al. (2012) para compor o grupo externo (Tabela 1).

Para as espécies que não ocorrem no Brasil e as que não foram encontradas em campo, o DNA foi extraído a partir de amostras de herbário (Tabela 1).

Espécies amplamente distribuídas e com mais de um número cromossômico conhecido contaram com múltiplos acessos de modo a avaliar o monofiletismo do táxon.

O estudo molecular foi desenvolvido no Laboratório de Genética Vegetal da Embrapa/Cenargen (Centro Nacional de Pesquisa de Recursos Genéticos e Biotecnologia). 
Tabela 1. Espécies, coletor e local de coletas de material botânico para análise filogenética. ASS = Anádria S. Silva. AROR = André R. O. Ribeiro. CEN = Herbário do Centro Nacional de Recursos Genéticos e Biotecnologia. DPS = Diogo P. Silva. ELE = E.L. Ekman. GD = G. Davidse. GHR = Gabriel H. Rua. K = Herbário Kew. MWSS = Mayco W. S. Sousa. PAR = Priscila A. Reis. RCO = Regina C. Oliveira. TSF = Tarciso S. Filgueiras. UB = Herbário da Universidade de Brasília. V = José F. M. Valls. *DNA extraído de plantas herborizadas. **Número cromossômico registrado em outro acesso.

\begin{tabular}{|c|c|c|c|c|c|}
\hline Espécie & Coletor e $\mathbf{n}^{\circ}$ & Local de coleta & $\begin{array}{l}\text { Seção (Filgueiras } \\
\text { 1989) }\end{array}$ & 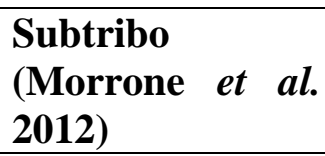 & $\begin{array}{l}\text { Número } \\
\text { cromossômico }\end{array}$ \\
\hline \multicolumn{6}{|l|}{ Grupo interno } \\
\hline Mesosetum agropyroides $\mathrm{Mez}$ & Glaziou s.n. $(\mathrm{K})^{*}$ & Brasil, Goiás. & Penicillata & Arthropogoninae & - \\
\hline Mesosetum alatum Filg. & RCO 2765 (UB) & $\begin{array}{l}\text { Brasil, Mato } \\
\text { Grosso, Água } \\
\text { Boa. }\end{array}$ & Bifaria & Arthropogoninae & $\begin{array}{l}2 \mathrm{n}=8 \text { (Ribeiro } \\
2016)\end{array}$ \\
\hline \multirow[t]{2}{*}{ Mesosetum annuиm Swallen } & ASS 270 (UB) & $\begin{array}{l}\text { Brasil, Goiás, } \\
\text { Flores de Goiás. }\end{array}$ & Loliiformia & Arthropogoninae & $\begin{array}{l}2 \mathrm{n}=8^{* *} \text { (Sousa } \\
2014 \text {, Ribeiro et } \\
\text { al. 2015) }\end{array}$ \\
\hline & $\begin{array}{l}\text { PAR } 182(\mathrm{UB}) \\
\text { RCO } 2819(\mathrm{UB})\end{array}$ & $\begin{array}{l}\text { Brasil, Goiás, } \\
\text { Flores de Goiás. } \\
\text { Brasil, Tocantins, } \\
\text { Arraias. }\end{array}$ & & & \\
\hline Mesosetum ansatum (Trin.) Chase & $\begin{array}{l}\text { RCO } 2766 \text { (UB) } \\
\text { RCO } 2784(\mathrm{UB})\end{array}$ & $\begin{array}{l}\text { Brasil, Mato } \\
\text { Grosso, Poconé. } \\
\text { Brasil, Mato } \\
\text { Grosso, Chapada } \\
\text { dos Guimarães. }\end{array}$ & Bifaria & Arthropogoninae & $\begin{array}{l}2 \mathrm{n}=8 \text { (Ribeiro } \\
2016)\end{array}$ \\
\hline Mesosetum arenarium Swallen & TSF $1098(\mathrm{UB}) *$ & $\begin{array}{l}\text { Brasil, Minas } \\
\text { Gerais, } \\
\text { Diamantina. }\end{array}$ & Loliiformia & Arthropogoninae & - \\
\hline Mesosetum bifarium (Hack.) Chase & ASS 235 (UB) & Brasil, Goiás, & Bifaria & Arthropogoninae & $2 \mathrm{n}=16$ (Ribeiro \\
\hline
\end{tabular}




\begin{tabular}{|c|c|c|c|c|c|}
\hline Espécie & Coletor e $\mathbf{n}^{\circ}$ & Local de coleta & $\begin{array}{l}\text { Seção (Filgueiras } \\
\text { 1989) }\end{array}$ & $\begin{array}{l}\text { Subtribo } \\
\text { (Morrone et al. } \\
\text { 2012) }\end{array}$ & $\begin{array}{l}\text { Número } \\
\text { cromossômico }\end{array}$ \\
\hline & & Teresina de Goiás. & & & 2016) \\
\hline & AROR 391 (UB) & Brasil, Goiás, Alto & & & $2 \mathrm{n}=16$ (Ribeiro \\
\hline & & Paraíso. & & & 2016) \\
\hline & V 15927 (CEN) & Brasil, Goiás, & & & $2 \mathrm{n}=8$ (Ribeiro \\
\hline & & Flores de Goiás. & & & 2016) \\
\hline & V 15933 (CEN) & Brasil, Goiás, & & & $2 \mathrm{n}=8$ (Ribeiro \\
\hline & & Flores de Goiás. & & & 2016) \\
\hline Mesosetum blakei Swallen & GD $20316(\mathrm{~K})^{*}$ & México, Tabasco, & Penicillata & Arthropogoninae & - \\
\hline & & Villa Hermosa & & & \\
\hline & & Escárcega. & & & \\
\hline Mesosetum cayennense Steud. & GHR 940 (UB) & $\begin{array}{l}\text { Brasil, Goiás, } \\
\text { Mineiros. }\end{array}$ & Mesosetum & Arthropogoninae & $\begin{array}{l}2 \mathrm{n}=20 \text { (Sousa } \\
2014)\end{array}$ \\
\hline & PAR $181(\mathrm{UB})$ & Brasil, Goiás, & & & $2 n=20$ (Ribeiro \\
\hline & & Flores de Goiás. & & & 2016) \\
\hline & RCO 2744 (UB) & Brasil, Goiás, Alto & & & \\
\hline & & Paraíso de Goiás. & & & \\
\hline & RCO 2848 (UB) & Brasil, Tocantins, & & & $2 \mathrm{n}=20$ (Ribeiro \\
\hline & & Natividade. & & & 2016) \\
\hline & RCO 2974 (UB) & Bolivia, Santa & & & \\
\hline & & Cruz, Chiquitos. & & & \\
\hline & V 15922 (CEN) & $\begin{array}{l}\text { Brasil, Goiás, } \\
\text { Flores de Goiás. }\end{array}$ & & & \\
\hline & V 15934 (CEN) & Brasil, Goiás, & & & \\
\hline Mesosetum chaseae Luces & RCO 2772 (UB) & $\begin{array}{l}\text { Brasil, Mato } \\
\text { Grosso Poconé }\end{array}$ & Bifaria & Arthropogoninae & $\begin{array}{l}2 n=24 \text { (Ribeiro } \\
2013 \text { ) }\end{array}$ \\
\hline & RCO 2981 (UB) & Bolivia, Santa & & & $2 \mathrm{n}=16^{* *}($ Silva \\
\hline & & Cruz, Roboré. & & & et al. 2012) \\
\hline Mesosetum chlorostachyum (Döll) Chase & RCO 3033 (UB) & $\begin{array}{l}\text { Brasil, Amazonas, } \\
\text { Careiro da Várzea. }\end{array}$ & Loliiformia & Arthropogoninae & $\begin{array}{l}2 \mathrm{n}=8 \text { (Ribeiro } \\
2016)\end{array}$ \\
\hline
\end{tabular}




\begin{tabular}{|c|c|c|c|c|c|}
\hline Espécie & Coletor e $\mathbf{n}^{\circ}$ & Local de coleta & $\begin{array}{l}\text { Seção (Filgueiras } \\
\text { 1989) }\end{array}$ & $\begin{array}{l}\text { Subtribo } \\
\text { (Morrone et al. } \\
\text { 2012) }\end{array}$ & $\begin{array}{l}\text { Número } \\
\text { cromossômico }\end{array}$ \\
\hline Mesosetum comatum Swallen & $\begin{array}{l}\text { AROR } 413(\mathrm{UB}) \\
\text { AROR } 418(\mathrm{UB}) \\
\text { AH } 1542(\mathrm{UB})^{*}\end{array}$ & $\begin{array}{l}\text { Brasil, Bahia, } \\
\text { Piatã. } \\
\text { Brasil, Bahia, } \\
\text { Piatã. } \\
\text { Argentina, } \\
\text { Misiones, Dpto. } \\
\text { San Ignacio. }\end{array}$ & Loliiformia & Arthropogoninae & - \\
\hline Mesosetum compressum Swallen & ASS 274 (UB) & $\begin{array}{l}\text { Brasil, } \\
\text { Pernambuco, } \\
\text { Pesqueira. }\end{array}$ & Bifaria & Arthropogoninae & $\begin{array}{l}2 \mathrm{n}=16 \text { (Ribeiro } \\
2016)\end{array}$ \\
\hline Mesosetum elytrochaetum (Hack.) Swallen & RCO 2722 (UB) & $\begin{array}{l}\text { Brasil, Goiás, Alto } \\
\text { Paraíso. }\end{array}$ & Bifaria & Arthropogoninae & $\begin{array}{l}2 \mathrm{n}=24 \text { (Ribeiro } \\
2013)\end{array}$ \\
\hline Mesosetum exaratum (Trin.) Chase & AROR 351 (UB) & $\begin{array}{l}\text { Brasil, Minas } \\
\text { Gerais, Serra do } \\
\text { Cipó. }\end{array}$ & Penicillata & Arthropogoninae & $\begin{array}{l}2 \mathrm{n}=13 \text { (Ribeiro } \\
2016)\end{array}$ \\
\hline Mesosetum ferrugineum (Trin.) Chase & $\begin{array}{l}\text { RCO } 2786(\mathrm{UB}) \\
\text { RCO } 2968(\mathrm{UB}) \\
\text { RCO } 2970(\mathrm{UB})\end{array}$ & $\begin{array}{l}\text { Brasil, Bahia, Rio } \\
\text { de Contas. } \\
\text { Brasil. Distrito } \\
\text { Federal, Parque } \\
\text { Nacional de } \\
\text { Brasília. } \\
\text { Brasil, Goiás, } \\
\text { Cavalcante. } \\
\text { Brasil, Distrito } \\
\text { Federal, Brasília. } \\
\text { Brasil, Distrito } \\
\text { Federal, Brasília. }\end{array}$ & Mesosetum & Arthropogoninae & $\begin{array}{l}2 \mathrm{n}=20 \text { (Ribeiro } \\
2016) \\
2 \mathrm{n}=60 \text { (Sousa } \\
2014)\end{array}$ \\
\hline Mesosetum filifolium F.T. Hubb. & RRI $189(\mathrm{~K})^{*}$ & $\begin{array}{l}\text { Honduras, Cayo, } \\
\text { El Tigre Ranch. }\end{array}$ & Penicillata & Arthropogoninae & - \\
\hline Mesosetum gibbosum Renvoize \& Filg. & AROR 417 (UB) & Brasil, Bahia, & Loliiformia & Arthropogoninae & $2 n=24$ (Ribeiro \\
\hline
\end{tabular}




\begin{tabular}{|c|c|c|c|c|c|}
\hline Espécie & Coletor e $\mathbf{n}^{\circ}$ & Local de coleta & $\begin{array}{l}\text { Seção (Filgueiras } \\
\text { 1989) }\end{array}$ & $\begin{array}{l}\text { Subtribo } \\
\text { (Morrone et al. } \\
\text { 2012) }\end{array}$ & $\begin{array}{l}\text { Número } \\
\text { cromossômico }\end{array}$ \\
\hline & & Piatã. & & & 2016) \\
\hline $\begin{array}{l}\text { Mesosetum loliiforme (Hochst. ex Steud.) } \\
\text { Chase }\end{array}$ & AROR 425 (UB) & $\begin{array}{l}\text { Brasil, Bahia, } \\
\text { Piatã. }\end{array}$ & Loliiformia & Arthropogoninae & \\
\hline & MWSS 63 (UB) & Brasil, Distrito & & & $2 \mathrm{n}=24$ (Sousa \\
\hline & & Federal, Jardim & & & 2014) \\
\hline & & Botânico de & & & \\
\hline & & Brasília. & & & \\
\hline & MWSS 66 (UB) & Brasil, Distrito & & & $2 n=32$ (Sousa \\
\hline & & Federal, Fazenda & & & 2014) \\
\hline & & Água Limpa. & & & \\
\hline & PAR 335 (UB) & Brasil, Minas & & & \\
\hline & & Gerais, Cristália. & & & \\
\hline & RCO 2713 (UB) & Brasil, Goiás, & & & \\
\hline & & Teresina de Goiás. & & & \\
\hline & RCO 2831 (UB) & $\begin{array}{l}\text { Brasil, Tocantins, } \\
\text { Cachoeirinha. }\end{array}$ & & & \\
\hline & V $15816(\mathrm{CEN})$ & Brasil, Goiás, São & & & \\
\hline & & Domingos. & & & \\
\hline & V $15882(\mathrm{CEN})$ & $\begin{array}{l}\text { Brasil, Goiás, } \\
\text { Teresina de Goiás }\end{array}$ & & & \\
\hline & V $15896(\mathrm{CEN})$ & $\begin{array}{l}\text { Brasil, Goiás, } \\
\text { Teresina de Goiás. }\end{array}$ & & & $\begin{array}{l}2 \mathrm{n}=16 \text { (Sousa } \\
2014)\end{array}$ \\
\hline & V 15902 (CEN) & $\begin{array}{l}\text { Brasil, Goiás, } \\
\text { Cavalcante. }\end{array}$ & & & $\begin{array}{l}2 \mathrm{n}=16 \text { (Sousa } \\
2014)\end{array}$ \\
\hline & V $15914(\mathrm{CEN})$ & $\begin{array}{l}\text { Brasil, Goiás, } \\
\text { Teresina de Goiás. }\end{array}$ & & & $\begin{array}{l}2 \mathrm{n}=16 \text { (Sousa } \\
2014)\end{array}$ \\
\hline Mesosetum longiaristatum Filg. & & $\begin{array}{l}\text { Brasil, Goiás, } \\
\text { Teresina de Goiás. }\end{array}$ & Bifaria & Arthropogoninae & $\begin{array}{l}2 \mathrm{n}=8 \text { (Ribeiro } \\
\text { et al. } 2015 \text { ) }\end{array}$ \\
\hline & V 15812 (CEN) & Brasil, Goiás, São & & & $2 n=24$ (Ribeiro \\
\hline & & Domingos. & & & 2013) \\
\hline
\end{tabular}




\begin{tabular}{|c|c|c|c|c|c|}
\hline Espécie & Coletor e $\mathbf{n}^{\circ}$ & Local de coleta & $\begin{array}{l}\text { Seção (Filgueiras } \\
\text { 1989) }\end{array}$ & $\begin{array}{l}\text { Subtribo } \\
\text { (Morrone et al. } \\
\text { 2012) }\end{array}$ & $\begin{array}{l}\text { Número } \\
\text { cromossômico }\end{array}$ \\
\hline & V 15841 (CEN) & $\begin{array}{l}\text { Brasil, Goiás, São } \\
\text { Domingos. }\end{array}$ & & & $\begin{array}{l}2 \mathrm{n}=24 \text { (Ribeiro } \\
2013)\end{array}$ \\
\hline Mesosetum pappophorum (Nees) Kuhlm. & $\begin{array}{l}\text { V } 15949(\mathrm{CEN}) \\
\text { V } 15953(\mathrm{CEN})\end{array}$ & $\begin{array}{l}\text { Brasil, Goiás, } \\
\text { Flores de Goiás. } \\
\text { Brasil, Goiás, } \\
\text { Flores de Goiás. }\end{array}$ & Loliiformia & Arthropogoninae & $\begin{array}{l}2 \mathrm{n}=8 \text { (Ribeiro } \\
2016)\end{array}$ \\
\hline Mesosetum penicillatum $\mathrm{Mez}$ & DPS. 329 (UB) & $\begin{array}{l}\text { Brasil, Tocantins, } \\
\text { Estação Ecológica } \\
\text { Serra Geral do } \\
\text { Tocantins. }\end{array}$ & Penicillata & Arthropogoninae & - \\
\hline Mesosetum pittieri Hitchc. & RWP $12648(\mathrm{~K})^{*}$ & $\begin{array}{l}\text { Costa Rica, } \\
\text { Guanacaste, } \\
\text { Murciélago. }\end{array}$ & Sclerochloae & Arthropogoninae & $\begin{array}{l}2 \mathrm{n}=16^{* *}(\text { Pohl } \\
\& \text { Davidse } 1971)\end{array}$ \\
\hline Mesosetum rottboellioides (Kunth) Hitchc. & $\begin{array}{l}\text { AROR } 420(\mathrm{UB}) \\
\text { PAR } 331(\mathrm{UB}) \\
\text { PAR } 339(\mathrm{UB})\end{array}$ & $\begin{array}{l}\text { Brasil, Bahia. } \\
\text { Brasil, Minas } \\
\text { Gerais, Grão } \\
\text { Mogol. } \\
\text { Brasil, Minas } \\
\text { Gerais, Cristália. }\end{array}$ & Mesosetum & Arthropogoninae & $\begin{array}{l}2 \mathrm{n}=20 \text { (Sousa } \\
2014)\end{array}$ \\
\hline Mesosetum sclerochloa (Trin.) Hitchc. & $\begin{array}{l}\text { RCO } 2739 \text { (UB) } \\
\text { V } 15937(\mathrm{CEN}) \\
\text { V } 15950(\mathrm{CEN}) \\
\text { V } 15954(\mathrm{CEN})\end{array}$ & $\begin{array}{l}\text { Brasil, Goiás, } \\
\text { Flores de Goiás. } \\
\text { Brasil, Goiás, } \\
\text { Flores de Goiás. } \\
\text { Brasil, Goiás, } \\
\text { Flores de Goiás. } \\
\text { Brasil, Goiás, } \\
\text { Flores de Goiás. }\end{array}$ & Sclerochloae & Arthropogoninae & $\begin{array}{l}2 \mathrm{n}=16 \text { (Ribeiro } \\
2016)\end{array}$ \\
\hline Mesosetum sp. nov. 1 & JJG $16271(\mathrm{CAY})^{*}$ & $\begin{array}{l}\text { Guiana Francesa, } \\
\text { Marouini }\end{array}$ & Mesosetum & Arthropogoninae & - \\
\hline Mesosetum wrightii Hitchc. & ELE $11552(\mathrm{~K})^{*}$ & Cuba, Pinar del & Penicillata & Arthropogoninae & - \\
\hline
\end{tabular}




\begin{tabular}{|c|c|c|c|c|c|c|}
\hline Espécie & Coletor e $\mathbf{n}^{\circ}$ & Local de coleta & $\begin{array}{l}\text { Seção } \\
\text { 1989) }\end{array}$ & (Filgueiras & $\begin{array}{l}\text { Subtribo } \\
\text { (Morrone et al. } \\
\text { 2012) }\end{array}$ & $\begin{array}{l}\text { Número } \\
\text { cromossômico }\end{array}$ \\
\hline & & Rio. & & & & \\
\hline \multicolumn{7}{|l|}{ Grupo externo } \\
\hline \multirow[t]{2}{*}{ Anthaenantia lanata (Kunth) Benth. } & ASS $281(\mathrm{UB})$ & $\begin{array}{l}\text { Brasil, Tocantins, } \\
\text { Natividade. }\end{array}$ & & - & Otachyriinae & $\begin{array}{l}2 \mathrm{n}=40^{* *} \\
\text { (Hidalgo et al. } \\
\text { 2007) }\end{array}$ \\
\hline & AROR 403 (UB) & $\begin{array}{l}\text { Brasil, Tocantins, } \\
\text { Natividade. }\end{array}$ & & & & \\
\hline Arthropogon villosus Nees & $\begin{array}{l}\text { RCO } 2969 \text { (UB) } \\
\text { RCO } 2971(\text { UB) }\end{array}$ & $\begin{array}{l}\text { Brasil, Distrito } \\
\text { Federal, Brasília. } \\
\text { Brasil, Distrito } \\
\text { Federal, Brasília. }\end{array}$ & & - & Arthropogoninae & $\begin{array}{l}2 \mathrm{n}=40 \text { (Ribeiro } \\
2017) \\
2 \mathrm{n}=40 \text { (Ribeiro } \\
2017)\end{array}$ \\
\hline Echinolaena inflexa (Poir.) Chase & PAR 338 (UB) & $\begin{array}{l}\text { Brasil, Mias } \\
\text { Gerais, Critália. }\end{array}$ & & - & Paspalinae & $\begin{array}{l}2 \mathrm{n}=60 * * \text { (Gould } \\
\& \quad \text { Sordestrom } \\
1967)\end{array}$ \\
\hline Homolepis aturensis (Kunth) Chase & RCO 3011 (UB)* & $\begin{array}{l}\text { Brasil, Amazonas, } \\
\text { Presidente } \\
\text { Figueiredo. }\end{array}$ & & - & Arthropogoninae & $\begin{array}{l}2 \mathrm{n}=20 * *(\mathrm{Pohl} \\
\& \text { Davidse } 1971)\end{array}$ \\
\hline $\begin{array}{l}\text { Homolepis glutinosa (Sw.) Zuloaga \& } \\
\text { Soderstrom }\end{array}$ & $\begin{array}{l}\text { PAR } 317(\mathrm{UB}) \\
\text { V } 15991(\mathrm{CEN})\end{array}$ & $\begin{array}{l}\text { Brasil, Distrito } \\
\text { Federal, Brasília. } \\
\text { Brasil, Paraná, } \\
\text { Castro. }\end{array}$ & & - & Arthropogoninae & $\begin{array}{l}2 \mathrm{n}=40 * *(\mathrm{Pohl} \\
\& \text { Davidse } 1971)\end{array}$ \\
\hline Homolepis isocalycia (G. Mey.) Chase & PAR 332 (UB) & $\begin{array}{l}\text { Brasil, Minas } \\
\text { Gerais, Grão } \\
\text { Mogol. }\end{array}$ & & - & Arthropogoninae & $\begin{array}{l}2 \mathrm{n}=40 * * \text { (Gould } \\
\& \quad \text { Sordestrom } \\
1967)\end{array}$ \\
\hline Homolepis longispicula (Döll) Chase & RCO 2561 (UB) & $\begin{array}{l}\text { Brasil, Goiás, Alto } \\
\text { Paraíso. }\end{array}$ & & - & Arthropogoninae & - \\
\hline $\begin{array}{l}\text { Keratochlaena rigidifolia (Filg. et al.) } \\
\text { Morrone \& Zuloaga }\end{array}$ & V $8432(\mathrm{CEN})^{*}$ & $\begin{array}{l}\text { Brasil, Maranhão, } \\
\text { Loreto. }\end{array}$ & & - & Arthropogoninae & - \\
\hline Oncorachis macrantha (Trin.) Morrone \& & RCO 2788 (UB) & Brasil, Goiás, & & - & Arthropogoninae & - \\
\hline
\end{tabular}




\begin{tabular}{|c|c|c|c|c|c|c|}
\hline Espécie & Coletor e $\mathbf{n}^{\circ}$ & Local de coleta & $\begin{array}{l}\text { Seção } \\
\text { 1989) }\end{array}$ & (Filgueiras & $\begin{array}{l}\text { Subtribo } \\
\text { (Morrone et al. } \\
\text { 2012) }\end{array}$ & $\begin{array}{l}\text { Número } \\
\text { cromossômico }\end{array}$ \\
\hline Zuloaga & & Cavalcante. & & & & \\
\hline $\begin{array}{l}\text { Oplismenopsis najada (Hack. \& Arechav.) } \\
\text { Parodi }\end{array}$ & V 16017 (CEN) & $\begin{array}{l}\text { Brasil, Rio Grande } \\
\text { do Sul, São } \\
\text { Lourenço do Sul. }\end{array}$ & & - & Arthropogoninae & - \\
\hline Streptostachys asperifolia Desv. & AROR 423 (UB) & $\begin{array}{l}\text { Brasil, Bahia, } \\
\text { Piatã. }\end{array}$ & & - & Paspalinae & $\begin{array}{l}2 \mathrm{n}=20^{* *} \\
\text { (Morrone et al. } \\
\text { 1995) }\end{array}$ \\
\hline $\begin{array}{l}\text { Tatianyx arnacites (Trin.) Zuloaga \& } \\
\text { Soderstr. }\end{array}$ & AROR 411 (UB) & $\begin{array}{l}\text { Brasil, Bahia, Rio } \\
\text { de Contas. }\end{array}$ & & - & Arthropogoninae & $\begin{array}{l}2 \mathrm{n}=60 \text { (Ribeiro } \\
2016)\end{array}$ \\
\hline
\end{tabular}


- Extração de DNA, PCR e Sequênciamento

A extração do DNA genômico foi realizada a partir de folhas acondicionadas em sílica gel ou de material fresco, quando disponível, de acordo com o protocolo CTAB (Doyle \& Doyle 1987) com modificações. Primeiramente as folhas foram trituradas com $\mathrm{N}_{2}$ líquido e incubadas por 45 min a $65^{\circ} \mathrm{C}$ em uma solução com $700 \mu \mathrm{L}$ de CTAB $2 \%$ e $1 \%$ de $\beta$-mercaptoetanol e posteriormente com clorofórmio : álcool isoamílico (24:1). O DNA foi precipitado em álcool isopropílico, lavado com etanol e ressuspendido em $100 \mu \mathrm{L}$ de tampão Tris-EDTA. Para as amostras de herbário, o DNA foi extraído utilizando o DNeasy Plant Mini Kit (QIAGEN GmbH, Hilden, Germany).

Os produtos da extração foram testados e quantificados por meio de eletroforese horizontal em gel de agarose $1 \%$, corado com brometo de etídio e visualizados em transiluminador de luz ultravioleta (UV). A qualidade do DNA extraído foi avaliada e sua concentração estimada por meio de um marcador de peso molecular.

Para este trabalho, foram utilizadas quatro regiões de DNA plastidial: o gene matK, o intron $\operatorname{trn} \mathrm{L}$, os espaçadores intergênicos $\operatorname{trn} \mathrm{L}-\operatorname{trn} \mathrm{F}$ e $p s b \mathrm{~A}-t r n \mathrm{H}$; e uma região nuclear (ITS), listados na Tabela 2.

A amplificação de regiões do DNA foi realizada usando a Reação em Cadeia de Polimerase - PCR. Para as reações de PCR, utilizaram-se aproximadamente 15 ng do DNA genômico; 2,5 mg/ml de cada dNTPs; $2,5 \mathrm{mg} / \mathrm{ml}$ de BSA; 0,25 mM de cada primer; $1 \mathrm{U}$ de Taq polimerase; $1 x$ de tampão para Taq DNA Polimerase e água ultrapura estéril, com volume final de $15 \mu \mathrm{L}$. As reações foram realizadas em um termociclador Veriti ${ }^{\circledR}$ 96-Well (Applied Biosystems) sob as seguintes condições: $95^{\circ} \mathrm{C}$ por 2 minutos, 35 ciclos de $95^{\circ} \mathrm{C}$ por $30 \mathrm{seg}$., $52-54^{\circ} \mathrm{C}$ por $1 \mathrm{~min}$. e $72^{\circ} \mathrm{C}$ por 1 min, seguidos de uma extensão final a $72^{\circ} \mathrm{C}$ por 7 minutos. Os produtos da reação foram visualizados por eletroforese horizontal em geis de agarose 1,5\% em tampão SB 1X, corados com brometo de etídio e fotografados sob luz UV. Apenas para ITS, foram acrescentados às reações de PCR trehalose $1 \mathrm{M}$ e etileno glicol $0,67 \mathrm{M}$, e a temperatura de anelamento foi de $60^{\circ} \mathrm{C}$. 
Os produtos da PCR foram purificados utilizando as enzimas exonuclease I (EXO) e fosfatase alcalina de camarão (SAP) e depois sequênciados em ambas as direções usando o Big Dye Terminator v3.1 Cycle Sequencing Kit (Applied Biosystems, Austin, Texas, USA) seguindo o seguinte protocolo: 1 min inicial de desnaturação a $96^{\circ} \mathrm{C}, 35$ ciclos de $96^{\circ} \mathrm{C}$ por $10 \mathrm{seg}$., $50^{\circ} \mathrm{C}$ por 15 seg., e $60^{\circ} \mathrm{C}$ por 4 min. Os produtos foram purificados utilizando etanol $100 \%$ e $70 \%$, e sequênciados em um ABI automated DNA analyzer 3730 (Applied Biosystems, Foster City, CA, USA).

Tabela 2. Sequência e referência dos primers utilizados nas amplificações por PCR.

\begin{tabular}{|c|c|c|c|}
\hline & Nome do primer & Sequência (5'-3') & bReferência \\
\hline \multirow{2}{*}{ matK } & 3F_Kim F & CGTACAGTACTTTTGTGTTTACGAG & Sugita et al .(1985) \\
\hline & 1R_kim R & ACCCAGTCCATCTGGAAATCTTGGTTC & Avraham et al. (1995) \\
\hline \multirow{2}{*}{$p s b \mathrm{~A}-t r n \mathbf{H}$} & $\mathrm{psbA}$ & CGAAGCTCCATCTACAAATGG & Sang et al. (1997) \\
\hline & $\operatorname{trnH}$ & ACTGCCTTGATCCACTTGGC & \\
\hline \multirow{2}{*}{$\operatorname{trn} L, \operatorname{trn} L-F$} & $\operatorname{trnLF}$ & CGAAATCGGTAGACGCTACG & Taberlet et al. (1991) \\
\hline & $\operatorname{trnL~R}$ & GGGGATAGAGGGACTTGAAC & \\
\hline \multirow{2}{*}{ ITS } & ITS1 & TTCCGTAGGTGAACCTGCGG & White et al. (1990) \\
\hline & ITS4 & TCCTCCGCTTATTGATATGC & \\
\hline
\end{tabular}

- Análises filogenéticas

Todas as sequências utilizadas nas reconstruções filogenéticas são inéditas. As sequências obtidas foram alinhadas no software MAFFT 7 online (Katoh \& Standley 2013), com subsequente inspeção visual e eventuais ajustes manuais. Os indels foram considerados como dados perdidos ou codificados, se informativos. Os indels foram tratados com um algoritmo de codificação simples no software FastGap 1.2.1 (Borchsenius 2009). A matriz de sequências alinhadas foi analisada por Máxima Parcimônia (MP), Máxima Verossimilhança (MV) e Inferência Bayesiana (IB) para toda a base de dados isoladas, nuclear e plastidial e combinadas. Para a matriz combinada, foram aplicadas 
duas partições, uma para a região nuclear e uma para as quatro regiões plastidiais combinadas. A avaliação do grau de congruência entre as topologias obtidas foi feita usando-se o teste ILD (“Incongruence-length difference test”) (Farris et al. 1995). Todas as análises foram realizadas através do portal online CIPRES (Miller et al. 2010).

As análises de Máxima Parcimônia foram conduzidas no programa PAUP*v4.0b10 (Swofford 2003). As análises constituíram de 1000 replicações utilizando a busca heurística de sequências e o rearranjo de ramos das árvores foi utilizado pelo algoritmo TBR (Tree Bisection and Reconnection). O grau de sustentação dos ramos foi estimado pela análise de bootstrap (Felsenstein 1985) a partir de 10.000 replicações. Os níveis de homoplasia e sinapomorfia foram calculados usando os índices de consistência (IC), de retenção (IR) e de consistência reescalonado (RC). Os caracteres foram tratados com o mesmo peso e os multiestados não ordenados.

A análise de Máxima Verossimilhança foi feita com RAxML-HPC v.8 on XSEDE (Stamatakis 2006), usando o algoritmo de bootstrap (Felsenstein 1985) com 1000 replicações. Todos os outros parâmetros foram marcados como padrão.

Análises de Inferência Bayesiana foram realizadas utilizando o programa MrBayes 3.2.6 (Ronquist \& Huelsenbeck 2003). O jModelTest2 on XSEDE (2.1.6) foi utilizado para apontar o modelo evolutivo mais adequado para cada conjunto de dados. Os modelos encontrados baseados no Akaike Information Criterion foram: SYM+I+G para ITS, GTR+G para a partição plastidial e Mixed para plastídeos+ITS. Duas análises bayesianas independentes foram feitas, cada uma com quatro cadeias de Monte Carlo Markov com 100.000.000 de gerações, com árvores amostradas a cada 1.000 gerações, sendo que $25 \%$ das amostras iniciais (burn in) coletadas foram descartadas e as remanescentes foram utilizadas para determinar os valores de Probabilidade Posterior (PP).

Todas as árvores foram visualizadas e editadas no programa FigTree version 1.4.3 (http://tree.bio.ed.ac.uk/software/figtree/). 


\section{Resultados}

Foram geradas 288 sequências a partir dos marcadores utilizados, todas inéditas. A base de dados produzida com a matriz de ITS e a matriz com os marcadores plastidiais combinada gerou um total de $2767 \mathrm{pb}$, sendo $745 \mathrm{pb}$ do ITS e $2.028 \mathrm{pb}$ de regiões plastidiais. A partição de ITS apresentou maior variabilidade $(35,7 \%)$ em relação a partição plastidial $(11,86 \%)$. O índice de consistência (IC) e o índice de retenção da partição plastidial foram de 0,82 e 0,85 , respectivamente. Para ITS, o índice de consistência (IC) e o índice de retenção foram de 0,57 e 0,86 , respectivamente.

Os testes de incongruência (ILD) realizados para as partições plastidiais e nucleares foram significativos $(\mathrm{p}<0,01)$, o que indica que as partições moleculares são incongruentes entre si. Apesar da significância do teste, as partições plastidiais e nucleares foram combinadas, pois não foi observado conflito evidente entre as topologias.

A análise dos dados plastidiais se mostrou pouco informativa para o grupo de estudo (Figura 1). Dentre os poucos clados formados, o Clado A, composto pelas espécies de Mesosetum sect. Mesosetum é a única seção do gênero que mostrou-se monofilética neste estudo, agrupando todas as espécies pertencentes a esta seção, delimitada por Filgueiras (1989). Nesta análise, também foi possível observar a parafilia de M. bifarium e M. longiaristatum.

A análise de ITS em separado apresentou, de maneira geral, clados com altos valores de probabilidades posteriores: Clado A ( $\mathrm{PP}=1,00)$, Clado B $(\mathrm{PP}=1,00)$, Clado C $(\mathrm{PP}=1,00)$ e Clado D $(\mathrm{PP}=1,00)$. Mesosetum exaratum como grupo irmão do Clado A, formado pelas espécies de $M$. sect. Mesosetum. Tatianyx arnacites como grupo irmão do Clado B, composto por M. ansatum e algumas espécies referidas à $M$. sect. Loliiformia por Filgueiras (1989). Nesta análise, M. bifarium também mostrou-se parafilética.

A análise de Inferência Bayesiana combinada (ITS + plastídios) gerou clados mais fortemente suportados. Nesta análise, é possível verificar dois grandes clados formados por espécies 
de Mesosetum (Clado A e Clado B), enquanto que T. arnacites forma uma politomia, não se agrupando com nenhum desses clados (Figura 3).

O Clado A inclui todas as espécies de $M$. sect. Mesosetum (M. cayennense, $M$. rottboellioides e $M$. ferrugineum), suportado por $100 \%$ de probabilidades posteriores, corroborando a forte relação entre essas espécies, assim como mostrado nas análises dos dados de ITS e plastidiais isoladamente. O Clado B, também altamente suportado (100\% de bootstrap), agrupa as demais espécies de Mesosetum. Com exceção de $M$. sect. Mesosetum, nenhuma outra seção proposta por Filgueiras (1989) mostrou-se monofilética.

As análises de Máxima Parcimônia (Anexo 1) e Máxima Verossimilhança (Anexo 2) se mostraram altamente congruente com a análise de Inferência Bayesiana, assim, a discussão será focada na topologia apresentada pela IB feita para a matriz de dados contendo as duas partições (nuclear e plastidial) combinadas.

Todas as 36 espécies e 72 acessos foram sequênciados com sucesso para os marcadores plastidiais, com exceção de Keratochlaena rigidifolia ( $V$ 8432). Esta espécie é conhecida apenas da sua localidade típica e as tentativas de recoleta ao longo da realização do presente trabalho foram infrutíferas. Portanto, o DNA de Keratochlaena foi extraído de uma única amostra de herbário disponível utilizando três diferentes protocolos (Doyle \& Doyle 1987, Storchová et al. 2000 e DNeasy Plant Mini Kit), obtendo-se êxito em amplificar e sequenciar a região psbA-trnH. Por isso, esta espécie não entrou na análise. 


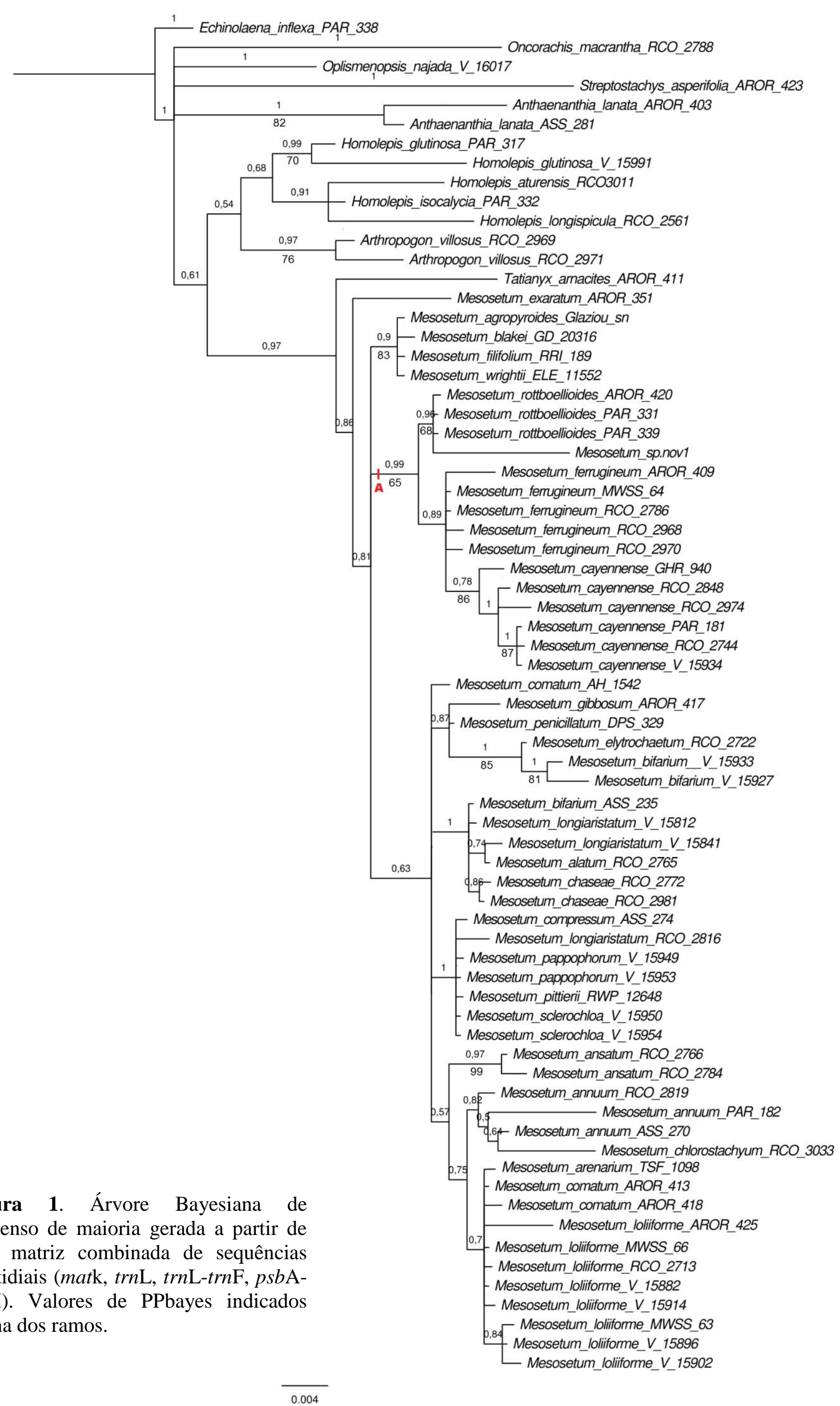




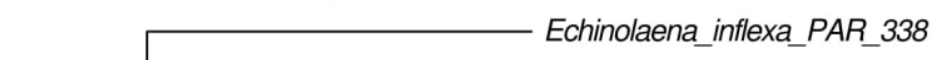

1 Arthropogon_villosus_RCO_2971

Arthropogon_villosus_RCO_2969

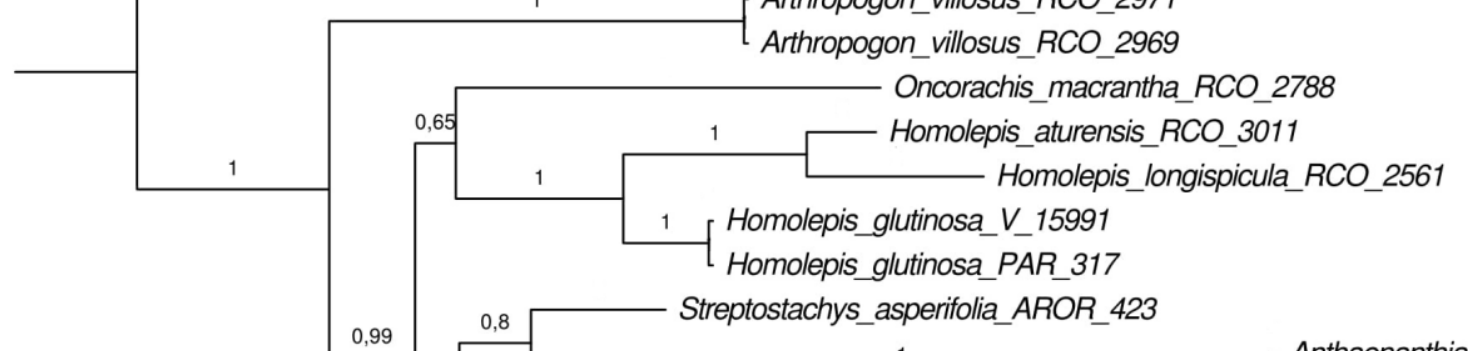

[ Anthaenanthia_lanata_AROR_403

Anthaenanthia_lanata_ASS_281

Oplismenopsis_najada_V_16017

-Mesosetum_exaratum_AROR 351

1 Mesosetum_rottboellioides_PAR_339

\begin{tabular}{r|r|r|r|r|r|}
0,98 & $100\left[\begin{array}{l}\text { Mesosetum_rottboellioides_AROR_420 } \\
84\end{array}\right.$ \\
\hline
\end{tabular}

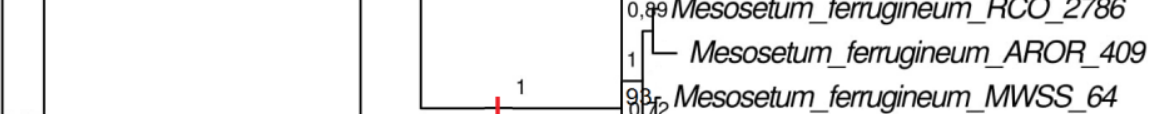

0,5

$A^{100}$

Mesosetum ferrugineum $R C 02970$

\Mesosetum_ferrugineum_RCO 2970

Mesosetum_cayennense_RCO_2848
- Mesosetum_cayennense PAR_181

$\begin{array}{rrr}1 & & \text { Mesosetum_cayennense_GHR_940 } \\ 100 & & \text { Mesosetum_cayennense_RCO_2974 } \\ & 0 \text { Mesosetum_cayennense_RCO_2744 }\end{array}$

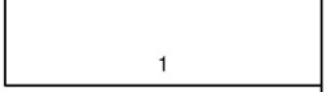

100

Figura 2. Árvore Bayesiana de consenso de maioria gerada a partir de uma matriz de sequências nucleares (ITS). Valores de PPbayes indicados acima dos ramos.

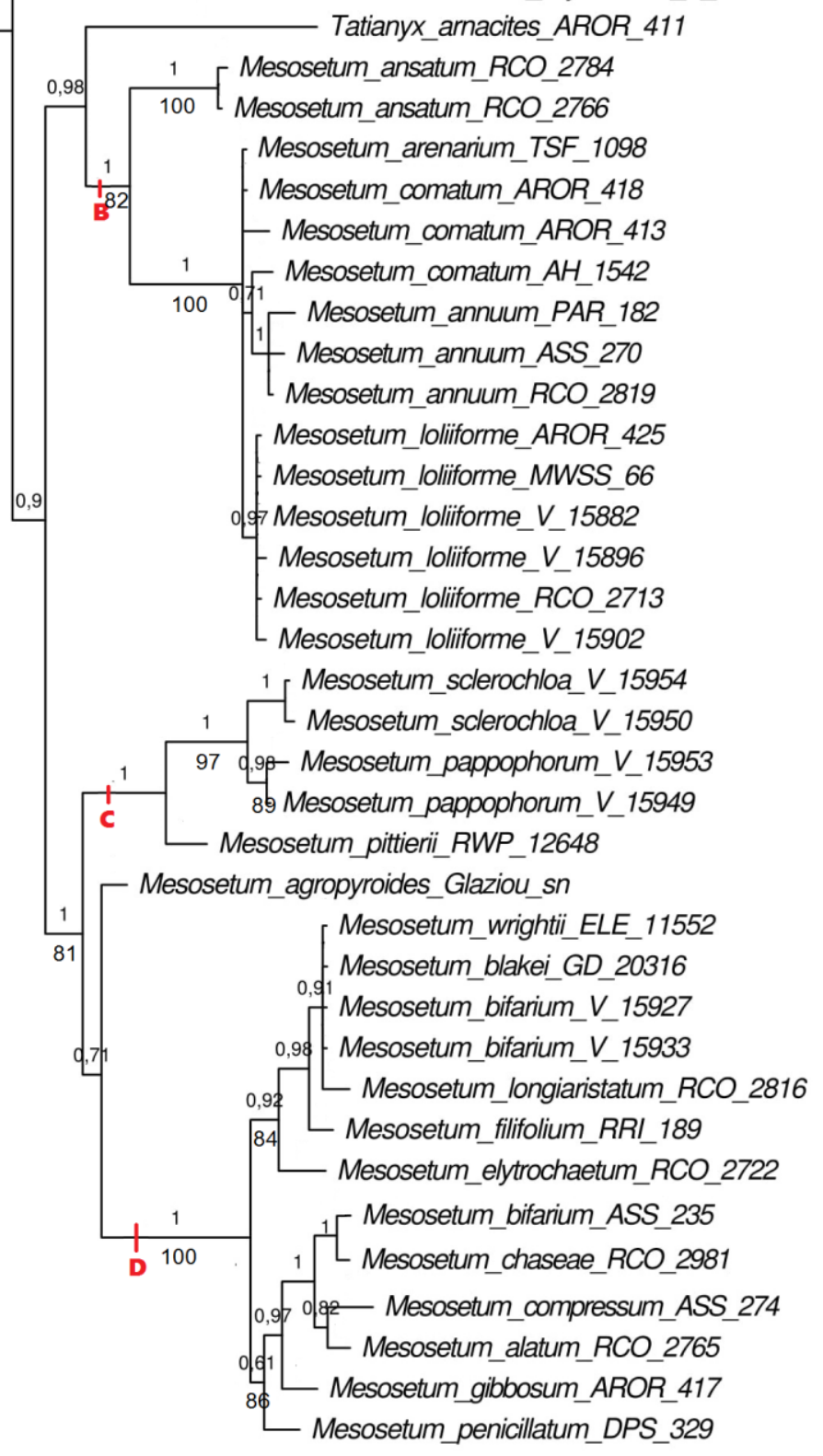


Echinolaena_inflexa_PAR_338 $(2 \mathrm{n}=60)^{*}$

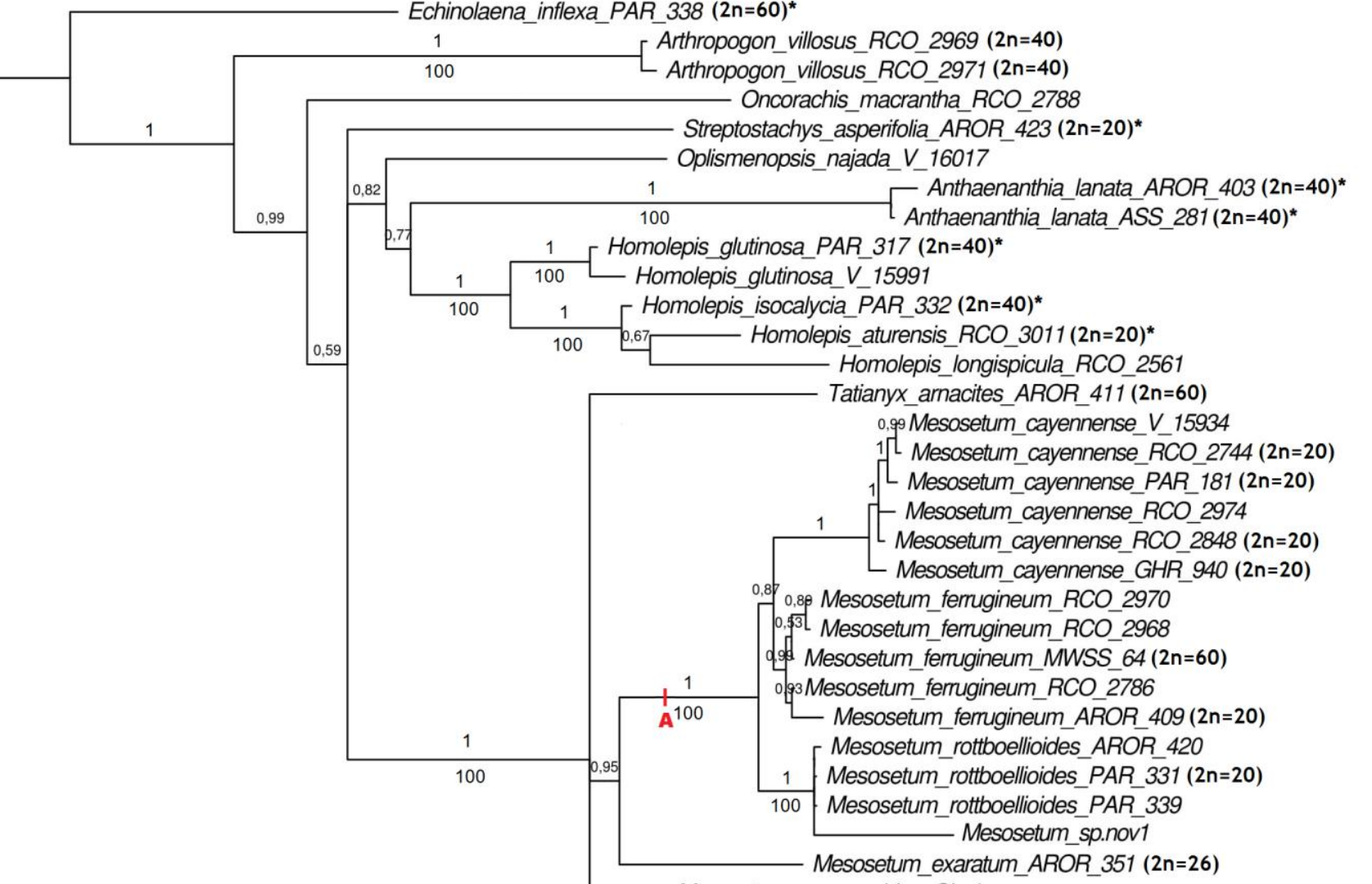

Clado $\mathrm{x}=10$

Figura 3. Árvore Bayesiana de consenso de maioria gerada a partir de uma matriz combinada de sequências plastidiais (matk, trnL, trn $\mathrm{L}-t r n \mathrm{~F}, p s b \mathrm{~A}-t r n \mathrm{H}) \mathrm{e}$ nuclear (ITS) combinadas. Valores de PPbayes indicados acima dos ramos. Valores de bootstrap indicados abaixo dos ramos. Números cromossômicos de acordo com a Tabela 1.

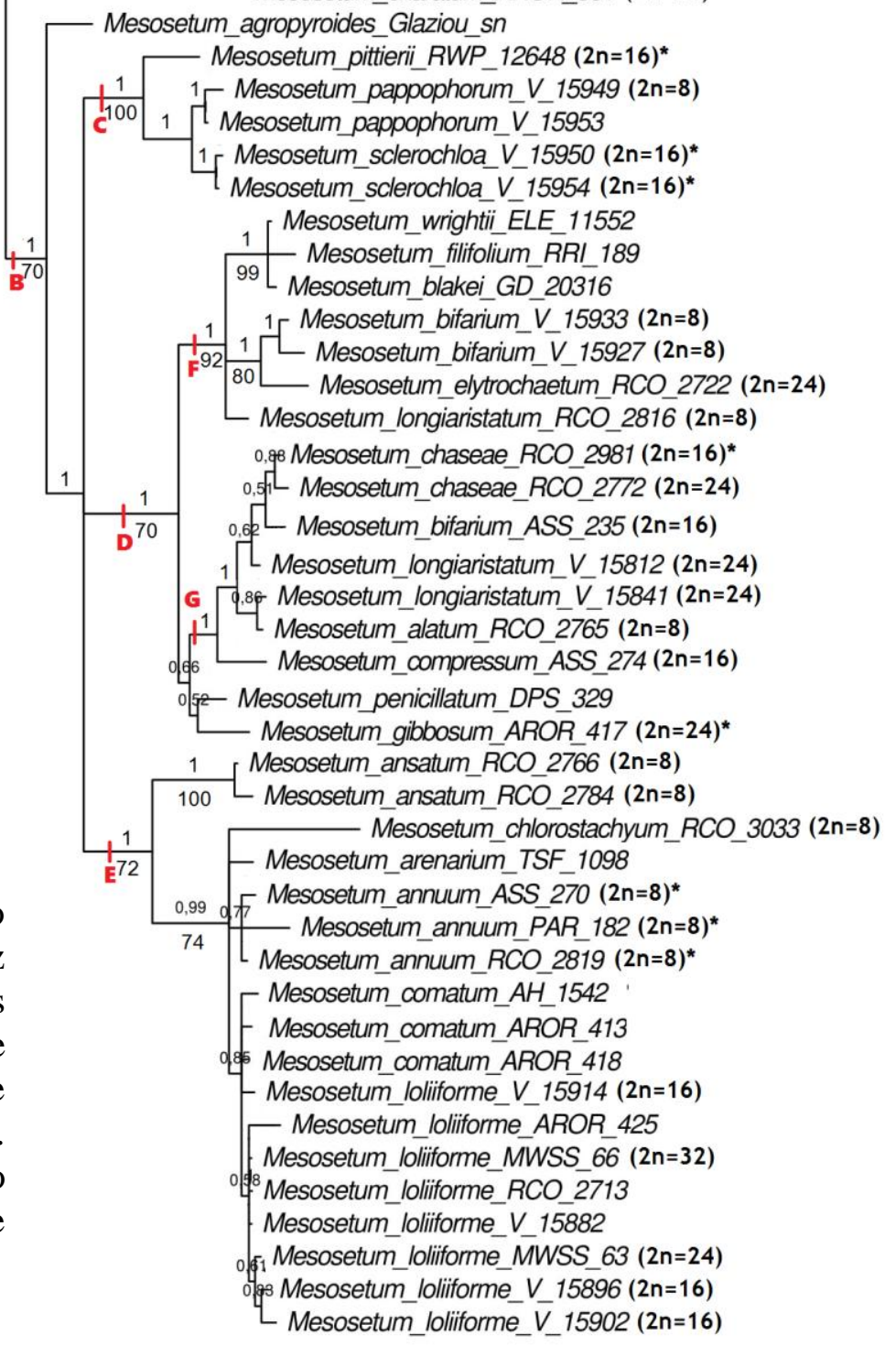




\section{Discussão}

A topologia final obtida a partir dos dados combinados (Figura 3) mostrou uma resolução significativamente superior às análises anteriores. Os resultados baseados em Máxima Parcimônia (Anexo 1) e Inferência Bayesiana (Figuras 1, 2 e 3) suportam o monofiletismo de Mesosetum se o gênero monoespecífico Tatianyx for incluído dentro do grupo, com 100\% de bootstrap e 1.0 PP (Figuras 1, 2 e 3). Com a inclusão de T. arnacites, o gênero Mesosetum, a partir da topologia obtida, apresenta três principais linhagens evolutivas bem suportadas. No entanto, a relação entre elas não é resolvida em definitivo.

Não foram observadas grandes incongruências nas análises plastidiais e nucleares. As únicas incongruências detectadas são relacionadas com a posição de alguns taxa ao nível de espécie entre os dados plastidiais combinados e ITS, no entanto, eles não afetam quaisquer conclusões deste estudo. Os dados plastidiais apresentaram baixa variabilidade e pouca resolução nas análises individuais e contribuíram pouco para o entendimento das relações filogenéticas em Mesosetum. Os poucos clados bem suportados nas análises plastidiais, também aparecem nas análises de ITS, indicando baixo conflito.

Apesar da incongruência entre as partições nucleares e plastidiais, as análises combinadas foram muito úteis, visto que esta incongruência foi localizada, semelhante a vários outros estudos filogenéticos moleculares (Ramirez 2006, Scataglini et al. 2014, Oliveira et al. 2014, Silva et al. 2015a). A incongruência em nossos dados pode ter surgido por causa da herança distinta das regiões (ITS biparental e plastídios uniparental) associada à ocorrência de muitas espécies poliploides em Mesosetum, ou de outros problemas encontrados no uso de ITS para inferência filogenética, como a presença de paralogia e dificuldades no alinhamento (Álvarez \& Wendel 2003, van den Berg et al. 2005).

Tatianyx arnacites forma uma linhagem evolutiva única dentro de Mesosetum (Figuras 1, 2 e 3). Giussani et al. (2001), Duvall et al. (2001) e Morrone et al. (2012) já haviam apontado a forte 
relação filogenética de Tatianyx com Mesosetum. Morfologicamente, T. arnacites compartilha várias características com Mesosetum, tais como a pilosidade das glumas e lema inferior, inserção da espigueta no pedicelo e cariopse com hilo linear. A presença de ramos floríferos paniculiformes em Tatianyx era o único caracter anteriormente utilizado para sua distinção de Mesosetum. Com a inclusão de Tatianyx, altamente suportada em caracteres moleculares, amplia-se no presente trabalho a cincurscrição morfológica do gênero Mesosetum.

O clado A engloba todas as espécies originalmente aceitas em $M$. sect. Mesosetum (Filgueiras 1989), tendo M. exaratum (previamente M. sect. Penicillata) como grupo irmão dessas espécies. Mesosetum cayennense, M. rottboellioides e M. ferrugineum constituem um clado homogêneo, e são únicas no gênero por apresentarem tricomas castanhos a ferrugíneos na espigueta e antécio superior com uma papila composta por célula epidérmica (Silva et al. 2015b, Capítulo 4). As demais espécies de Mesosetum, incluindo Tatianyx, possuem tricomas alvos e papilas simples ou quando compostas, há coalescência entre as papilas (Silva et al. 2015b, Capítulo 4). A monofilia de M. sect. Mesosetum foi comprovada em todas as análises (Figuras 1, 2 e 3). A nova espécie descrita no Capítulo 3 é relacionada a este clado e compartilha das mesmas características citadas acima.

$\mathrm{O}$ número cromossômico básico $\mathrm{x}=10$ é encontrado em Mesosetum cayennense, $M$. rottboellioides e M. ferrugineum (Sousa 2014, Ribeiro 2016). Foram encontrados apenas citótipos diploides em $M$. cayennense e $M$. rottboellioides, ambas com 2n = 20 cromossomos (Sousa 2014, Ribeiro 2016). Em M. ferrugineum, foram encontrados citótipos diploide com 2n = 20 (AROR 409UB) e hexaploide com 2n = 60 cromossomos (3X) (MWSS 64-UB) (Sousa 2014, Ribeiro 2016). O citótipo diploide $(2 \mathrm{n}=20)$ corresponde a $M$. ferrugineum var. setaceum, descrita por Filgueiras (1986) e não aceita em Filgueiras (1989). Mesosetum ferrugineum var. setaceum distingue-se da variedade típica por apresentar lâminas filiformes (na variedade típica, as lâminas são planas) e distribuição restrita aos campos rupestres da Serra do Cipó e Lavras Novas, Minas Gerais (Filgueiras 1986). Recentemente, foi encontrada em Rio de Contas, na Bahia (Tabela 1). 
Mesosetum exaratum é a única espécie da subfamília Panicoideae que apresenta número cromossômico básico $\mathrm{x}=13$, o que dificulta discutir sobre sua origem e evolução. Segundo Ribeiro (2016), o número cromossômico básico $\mathrm{x}=13$ provavelmente derivou-se de $\mathrm{x}=10$ por fissão ou duplicação de cromossomos, visto que foi observada a presença de dois pares cromossômicos com instabilidade no centrômero em M. exaratum, o que pode representar indícios de uma tendência no aumento do número cromossômico por fissão centromérica no clado.

O clado B compreende as demais espécies de Mesosetum e sugere que M. agropyroides divergiu mais cedo da principal linha de evolução deste clado. Todos os membros do clado B que apresentam registros de contagem cromossômica disponível, compartilham o mesmo número cromossômico básico $\mathrm{x}=4$ (Ribeiro 2016). Neste clado, há espécies que apresentam vários níveis de ploidia. Além disso, os táxons do clado B possuem espiguetas glabras ou com tricomas alvos. Nenhuma espécie deste clado possui tricomas ferrugíneos na espigueta. Dentro do clado B, podemos observar três subclados altamente suportados: os subclados C, D, e E (Figura 3).

O subclado C é formado pelas espécies M. sclerochloa, M. pappophorum e M. pittieri como grupo irmão. Mesosetum sclerochloa e M. pittieri foram relacionadas a $M$. sect. Sclerochloae e $M$. pappophorum a M. sect. Loliiformia (Filgueiras 1989). Os membros deste clado compartilham características morfológicas, tais como o hábito decumbente e nervuras anastomosadas proeminentes nas glumas e lema inferior.

O subclado D é o mais heterogêneo em relação ao número de espécies. Internamente, algumas espécies parecem não estar muito bem resolvidas, tais como o pequeno clado formado por M. penicillatum e $M$. gibbosum, que apresenta um suporte insuficiente $(\mathrm{PP}=52)$. Por outro lado, pode-se verificar a ocorrência de dois subclados altamente suportados: Subclados F e G. No subclado F, as espécies $M$. wrightii, M. filifolium e $M$. blakei foram relacionadas à $M$. sect. Penicillata por Filgueiras (1989) e eram conhecidas apenas da América Central. Mesosetum filifolium foi recentemente encontrada no Brasil, em Carajás, no Município de Paraupebas, no Sul 
do Estado do Pará (Silva et al. 2016, Capítulo 5). Para esta filogenia, foi utilizada a amostra proveniente de Honduras. Não há registros de contagens cromossômicas para estas espécies.

O citótipo diploide de $M$. bifarium $(2 \mathrm{n}=8)$ no subclado $\mathrm{F}$ mostrou estreita relação com $M$. elytrochaetum $(2 \mathrm{n}=24)$, enquanto que o citótipo poliploide $(2 \mathrm{n}=16)$ desta espécie é mais relacionada ao subclado $\mathrm{G}$, constituído por $M$. chaseae $(2 \mathrm{n}=24$, poliploide), M. longiaristatum $(2 \mathrm{n}$ $=24$, poliploide $), M$. alatum $(2 \mathrm{n}=8)$ e $M$. compressum $(2 \mathrm{n}=16)$. Além da parafilia de $M$. bifarium, também podemos observar a parafilia de $M$. longiaristatum. O citótipo diploide de $M$. longiaristatum é mais relacionado ao subclado $\mathrm{F}$, enquanto o citótipo poliploide $(2 \mathrm{n}=24)$ ao subclado G.

Observações a campo e em casa de vegetação mostraram que os citótipos diploides de $M$. bifarium e $M$. longiaristatum distinguem-se dos citótipos poliploides quanto à forma de crescimento. O citótipo poliploide de M. bifarium possui hábito de crescimento estolonífero, com os nós basais bastante ramificados, produzindo perfilhos o ano inteiro, assim como $M$. chaseae e $M$. compressum que pertencem ao mesmo subclado $\mathrm{H}$, além de lâminas foliares tenras e membranáceas (Ribeiro 2016). Em contrapartida, o citótipo diploide de M. bifarium possui hábito de crescimento ereto e raramente se ramifica. Quando isto ocorre, os ramos são emitidos nos nós superiores, nunca nos basais (Ribeiro 2016). Este tipo de ramificação também acontece em M. elytrochaetum, espécie estreitamente relacionada. O citótipo poliploide de $M$. longiaristatum possui hábito de crescimento decumbente, enquanto que o citótipo diploide é uma planta essencialmente ereta. Diferenças morfológicas relacionadas ao hábito de crescimento/nível de ploidia já foram observadas em outras gramíneas, especialmente no gênero Paspalum (Parodi 1948, Vaio et al. 2005, Cidade et al. 2013).

O clado E demonstra M. ansatum (M. sect. Bifaria) como grupo irmão do clado formado por espécies que compunham M. sect. Loliiformia (Filgueiras 1989): M. loliiforme, M. arenarium, M. comatum, M. annuum e M. chlorostachyum. Em todas as árvores geradas (Figuras 1, 2 e 3), este grupo de espécies está representado numa grande politomia com pouca resolução internamente. As espécies de hábito anual, M. annuum $(2 \mathrm{n}=8)$ e $M$. chlorostachyum $(2 \mathrm{n}=8)$ mostram ser mais 
relacionadas entre si do que com as espécies que apresentam hábito de vida perene. Mesosetum loliiforme é a espécie de mais ampla distribuição, maior polimorfismo e com maior número de citótipos conhecidos no gênero, apresentando três níveis de ploidia: $2 \mathrm{n}=16,2 \mathrm{n}=24$ e $2 \mathrm{n}=32$ cromossomos. Espécies com diferentes citótipos são frequentemente encontradas em outras Poaceae, formando um complexo agâmico (Brugnoli et al. 2014, Cidade et al. 2013, Zilli et al. 2014). Em Mesosetum, ainda não se sabe qual a origem desses diferentes citótipos, necessitando-se de mais estudos que analisem diferentes populações dessas espécies do ponto de vista genético, reprodutivo e citológico. Filgueiras (1989) colocou sob a sinonímia de M. loliiforme oito espécies anteriormente descritas por Swallen (1937) com base no comprimento, largura e pilosidade das lâminas foliares e tamanho do antécio. Não foi observada nenhuma correspondência entre os distintos citótipos de M. loliiforme com a morfologia de seus sinônimos.

As relações evolutivas entre as três linhagens (Clado $\mathrm{x}=10$, Clado $\mathrm{x}=13$, Clado $\mathrm{x}=4$ ) acima descritas ainda não estão totalmente claras. A linhagem com número cromossômico básico x =10, compartilha com outros gêneros de Paspaleae, além do número cromossômico básico $\mathrm{x}=10$, cromossomos e genomas menores (Morrone et al. 2006, Leitch et al. 2010, Sede et al. 2010, Galdeano et al. 2016, Ribeiro 2016).

A origem das linhagens com número cromossômico básico $\mathrm{x}=4 \mathrm{e} \mathrm{x}=13$ é incerta. A ausência de registros dos números cromossômicos $2 \mathrm{n}=8,16,24,32$ ou ainda $2 \mathrm{n}=26$ em outros gêneros da subtribo Arthropogoninae dificulta a compreensão sobre a origem e evolução destes números cromossômicos. Por isso, estudos posteriores com aumento da amostragem de populações e espécies de Arthropogoninae, que utilizem caracterização cromossômica (bandeamento, morfologia do cariótipo, hibridização in situ) associados ao incremento de novos marcadores moleculares devem ser incentivados.

Keratochlaena rigidifolia (Filg., Morrone \& Zuloaga) Morrone \& Zuloaga foi incluída no gênero Mesosetum nas análises de psbA-trnH (Anexo 3). A estreita relação entre Mesosetum e Keratochlaena já foi relatada em outros estudos que utilizaram tanto marcadores moleculares 
(ndhF, rpoC2) como morfológicos (Sede et al. 2009, Morrone et al. 2012, Silva et al. 2015b). Keratochlaena é um gênero monoespecífico, segregado de Streptostachys (Sede et al. 2009, sob Sclerochlamys) com apenas uma exsicata de herbário disponível além do material tipo (V 8432 $C E N)$. Tendo em vista que somente uma região foi amplificada e sequênciada, mais esforços precisam ser investidos na recoleta desta espécie e na análise de outras regiões do genoma para uma compreensão mais acurada do clado Keratochlaena-Mesosetum-Tatianyx.

Neste trabalho, também pode ser evidenciada a monofilia do gênero Homolepis, o qual teve amostragem de quatro, em um total de cinco espécies atualmente aceitas no gênero (Shirasuna et al. 2017). Este resultado corrobora o resultado encontrado por Morrone et al. (2012). Em todas as árvores filogenéticas geradas, podem ser vistos dois clados: um formado por $H$. glutinosa (Sw.) Zuloaga \& Soderstr., espécie que apresenta espiguetas elipsoides a obovadas; e o outro composto pelas espécies $H$. aturensis (Kunth) Chase, H. isocalycia (G. Mey.) Chase e H. longispicula (Döll) Chase, que possuem espiguetas caracteristicamente lanceoladas.

A aparente falta de resolução interna em alguns clados dentro de Mesosetum pode indicar que a evolução do gênero é muito recente para ser resolvida usando apenas essas regiões de DNA. O presente trabalho demonstrou que apesar de seu modo distinto de herança, os marcadores utilizados foram satisfatórios para inferir relacionamentos em alguns taxa e distinguir as principais linhagens de Mesosetum. Estudos que incluam novas espécies da subtribo Arthropogoninae, principalmente Keratochlaena rigidifolia, e até mesmo da tribo Paspaleae, associados a uma maior amostragem de cpDNA, tanto de regiões codificantes como não codificadoras, e a inclusão de regiões nucleares de cópia única, que exibem variação considerável devem ser estimulados. 


\section{Referências}

Aliscioni, S.S., Giussani, L.M., Zuloaga, F.O. \& Kellogg, E.A. (2003) A molecular phylogeny of Panicum (Poaceae: Paniceae): tests of monophyly and phylogenetic placement within the Panicoideae. American Journal of Botany 90: 796-821.

Álvarez, I. \& Wendel, J.F. (2003) Ribosomal ITS sequences and plant phylogenetic inference. Molecular Phylogenetics and Evolution 29: 417-434.

Avraham, S., Jiang, S., Ota, S., Fu, Y., Deng, B., Dowler, L.L., White, R.A. \& Avraham H. (1995) Structural and Functional Studies of the Intracellular Tyrosine Kinase MATK Gene and Its Translated Product. The Journal of Biological Chemistry 270(4): 1833-1842.

Borchsenius, F. (2009) FastGap 1.2. Software distributed by the authors at (http://www.aubot.dk/FastGap_home.htm).

Brugnoli, E.A., Urbani, M.H., Quarin, C.L., Zilli, A.L., Martínez, E.J. \& Acuña, C.A. (2014) Diversity in Apomictic Populations of Paspalum simplex Morong. Crop Science 54: 16561664.

Cidade, F.W, Vigna, B.B.Z, Souza, F.H.D., Valls, J.F.M., Dall'Agnol, M., Zucchi, M.I., SouzaChies, T.T. \& Souza, A.P. (2013) Genetic variation in polyploid forage grass: Assessing the molecular genetic variability in the Paspalum genus. Genetics 14: 50.

Clayton, W.D. \& Renvoize, S.A. (1986) Genera Graminum: Grasses of the World. Kew Bulletin Additional Series 13, Royal Botanical Garden, Kew, London. 389 pp.

Doyle, J.J. \& Doyle, J.L. (1987) A rapid DNA isolation procedure for small quantities of fresh leaf tissue. Phytochemistry Bulletin 19: 11-15.

Duvall, M.R., Noll, J.D. \& Minn, A.H. (2001) Phylogenetics of Paniceae (Poaceae). American Journal of Botany 88: 1988-1992.

Farris, J.S., Källersjö, M., Kluge, A.G., Bult, C. (1995) Testing significance of incongruence. Cladistics 10: 315-319. 
Felsenstein, J. (1985) Confidence limits on phylogenies: an approach using the bootstrap. Evolution 39: 783-791.

Filgueiras, T.S. (1986) O gênero Mesosetum Steudel (Gramineae: Paniceae). Tese de Doutorado. Universidade Estadual de Campinas, Campinas, 344 pp.

Filgueiras, T.S. (1989) Revisão de Mesosetum Steudel (Gramineae: Paniceae). Acta Amazônica 19: $47-114$.

Galdeano, F., Urbani, M.H., Sartor, M.E., Honfi, A.I., Espinoza, F. \& Quarín, C.L. (2016) Relative DNA content in diploid, polyploid, and multiploid species of Paspalum (Poaceae) with relation to reproductive mode and taxonomy. Journal of Plant Research 129 (4): 697-710.

Giussani, L.M., Cota-Sanchez, H., Zuloaga, F.O. \& Kellogg, E.A. (2001) A molecular phylogeny of the grass subfamily Panicoideae (Poaceae) shows multiple origins of C4 photosynthesis. American Journal of Botany 88: 1993-2012.

Gómez-Martínez, R. \& Culham, A.(2000) Phylogeny of the subfamily Panicoideae with emphasis on the tribe Paniceae: evidence from the trnL-F cpDNA region. In S. Jacobs and J. Everett (Ed.), Grasses, systematics and evolution, CSIRO, Collingwood, Victoria, Australia pp 136140.

Gould, F.W. \& Soderstrom, T.R. (1967) Chromosome numbers of tropical American grasses. American Journal of Botany 54: 676-683.

Grass Phylogeny Working Group (GPWG) (2011) New grass phylogeny resolves deep evolutionary relationships and discovers $\mathrm{C}_{4}$ origins. New Phytologist 193: 304-312.

Hidalgo, M.I.M., Caponio, I. \& Normann, G.A. (2007) Citogenética y biología reproductiva de Anthaenantia lanata (Poaceae: Panicoideae). Kurtziana 33(2): 27-33

Katoh, K. \& Standley, D.M. (2013) MAFFT Multiple Sequence Alignment Software Version 7: Improvements in Performance and Usability. Molecular Biology and Evolution 30(4): 772780.

Kuntze, O. (1898) Revisio Genera Plantarum. Leipzig 3(2), 576 pp. 
Leitch, I.J., Beaulieu, J.M., Chase, M.W., Leitch, A.R. \& Fay, M.F. (2010) Genome Size Dynamics and Evolution in Monocots. Journal of Botany: 1-18.

Meirelles, A.C.S., Monteiro, E.R., Silva, L.A.C., Silva, D., Santos, S.A., Oliveira-Collet, S.A., Mangolin, C.A. \& Machado, M.F.P.S. (2015) Esterase polymorphism for genetic diversity analysis of some accessions of a native forage grass, Mesosetum chaseae Luces, from the Brazilian Pantanal. Tropical Grasslands 3: 194-204.

Miller, M.A., Pfeiffer, W. \& Schwartz, T. (2010) "Creating the CIPRES Science Gateway for inference of large phylogenetic trees" in Proceedings of the Gateway Computing Environments Workshop (GCE), New Orleans, LA pp 1-8.

Morrone, O. \& Zuloaga, F.O. (1991) Revision del género Streptostachys (Poaceae-Panicoideae), su posicion sistematica dentro de la tribu Paniceae. Annals of the Missouri Botanical Garden 78: $359-376$.

Morrone, O., Hunziker, J.H., Zuloaga, F.O. \& Escobar, A. Números cromosómicos en Paniceae Sudamericanas (Poaceae, Panicoideae). Darwiniana 33: 53-60.

Morrone, O., Escobar, A. \& Zuloaga, F.O. (2006) Chromosome Studies in American Panicoideae (Poaceae). Annals of the Missouri Botanical Garden 93(4): 647-657.

Morrone, O., Scataglini, M.A \& Zuloaga, F.O. (2007) Cyphonanthus, a New Genus Segregated from Panicum (Poaceae: Panicoideae: Paniceae) Based on Morphological, Anatomical and Molecular Data. Taxon 56 (2): 521-532.

Morrone, O. \& Zuloaga, F.O. (2009) Keratochlaena, el nombre correcto para Sclerochlamys (Poaceae, Paniceae). Darwiniana 47: 231.

Morrone, O., Aagesen, L., Scataglini, M.A., Salariato, D.L., Denham, S., Chemisquy, M.A., Sede, S.M., Giussani, L.M., Kellogg, E.A. \& Zuloaga, F.O. (2012) Phylogeny of the Paniceae (Poaceae: Panicoideae): integrating plastid DNA sequences and morphology into a new classification. Cladistics $1-24$. 
Oliveira, R.P., Clark, L.G., Schnadelbach, A.S., Monteiro, S.H.N., Borba, E.L., Longhi-Wagner, H.M. \& van den Berg, C. (2014) A molecular phylogeny of Raddia and its allies within the tribe Olyreae (Poaceae, Bambusoideae) based on noncoding plastid and nuclear spacers. Molecular Phylogenetics and Evolution 78: 105-117.

Parodi, L. R. (1948) Gramíneas Argentinas nuevas o críticas. I. La variación en Paspalum notatum Flügge. Revista Argentina de Agronomia 15: 53-57.

Pohl, R.W. \& Davidse, G. (1971) Chromosome numbers of Costa Rican grasses. Brittonia 23: $293-$ 324.

Ramirez, M.J. (2006) Further problems with the incongruence length difference test: “hypercongruence” effect and multiple comparisons. Cladistics 22: 289-295.

Ribeiro, A.R.O. (2013) Citogenética, reprodução e variabilidade morfológica de espécies de Mesosetum sect. Bifaria (Hack.) Chase (Poaceae: Paspaleae). Dissertação de Mestrado.Universidade de Brasília, Brasília-DF, 111 pp.

Ribeiro, A.R.O., Sousa, M.W.S., Oliveira, R.C., Araujo, A.C.G., Fagg, C.W. \& Pozzobon, M.T. (2015) Cytological studies in four species of Mesosetum (Arthropogoninae) reveal the lowest chromosome number among the Neotropical Poaceae. Plant Systematics and Evolution 301: 2377-2386.

Ribeiro, A.R.O. (2016) Estudos cromossômicos e reprodutivos em espécies de Mesosetum Steud. (Poaceae: Paspaleae). Tese de Doutorado. Universidade de Brasília, Brasília-DF, 116 pp.

Ronquist, F. \& Huelsenbeck, J.P. (2003) MrBayes 3: Bayesian phylogenetic inference under mixed models. Bioinformatics 19: 1572-1574.

Sánchez-Ken, J.G. \& Clark, L.G. (2010) Phylogeny and a new tribal classification of the Panicoideae s.l. (Poaceae) based on plastid and nuclear sequence data and structural data. American Journal of Botany 97: 1732-1748.

Sang, T., Crawford, D.J. \& Stuessy, T.F. (1997) Chloroplast DNA phylogeny, reticulate evolution and biogeography of Paeonia (Paeoniaceae). American Journal of Botany 84: 1120-1136. 
Scataglini, M.A., Zuloaga, F.O., Giussani, L.M., Denham, S.S. \& Morrone, O. (2014) Phylogeny of New World Paspalum (Poaceae, Panicoideae, Paspaleae) based on plastid and nuclear markers. Plant Systematics and Evolution 300: 1051-1070.

Sede, S.M., Morrone, O., Giussani, L.M. \& Zuloaga, F.O. (2008) Phylogenetic studies in the Paniceae (Poaceae): a realignment of section Lorea of Panicum. Systematic Botany 33: 284300.

Sede, S.M., Morrone, O., Aliscioni, S.S., Giussani, L.M. \& Zuloaga, F.O. (2009) Oncorachis and Sclerochlamys, two new segregated genera from Streptostachys (Poaceae, Panicoideae, Paniceae): a revision based on molecular, morphological and anatomical characters. Taxon 58: $365-374$.

Sede, S., Escobar, A., Morrone, O. \& Zuloaga, F.O. (2010) Chromosome Studies in American Paniceae (Poaceae, Panicoideae). Annals of the Missouri Botanical Garden 97 (1): 128-138.

Shirasuna, R.T.,Oliveira, R.C. \& Silva, A.S. (2017) Homolepis in Lista de Espécies da Flora do Brasil. Jardim Botânico do Rio de Janeiro. Disponivel em: <http://floradobrasil.jbrj.gov.br/jabot/floradobrasil/FB13261>. Acesso em: 20 Jan. 2017.

Silva, L.A.C., Pagliarini, M.S., Santos, S.A., Silva, N. \& Souza, V.F. (2012) Chromosome number, microsporogenesis, microgametogenesis, and pollen viability in the Brazilian native grass Mesosetum chaseae (Poaceae). Genetics and Molecular Research 11: 4100-4109.

Silva, C., Snak, C., Schnadelbach, A.S., van den Berg, C. \& Oliveira, R.P. (2015a) Phylogenetic relationships of Echinolaena and Ichnanthus within Panicoideae (Poaceae) reveal two new genera of tropical grasses. Molecular Phylogenetics and Evolution 93: 212-233.

Silva, A.S., Ribeiro, A.R.O., Sousa, M.W.S., Fagg, C.W., Falcão, R. \& Oliveira, R.C. (2015b) Micromorphology of the upper anthecium in Mesosetum Steud. and related genera (Poaceae, Arthropogoninae) and its taxonomic applications. Rodriguésia 66: 645-657. 
Silva, A.S., Villarroel, D., Ribeiro, A.R.O. \& Oliveira, R.C. (2016) Eleven new records of little known taxa of Mesosetum and Paspalum (Poaceae) from Brazil and Bolivia. Phytotaxa 268 (1): 069-079.

Sousa, M.W.S. (2014) Citogenética e morfologia de espécies de Mesosetum Steud. (Poaceae, Paspaleae). Dissertação de Mestrado.Universidade de Brasília, Brasília-DF. 76 pp.

Stamatakis, A., (2006) RAxML-VI-HPC: maximum likelihood-based phylogenetic analyses with thousands of taxa and mixed models. Bioinformatics 22: 2688-2690.

Storchová, H., Hrdličková, R., Chrtek, J.Jr., Tetera, M., Fitze, D. \& Fehrer, J. (2000) An Improved Method of DNA Isolation from Plants Collected in the Field and Conserved in Saturated NaCl/CTAB Solution. Taxon 49: 79-84.

Sugita, M., Shinozaki, K. \& Sugiura, M. (1985) Tobacco chloroplast tRNALys (UUU) gene contains a 2.5-kilobase-pair intron: an open reading frame and a conserved boundary sequence in the intron. Proceedings of the National Academy of Sciences 82: 3557-3561.

Swallen, J.R. (1937) The grass genus Mesosetum. Brittonia 2: 363-392.

Swofford, D.L. (2003) PAUP/. Phylogenetic analysis using parsimony (and other methods), version 4.0b10. Sinauer, Sunderland, Massachusetts, USA.

Taberlet, P., Gielly, L., Pautou, G. \& Bouvet, J. (1991) Universal primers for amplification of three non-coding regions of chloroplast DNA. Plant Molecular Biology 17: 1105-1109.

Thiers, B. (2017; continuously updated) Index Herbariorum: A global directory of public herbaria and associated staff. New York Botanical Garden's Virtual Herbarium. Available from: http://sweetgum.nybg.org/ih/ (acesso em 20/01/2017).

Townsend, C.R., Costa, N.L. \& Pereira, R.G.A. (2012) Pastagens Nativas na Amazônia Brasileira, Documentos 149. Embrapa, Porto Velho, 25 pp.

Vaio, M., Speranza, P., Valls, J.F.M., Guerra, M. \& Mazzella, C. (2005) Localization of the 5S and 45S rDNA Sites and cpDNA Sequence Analysis in Species of the Quadrifaria Group of Paspalum (Poaceae, Paniceae). Annals of Botany 96: 191-200. 
van den Berg, C., Goldman, D.H., Freudenstein, J.V., Pridgeon, A.M., Cameron, K.M. \& Chase, M.W., (2005) An overview of the phylogenetic relationships within Epidendroideae inferred from multiple DNA regions and recircumscription of Epidendreae and Arethuseae (Orchidaceae). American Journal of Botany 92: 613-624.

White, T.J., Bruns, T., Lee, S. \& Taylor, J. (1990) Amplification and direct sequencing of fungal ribosomal RNA genes for phylogenetics. In: Innis, M.A., Gelfand, D.H., Sninsky, J.J. \& White, T.J. (Eds) PCR Protocols: A Guide to Methods and Applications, Academic Press Inc., San Diego, pp. 315-322.

Zilli, A.L., Hojsgaard, D.H., Brugnoli, E.A., Acuña, C.A., Honfi, A.I., Urbani, M.H., Quarin, C.L. \& Martinez, E.J. (2014) Genetic relationship among Paspalum species of the subgenus Anachyris: Taxonomic and evolutionary implications. Flora 209: 604-612.

Zuloaga, F.O., Morrone, O. \& Giussani, L. (2000) A cladistic analysis of the Paniceae: a preliminary approach. In S. Jacobs and J. Everett (Ed.), Grasses, systematics and evolution, CSIRO, Collingwood, Victoria, Australia pp 123-135.

Zuloaga, F.O., Giussani, L.M. \& Morrone, O. (2007) Hopia, a new monotypic genus segregated from Panicum (Poaceae). Taxon 56: 145-156.

Zuloaga, F.O., Scataglini, M.A. \& Morrone, O. (2010) A phylogenetic evaluation of sects. Agrostoidea, Megista, Prionitia and Tenera of Panicum (Panicoideae, Poaceae): two new genera Stephostachys and Sorengia. Taxon 59: 1535-1546. 
Capítulo 2

Sinopse do gênero Mesosetum Steud. (Poaceae, Paspaleae) e novas combinações 


\section{Capítulo 2}

Sinopse do gênero Mesosetum Steud. (Poaceae, Paspaleae) e novas combinações

\section{Introdução}

Antes de Steudel (1854) descrever Mesosetum, suas espécies eram relacionadas a Panicum L., em diferentes seções dentro deste gênero. Trinius (1826) agrupou $P$. ferrugineum Trin. e $P$. exaratum Trin. - ambas atualmente aceitas como Mesosetum - juntamente com P. rarum R. Br.atualmente Setaria rara (R. Br.) R.D. Webster - num dos quatro subgrupos de Panicum sect. Jubaria Trin. O agrupamento foi baseado em dois caracteres "Ramos floríferos simplíssimos, espiguetas alternas". Nees (1829) criou Panicum sect. Loliacea e agrupou todas as espécies até então conhecidas e atualmente consideradas Mesosetum: P. eriochrysoides Nees (atualmente $M$. ferrugineum), $P$. pappophorum Nees e $P$. exaratum.

Trinius (1834) criou Panicum sect. Harpostachys e usou como diagnose "Racemos simplíssimos, solitários, espiguetas subsésseis" agrupando as espécies $P$. ansatum Trin., $P$. exaratum, $P$. eriochrysoides, $P$. rottboellioides Kunth e $P$. sclerochloa Trin - todas atualmente consideradas Mesosetum. Além dessas espécies, nesta seção também foram incluídas outras espécies de Panicum, as quais, atualmente, pertencem aos gêneros Paspalum L. subgen. Harpostachys (Trin.) S. Denham e Echinolaena Desv.

Steudel (1854) descreveu o gênero Mesosetum com base apenas em M. cayennense, embora já estivessem descritas várias espécies de Panicum que se encaixavam no seu novo gênero, como $P$. ansatum, P. ferrugineum, P. rottboellioides e P. sclerochloa. Estas espécies foram mantidas sob Panicum sect. Harpostachys, o qual ainda relacionou o novo gênero a Panicum mesocomum Nees, espécie africana que apresenta a pilosidade das glumas semelhante aos tufos de tricomas encontrados em algumas espécies de Mesosetum. 
Mesmo após a descrição de Mesosetum (Steudel 1854), alguns autores não aceitaram o novo gênero e continuaram a tratar as espécies sob Panicum, talvez pela inconsistência da descrição de Steudel (Filgueiras 1986). Assim, Döll (1877) descreveu novas espécies de Mesosetum e as colocou sob Panicum sect. Harpostachys. Já Bentham \& Hooker (1883) agruparam as espécies de Mesosetum em seções distintas. Incluíram M. cayennense sob Panicum sect. Trichachne (Nees) Steud., juntamente com outras espécies que, atualmente, pertencem aos gêneros Alloteropsis J. Presl, Digitaria L. e Eriachne R. Br., e agruparam em Panicum sect. Diplaria Benth. \& Hook, somente espécies que hoje são consideradas Mesosetum: $P$. exaratum, $P$. ferrugineum, $P$. pappophorum e P. rottboellioides. É notável a reincidência de $P$. rottboellioides em grupo distinto de M. cayennense (Steudel 1854) por serem espécies tão relacionadas morfologicamente que já foram consideradas sinônimos (Hitchcock 1909, Chase 1911).

Hackel (1897) descreveu três novas espécies de Mesosetum sob Panicum - P. bifarium Hack., P. caudiculatum Hack. e P. elytrochaetum Hack. e as agrupou em Panicum sect. Bifaria Hack. Kuntze (1898) elevou Panicum sect. Bifaria a gênero com a espécie B. bifaria (Hack.) Kuntze, mostrando que o trabalho de Steudel (1854) fora esquecido.

Em 1909, 55 anos após Steudel (1854) propor o gênero, Mesosetum começou a ser aceito. Hitchcock (1909) descreveu M. wrightii Hitchc., transferiu Panicum rottboellioides para Mesosetum e sinonimizou $M$. cayennense a $M$. rottboellioides. Chase (1911) fez a primeira descrição completa e clara para o gênero, propôs cinco novas combinações e constituiu as seções Mesosetum sect. Mesosetum e M. sect. Bifaria (Hack.) Chase.

A primeira revisão taxonômica para Mesosetum foi feita por Swallen (1937), que reconheceu 33 espécies, descreveu 15 novos táxons, fez duas novas combinações e dividiu o gênero em seis seções: $M$. sect. Annua Swallen, M. sect. Bifaria, M. sect. Fulva Swallen, M. sect. Loliiformia Swallen, M. sect. Penicillata Swallen e M. sect. Sclerochloae Swallen. Neste trabalho, Swallen (1937) também sinonimizou o gênero monoespecífico Peniculus Swallen à Mesosetum, descrito pelo mesmo autor em 1932. Pilger (1940) aceitou 30 espécies, no entanto, nominou apenas 
sete e subdividiu o gênero em três seções: $M$. sect. Bifaria, $M$. sect. Eumesosetum Pilg. e $M$. sect. Sclerochloae.

Na última revisão taxonômica, Filgueiras $(1986,1989)$ reconheceu 25 espécies, publicou três novas espécies e aceitou apenas seis das quinze novas espécies descritas por Swallen (1937), sinonimizando as demais. Agrupou as espécies de Mesosetum em cinco seções. A seção Annua foi incluída em Loliiformia e a seção Fulva, por conter a espécie tipo do gênero, teve o nome corrigido para Mesosetum. Apenas uma das cinco seções de Mesosetum propostas por Filgueiras (1989) é monofilética $(M$. sect. Mesosetum, Clado x =10). As demais seções mostraram-se parafiléticas com pelo menos um representante distribuídos em cada um dos três maiores clados descritos no Capítulo 1 desta tese. Portanto, a maioria das seções propostas anteriormente por Swallen (1937) e Filgueiras (1989) não reflete agrupamentos naturais.

Mesosetum é um gênero com distribuição predominantemente Neotropical, ocorre desde o sul do México até o nordeste da Argentina. O Brasil detém o maior número de espécies do gênero, das 26 espécies aceitas neste trabalho, 22 são registradas no território brasileiro. Duas novas ocorrências foram recentemente registradas para a flora brasileira e uma espécie adicionada para a flora da Bolívia (Silva et al. 2016, Capítulo 5).

As espécies de Mesosetum ocupam, preferencialmente, ambientes campestres e savânicos. Análises anatômicas evidenciam que o mecanismo fotossintético é C4 (Filgueiras 1986, Giussani et al. 2001, GPWG 2011).

Para se propor uma hipótese filogenética de Mesosetum, foi feita uma ampla revisão de herbários, onde havia um número superior de coletas desde a última revisão e novas coletas foram efetuadas ao longo deste trabalho. Com a inclusão de Tatianyx em Mesosetum, a ampliação da área de ocorrência conhecida e análise de maior quantidade de material botânico, e a descrição de uma nova espécie (Capítulo 3), verificou-se a necessidade de compilar as adições ao conhecimento do grupo. Desta forma, esta Sinopse traz a descrição atualizada do gênero Mesosetum, uma nova chave de identificação que engloba a amplitude de variação morfológica atualmente conhecida, 
distribuição geográfica atualizada dos táxons, comentários taxonômicos e nomenclaturais, preferências ecológicas e ilustração de espécies de Mesosetum.

\section{Metodologia}

Foram realizadas expedições de coleta em diferentes estados do Brasil no período de março de 2012 a fevereiro de 2016 com o objetivo de ampliar o conhecimento biológico e geográfico das espécies de Mesosetum. As técnicas de coleta e herborização foram conforme Fidalgo \& Bononi (1989). As exsicatas foram depositadas no herbário UB (acrônimo em Thiers, continuously updated) e duplicatas distribuídas a herbários congêneres. Muitas espécies de Mesosetum estão sendo cultivadas na Estação Biológica da UnB e em casa de vegetação na Embrapa/Cenargen, e foram observadas para adicionar dados biológicos das espécies.

Além das novas coleções, foram analisados espécimens provenientes de empréstimos dos herbários BHCB, BHZB, BOTU, CAY, CEN, CESJ, COR, EAC, EPAMIG, ESA, ESAL, FLOR, FUEL, FURB, HEPH, HRB, HRCB, HTINS, HUEFS, HUFU, HXBH, IAN, IBGE, ICN, INPA, JPB, MBM, MEXU, MG, MOSS, MPEG, PEUFR, R, RBR, SI, SMDB, SP, SPF, TEPB, UB, UFMT, UFRN, USZ, VASF e VEN (acrônimos em Thiers, continuously updated). Todo o material tipo das 25 espécies de Mesosetum foi analisado em visitas aos herbários europeus B, BM, K, L, P, OXF e W, durante o período de doutorado sanduíche da autora. Quando não houve a possibilidade de analisar os espécimes-tipo, comparações foram feitas com base nas imagens disponíveis no PlantsJSTOR.

Foram fotografados pelo menos um exemplar de cada espécie estudada em uma câmera acoplada a um esteromicroscópio Leica EZ4D e as fotos tratadas com o software Adobe Photoshop versão 7.0.

A análise morfológica foi realizada no laboratório de Fanerógamas do Herbário UB (Departamento de Botânica/UnB) e no Herbário K (Royal Botanic Garden, Kew). As características 
analisadas foram baseadas na análise dos trabalhos de Swallen (1937) e Filgueiras (1989). Os carateres não previamente descritos por Swallen (1937) e Filgueiras (1989) foram incluídos na Tabela 1. Os termos de caracteres e estados de caracteres seguiram a nomenclatura usada em Radford (1974).

O material selecionado representa as novas coleções, os novos registros de ocorrência e os espécimes que apresentam ampliação da variação morfológica anteriormente conhecida.

\section{Resultados e Discussão}

As análises de herbários aliadas às expedições de campo touxeram novidades acerca do conhecimento morfológico das espécies de Mesosetum. Todas as 25 espécies e sinonímias propostas por Filgueiras (1989) são aceitas neste trabalho. Junta-se a elas, a inclusão de Tatianyx em Mesosetum e uma nova espécie descrita no Capítulo 3 desta tese. Uma nova descrição para o gênero Mesosetum, com a ampliação da sua circunscrição é proposta. Também são fornecidos uma nova chave de identificação das espécies e comentários taxonômicos.

As caraterísticas incluídas na Tabela 1 foram úteis para a distinção das espécies de Mesosetum e por isso utilizadas nas descrições dos táxons. Esses carateres auxiliaram a compor a chave de identificação das espécies do gênero. Muitas dessas características foram especialmente importantes para distinguir espécies muito relacionadas morfologicamente, tais como a inserção da espigueta no pedicelo em $M$. alatum e $M$. bifarium, a forma do ápice e a ornamentação do antécio em M. annuum e M. pappophorum, presença de estolhos e disposição dos tricomas das espiguetas em M. cayennense e M. rottboellioides, tricomas de base tuberculada e antécio membranáceo em $M$. exaratum e $M$. filifolium, entre outros. 
Tabela 1. Carateres morfológicos úteis para a distinção das espécies de Mesosetum Steud.

\begin{tabular}{|c|c|c|c|c|c|}
\hline Espécie/Carater & Hábito & $\begin{array}{l}\text { Estolhos: } \\
\text { presença / } \\
\text { ausência }\end{array}$ & $\begin{array}{c}\text { Estolhos: } \\
\text { orientação de } \\
\text { crescimento }\end{array}$ & $\begin{array}{c}\text { Colmo: } \\
\text { Disposição } \\
\text { das folhas }\end{array}$ & $\begin{array}{l}\text { Lâminas } \\
\text { foliares }\end{array}$ \\
\hline $\begin{array}{c}\text { Mesosetum agropyroides } \\
\text { Mez }\end{array}$ & perene & ausentes & não observados & basais & planas \\
\hline Mesosetum alatum Filg. & perene & presentes & $\begin{array}{c}\text { emitidos } \\
\text { verticalmente }\end{array}$ & caulinares & planas \\
\hline $\begin{array}{c}\text { Mesosetum annuum } \\
\text { Swallen }\end{array}$ & anual & ausentes & não observados & caulinares & planas \\
\hline $\begin{array}{l}\text { Mesosetum ansatum } \\
\text { (Trin.) Chase }\end{array}$ & perene & presentes & $\begin{array}{l}\text { emitidos } \\
\text { horizontalmente }\end{array}$ & caulinares & planas \\
\hline $\begin{array}{c}\text { Mesosetum arenarium } \\
\text { Swallen }\end{array}$ & perene & ausentes & não observados & caulinares & planas \\
\hline $\begin{array}{c}\text { Mesosetum arnacites } \\
\text { (Trin.) A.S. Silva \& } \\
\text { R.C. Oliveira }\end{array}$ & perene & ausentes & não observados & basais & $\begin{array}{l}\text { planas a } \\
\text { convolutas }\end{array}$ \\
\hline $\begin{array}{l}\text { Mesosetum bifarium } \\
\text { (Hack.) Chase }\end{array}$ & perene & presentes & $\begin{array}{c}\text { emitidos } \\
\text { horizontalmente }\end{array}$ & caulinares & $\begin{array}{l}\text { planas a } \\
\text { convolutas }\end{array}$ \\
\hline $\begin{array}{l}\text { Mesosetum blakei } \\
\text { Swallen }\end{array}$ & perene & ausentes & não observados & basais & planas \\
\hline $\begin{array}{c}\text { Mesosetum cayennense } \\
\text { Steud. }\end{array}$ & perene & ausentes & não observados & caulinares & planas \\
\hline $\begin{array}{c}\text { Mesosetum chaseae } \\
\text { Luces }\end{array}$ & perene & presentes & $\begin{array}{c}\text { emitidos } \\
\text { horizontalmente }\end{array}$ & caulinares & planas \\
\hline $\begin{array}{c}\text { Mesosetum } \\
\text { chlorostachyum (Döll) } \\
\text { Chase }\end{array}$ & anual & ausentes & não observados & caulinares & planas \\
\hline $\begin{array}{c}\text { Mesosetum comatum } \\
\text { Swallen }\end{array}$ & perene & ausentes & não observados & caulinares & planas \\
\hline $\begin{array}{c}\text { Mesosetum compressum } \\
\text { Swallen }\end{array}$ & perene & presentes & $\begin{array}{l}\text { emitidos } \\
\text { horizontalmente }\end{array}$ & caulinares & planas \\
\hline $\begin{array}{c}\text { Mesosetum } \\
\text { elytrochaetum (Hack.) } \\
\text { Swallen }\end{array}$ & perene & presentes & $\begin{array}{c}\text { emitidos } \\
\text { verticalmente }\end{array}$ & caulinares & aciculares \\
\hline $\begin{array}{l}\text { Mesosetum exaratum } \\
\text { (Trin.) Chase }\end{array}$ & perene & ausentes & não observados & basais & aciculares \\
\hline Mesosetum ferrugineum & perene & ausentes & não observados & caulinares & planas a \\
\hline
\end{tabular}




\begin{tabular}{|c|c|c|c|c|c|}
\hline (Trin.) Chase & & & & & convolutas \\
\hline $\begin{array}{c}\text { Mesosetum filifolium } \\
\text { F.T. Hubb. }\end{array}$ & perene & ausentes & não observados & basais & aciculares \\
\hline $\begin{array}{c}\text { Mesosetum gibbosum } \\
\text { Renvoize \& Filg. }\end{array}$ & perene & ausentes & não observados & caulinares & planas \\
\hline $\begin{array}{c}\text { Mesosetum loliiforme } \\
\text { (Hochst. ex Steud.) } \\
\text { Chase }\end{array}$ & perene & presentes & $\begin{array}{l}\text { emitidos } \\
\text { horizontalmente }\end{array}$ & caulinares & $\begin{array}{c}\text { planas a } \\
\text { convolutas }\end{array}$ \\
\hline $\begin{array}{c}\text { Mesosetum } \\
\text { longiaristatum Filg. }\end{array}$ & anual & ausentes & não observados & caulinares & planas \\
\hline $\begin{array}{c}\text { Mesosetum } \\
\text { pappophorum (Nees) } \\
\text { Kuhlm. }\end{array}$ & anual & ausentes & não observados & caulinares & planas \\
\hline $\begin{array}{c}\text { Mesosetum penicillatum } \\
\text { Mez }\end{array}$ & perene & ausentes & não observados & basais & planas \\
\hline $\begin{array}{l}\text { Mesosetum pittieri } \\
\text { Hitchc. }\end{array}$ & anual & ausentes & não observados & basais & planas \\
\hline $\begin{array}{c}\text { Mesosetum } \\
\text { rottboellioides (Kunth) } \\
\text { Hitchc. }\end{array}$ & perene & presentes & $\begin{array}{c}\text { emitidos } \\
\text { verticalmente }\end{array}$ & basais & planas \\
\hline $\begin{array}{l}\text { Mesosetum sclerochloa } \\
\text { (Trin.) Hitchc. }\end{array}$ & anual & ausentes & não observados & basais & planas \\
\hline Mesosetum sp. nov. 1 & anual & ausentes & não observados & basais & planas \\
\hline $\begin{array}{c}\text { Mesosetum wrightii } \\
\text { Hitchc. }\end{array}$ & perene & presentes & $\begin{array}{l}\text { emitidos } \\
\text { horizontalmente }\end{array}$ & & planas \\
\hline
\end{tabular}


Continuação... Tabela 1. Carateres morfológicos úteis para a distinção das espécies de Mesosetum Steud.

\begin{tabular}{|c|c|c|c|c|c|}
\hline Espécie/Carater & $\begin{array}{c}\text { Ráquis: } \\
\text { terminando } \\
\text { em }\end{array}$ & Ráquis & $\begin{array}{l}\text { Pedicelo: } \\
\text { ápice }\end{array}$ & $\begin{array}{l}\text { Espigueta: } \\
\text { Compressão }\end{array}$ & $\begin{array}{c}\text { Espigueta: } \\
\text { cor dos } \\
\text { tricomas }\end{array}$ \\
\hline
\end{tabular}

\begin{tabular}{cccccc}
\hline $\begin{array}{c}\text { Mesosetum agropyroides } \\
\text { Mez }\end{array}$ & espigueta & não alada & truncado & dorsal & alvos \\
$\begin{array}{c}\text { Mesosetum alatum } \text { Filg. } \\
\begin{array}{c}\text { Mesosetum annuum } \\
\text { Swallen }\end{array}\end{array}$ & espigueta & alada & oblíquo & lateral & alvos \\
$\begin{array}{c}\text { Mesosetum ansatum } \\
\text { (Trin.) Chase }\end{array}$ & espigueta & alada & truncado & lateral & alvos \\
$\begin{array}{c}\text { Mesosetum arenarium } \\
\text { Swallen }\end{array}$ & espigueta & não alada & truncado & dorsal & alvos \\
\hline
\end{tabular}

\section{Mesosetum arnacites}

(Trin.) A.S. Silva \& R.C. espigueta não alada oblíquo dorsal alvos Oliveira

\begin{tabular}{|c|c|c|c|c|c|}
\hline $\begin{array}{l}\text { Mesosetum bifarium } \\
\text { (Hack.) Chase }\end{array}$ & espigueta & alada & truncado & lateral & alvos \\
\hline $\begin{array}{l}\text { Mesosetum blakei } \\
\text { Swallen }\end{array}$ & espigueta & não alada & truncado & dorsal & alvos \\
\hline $\begin{array}{c}\text { Mesosetum cayennense } \\
\text { Steud. }\end{array}$ & espigueta & não alada & truncado & dorsal & $\begin{array}{l}\text { castanhos a } \\
\text { ferrugíneos }\end{array}$ \\
\hline $\begin{array}{c}\text { Mesosetum chaseae } \\
\text { Luces }\end{array}$ & espigueta & alada & truncado & lateral & alvos \\
\hline $\begin{array}{c}\text { Mesosetum } \\
\text { chlorostachyum (Döll) } \\
\text { Chase }\end{array}$ & espigueta & não alada & truncado & dorsal & glabra \\
\hline $\begin{array}{c}\text { Mesosetum comatum } \\
\text { Swallen }\end{array}$ & espigueta & não alada & truncado & dorsal & alvos \\
\hline $\begin{array}{c}\text { Mesosetum compressum } \\
\text { Swallen }\end{array}$ & espigueta & alada & truncado & lateral & alvos \\
\hline $\begin{array}{l}\text { Mesosetum elytrochaetum } \\
\text { (Hack.) Swallen }\end{array}$ & espigueta & alada & truncado & lateral & alvos \\
\hline $\begin{array}{l}\text { Mesosetum exaratum } \\
\text { (Trin.) Chase }\end{array}$ & espigueta & não alada & truncado & dorsal & alvos \\
\hline $\begin{array}{c}\text { Mesosetum ferrugineum } \\
\text { (Trin.) Chase }\end{array}$ & espigueta & não alada & oblíquo & dorsal & $\begin{array}{l}\text { castanhos a } \\
\text { ferrugíneos }\end{array}$ \\
\hline
\end{tabular}




\section{Mesosetum filifolium F.T.} Hubb.

espigueta

não alada

truncado

dorsal

alvos

Mesosetum gibbosum Renvoize \& Filg.

espigueta

não alada

Mesosetum loliiforme (Hochst. ex Steud.) Chase espigueta não alada truncado dorsal alvos

Mesosetum longiaristatum Filg. espigueta alada truncado lateral alvos

\section{Mesosetum pappophorum} (Nees) Kuhlm.

espigueta

não alada

truncado

dorsal

alvos

\section{Mesosetum penicillatum} Mez

espigueta

não alada

truncado

dorsal

alvos

Mesosetum pittieri Hitchc.

espigueta

alada

truncado

lateral

alvos

Mesosetum rottboellioides

(Kunth) Hitchc.

espigueta não alada oblíquo

dorsal

castanhos a

Mesosetum sclerochloa (Trin.) Hitchc. espigueta alada truncado lateral ferrugíneos

Mesosetum sp. nov. 1 ápice
meristemático não alada oblíquo dorsal castanhos a

\section{Mesosetum wrightii} Hitchc. 
Continuação... Tabela 1. Carateres morfológicos úteis para a distinção das espécies de Mesosetum Steud.

\begin{tabular}{|c|c|c|c|}
\hline Espécie/Carater & $\begin{array}{l}\text { Gluma inferior e } \\
\text { superior: nervuras } \\
\text { anastomosadas }\end{array}$ & $\begin{array}{c}\text { Lema inferior: distribuição dos } \\
\text { tricomas }\end{array}$ & $\begin{array}{l}\text { Antécio } \\
\text { superior: } \\
\text { ápice }\end{array}$ \\
\hline $\begin{array}{c}\text { Mesosetum agropyroides } \\
\text { Mez }\end{array}$ & não & $\begin{array}{c}\text { tricomas de base tuberculada, } \\
\text { distribuídos ao longo das } \\
\text { nervuras }\end{array}$ & agudo \\
\hline Mesosetum alatum Filg. & não & $\begin{array}{l}\text { tricomas de base não tuberculada, } \\
\text { apenas no terço distal }\end{array}$ & agudo \\
\hline $\begin{array}{c}\text { Mesosetum annuum } \\
\text { Swallen }\end{array}$ & não & $\begin{array}{c}\text { tricomas de base não tuberculada, } \\
\text { distribuídos ao longo das } \\
\text { nervuras laterais }\end{array}$ & agudo \\
\hline $\begin{array}{l}\text { Mesosetum ansatum } \\
\text { (Trin.) Chase }\end{array}$ & não & $\begin{array}{c}\text { tricomas de base não tuberculada, } \\
\text { distribuídos ao longo das } \\
\text { nervuras laterais }\end{array}$ & acuminado \\
\hline $\begin{array}{c}\text { Mesosetum arenarium } \\
\text { Swallen }\end{array}$ & não & $\begin{array}{c}\text { tricomas de base não tuberculada, } \\
\text { distribuídos ao longo das } \\
\text { nervuras laterais }\end{array}$ & acuminado \\
\hline $\begin{array}{c}\text { Mesosetum arnacites } \\
\text { (Trin.) A.S. Silva \& R.C. } \\
\text { Oliveira }\end{array}$ & não & $\begin{array}{l}2 \text { tufos de tricomas de base não } \\
\text { tuberculada no terço distal }\end{array}$ & agudo \\
\hline $\begin{array}{l}\text { Mesosetum bifarium } \\
\text { (Hack.) Chase }\end{array}$ & não & $\begin{array}{l}2 \text { tufos de tricomas de base não } \\
\text { tuberculada no terço distal }\end{array}$ & acuminado \\
\hline $\begin{array}{l}\text { Mesosetum blakei } \\
\text { Swallen }\end{array}$ & não & $\begin{array}{c}\text { tricomas de base não tuberculada, } \\
\text { distribuídos ao longo das } \\
\text { nervuras laterais }\end{array}$ & acuminado \\
\hline $\begin{array}{l}\text { Mesosetum cayennense } \\
\text { Steud. }\end{array}$ & não & $\begin{array}{c}\text { tricomas de base não tuberculada, } \\
\text { distribuídos ao longo das } \\
\text { nervuras laterais }\end{array}$ & agudo \\
\hline $\begin{array}{c}\text { Mesosetum chaseae } \\
\text { Luces }\end{array}$ & não & $\begin{array}{c}\text { tricomas de base não tuberculada, } \\
\text { distribuídos ao longo das } \\
\text { nervuras laterais }\end{array}$ & agudo \\
\hline $\begin{array}{c}\text { Mesosetum } \\
\text { chlorostachyum (Döll) } \\
\text { Chase }\end{array}$ & não & glabro & acuminado \\
\hline $\begin{array}{c}\text { Mesosetum comatum } \\
\text { Swallen }\end{array}$ & não & $\begin{array}{c}\text { tricomas de base tuberculada, } \\
\text { distribuídos ao longo das } \\
\text { nervuras laterais }\end{array}$ & agudo \\
\hline Mesosetum compressum & não & 2 tufos de tricomas de base não & agudo \\
\hline
\end{tabular}




\begin{tabular}{|c|c|c|c|}
\hline Swallen & & tuberculada no terço distal & \\
\hline $\begin{array}{c}\text { Mesosetum } \\
\text { elytrochaetum (Hack.) } \\
\text { Swallen }\end{array}$ & não & $\begin{array}{l}2 \text { tufos de tricomas de base não } \\
\text { tuberculada no terço distal }\end{array}$ & agudo \\
\hline $\begin{array}{l}\text { Mesosetum exaratum } \\
\text { (Trin.) Chase }\end{array}$ & não & $\begin{array}{l}2 \text { tufos de tricomas de base } \\
\text { tuberculada no terço distal }\end{array}$ & agudo \\
\hline $\begin{array}{c}\text { Mesosetum ferrugineum } \\
\text { (Trin.) Chase }\end{array}$ & não & $\begin{array}{c}\text { tricomas de base não tuberculada, } \\
\text { distribuídos ao longo das } \\
\text { nervuras laterais }\end{array}$ & agudo \\
\hline $\begin{array}{c}\text { Mesosetum filifolium } \\
\text { F.T. Hubb. }\end{array}$ & não & $\begin{array}{c}\text { tricomas de base não tuberculada, } \\
\text { distribuídos ao longo das } \\
\text { nervuras laterais }\end{array}$ & agudo \\
\hline $\begin{array}{l}\text { Mesosetum gibbosum } \\
\text { Renvoize \& Filg. }\end{array}$ & não & $\begin{array}{l}2 \text { tufos de tricomas de base não } \\
\text { tuberculada no terço distal }\end{array}$ & agudo \\
\hline $\begin{array}{c}\text { Mesosetum loliiforme } \\
\text { (Hochst. ex Steud.) } \\
\text { Chase }\end{array}$ & não & $\begin{array}{c}\text { tricomas de base não tuberculada, } \\
\text { distribuídos ao longo das } \\
\text { nervuras laterais }\end{array}$ & agudo \\
\hline $\begin{array}{c}\text { Mesosetum } \\
\text { longiaristatum Filg. }\end{array}$ & não & $\begin{array}{l}2 \text { tufos de tricomas de base não } \\
\text { tuberculada no terço distal }\end{array}$ & agudo \\
\hline $\begin{array}{c}\text { Mesosetum pappophorum } \\
\text { (Nees) Kuhlm. }\end{array}$ & sim & $\begin{array}{l}2 \text { tufos de tricomas de base não } \\
\text { tuberculada no terço distal }\end{array}$ & apiculado \\
\hline $\begin{array}{c}\text { Mesosetum penicillatum } \\
\text { Mez }\end{array}$ & não & $\begin{array}{l}2 \text { tufos de tricomas de base } \\
\text { tuberculada no terço distal }\end{array}$ & agudo \\
\hline $\begin{array}{l}\text { Mesosetum pittieri } \\
\text { Hitchc. }\end{array}$ & $\operatorname{sim}$ & $\begin{array}{l}1 \text { tufo de tricomas de base não } \\
\text { tuberculada no terço distal }\end{array}$ & acuminado \\
\hline $\begin{array}{l}\text { Mesosetum rottboellioides } \\
\text { (Kunth) Hitchc. }\end{array}$ & não & $\begin{array}{c}\text { tricomas de base não tuberculada, } \\
\text { distribuídos ao longo das } \\
\text { nervuras laterais }\end{array}$ & agudo \\
\hline $\begin{array}{l}\text { Mesosetum sclerochloa } \\
\text { (Trin.) Hitchc. }\end{array}$ & sim & $\begin{array}{l}1 \text { tufo de tricomas de base não } \\
\text { tuberculada no terço distal }\end{array}$ & acuminado \\
\hline Mesosetum sp. nov. 1 & não & $\begin{array}{c}\text { tricomas de base não tuberculada, } \\
\text { distribuídos ao longo das } \\
\text { nervuras laterais }\end{array}$ & agudo \\
\hline $\begin{array}{c}\text { Mesosetum wrightii } \\
\text { Hitchc. }\end{array}$ & não & $\begin{array}{l}1 \text { tufo de tricomas de base não } \\
\text { tuberculada no terço distal }\end{array}$ & agudo \\
\hline
\end{tabular}




\section{Tratamento Taxonômico}

Mesosetum Steud. Synopsis Plantarum Glumacearum 1: 118. 1854. $\equiv$ Panicum sect. Jubata Trin. De Graminibus Paniceis 159. 1826. 三 Panicum sect. Loliacea Nees. Flora Brasiliensis seu Enumeratio Plantarum 2(1): 102. 1829. 三 Panicum sect. Diplaria Benth. \& Hook. Genera Plantarum 3(2): 1101. 1883. 三 Panicum sect. Bifaria Hack. Oesterreichische Botanische Zeitschrift 47(3): 75-76. 1897. 三 Bifaria (Hack.) Kuntze. Revisio Generum Plantarum 3: 359. 1898. $\equiv$ Peniculus Swallen. American Journal of Botany 19: 581. 1932. $\equiv$ Tatianyx Zuloaga \& Soderstr. Smithsonian Contributions to Botany 59: 56-60. 1985.

Tipo:-Mesosetum cayennense Steud.

Plantas anuais ou perenes; rizomas ausentes ou presentes; colmos eretos, decumbentes ou estoloníferos. Lâminas foliares planas, convolutas ou aciculares, glabras ou vilosas. Inflorescências terminais. Ráquis encerrando em espigueta desenvolvida ou em desenvolvimento. Espiguetas solitárias dispostas em inflorescências racemiformes ou paniculiformes; inseridas em pedicelos com ápice truncado ou oblíquo; dorsiventral ou lateralmente comprimidas; pilosas ou raramente glabras (M. chlorostachyum), tricomas alvos, ferrugíneos ou vináceos. Glumas inferiores adaxiais à raquis; múticas a aristadas; com ou sem tufos de tricomas; planas ou conduplicadas. Glumas superiores lanceoladas; com ou sem tufos de tricomas. Antécios inferiores masculinos ou neutros. Lemas inferiores com tricomas ao longo das nervuras laterais ou com tufos de tricomas no dorso, raramente glabros ( $M$. chlorostachyum). Páleas inferiores presentes ou ausentes. Antécios superiores hermafroditas; membranáceos a coriáceos; ápice fechado. Cariopse com hilo linear. 


\section{Chave de identificação das espécies de Mesosetum}

1. Espiguetas solitárias dispostas em ramos paniculiformes

M. arnacites

1'. Espiguetas solitárias dispostas em ramos unilaterais racemiformes 2

2. Espiguetas com compressão lateral ..............................................................................

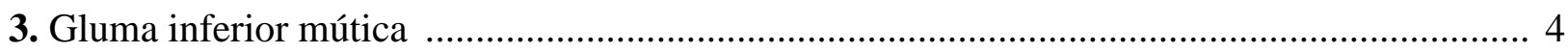

4. Plantas perenes. Ráquis $2,2-5,2 \mathrm{~mm}$ de larg., convoluta, encobrindo de $2 / 3$ a totalmente as espiguetas

M. ansatum

4'. Plantas anuais. Ráquis 1,0-1,5 mm de larg., plana, não encobrindo as espiguetas .5

5. Gluma inferior mais curta que o antécio M. sclerochloa

5'. Gluma inferior mais longa que o antécio M. pittieri

3'. Gluma inferior aristada ou mucronada 6

6. Lâminas cilíndricas, coriáceas. Ráquis coriácea M. elytrochaetum

6'. Lâminas planas, membranáceas ou cartáceas. Ráquis membranácea 7

7. Plantas anuais, não estoloníferas. Espiguetas maduras com uma glândula intumescente na base M. longiaristatum 7'. Plantas perenes, estoloníferas. Espiguetas maduras sem glândula intumescente na base .8

8. Ráquis convoluta, encobrindo em $2 / 3$ a totalmente as espiguetas. Anteras alvas a amarelas M. ansatum

8'. Ráquis plana, não encobrindo as espiguetas. Anteras vináceas 9

9. Ráquis até $1,5 \mathrm{~mm}$ larg. Gluma inferior mucronada ou com arista de até $1,0 \mathrm{~mm}$ compr. M. chaseae 9'. Ráquis com mais de 2,0 mm larg. Gluma inferior aristada, arista maior que 2,0 mm de compr. 10

10. Espiguetas com pedicelos oblíquos voltados para a região mediana da rá- 
quis; espiguetas inseridas obliquamente no pedicelo formando um calo de aparência geniculada (Fig. 1a) M. alatum

$\mathbf{1 0}^{\prime}$. Espiguetas com pedicelo plano; espiguetas inseridas perpendicularmente no pedicelo, sem formação de calo (Fig. 1b)

11. Lâminas foliares lineares, planas a convolutas, 1-3 mm larg., margem escabra. Gluma superior com um tufo de tricomas no dorso

M. bifarium

11'. Lâminas foliares lanceoladas, planas, nunca convolutas, 3-6 mm larg., margem com tricomas espaçados, com base tuberculada. Gluma superior com dois tufos de tricomas no dorso M. compressum

2'. Espiguetas com compressão dorsal 12

12. Espiguetas pilosas, tricomas castanhos a ferrugíneos, raro amarelo pálido 13

13. Gluma inferior com ápice truncado ou retuso, com dois tufos de tricomas na região mediana. Gluma superior com dois tufos de tricomas no dorso na região distal M. cayennense 13'. Gluma inferior com ápice arredondado, agudo ou acuminado, tricomas distribuídos uniformemente ao longo das margens. Gluma superior sem tufos de tricomas, tricomas distribuídos uniformemente no dorso 14

14. Plantas anuais. Ráquis terminando num meristema Mesosetum sp. nov. 1

14'. Plantas perenes. Ráquis terminando numa espigueta 15 15. Bainhas proximais tornando-se fibrosas quando velhas. Gluma inferior da mesma largura da espigueta. Antécio 4-5 mm de compr. M. ferrugineum 15'. Bainhas proximais inteiras. Gluma inferior mais estreita que a espigueta. Antécio 3-3,5 mm de compr. M. rottboellioides

12'. Espiguetas glabras ou quando pilosas, os tricomas alvos a esverdeados ou vináceos, nunca castanhos ou amarelo pálido 16

16. Plantas anuais 17 
17. Espiguetas unisseriadas, glabrescentes M. chlorostachyum

17'. Espiguetas bisseriadas, pilosas 18

18. Gluma inferior e lema inferior com nervuras anastomosadas no terço distal. Antécio liso rostrado (Fig. 1c) M. pappophorum 18'. Gluma inferior e lema inferior sem nervuras anastomosadas. Antécio papiloso, não rostrado (Fig. 1d) M. annuum

16'. Plantas perenes 17

19. Lâminas aciculares 20

20. Gluma inferior inflada na região distal, assimétrica M. loliiforme

20'. Gluma inferior plana, simétrica 21

21. Gluma superior com dorso densamente piloso. Lema inferior com tufos de tricomas de base tuberculada. Antécio cartáceo M. exaratum 21'. Gluma superior com tricomas apenas nas margens. Lema inferior com tufos de tricomas de base não tuberculada. Antécio membranáceo M. filifolium

19'. Lâminas planas 22

22. Espiguetas com tricomas de base tuberculada na gluma inferior e/ou gluma superior e/ou lema inferior 23

23. Folhas a maioria basais. Gluma inferior com tricomas de base não tuberculada na metade inferior. Gluma superior e lema inferior com tricomas de base tuberculada concentra dos na região mediana M. penicillatum $\mathbf{2 3}^{\prime}$. Folhas caulinares. Gluma inferior com uma linha de tricomas de base tuberculada na metade inferior. Gluma superior e lema inferior com tricomas uniformemente distribuídos no dorso ou apenas nas margens 24

24. Espiguetas 3,5-4,0 mm de compr. Gluma inferior assimétrica. Gluma superior com tricomas distribuídos apenas nas margens, ápice agudo 
24'. Espiguetas 5,0-7,0 mm de compr. Gluma inferior simétrica. Gluma superior com tricomas distribuídos uniformemente no dorso, ápice naviculado

M. agropyroides

22'. Espiguetas com tricomas de base não tuberculada na gluma inferior e/ou gluma superior e/ou lema inferior

25. Plantas formando estolhos no florescimento. Gluma inferior conspicuamente menor que a gluma superior

26. Espiguetas pilosas. Gluma inferior assimétrica. Gluma superior 5-nervada..

M. loliiforme

26'. Espiguetas glabrescentes. Gluma inferior simétrica. Gluma superior 7-9nervada M. wrightii

25'. Plantas nunca estoloníferas. Glumas subiguais

27. Gluma inferior estreitada na base, ápice crestado (nervura central com uma expansão prolongada no dorso) (Fig. 1e) M. arenarium

27'. Gluma inferior não estreitada na base, ápice agudo 28

28. Gluma superior 3-nervada. Antécio 4-5 mm de compr., ápice agudo

M. gibbosum

28'. Gluma superior 5-7-nervada. Antécio 3-4 mm de compr., ápice apiculado M. blakei 

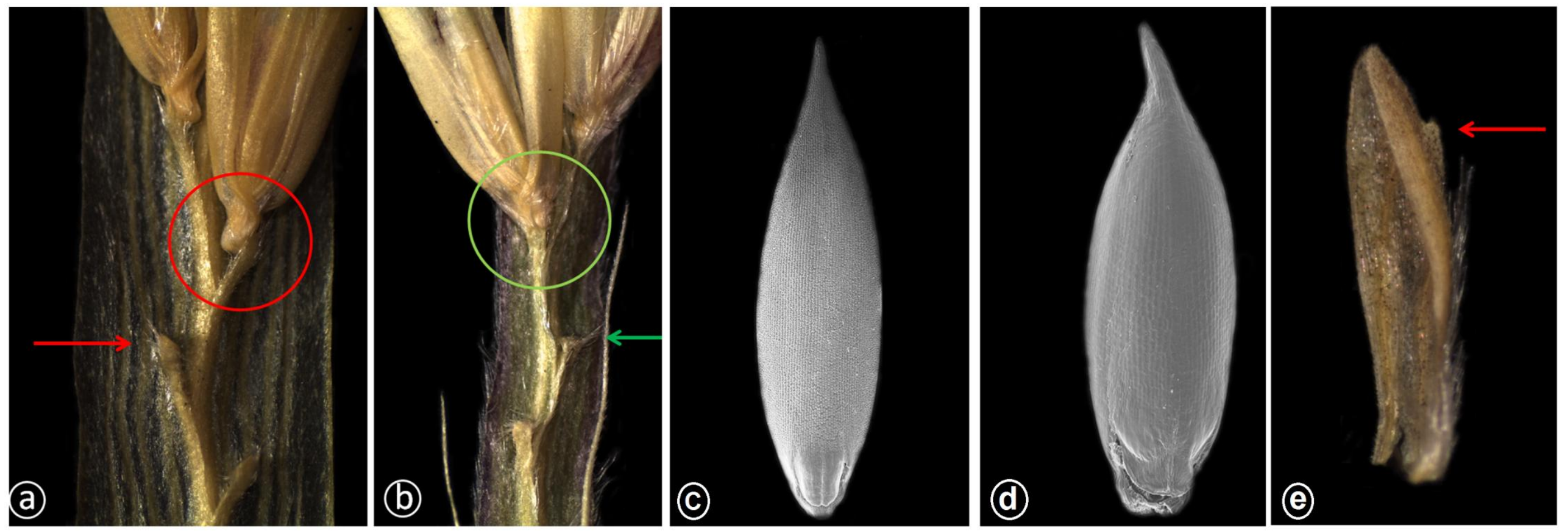

Figura 1. Estados de carater: a-Mesosetum alatum Filg., pedicelos oblíquos voltados para a região mediana da ráquis (seta) e espiguetas inseridas obliquamente no pedicelo formando um calo com aparência geniculada (círculo), R.C. Oliveira 2765 (UB). b-M. bifarium (Hack.) Chase, ápice do pedicelo plano (seta) e espiguetas inseridas perpendicularmente no pedicelo (círculo), A.S. Silva 235 (UB). c-Mesosetum annuum Swallen, antécio papiloso e ápice acuminado, A.S. Silva 270 (UB). d-M. pappophorum (Nees) Kuhlm, antécio liso e ápice curvo, A.S. Silva 267 (UB). e-M. arenarium Swallen, ápice crestado-nervura central com uma expansão prolongada no dorso (seta), T.S. Filgueiras 1098 (UB). 
1. Mesosetum agropyroides Mez, Repertorium Specierum Novarum Regni Vegetabilis 15: 125. 1918. Fig. 2a

Tipo:-Brasil, Goiás, 31 Ago 1895, Glaziou 22452 (holótipo B!, isótipos BM!, K!, P!, S, US[foto!]).

Plantas perenes; cespitosas; rizomas presentes; estolhos ausentes. Folhas a maioria basais, dispostas na base do colmo. Lâminas foliares planas; membranáceas; lanceoladas; glabras a densamente pilosas em ambas as superfícies, ciliadas, tricomas com ou sem base tuberculada. Inflorescências terminais; ráquis encerrando em espigueta desenvolvida, não aladas, 0,5-0,8 mm larg. Espiguetas solitárias dispostas em inflorescências racemiformes; 5,0-7,0 × 3,0-3,5 mm; inseridas em pedicelos com ápice truncado, ca $1 \mathrm{~mm}$ de compr.; dorsiventralmente comprimidas; pilosas, tricomas alvos. Glumas inferiores $3,8-5,0 \times 1,5-2,0 \mathrm{~mm}, 3-5$-nervadas, nervuras encontrando-se na região distal; simétricas; pilosas no terço proximal, tricomas de base tuberculada, ápice naviculado; múticas. Glumas superiores 5,0-7,0 × 1,5-2,0 mm; 5-nervadas, nervuras encontrando-se na região distal; pilosas no terço distal; múticas. Antécios inferiores masculinos. Lemas inferiores com tricomas de base tuberculada, distribuídos ao longo das nervuras; nervuras encontrando-se na região distal. Páleas inferiores presentes. Antécios superiores 4,4-4,8 × 1,42,0 mm, coriáceos, ápice agudo; anteras vináceas.

As descrições disponíveis de M. agropyroides (Mez 1918; Swallen 1937; Filgueiras 1989) foram baseadas em análises de apenas duas coletas de Glaziou em 1895, sem localização exata: "Fields of Pichoa", "Rocky Mountains of Guariroba" e "Between Siriaco and Guariroba". Segundo Filgueiras (1989), essas localidades provavelmente ficam situadas próximas a Goiás Velho (Goiás) e o mesmo empenhou esforços para recoletá-la, sem sucesso. As escassas informações acerca desta espécie trazem a imagem de tratar-se de uma espécie rara. A revisão dos herbários brasileiros revelou a ocorrência de $M$. agropyroides em mais dois estados: São Paulo e Paraná (Silva et al. 
2016, Capítulo 5). É possível que com maior esforço de coleta, possam ser acrescidas novas coleções dessa espécie em herbários.

Mesosetum agropyroides pode ser reconhecido pelas suas espiguetas longas e densamente pilosas, apresentando uma das maiores espiguetas dentro do gênero, 5-7 $\mathrm{mm}$ de comprimento. E até o presente momento, em todas as exsicatas examinadas há indícios de que a espécie floresce após o fogo, por causa da ausência de lâminas foliares e bainhas foliares carbonizadas.

A ocorrência de M. agropyroides reportada para a Bolívia por Renvoize (1998) e Jørgensen et al. (2014) não foi confirmada. Após análise minuciosa do material citado (St.G. Beck 2068-USZ e J.R.I. Wood et al. 27037-USZ) concluiu-se que se trata de M. penicillatum Mez (Fig.2b), a qual distingue-se de $M$. agropyroides por apresentar espiguetas menores (4,0-5,5 mm compr.) e pela pilosidade das glumas e lema inferior. Mesosetum agropyroides possui tricomas de base tuberculada uniformemente distribuídos no dorso da gluma superior, enquanto que M. penicillatum apresenta apenas um tufo de tricomas na gluma superior e lema inferior (Fig. 2a, 2b).

Na hipótese filogenética proposta no capítulo 1, M. agropyroides mostra-se relacionada às espécies do clado $\mathrm{x}=4$. No entanto, ainda não há registro de contagem cromossômica para esta espécie.

Material selecionado:-BRASIL. Goiás: Campos de Pichoa, 5 Ago 1894, Galziou s.n. (K). Paraná: Jaguariaíva, campo próximo a ponte do Rio das Mortes, 16 Dez 1991, A.C. Cervi et al. 3575 (MBM). São Paulo: São Miguel Arcanjo, Dez 1949, J. Vidal III 129 (R).

2. Mesosetum alatum Filg., Brittonia 39(2): 306. 1987. Fig. 1a, 3a

Tipo:-Brasil, Mato Grosso, Serra de Roncador, ca. $14^{\circ} .30 \mathrm{~S} 55^{\circ} .50 \mathrm{~W}$, Xavantina-Cachimbo road, 65 km from Xavantina, 24 May 1966, Hunt \& Ramos 5552 (holótipo UB!, isótipos K!, NY [foto!], SP!). 
Plantas perenes; cespitosas; rizomas ausentes; estolhos presentes, vistos apenas em cultivo, emitidos verticalmente. Folhas a maioria basais, dispostas na base do colmo. Lâminas foliares planas; membranáceas; linear-lanceoladas; glabras em ambas as superfícies, ciliadas, tricomas com ou sem base tuberculada. Inflorescências terminais; ráquis encerrando em espigueta desenvolvida, aladas, 2,2-3,2 mm larg. Espiguetas solitárias dispostas em inflorescências racemiformes; 3,3-4,2 $\times$ 0,6-1,2 $\mathrm{mm}$; inseridas em pedicelos com ápice oblíquo, ca $1 \mathrm{~mm}$ de compr.; lateralmente comprimidas; pilosas, tricomas alvos. Glumas inferiores 3,3-4,2 × 0,6-1,2 $\mathrm{mm}$; 3-nervadas, nervuras encontrando-se na região distal; simétricas; glabras; ápice bidentado; aristadas, aristas 2,5-3,5 $\mathrm{mm}$ de compr. Glumas superiores 3,0-3,8 $\times$ 0,6-1,0 $\mathrm{mm}$; 5-nervadas, nervuras encontrando-se na região distal; glabras, margens ciliadas; múticas. Antécios inferiores masculinos ou neutros. Lemas inferiores com tricomas de base não tuberculada, apenas no terço distal; nervuras encontrando-se na região distal. Páleas inferiores presentes. Antécios superiores 2,5-3,0 × 1,0 mm; cartáceos; ápice agudo; anteras vináceas. 

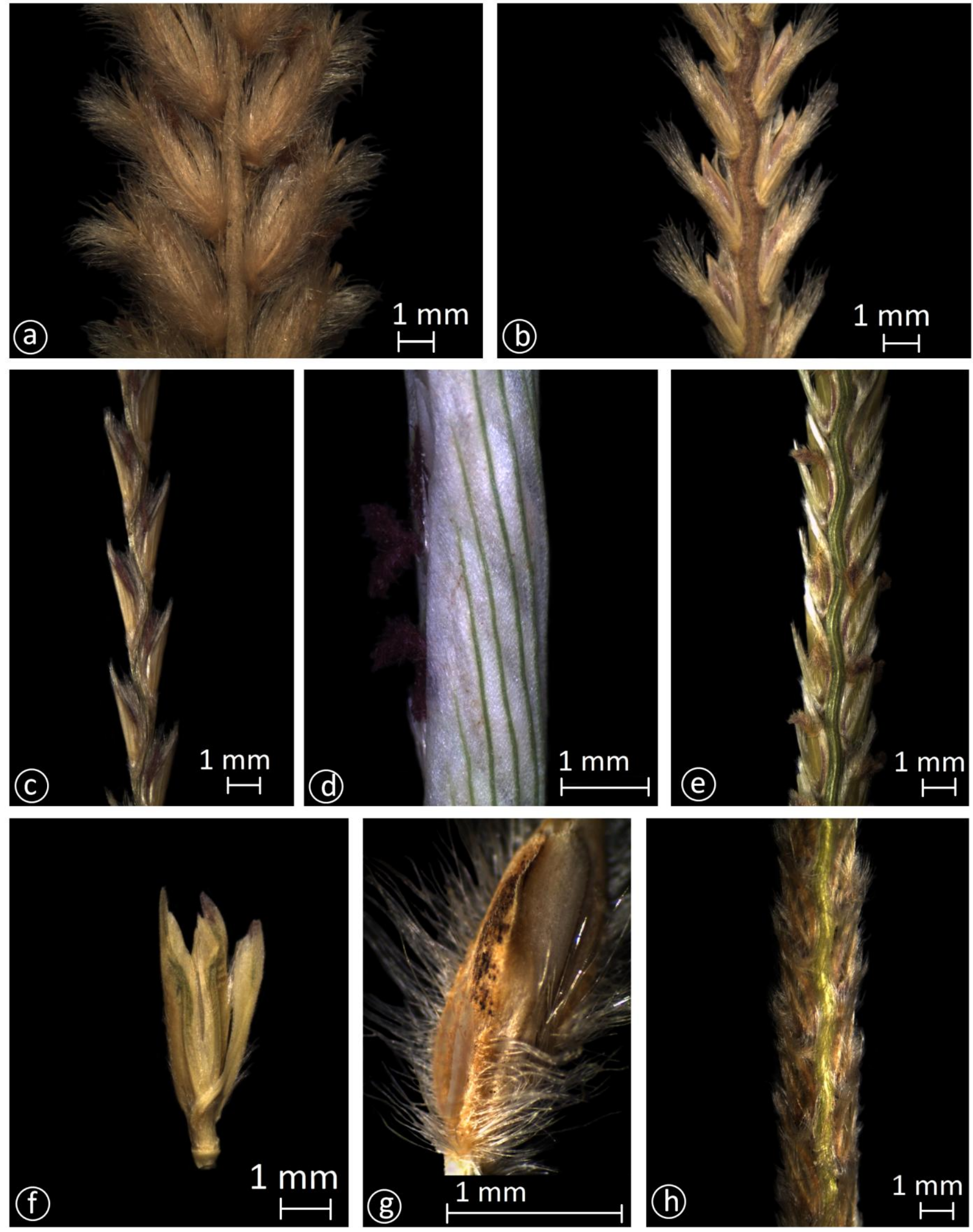

Figura 2. Fotos de espécies de Mesosetum: (a) detalhe da inflorescência de M. agropyroides Mez, J. Vidal III 129 (R); (b) detalhe da inflorescência de M. penicillatum Mez, T.S. Filgueiras et al. 3472 (SP); (c) detalhe da inflorescência de M. filifolium F.T. Hubb., P.L. Viana 3438 (SP); (d) detalhe da inflorescência de M. ansatum (Trin.) Kuhlm., R.C. Oliveira et al. 2766 (UB); (e) detalhe da inflorescência de M. loliiforme (Hochst. ex Steud.) Chase, A.R.O. Ribeiro 425 (UB); (f) espigueta de M. sclerochloa (Trin.) Hitchcock, A.S. Silva 266 (UB); (g) espigueta de M. comatum Swallen, A.R.O. Ribeiro 418 (UB); (h) detalhe da inflorescência de M. comatum, A.R.O. Ribeiro 418 (UB). (Foto: Silva et al. 2016). 
Mesosetum alatum é endêmica do Estado do Mato Grosso, Brasil. É filogeneticamente relacionada a $M$. chaseae, $M$. compressum, $M$. longiaristatum e $M$. bifarium (Capítulo 1). Filgueiras (1989) reconhecia a proximidade morfológica entre essas espécies, por compartilharem a ráquis alada e a gluma inferior aristada. Este mesmo autor apresenta um quadro comparativo destacando os carateres taxonômicos para distinção destes táxons, tais como, ciclo de vida, comprimento e largura da lâmina foliar, comprimento da arista da gluma inferior, presença da arista na gluma superior, presença de tufos de tricomas na gluma superior e a presença de flor no antécio inferior. No entanto, esses carateres mostraram-se variáveis após análise de novas coleções e de materiais sob cultivo.

Mesosetum alatum é distinguida de $M$. chaseae pela largura da ráquis e tamanho da arista da gluma inferior. Em M. alatum a ráquis é mais larga (mais que 2,0 $\mathrm{mm}$ de largura) e a arista maior que 2,0 $\mathrm{mm}$ de comprimento, enquanto que em $M$. chaseae a largura máxima da ráquis é de 1,5 mm e o comprimento da arista da gluma inferior não passa de 1,0 mm. Difere de M. longiaristatum pelo hábito de crescimento. Mesosetum alatum possui hábito de vida perene e estolonífero, enquanto $M$. longiaristatum é uma planta anual, não estolonífera. Já $M$. compressum e $M$. bifarium, assim como M. alatum, são plantas com hábito de vida perene e estolonífera. No entanto, diferem de $M$. alatum principalmente pelo tipo de inserção das espiguetas no pedicelo. Mesosetum alatum é a única das espécies a apresentar pedicelos oblíquos voltados para a região mediana da ráquis, com espiguetas inseridas obliquamente no pedicelo formando um calo com aparência geniculada (Fig. 1a). Enquanto que em $M$. bifarium e $M$. compressum, o ápice do pedicelo é truncado e as espiguetas estão inseridas perpendicularmente no pedicelo, sem formação de calo (Fig. 1b).

É registrado o número cromossômico 2n = 8 para M. alatum (Ribeiro 2016).

Material selecionado:-BRASIL. Mato Grosso: Novo Santo Antônio, Parque Estadual do Araguaia, 12³6'55"S, 5049'23"W, 23 Jul 2006, H.S. Jancosk et al. 8625 (UB); Nova Nazaré, Margem da estrada de Nova Nazaré para Canarana, 1358'59"S, 5148'36"W, 01 Ago 2015, J.E.Q. 
Faria et al. 4947 (HEPH, UB); Água Boa, Direita da rodovia BR 158, no km 599, 14²18'44"S, 52¹0'5.2"W, 24 Mai 2012, R.C. Oliveira 2765 (UB).
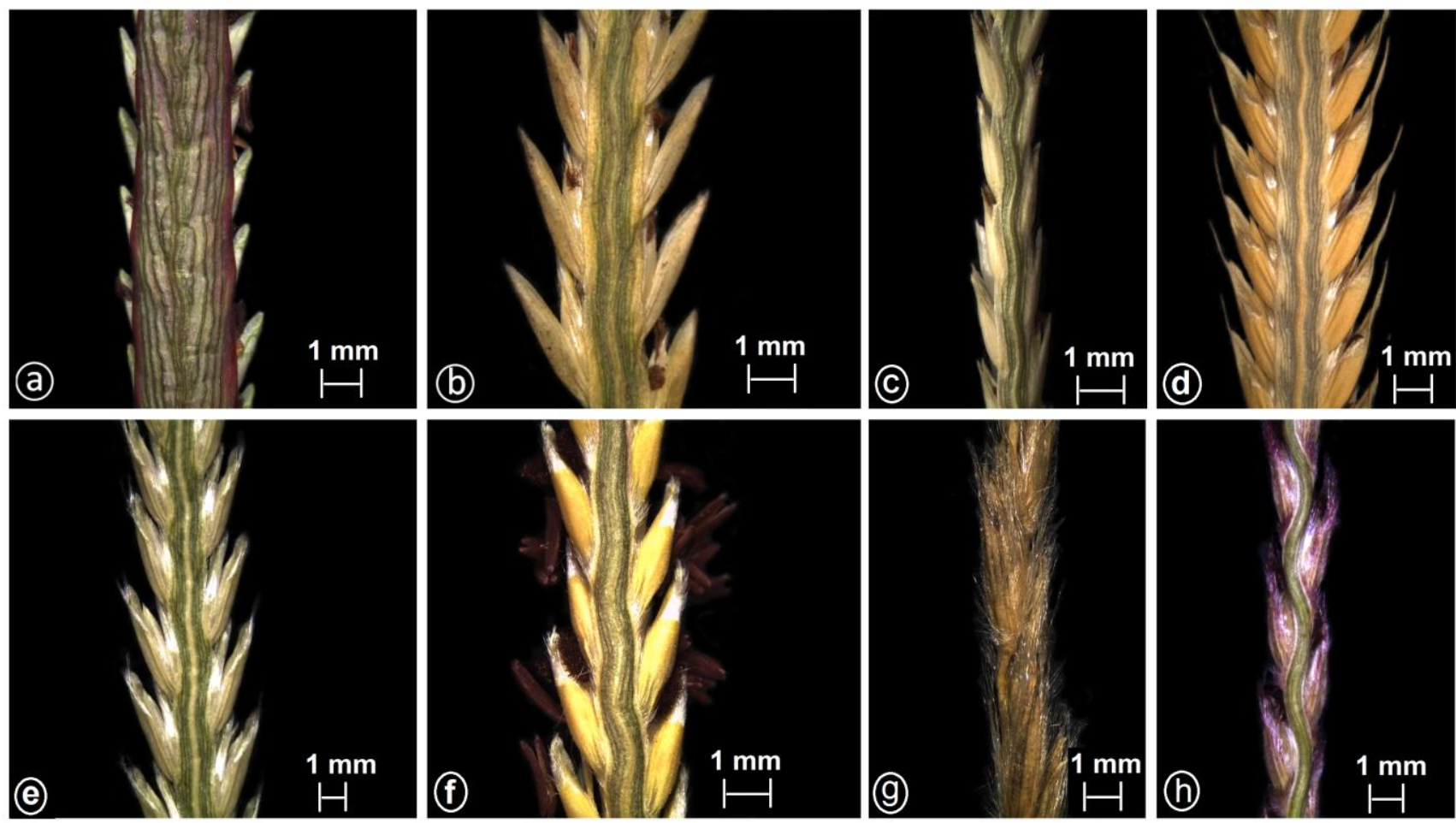

Figura 3. Fotos de espécies de Mesosetum: (a) detalhe da inflorescência de M. alatum Filg., R.C. Oliveira et al. 2765 (UB); (b) detalhe da inflorescência de M. bifarium (Hack.) Chase, A.S. Silva et al. 235 (UB); (c) detalhe da inflorescência de M. chaseae Luces, R.C. Oliveira et al. 2772 (UB); (d) detalhe da inflorescência de M. compressum Swallen, Pinheiro \& Carvalho 438 (IAN); (e) detalhe da inflorescência de M. longiaristatum Filg., R.C. Oliveira et al. 2816 (UB); (f) detalhe da inflorescência de M. elytrochaetum (Hack.) Swallen, R.C. Oliveira et al. 2722 (UB); (g) detalhe da inflorescência de $M$. blakei Swallen, Stevens 8188 (K); (h) detalhe da inflorescência de $M$. pappophorum (Nees) Kuhlm., J.F.M. Valls 15949 (CEN). (Fotos b-f gentilmente cedidas por André R.O. Ribeiro). 
3. Mesosetum annnum Swallen, Brittonia 2(4): 377-378. 1937. Fig. 1c

Tipo:-Brasil, Piauí, on open summit of rocky slope, 3 Abr 1934, J.R. Swallen 4190 (holótipo US1614005[foto!]; isótipos K000004407[foto!], NY00381365[foto!], MG, RB35941[foto!], S).

Sinônimos:-Mesosetum multicaule Swallen, Brittonia 2(4): 378. 1937. Brasil, Maranhão, Grajaú para Porto Franco, 8-13 Mar 1934, J.R. Swallen 3866 (holótipo US-1614006 [foto!]; isótipos MG [foto!], MO-245172 [foto!], NY-381369 [foto!], RB-35932 [foto!]).

Plantas anuais; cespitosas ou decumbentes; rizomas ausentes; estolhos ausentes. Folhas a maioria basais, dispostas na base do colmo. Lâminas foliares planas; membranáceas; lanceoladas; glabras a pilosas, ciliadas, tricomas sem base tuberculada. Inflorescências terminais; ráquis encerrando em espigueta desenvolvida, não aladas, ca 0,3 mm larg. Espiguetas solitárias dispostas em inflorescências racemiformes; 3,5-4,0 × 1,0 mm; inseridas em pedicelos com ápice truncado, ca $1 \mathrm{~mm}$ de compr.; dorsiventralmente comprimidas; pilosas, tricomas alvos. Glumas inferiores 2,8 3,0 × 0,6-1,0 mm; 3-nervadas, nervuras não encontrando-se na região distal; assimétricas; pilosas, tricomas distribuídos apenas no terço proximal; ápice obtuso ou levemente bilobado; múticas. Glumas superiores 2,3-2,5 × 0,6 mm; 3-nervadas, nervuras não encontrando-se na região distal; pilosas, tricomas distribuídos apenas nas margens; múticas. Antécios inferiores neutros. Lemas inferiores com tricomas de base não tuberculada, distribuídos ao longo das nervuras laterais; nervuras não encontrando-se na região distal. Páleas inferiores ausentes. Antécios superiores 2,53,2 × 1,0 mm; cartáceos; ápice agudo; anteras vináceas.

Mesosetum annuum é relacionada a $M$. arenarium, M. chlorostachyum, M. comatum e $M$. loliiforme. São espécies muito próximas do ponto de vista morfológico (Filgueiras 1989), micromorfológico (Silva et al. 2015, Capítulo 4), citológico (Sousa 2014, Ribeiro et al. 2015, Ribeiro 2016) e filogenético (Capítulo 1). Essas espécies compartilham o número cromossômico básico $\mathrm{x}=4$ e apresentam diferentes níveis de ploidia $2 \mathrm{n}=8,2 \mathrm{n}=16,2 \mathrm{n}=24$ e $2 \mathrm{n}=32$ (Sousa 
2014, Ribeiro et al. 2015, Ribeiro 2016), formando um complexo de espécies com muitas características em comum e poucas características exclusivas.

Mesosetum annuum e M. loliiforme distinguem-se apenas pelo hábito de vida, sendo anual em M. annиum e perene em M. loliiforme. Todas as outras características apontadas por Filgueiras (1989) para a distinção dessas espécies mostraram-se variáveis. Já M. chlorostachyum, que também é uma espécie anual, distingue-se de $M$. annuum pela presença/ausência de tricomas, disposição das espiguetas na ráquis e preferência ambiental. Mesosetum chlorostachyum apresenta espiguetas glabras, unisseriadas, e habita solos úmidos em bordas de mata. Enquanto que M. annuum possui espiguetas pilosas, bisseriadas e habita solos secos e ambientes campestres.

Esta espécie era registrada apenas para os estados de Goiás, Maranhão e Piauí, Brasil. A revisão de herbários ampliou a área de ocorrência de $M$. annuum para os estados do Ceará, Minas Gerais, Rio Grande do Norte, Pará e Tocantins. Além disso, foi registrada a ocorrência desta espécie na Guiana.

É registrado o número cromossômico 2n $=8$ para M. annuum (Sousa 2014, Ribeiro et al. 2015).

Material selecionado:-BRASIL. Ceará: Jericoacoara, Jijoca de Jericoacoara, Parque Nacional de Jericoacoara, 253'42"S, 40²6'57"W, 11 Mai 2003, G.F. Lima et al. 395 (EAC, SPF, UEC). Goiás: Flores de Goiás, à 12 km do trevo de flores, lado direito da BR, 21 Mar 2013, P.A. Reis 182 (UB). Maranhão: Barão de Grajaú, 100m a oeste da ponte sobre o Rio Parnaiba na rodovia BR-230 junto

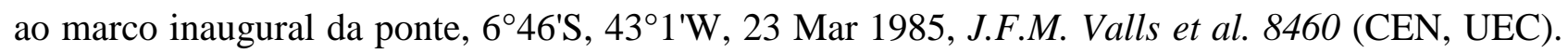
Minas Gerais: Diamantina, estrada para São João da Chapada, 29 Jan 1986, H.M. Longhi-Wagner et al. 9462 (SPF). Pará: Abaetetuba, Estrada Abaetetuba-Igarapemirim, km 23, 152'S, 4852'59"W, s.d., R.F.A. Veiga 153 (CEN). Piauí: Jerumenha, A.S. Silva \& D.B. Crisci 270 (UB). Rio Grande do Norte: Serra Negra do Norte, Estação Ecológica do Seridó, 642'23"S, 37²6'20"W, 21 Abr 2007, R.C. Oliveira et al. 1911 (HEPH, IPA, MOSS, UB, UFRN). Tocantins: Lagoa da Confusão, Ilha do 
Bananal, Parque Nacional do Araguaia, 10²9'25"S, 50²8'40"W, 23 Mar 1999, R.C. Mendonça et al. 3965 (IBGE, ICN); Arraias, estrada Arraias-Natividade, $29 \mathrm{~km}$ de Arraias, 05 Abr 2013, R.C. Oliveira et al. 1911 (UB, HUEFS). GUIANA. Rupunini, Shea, 250'N, 5905'W, 26 Ago 1995, M.J. Jansen-Jacobs et al. 4859 (K, P, U).

4. Mesosetum ansatum (Trin.) Kuhlm, Commissão de Linhas Telegraphicas, Botanica 67(11): 4243, 90. 1922. Fig. $2 d$

Tipo:-Panicum ansatum Trin., Species Graminum 3: t. 279. 1831. Brasil, Mato Grosso, Cuiabá, Jan 1827, s.c., s.n. (holótipo LE-TRIN-0570.01[foto!]; isótipo MO-2100915, US-80459[foto!]).

Sinônimos:-Panicum ansatum var. linearifolium S. Moore, Transactions of the Linnean Society of London, Botany 4 (2): 505. 1895. Brasil, Mato Grosso, entre Santa Cruz e Vila Maria, Dec 18911892, le M. Moore 851 a (holótipo BM!; isótipo: K!, NY-22823 [foto!], US-80460 [foto!]). Thrasya ansata (Trin.) Pilg., Die natürlichen Pflanzenfamilien 14 (2): 69. 1940. Baseado em Panicum ansatum Trin.

Plantas perenes; cespitosas; rizomas ausentes; estolhos presentes, emitidos horizontalmente. Folhas a maioria basais, dispostas na base do colmo. Lâminas foliares planas; membranáceas; linear-lanceoladas; glabras a pilosas, ciliadas, tricomas com base tuberculada. Inflorescências terminais; ráquis encerrando em espigueta desenvolvida, aladas, 2,2-5,2 $\mathrm{mm}$ larg. Espiguetas solitárias dispostas em inflorescências racemiformes; 2,4-4,0 × 0,8-1,4 mm; inseridas em pedicelos com ápice truncado, ca $1 \mathrm{~mm}$ de compr.; lateralmente comprimidas; pilosas, tricomas alvos. Glumas inferiores 2,4-4,0 × 0,8-1,4 mm; 3-nervadas, nervuras encontrando-se na região distal; assimétricas; pilosas, tricomas distribuídos apenas no terço proximal; ápice agudo; múticas. Glumas superiores 2,5-3,6 ×0,4-1,1 mm; 5-nervadas, nervuras não encontrando-se na região distal; pilosas, tricomas distribuídos apenas nas margens; múticas. Antécios inferiores masculinos. Lemas inferiores com tricomas de base não tuberculada, distribuídos ao longo das nervuras 
laterais; nervuras não encontrando-se na região distal. Páleas inferiores presentes. Antécios superiores 1,5 × 1,0 mm; cartáceo; ápice acuminado; anteras alvas a amarelas.

Mesosetum ansatum era conhecido apenas para o estado de Mato Grosso, Brasil. Análise de coletas recentes revelou a ocorrência desta espécie na Bolívia (Silva et al. 2016, Capítulo 5). Até o momento, as populações de $M$. ansatum podem ser saxícolas e foram encontradas em campos úmidos e em margem de rio na região do Pantanal.

A espécie é reconhecida por apresentar ráquis amplamente alada, frequentemente encobrindo as espiguetas e espiguetas com compressão lateral. Por apresentar ráquis alada e espiguetas lateralmente comprimidas, aproxima-se morfologicamente de M. alatum, M. bifarium, M. compressum, M. chaseae, M. elytrochaetum e M. longiaristatum. Mesosetum ansatum distinguese destas por ser a única espécie com ráquis alada que apresenta estames alvos a amarelos e glumas múticas. Mesosetum alatum, M. bifarium, M. compressum, M. chaseae, M. elytrochaetum e M. longiaristatum possuem estames purpúreos e pelo menos uma das glumas aristadas.

Filogeneticamente, M. ansatum é grupo irmão do clado formado por M. annuum, $M$. arenarium, M. chlorostachyum, M. comatum e M. loliiforme (Capítulo 1). A proximidade entre estas espécies também foi demonstrada na análise de agrupamento baseada na ornamentação do antécio superior visualizada em Microscópio Eletrônico de Varredura (Silva et al. 2015, Capítulo 4). Além disso, essas espécies compartilham algumas características morfológicas, tais como, a gluma superior plana e triangulada. Este último carater foi utilizado por Filgueiras (1989) como uma característica diagnose de $M$. sect. Loliiformia.

É registrado o número cromossômico 2n = 8 para M. ansatum (Ribeiro 2016).

Material selecionado: BOLÍVIA. Santa Cruz: 3 km de Las Petas, 16²4'23"S, 59¹0'32"W, 18 mar 2009, J.R.I. Wood \& D. Soto 25392 (UB, USZ). BRASIL. Mato Grosso: Poconé, 20 km da cidade na margem da estrada Porto Cercado, $16^{\circ} 21^{\prime} 4,5^{\prime \prime} \mathrm{S}, 56^{\circ} 29^{\prime} 4,7^{\prime \prime W}, 25$ Mai 2012, R.C. Oliveira et al. 
2766 (UB); Chapada dos Guimarães, Cachoeira do Remo, próximo a curso d'agua, 15²7'38"S, 5544'58"W, 15 Nov 2012, R.C. Oliveira et al. 2766 (UB).

5. Mesosetum arenarium Swallen, Brittonia 2(4): 380-381. 1937. Fig. 1e, 4a

Tipo:-Brasil, Minas Gerais, Serra Santo Antonio, 27-30 Dez 1929, Chase 10403 (holótipo US1500602[foto!]; isótipo B!, K!, MG, MO-5191407[foto!], NY381366 [foto!], RB 35934[foto!], $\mathrm{S}[$ foto!], US[foto!]).

Sinônimos:-Mesosetum aequiglume Swallen, Brittonia 2(4): 381. 1937. Brasil, Minas Gerais, 5$10 \mathrm{~km}$ W de Diamantina, Serra de Santo Antonio, 27-30 Dec 1929, A. Chase 10440 (US1504866[foto!]; isótipo MO-245064[foto!], NY-381362[foto!])

Plantas perenes; cespitosas; rizomas presentes; estolhos ausentes. Folhas caulinares, dispostas ao longo do colmo. Lâminas foliares planas; membranáceas; lanceoladas; glabras a pilosas, ciliadas, tricomas sem base tuberculada. Inflorescências terminais; ráquis encerrando em espigueta desenvolvida, não aladas, ca 1,0 $\mathrm{mm}$ larg. Espiguetas solitárias dispostas em inflorescências racemiformes; 4,4-6,2 × 1,0 mm; inseridas em pedicelos com ápice truncado, ca 1 mm de compr.; dorsiventralmente comprimidas; pilosas, tricomas alvos. Glumas inferiores 4,0-5,0 $\times$ 0,6-1,0 mm; 3-nervadas, nervuras encontrando-se na região distal; simétricas; pilosas, tricomas distribuídos apenas no terço proximal; ápice crestado (nervura central com uma expansão prolongada no dorso, Fig. 1e); múticas. Glumas superiores 4,0-4,5 × 0,6 mm; 3-5-nervadas, nervuras encontrando-se na região distal; pilosas, tricomas distribuídos apenas nas margens; múticas. Antécios inferiores neutros. Lemas inferiores com tricomas de base não tuberculada, distribuídos ao longo das nervuras laterais; nervuras não encontrando-se na região distal. Páleas inferiores ausentes. Antécios superiores 4,2-5,2 × 1,0 mm; cartáceo; ápice acuminado; anteras vináceas. 
Como já comentado sob $M$. annuum, as relações filogenéticas entre $M$. arenarium, $M$. annuum, $M$. chlorostachyum, $M$. comatum e $M$. loliiforme não estão resolvidas em definitivo necessitando mais estudos que analisem diferentes populações dessas espécies do ponto de vista genético, reprodutivo e citológico.

Mesosetum arenarium é morfologicamente mais relacionado à $M$. loliiforme, da qual distingue-se pelo tamanho relativo das glumas e pelas características da gluma inferior. Em $M$. arenarium, as glumas são de tamanho subiguais, a gluma inferior é simétrica com ápice crestado (nervura central com uma expansão prolongada no dorso, Fig. 1e). Já em M. loliiforme, a gluma inferior é conspicuamente menor que a gluma superior, assimétrica e sem ápice crestado.

Não há registros de contagens cromossômicas para M. arenarium.

Material selecionado: BRASIL. Goiás: Cristalina, Serra dos Cristais, ca. $3 \mathrm{~km} \mathrm{~N}$. of Cristalina, 16² $43^{\prime 22}$ "S, 47³6'W, 3 mar 1966, H. S. Irwin 13337 (UB, MO, NY). Minas Gerais, Diamantina Serra de Santo Antônio, 18¹4'57"S, 43³6'1"W, 19 Jan 1984, T.S. Filgueiras \& A.G. Burman 1098 (UB).

6. Mesosetum arnacites (Trin.) A.S. Silva \& R.C. Oliveira, comb. nov. baseado em Panicum arnacites Trin., Species Graminum 3(27): t. 317. 1829-1830. [三Tatianyx arnacites (Trin.) Zuloaga \& Soderstr. Smithsonian Contributions to Botany 59: 56. 1985]. Fig 4f

Tipo:-Brasil, Serra da Lapa, Nov 1824, Langsdorff s.n. (holótipo LE-TRIN-0586.02; isótipo LETRIN-0586.01, US-974682 [foto!]).

Plantas perenes; cespitosas; rizomas presentes; estolhos ausentes. Folhas a maioria basais, dispostas na base do colmo. Lâminas foliares planas a convolutas; membranáceas; linearlanceoladas; glabras a pilosas, esparçamente ciliadas, tricomas sem base tuberculada. Inflorescências terminais; ráquis encerrando em espigueta desenvolvida, não aladas, ca. 0,4 mm 
larg. Espiguetas solitárias dispostas em inflorescências paniculiformes; 4,0-4,5 × 1,0-1,4 mm; inseridas em pedicelos com ápice oblíquo, 1-20 mm de compr.; dorsiventralmente comprimidas; pilosas, tricomas alvos. Glumas inferiores 2,2-3,0 $\times 0,6 \mathrm{~mm}$; 3-5-nervadas, nervuras encontrandose na região distal; simétricas; pilosas, tricomas distribuídos apenas no terço proximal; ápice agudo; múticas. Glumas superiores 2,8-3,5 × 0,6 mm; 5-7-nervadas, nervuras encontrando-se na região distal; pilosas, tricomas uniformemente distribuídos na superfície dorsal; múticas. Antécios inferiores masculinos ou neutros. Lemas inferiores com 2 tufos de tricomas de base não tuberculada no terço distal; nervuras encontrando-se na região distal. Páleas inferiores presentes. Antécios superiores 2,9-3,7 × 1,0 mm; coriáceo; ápice agudo; anteras vináceas.

A hipótese filogenética apresentada para o gênero Mesosetum incluiu o gênero monoespecífico Tatianyx dentro de Mesosetum (Figuras 1, 2, 3, 4, 5, 6, Capítulo 1) com com 100\% de bootstrap nas análises de Máxima Parcimônia e 1.0 de Probabilidades Posteriores nas análises de Inferência Bayesiana.

Morfologicamente, T. arnacites compartilha várias características com Mesosetum, tais como a pilosidade das glumas e lema inferior, inserção da espigueta no pedicelo e cariopse com hilo linear. De fato, Tatianyx apresenta todas as características morfológicas que distinguem Mesosetum dos outros gêneros da subtribo Arthropogoninae.

Mesosetum arnacites era conhecida apenas para os estados da Bahia, Goiás, Minas Gerais, Mato Grosso e Pará. A sua área de ocorrência foi ampliada para o estado de Mato Grosso do Sul. Em todos os registros, a espécie é encontradas em altitudes acima de $800 \mathrm{~m}$ e habita solos arenosos e rochosos.

É registrado o número cromossômico 2n = 60 para M. arnacites (Ribeiro 2016).

Material selecionado: BRASIL. Bahia: Rio de Contas, estrada para Jussiape, ca. $1 \mathrm{~km}$ de Rio de

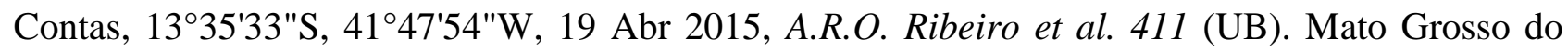


Sul: Costa Rica, Parque Estadual Nascentes do Rio Taquari, entrando pelo algodoal chegando no topo do Canyon, $18^{\circ} 14^{\prime} 3^{\prime \prime S}, 53^{\circ} 18^{\prime} 24^{\prime W}, 26$ Jun 2015, J.E.Q. Faria et al. 4652 (UB).

7. Mesosetum bifarium (Hack.) Chase, Proceedings of the Biological Society of Washington 24: 123. 1911. Fig $1 b, 3 b$

Tipo:-Panicum bifarium Hack. Oesterreichische Botanische Zeitschrift 47: 76. 1897. Brasil, Goiás, Sur le Plateau Central, 5 Jan 1895, Glaziou 22455 (holótipo W!; isótipo B!, BAA, G [foto!], K!, P!, US-80529[foto!], US-1445722[foto!]).

Sinônimos:-Panicum caudiculatum Hack., Oesterreichische Botanische Zeitschrift 47: 76. 1897. Brasil, Goiás, Itiquira ad Fazenda do Cipo, 3 Feb 1895, Glaziou 22453 (W[foto!]; isótipos B!, P00633992!, US-80516[foto!]). Mesosetum caudiculatum (Hack.) Swallen, Brittonia 2(4): 369370. 1937. Baseado em Panicum caudiculatum Hack. Bifaria bifaria (Hack.) Kuntze, Revisio Generum Plantarum 3(3): 359. 1898. Baseado em Panicum bifarium Hack. Bifaria caudiculata (Hack.) Kuntze, Revisio Generum Plantarum 3(3): 359. 1898. Baseado em Panicum caudiculatum Hack.

Plantas perenes; cespitosas; rizomas ausentes; estolhos presentes, emitidos horizontalmente. Folhas caulinares, dispostas ao longo do colmo. Lâminas foliares planas a convolutas; membranáceas; linear-lanceoladas; glabras a pilosas, ciliadas, tricomas sem base tuberculada. Inflorescências terminais; ráquis encerrando em espigueta desenvolvida, aladas, 1,6-2,0 mm larg. Espiguetas solitárias dispostas em inflorescências racemiformes; 3,5-5,7 × 1,0-2,2 mm; inseridas em pedicelos com ápice truncado, ca $1 \mathrm{~mm}$ de compr.; lateralmente comprimidas; pilosas, tricomas alvos. Glumas inferiores 3,5-5,7 × 1,0-2,2 mm; 3-nervadas, nervuras encontrando-se na região distal; simétricas; glabras; ápice bilobado; aristadas, aristas 2-7 mm compr. Glumas superiores 3,2-5,2 × 1,2-1,8 mm; 5-nervadas, nervuras encontrando-se na região distal; pilosas, tricomas distribuídos apenas nas margens no terço proximal; múticas ou mucronadas, múcron até 0,3 mm 
compr. Antécios inferiores masculinos. Lemas inferiores com 2 tufos de tricomas de base não tuberculada no terço distal; nervuras encontrando-se na região distal. Páleas inferiores presentes. Antécios superiores 3,8-4,0 × 1,0 mm; cartáceos; ápice acuminado; anteras vináceas.

Morfologicamente, M. bifarium pode ser confundida com M. alatum e M. elytrochaetum. O melhor caracter para a distinção de $M$. bifarium e $M$. alatum é a inserção da espigueta no pedicelo, discutida sob M. alatum. Além disso, a análise em Microscopia Eletrônica de Varredura do antécio superior auxiliou na busca por caracteres distintivos (Silva et al. 2015, Capítulo 4). Por outro lado, a distinção entre $M$. bifarium e $M$. elytrochaetum é um pouco dificultada, pois em algumas exsicatas foram observados indivíduos com morfologia intermediária entre essas duas espécies, indicando que possivelmente ocorra a formação de híbridos quando $M$. bifarium e $M$. elytrochaetum ocorrem em simpatria. No entanto, é necessário um estudo que envolva análises reprodutivas para a confirmação desta hipótese. Por enquanto, a consistência coriácea e espessa da lâmina foliar e da ráquis em $M$. elytrochaetum junto com as lâminas filiformes típicas desta espécie podem ser utilizadas para distinguir $M$. elytrochaetum de $M$. bifarium, que apresenta as lâminas foliares e a ráquis herbáceas e tenras. As características acima citadas também foram observadas por Ribeiro (2013).

Há dois citótipos conhecidos para M. bifarium, o citótipo diploide com 2n = 8 cromossomos ( $V$ 15927, V 15933) e o citótipo tetraploide $2 \mathrm{n}=16$ cromossomos (A.S.Silva 235, AROR 391). Os dois citótipos diferenciam-se pela forma de crescimento vegetativo (Ribeiro 2016). O citótipo tetraploide possui hábito de crescimento estolonífero, com os nós basais bastante ramificados, produzindo perfilhos o ano inteiro. Em contrapartida, o citótipo diploide possui hábito de crescimento ereto e raramente se ramifica. Quando isto ocorre, os ramos são emitidos nos nós superiores, nunca nos ramos basais.

Filogeneticamente, M. bifarium mostrou-se parafilética (Capítulo 1). No entanto, não existe descontinuidade morfológica que permita a separação fenética entre as duas linhagens de $M$. 
bifarium, o que dificulta a aplicação do Conceito Filogenético de Espécie. Para que os acessos amostrados neste trabalho sejam considerados espécies distintas, é necessário um estudo populacional que envolva uma maior amostragem de indivíduos de $M$. bifarium, como também populações de M. alatum, M. compressum, M. elytrochaetum e M. longiaristatum. É bastante provável que ocorram híbridos naturais entre estas entidades, visto que foram observados indivíduos de morfologia intermediária em populações destas espécies, bem como distribuição geográfica simpátrica. A complexidade da circunscrição das espécies acima citadas também foi relatada por Filgueiras $(1986,1989)$ e Ribeiro (2013).

Material selecionado: BRASIL. Goiás: Teresina de Goiás, Poço Encantado, trilha secundária,

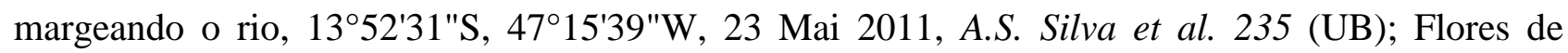
Goiás, 23 Jan 2014, J.F.M. Valls et al. 15933 (CEN); J.F.M. Valls et al. 15927 (CEN).

8. Mesosetum blakei Swallen, Brittonia 2(4): 390-391. 1937. Fig. 3g

Tipo:-Guatemala, Izabal, Cristina, 23 Mai 1919, S.F. Blake 7657 (US-1012994[foto!]).

Sinônimos:-Mesosetum tabascoense Beetle, Phytologia 35(3): 222. 1977. México, Tabasco, Huimanguilla, Rancho Estrella Blanca, 21 Apr 1971, R. Almeida 10.80 (herbário não designado, não visto).

Plantas perenes; cespitosas; rizomas presentes; estolhos ausentes. Folhas a maioria basais, dispostas na base do colmo. Lâminas foliares planas; membranáceas; linear-lanceoladas; glabras a pilosas, ciliadas, tricomas sem base tuberculada. Inflorescências terminais; ráquis encerrando em espigueta desenvolvida, não aladas, 0,3 mm larg. Espiguetas solitárias dispostas em inflorescências racemiformes; $3,0-5,7 \times 0,6-1,1 \mathrm{~mm}$; inseridas em pedicelos com ápice truncado, ca $1 \mathrm{~mm}$ de compr.; dorsiventralmente comprimidas; pilosas, tricomas alvos. Glumas inferiores 3,0-4,8 $\times$ 0,6-1,0 mm; 3-nervadas, nervuras não encontrando-se na região distal; simétricas; pilosas, tricomas 
distribuídos ao longo das nervuras na região proximal; ápice agudo; múticas. Glumas superiores 4,0-5,2 × 0,8-1,0 mm; 5-7-nervadas, nervuras não encontrando-se na região distal; pilosas, tricomas distribuídos apenas nas margens; múticas. Antécios inferiores neutros. Lemas inferiores com tricomas de base não tuberculada, distribuídos ao longo das nervuras laterais; nervuras não encontrando-se na região distal. Páleas inferiores presentes ou ausentes. Antécios superiores 3,0-4,0 × 0,8 mm; cartáceos; ápice acuminado; anteras vináceas.

Mesosetum blakei era conhecida apenas para as Américas Central e do Norte, com registro de ocorrência no México, Belize, Guatemala, Honduras e Nicarágua. É documentada, neste trabalho, pela primeira vez, a ocorrência desta espécie na América do Sul, registrada na Venezuela.

De acordo com a hipótese filogenética apresentada no Capítulo 1, M. blakei é relacionada à M. filifolium e M. wrightii. Além disso, são espécies morfologicamente semelhantes e todas ocorrem em simpatria. Difere de M. filifolium principalmente por apresentar lâminas foliares planas, enquanto que em M. filifolium as lâminas foliares são filiformes. Mesosetum blakei é diferente de M. wrightii por não produzir estolhos e pela presença de tricomas conspícuos nas glumas, enquanto que $M$. wrightii é uma planta essencialmente estolonífera com espiguetas glabrescentes.

Não há registros de contagens cromossômicas para M. blakei.

Material selecionado: HONDURAS. Stann Creek: highway to Mullins River, 14 Abr 1963, R.M.C. Williams 21 (BM). MÉXICO. Tabasco: Villa Hermosa-Escárcega, 10 Mai 1982, G. Davidse et al. 20316 (K, MEXU). NICARÁGUA. Zelaya: ca. 4,2 km NW of Alamikamba, 13³31'N, 84¹5'W, 24 Abr 1978, W.D. Stevens et al. 8188-a (K). VENEZUELA. Departamento Atabapo: area between the western base of Cerro Yapacana and headwaters of Caño Cotuá, 3³8'N, 66 $52^{\prime} \mathrm{W}, 6$ Mai 1959, G. Davidse et al. 17217 (MBM). 

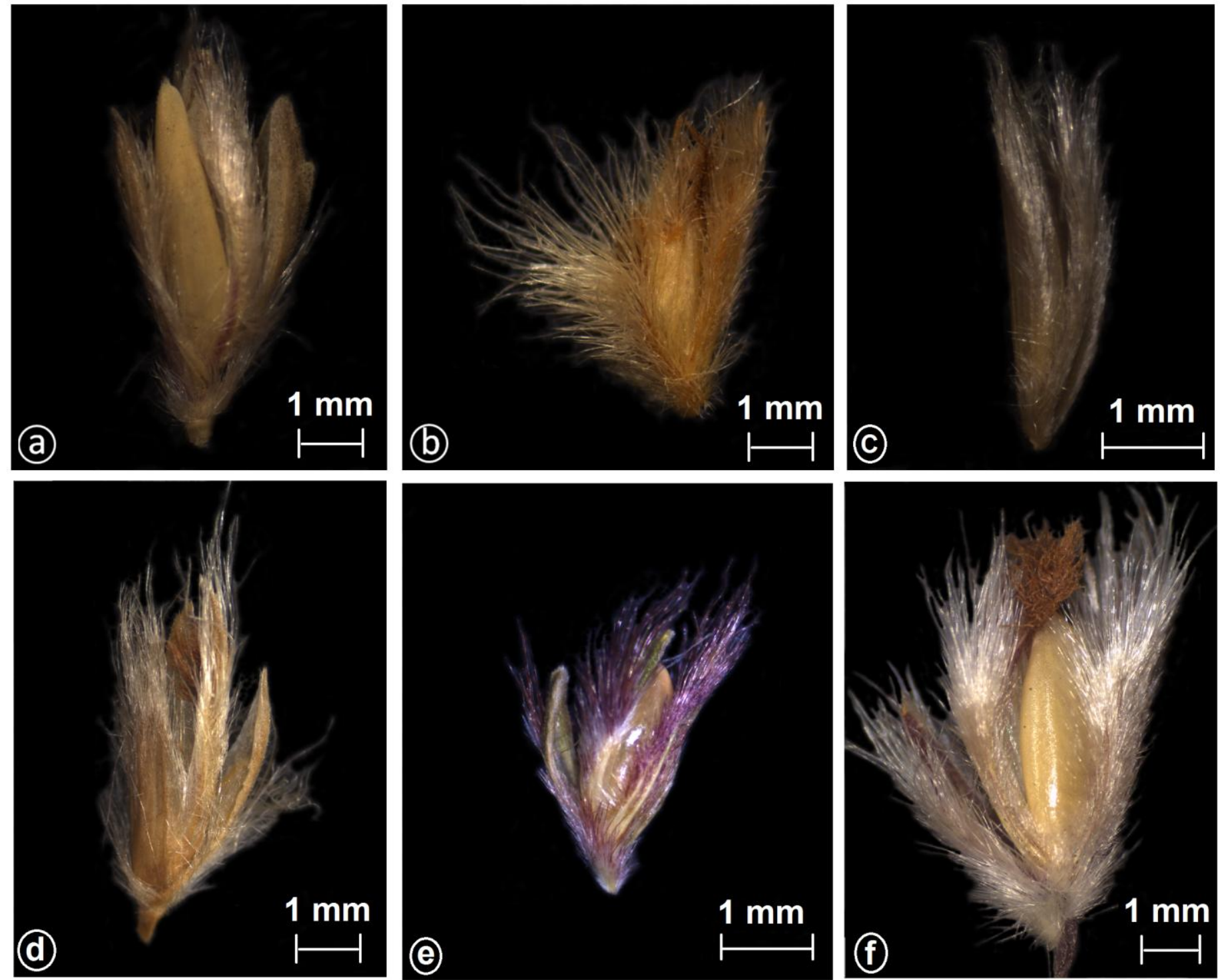

Figura 4. Fotos de espécies de Mesosetum: (a) espigueta de M. arenarium Swallen, Burman 468 (SP); (b) espigueta de M. exaratum (Trin.) Chase, T. Sendulsky 443 (UB); (c) espigueta de M. filifolium F.T. Hubb., P.L. Viana et al. 3438 (IAN); (d) espigueta de M. gibbosum Swallen, Harley 50773 (HUEFS); (e) espigueta de M. pappophorum (Nees) Kuhlm., J.F.M. Valls et al. 15949 (CEN); (f) espigueta de M. arnacites (Trin.) A.S. Silva \& R.C. Oliveira, Hatchsbach 52312 (HUEFS). 
9. Mesosetum cayennense Steud., Synopsis Plantarum Glumacearum 1: 118. 1854. Fig 5a

Tipo:-Guiana Francesa, Cayenne, 1825, Leprieur s.n. (holótipo P!; isótipo: L [foto!]).

Plantas perenes; cespitosas; rizomas presentes; estolhos ausentes. Folhas caulinares, dispostas ao longo do colmo. Lâminas foliares planas; membranáceas; lanceoladas; glabras a pilosas, ciliadas, tricomas sem base tuberculada. Inflorescências terminais; ráquis encerrando em espigueta desenvolvida, não aladas, 0,3 mm larg. Espiguetas solitárias dispostas em inflorescências racemiformes; 3,8-4,7 ×0,6-1,1 mm; inseridas em pedicelos com ápice oblíquo, ca $1 \mathrm{~mm}$ de compr.; dorsiventralmente comprimidas; pilosas, tricomas ferrugíneos, raro amarelo-pálidos. Glumas inferiores 2,8-3,1 $\times$ 0,6-1,0 mm; 3-nervadas, nervuras não encontrando-se na região distal; simétricas; pilosas, com dois tufos de tricomas na região mediana; ápice truncado ou eroso; múticas. Glumas superiores 3,5-4,0 × 0,8-1,0 mm; 3-5-nervadas, nervuras não encontrando-se na região distal; pilosas, com 2 tufos de tricomas no dorso na região distal; múticas. Antécios inferiores neutros. Lemas inferiores com tricomas de base não tuberculada, distribuídos ao longo das nervuras laterais; nervuras não encontrando-se na região distal. Páleas inferiores ausentes. Antécios superiores 3,0-3,2 × 0,8 mm; cartáceos; ápice agudo; anteras vináceas.

Mesosetum cayennense é uma espécie polimórfica e amplamente distribuída na América do Sul. Relaciona-se com M. rottboellioides, M. ferrugineum e Mesosetum sp. nov. 1, formando um clado bem suportado (Capítulo 1). Estas espécies compartilham muitas características exclusivas, tais como, o número cromossômico básico x = 10 (Sousa 2014, Ribeiro 2016), tricomas ferrugíneos nas espiguetas e espiguetas inseridas em pedicelos oblíquos. Além disso, a superfície do antécio superior é inteiramente coberta por papilas compostas de formato exclusivo, diferente de todas as demais espécies do gênero (Silva et al. 2015, Capítulo 4).

Morfologicamente é mais próxima de M. rottboellioides, sob a qual já foi sinonimizada (Hitchcock 1909). Em geral, M. cayennense pode ser distinguida pela distribuição das folhas no 
colmo caulinar, gluma inferior com ápice truncado ou retuso, com dois tufos de tricomas na região mediana e gluma superior com dois tufos de tricomas no dorso na região distal (Fig. 5a). Em contrapartida, em $M$. rottboellioides as folhas concentram-se na região basal do colmo, a gluma inferior tem ápice arredondado, agudo ou acuminado, os tricomas da gluma inferior são distribuídos uniformemente ao longo das margens, a gluma superior sem tufos de tricomas, com tricomas distribuídos uniformemente na superfície dorsal (Fig. 5b).

Material selecionado: BOLÍVIA. Santa Cruz: Chiquitos, na estrada entre Santiago de Chiquitos e Roboré, após a propriedade Sanjuanama, 18²0'14"S, 59³9'42"W, R.C. Oliveira et al. 2974 (UB). BRASIL. Goiás: Flores de Goiás, à $12 \mathrm{~km}$ do trevo de flores, lado direito da BR., $14^{\circ} 53^{\prime} 49^{\prime \prime}$, 46 57'3"W, P.A. Reis et al. 181 (UB); J.F.M. Valls et al. 15922 (CEN); J.F.M. Valls et al. 15934

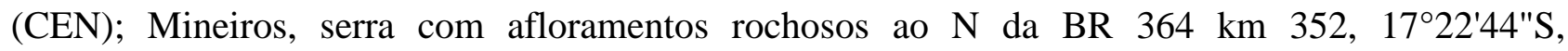
52 55'26"W, G.H. Rua et al. 940 (UB); Alto Paraíso de Goiás, 14'47"S, 47¹6'53"W, R.C. Oliveira et al. 2744 (UB). Tocantins: Lagoa da Confusão, Ilha do Bananal, Parque Nacional do Araguaia, 10²9'25"S, 50²8'40"W, 23 Mar 1999, R.C. Mendonça et al. 3975 (IBGE); Natividade,

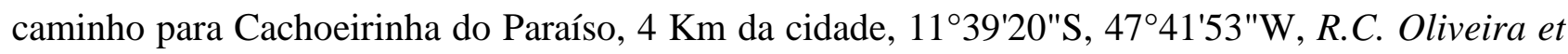
al. 2848 (UB, HUEFS).
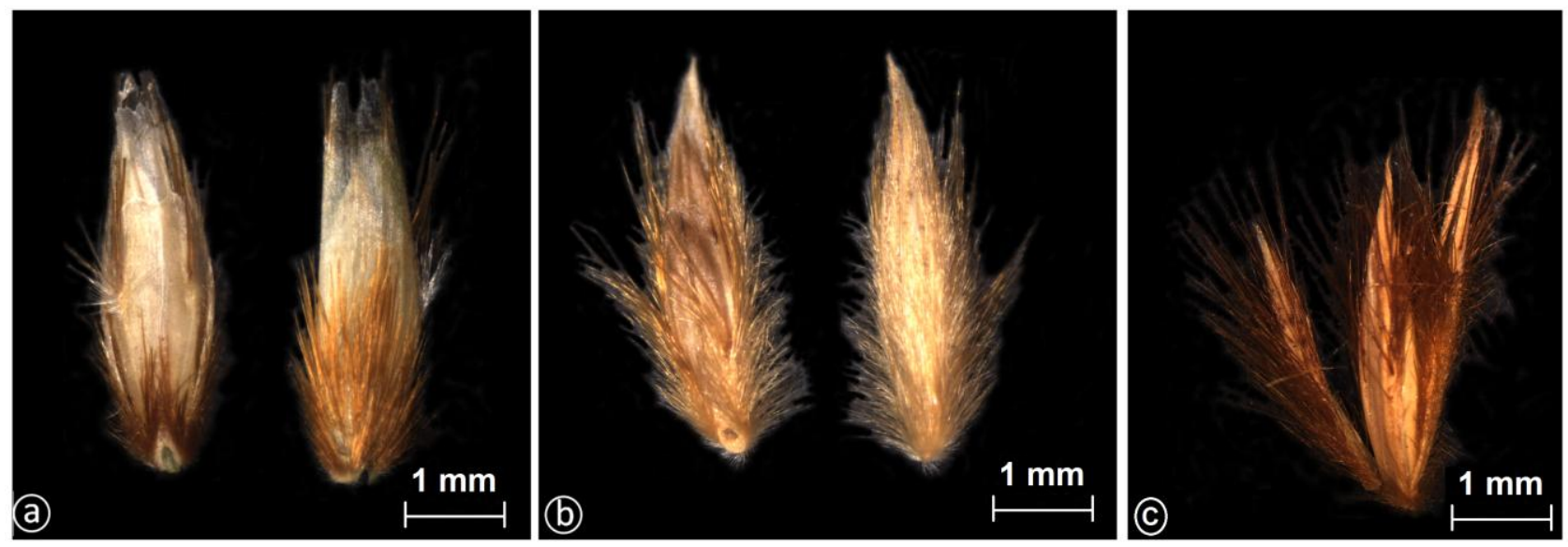

Figura 5. Fotos de espécies de Mesosetum: (a) espigueta de M. cayennense Steud., vista ventral, vista dorsal, P.A. Reis et al. 181 (UB); (b) espigueta de M. rottboellioides (Kunth) Hitchc., vista ventral, vista dorsal, P.A. Reis et al. 331 (UB); (c) espigueta de M. ferrugineum (Trin.) Chase, R.C. Oliveira. et al. $2970(U B)$. 
10. Mesosetum chaseae Luces, Journal of the Washington Academy of Sciences 32(6): 160, f. 5. 1942. Fig. 3c

Tipo:- Venezuela, Anzoátegui, vicinity of Santomé, Ago-Nov 1940, A.G. Sandoval s.n. (holótipo VEN; isótipo US-1764957[foto!])

Sinônimos:-Mesosetum cardonum Luces, Boletín de la Sociedad Venezolana de Ciencias Naturales 15(80): 19-20, f. 12. 1953. Venezuela, Bolívar, Gran Sabana, entre Cerros Acopán y Upuima, 900 m, Oct 1947, F. Cardona 2223a (holótipo VEN; isótipo US-2947515[foto!]). Mesosetum stoloniferum Swallen, Contributions from the United States National Herbarium 29(9): 412. 1950. Guatemala, Chiquimula, $3 \mathrm{mi}$ SE of Quezaltenango, vicinity of Montaña Cebollas, along Río Lucia Saso, on dry rocky slopes of open glade, 1200-1500 m, 6 Nov 1939, Steyermark 31266 (holótipo F-1061061; isótipo US-2152610[foto!]).

Plantas perenes; cespitosas; rizomas presentes; estolhos presentes, emitidos horizontalmente. Folhas caulinares, dispostas ao longo do colmo. Lâminas foliares planas; membranáceas; lanceoladas; glabras a pilosas, ciliadas, tricomas sem base tuberculada. Inflorescências terminais; ráquis encerrando em espigueta desenvolvida, aladas, $0,7-1,1 \mathrm{~mm}$ larg. Espiguetas solitárias dispostas em inflorescências racemiformes; 3,2-5,5 × 0,7-1,4 mm; inseridas em pedicelos com ápice truncado, ca $1 \mathrm{~mm}$ de compr.; lateralmente comprimidas; pilosas, tricomas alvos. Glumas inferiores 3,2-4,7 × 0,7-1,4 mm; 3-nervadas, nervuras encontrando-se na região distal; simétricas; glabras, margens escabras; ápice agudo; mucronadas ou aristadas, aristas $0,2-1,0$ mm de compr. Glumas superiores 2,9-4,6 × 0,7-1,1 mm; 5-nervadas, nervuras encontrando-se na região distal; pilosas, com tricomas ao longo das nervuras laterais; múticas ou mucronadas, 0,2 mm. Antécios inferiores masculinos ou neutros. Lemas inferiores com tricomas de base não tuberculada, distribuídos ao longo das nervuras laterais; nervuras encontrando-se na região distal. Páleas inferiores presentes. Antécios superiores 3,0-4,5 × 0,8 mm; cartáceos; ápice agudo; anteras vináceas. 
Mesosetum chaseae apresenta ampla distribuição geográfica, com registros no Brasil, Guiana, Guatemala, Honduras, Paraguai, Trindade e Tobago e Venezuela (Filgueiras 1989). Recentemente encontramos esta espécie na Bolívia (Silva et al. 2016, Capítulo 5).

Filgueiras (1989) citou a ocorrência desta espécie no Brasil, para os estados do Mato Grosso do Sul, Minas Gerais e Roraima. Durante a realização deste trabalho, foi confirmada a ocorrência de M. chaseae também para os estados de Mato Grosso e Bahia (Silva et al. 2016, Capítulo 5).

São conhecidos dois citótipos para $M$. chaseae, o tetraploide com 2n = 16 cromossomos, que é amplamente estudado como uma alternativa forrageira autóctone para a região do Pantanal Sul Matogrossense (Silva et al. 2012, Meireles et al. 2015). O hexaploide 2n $=24$ cromossomos, foi estudado por Ribeiro (2013, 2016), que encontrou semelhanças entre os cromossomos desta espécie e M. compressum, M. alatum, M. bifarium e M. longiaristatum, o que corrobora a filogenia apresentada no Capítulo 1, na qual estas espécies formam um clado fortemente suportado. Ver comentários sobre a delimitação morfológica dessas espécies sob M. alatum.

Material selecionado: BOLÍVIA. Santa Cruz: Roboré, 18²18'38"S, 5947'6.6"W, 13 Dez 2014, R.C. Oliveira et al. 2981 (UB). BRASIL. Bahia: Lençóis, Serra da Chapadinha, 1247'44"S, 41²6'23"W, 24 Fev 1995, E. Melo et al. 1733 (K); Mato Grosso: Poconé, 16²0’10”S, 56¹8’06”W, 25 Mai 2012, R.C. Oliveira et al. 2772 (UB).

11. Mesosetum chlorostachyum (Döll) Chase, Proceedings of the Biological Society of Washington 24: 122. 1911.

Tipo:-Panicum chlorostachyum Döll, Flora Brasiliensis 2(2): 173, t. 28a. 1877. Brasil, Amazonas, in regionibus fluminis Rio Negro, Dec 1850- Mar 1851, R. Spruce 885 (lectótipo M; isolectótipo US-80567 [foto!]). Lectótipo designado por Filgueiras, Acta Amaz. 19: 77 (1989). 
Plantas anuais; cespitosas ou decumbentes; rizomas ausentes; estolhos ausentes. Folhas caulinares, dispostas ao longo do colmo. Lâminas foliares planas; membranáceas; linearlanceoladas; glabras a pilosas, ciliadas, tricomas com base tuberculada. Inflorescências terminais; ráquis encerrando em espigueta desenvolvida, não aladas, 1,0-1,2 mm larg. Espiguetas solitárias dispostas em inflorescências racemiformes; 3,0-3,5 × 0,7-1,1 mm; inseridas em pedicelos com ápice truncado, ca $1 \mathrm{~mm}$ de compr.; dorsiventralmente comprimidas; glabras. Glumas inferiores 2,0-3,2 × 0,7-1,0 mm; 3-nervadas, nervuras não encontrando-se na região distal; simétricas; glabras; ápice agudo; múticas. Glumas superiores 2,0-2,8 × 0,7-1,0 mm; 3-nervadas, nervuras não encontrando-se na região distal; glabras; múticas. Antécios inferiores neutros. Lemas inferiores glabros. Páleas inferiores presentes. Antécios superiores $3,0 \times 0,8 \mathrm{~mm}$; cartáceos; ápice acuminado; anteras vináceas.

Mesosetum chlorostachyum é uma espécie anual que vegeta em campos de várzea da Amazônia, com registro de ocorrência nos estados do Amazonas, Mato Grosso e Pará, Brasil. Também ocorre na Venezuela.

Filogeneticamente, M. chlorostachyum é relacionada a $M$. annuum, M. arenarium, $M$. comatum e $M$. loliiforme (Capítulo 1). O clado formado por essas espécies apresenta pouca resolução internamente, necessitando mais estudos para uma compreensão mais acurada das suas relações evolutivas. Morfologicamente, Filgueiras (1989) já tinha relacionado M. chlorostachyum a M. аппиит е M. loliiforme. Ver comentários sobre a delimitação morfológica dessas espécies sob M. аппиит.

É registrado o número cromossômico 2n = 8 para M. chlorostachyum (Ribeiro 2016).

Material selecionado: BRASIL. Amazonas: Manaus, Chácara Nossa Senhora de Fátima, Careiro da Várzea, Cabeceira do São José, afluente do Rio Negro, 28 Abr 2015, R.C. Oliveira et al. 3033 (UB). 
12. Mesosetum comatum Swallen, Journal of the Washington Academy of Sciences 30(5): 215. 1940. Fig. 2g, h

Tipo:-Argentina, Misiones, San Ignacio, Cerro Piedras, 10 Mar 1914, D. Rodríguez 31 (holótipo US-1721241[foto!]; isótipo BAA!)

Plantas perenes; cespitosas; rizomas presentes; estolhos ausentes. Folhas caulinares, dispostas ao longo do colmo. Lâminas foliares planas; membranáceas; lanceoladas; glabras a pilosas, ciliadas, tricomas com ou sem base tuberculada. Inflorescências terminais; ráquis encerrando em espigueta desenvolvida, não aladas, 0,5 mm larg. Espiguetas solitárias dispostas em inflorescências racemiformes; 3,5-4,5 × 0,7-1,2 mm; inseridas em pedicelos com ápice truncado, ca 0,7 mm de compr.; dorsiventralmente comprimidas; pilosas, tricomas alvos. Glumas inferiores 2,8-3,2 × 0,6-1,0 mm; 3-nervadas, nervuras não encontrando-se na região distal; assimétricas; pilosas, tricomas com base tuberculada no terço proximal; ápice obtuso; múticas. Glumas superiores 2,9-3,4 $\times$ 0,7-1,1 mm; 3-nervadas, nervuras não encontrando-se na região distal; pilosas, com tricomas ao longo das nervuras laterais; múticas. Antécios inferiores neutros. Lemas inferiores com tricomas de base tuberculada, distribuídos ao longo das nervuras laterais; nervuras não encontrando-se na região distal. Páleas inferiores ausentes. Antécios superiores 3,2-3,5 × 1,0 mm; cartáceos; ápice agudo; anteras vináceas.

Mesosetum comatum era considerado endêmico da Argentina, com registros para Missiones (http://www.floraargentina.edu.ar/). Esta espécie foi documentada para o Brasil, onde foi encontrada na Chapada Diamantina, Bahia (Silva et al. 2016).

Mesosetum comatum é reconhecido por apresentar espiguetas conspicuamente hirsutas com tricomas de base tuberculada na região proximal da gluma inferior e nas nervuras marginais do 
lema inferior. Pode ser confundido com M. loliiforme (Fig. 2e), o qual se distingue pela pilosidade da espigueta e por não apresentar tricomas de base tuberculada na gluma inferior e lema inferior.

Não há registros de contagens cromossômicas para M. comatum.

Material selecionado: ARGENTINA. Misiones: Dpto. San Ignacio, Teyú Cuaré, 27¹6'40"S, 55³3'36"W, 26 Abr 2011, A.I. Honfi et al. 1542 (UB). BRASIL. Bahia: Piatã, 134'43.2"S, 41ํㄱ'19.7"W, 20 Abr 2015, A.R.O. Ribeiro \& J.E.Q. Faria 418 (UB); Palmeiras, 12²6'8"S, 41³1'4"W, 26 Mar 2011, S.P.S. Neves 417 (HUEFS).

13. Mesosetum compressum Swallen, Brittonia 2(4): 367-369, f. 1. 1937. Fig. 3d

Tipo:-Brasil, inter Pernambuco et Rio, Swainson s.n. (holótipo BM!)

Plantas perenes; cespitosas; rizomas presentes; estolhos presentes, emitidos horizontalmente. Folhas caulinares, dispostas ao longo do colmo. Lâminas foliares planas; membranáceas; lanceoladas; glabras a pilosas, ciliadas, tricomas com base tuberculada. Inflorescências terminais; ráquis encerrando em espigueta desenvolvida, aladas, 1,3-2,1 mm larg. Espiguetas solitárias dispostas em inflorescências racemiformes; 3,7-5,6 × 1,2-2,2 mm; inseridas em pedicelos com ápice truncado, ca 1,0 $\mathrm{mm}$ de compr.; lateralmente comprimidas; pilosas, tricomas alvos. Glumas inferiores 3,7-5,6 × 1,2-2,2 mm; 3-nervadas, nervuras encontrando-se na região distal; simétricas; glabras; ápice bilobado; aristadas, aristas 2,0-12,0 mm compr. Glumas superiores 3,7-5,4 × 1,2-2,0 mm; 5-nervadas, nervuras encontrando-se na região distal; glabras,; múticas, mucronadas ou aristadas, aristas até 1,6 mm compr. Antécios inferiores masculinos. Lemas inferiores com 2 tufos de tricomas sem base tuberculada; nervuras anastomosadas na região distal. Páleas inferiores presentes. Antécios superiores 3,0-3,5 × 1,0 mm; cartáceos; ápice agudo; anteras vináceas. 
Até pouco tempo, M. compressum era conhecida apenas de exsicatas depositadas em herbários. Isto fez com que Filgueiras (1989) classificasse esta espécie como anual. A coleta recente de $M$. compressum (ASS 274) em Pernambuco mostra que se trata de uma espécie com hábito de vida perene, o que corrobora a descrição original (Swallen 1937). Esta população está sendo mantida em cultivo em Casa de Vegetação da UnB, onde produz estolhos e floresce de julho a novembro.

Na hipótese filogenética proposta no Capítulo 1, M. compressum relaciona-se com $M$. alatum, M. chaseae e com os citótipos poliploides de M. bifarium e M. longiaristatum. Filgueiras (1989) e Ribeiro (2013) já tinham relatado a proximidade morfológica entre essas espécies, que podem ser diferenciadas pelos carateres apontados sob M. alatum.

É registrado o número cromossômico 2n = 16 para $M$. compressum (Ribeiro 2016).

Material selecionado: BRASIL. Pernambuco: Pesqueira, Serra do Ororubá, 8²1'28"S, 3641'47"W, 9 Ago 2014, A.S. Silva \& D.B.Crisci 274 (UB).

14. Mesosetum elytrochaetum (Hack.) Swallen, Brittonia 2(4): 370. 1937. Fig. $3 f$

Tipo:-Panicum elytrochaetum Hack. Oesterreichische Botanische Zeitschrift 47: 77. 1897. Brasil, inter flumina Rio dos Couros et Rio Fiçarao, 18 Jan 1895, Glaziou 22454 (holótipo W!; isótipo B!, G [foto!], K!, P!, S[foto!], US-80629 [foto!])

Sinônimos:-Bifaria elytrochaeta (Hack.) Kuntze, Revisio Generum Plantarum 3(3): 359. 1898. Baseado em Panicum elytrochaetum Hack.

Plantas perenes; cespitosas; rizomas presentes; estolhos presentes, vistos apenas em cultivo, emitidos verticalmente. Folhas a maioria basais, dispostas na base do colmo. Lâminas foliares filiformes; coriáceas; setáceas; glabras. Inflorescências terminais; ráquis encerrando em espigueta desenvolvida, aladas, 0,4-1,5 mm larg. Espiguetas solitárias dispostas em inflorescências 
racemiformes; 3,8-5,5 × 0,5-2,0 mm; inseridas em pedicelos com ápice truncado, ca 1,0 mm de compr.; lateralmente comprimidas; pilosas, tricomas alvos. Glumas inferiores $3,8-5,5 \times 0,5-2,0$ mm; 3-nervadas, nervuras encontrando-se na região distal; simétricas; glabras, margens escabras; ápice bilobado; aristadas, aristas 3,0-9,0 mm compr. Glumas superiores 2,8-4,4 × 0,8-2,0 mm; 5nervadas, nervuras encontrando-se na região distal; pilosas, com 1 tufo de tricomas sem base tuberculada; múticas, mucronadas ou aristadas, aristas até 1,0 $\mathrm{mm}$ compr. Antécios inferiores masculinos ou neutros. Lemas inferiores com 2 tufos de tricomas sem base tuberculada; nervuras encontrando-se na região distal. Páleas inferiores presentes. Antécios superiores 3,0-3,2 × 1,0 mm; cartáceos; ápice agudo; anteras vináceas.

Mesosetum elytrochaetum é endêmica da Chapada dos Veadeiros, Goiás. É uma planta de hábito cespitoso e ereto que emite estolhos tardiamente, estes surgem apenas nos nós superiores. Entretanto, esta caraterística somente pode ser observada em material vivo e não foi constatada em exemplares herborizados. A emissão dos estolhos tardios nos nós superiores também foi observada por Ribeiro (2013).

Esta espécie relaciona-se filogeneticamente com os citótipos diploides $2 \mathrm{n}=8$ cromossomos de $M$. bifarium e $M$. longiaristatum. Também está relacionada ao clado formado por $M$. blakei, $M$. filifolium e M. wrightii (Capítulo 1). Todavia, apenas a $M$. bifarium é mais semelhante na morfologia e pode ser distinguida desta pelas características comentadas sob M. bifarium.

É registrado o número cromossômico 2n = 24 para M. elytrochaetum (Ribeiro 2013, 2016).

Material selecionado: BRASIL. Goiás: Alto Paraíso de Goiás, Vila São Jorge, 14¹1'5"S, 4748'42"W, 29 Jan 2012, R.C. Oliveira et al. 2722 (UB). 
15. Mesosetum exaratum (Trin.) Chase, Proceedings of the Biological Society of Washington 24: 121. 1911. Fig. 4b

Tipo:-Panicum exaratum Trin. De Graminibus Paniceis 160. 1826. Brasil, Minas Gerais, Serra do Cipó, (Serra da Lapa), in pratis paludosis, s.d., Langsdorff s.n. (holótipo LE-TRIN0700.01[foto!]; isótipo B!)

Plantas perenes; cespitosas; rizomas presentes; estolhos ausentes. Folhas a maioria basais, dispostas na base do colmo. Lâminas foliares filiformes; cartáceas; setáceas; glabras. Inflorescências terminais; ráquis encerrando em espigueta desenvolvida, não aladas, 0,5 mm larg. Espiguetas solitárias dispostas em inflorescências racemiformes; 3,8-5,2 × 0,5-1,5 mm; inseridas em pedicelos com ápice truncado, ca 1,0 mm de compr.; dorsiventralmente comprimidas; pilosas, tricomas alvos. Glumas inferiores 2,8-3,5 $\times$ 0,5-1,5 $\mathrm{mm} ; 3$-5-nervadas, nervuras não encontrando-se na região distal; simétricas; pilosas, tricomas com base tuberculada distribuídos ao longo das nervuras laterais; ápice bidentado; múticas. Glumas superiores 3,5-4,0 × 0,8-1,5 mm; 5-nervadas, nervuras não encontrando-se na região distal; pilosas, com tricomas com base tuberculada distribuídos ao longo das nervuras; múticas. Antécios inferiores neutros. Lemas inferiores com 2 tufos de tricomas de base tuberculada no terço distal; nervuras não encontrando-se na região distal. Páleas inferiores ausentes. Antécios superiores 3,0-3,5 × 0,6-1,0 mm; membranáceos; ápice agudo; anteras vináceas.

Esta espécie é endêmica do Brasil, com registro de ocorrência nos estados de Minas Gerais, São Paulo e Paraná. Há indícios de que M. exaratum floresce após o fogo, pois em muitas exsicatas examinadas é possível observar a ausência de lâminas foliares e as bainhas foliares carbonizadas.

Mesosetum exaratum é grupo irmão de M. sect. Mesosetum (Capítulo 1). Apesar da proximidade filogenética com este clado, M. exaratum conserva uma história evolutiva singular. 
Até o momento, $M$. exaratum é a única espécie do gênero que apresenta número cromossômico básico $\mathrm{x}=13$ (Ribeiro 2016) e pouco se sabe sobre a sua origem.

Morfologicamente, assemelha-se à M. filifolium. No entanto, pode ser distinguida pelas características das espiguetas. Mesosetum exaratum possui gluma superior com dorso densamente piloso, lema inferior com tufos de tricomas de base tuberculada e antécio cartáceo, enquanto que em M. filifolium, a gluma superior possui tricomas apenas nas margens, lema inferior com tufos de tricomas sem base tuberculada e antécio membranáceo. Caracteres micromorfológicos encontrados no antécio superior suportam ainda mais a distinção destas espécies (Silva et al. 2015, Capítulo 4).

Material selecionado: BRASIL. Minas Gerais: Serra do Cipó, MG 010 em direção Alto Palácio, 19¹7'19"S, 43³5'32"W, 23 Nov 2013, A.R.O. Ribeiro et al 351 (UB). São Paulo: São José do Barreiro, área a esquerda da Guarita do IBAMA, 22³8'24"S, 44³4'12"W, 17 Nov 1999, L. Freitas 753 (CEN, UEC). Paraná: entre Piraí do Sul e Jaguariaíva, próximo ao viaduto Joaquim Murtinho, 3 Fev 1988, J.F.M. Valls et al. 11260 (CEN, IBGE, K, MO).

16. Mesosetum ferrugineum (Trin.) Chase, Proceedings of the Biological Society of Washington 24: 122. 1911. Fig. 5c

Tipo:-Panicum ferrugineum Trin. De Graminibus Paniceis 159. 1826. Brasil, Minas Gerais, perto de Santa Luzia, Out, Langsdorff s.n. (holótipo LE-TRIN-0479.02 [foto!]).

Sinônimos:-Panicum eriochrysoides Nees, Flora Brasiliensis seu Enumeratio Plantarum 2(1): 103-104. 1829. Brasil, Habitat in Brasilia meridionali, s.d., Sellow 1244 (holótipo B!; isótipo US80763[foto!]). Mesosetum eriochrysoides (Nees) Kuhlm., Commissão de Linhas Telegraphicas, Botanica 67(11): 42, 90. 1922. Baseado em Panicum eriochrysoides Nees. Mesosetum tenue Renvoize \& Filg., Kew Bulletin 39(1): 180. 1984. Brasil, Bahia, Rio de Contas, Pico das Almas, 22 Jul 1979, Mori et al. 12473 (holótipo CEPEC!). 
Plantas perenes; cespitosas; rizomas presentes; estolhos ausentes. Folhas caulinares, dispostas ao longo do colmo. Lâminas foliares planas a filiformes; membranáceas; linear a lanceoladas; glabras a pilosas, ciliadas, com ou sem tricomas de base tuberculada. Inflorescências terminais; ráquis encerrando em espigueta desenvolvida, não aladas, 0,5 mm larg. Espiguetas solitárias dispostas em inflorescências racemiformes; 3,1-7,2 × 0,5-2,2 mm; inseridas em pedicelos com ápice oblíquo, ca 1,0 $\mathrm{mm}$ de compr.; dorsiventralmente comprimidas; pilosas, tricomas ferrugíneos. Glumas inferiores 3,8-5,0 × 0,5-1,5 mm; 3-nervadas, nervuras não encontrando-se na região distal; simétricas; pilosas, tricomas sem base tuberculada distribuídos ao longo das nervuras laterais; ápice agudo; múticas. Glumas superiores 3,1-7,2 × 0,5-2,2 mm; 5-7-nervadas, nervuras não encontrando-se na região distal; pilosas, com tricomas sem base tuberculada uniformemente distribuídos no dorso; múticas. Antécios inferiores neutros. Lemas inferiores com tricomas de não base tuberculada distribuídos ao longo das nervuras laterais; nervuras não encontrando-se na região distal. Páleas inferiores ausentes. Antécios superiores 3,8-5,0 × 0,6-1,0 mm; cartáceos; ápice agudo; anteras vináceas.

Espécie endêmica do Brasil, com registro de ocorrência para os estados da Bahia, Distrito Federal, Goiás, Mato Grosso, Minas Gerais, São Paulo e Paraná.

Mesosetum ferrugineum é mais próxima de M. cayennense, M. rottboellioides e Mesosetum sp. nov. 1, tanto na morfologia quanto na análise filogenética proposta no Capítulo 1. Pode ser diferenciada de $M$. cayennense pelo formato da gluma inferior (ápice truncado em $M$. cayennense e ápice agudo em M. ferrugineum) e pela distribuição dos tricomas na gluma superior (dois tufos de tricomas na superfície dorsal em $M$. cayennense e tricomas uniformemente distribuídos em $M$. ferrugineum). E difere de $M$. rottboellioides pela largura da gluma inferior (mesma largura da espigueta em $M$. ferrugineum e mais estreita que a espigueta em $M$. rottboellioides) e tamanho do antécio superior (antécio maior que $4 \mathrm{~mm}$ em $M$. ferrugineum e antécio até 3,5 $\mathrm{mm}$ em $M$. rottboellioides). 
Mesosetum ferrugineum é polimórfico em seus caracteres vegetativos, com populações apresentando lâminas foliares planas e glabras, ou planas e vilosas, ou ainda filiformes e glabras. Filgueiras (1986) sugeriu subdividir esta espécie em três variedades de acordo com o seu aspecto vegetativo. Sousa (2014) e Ribeiro (2016) encontraram dois citótipos para esta espécie. O citótipo diploide $2 \mathrm{n}=20$ cromossomos corresponde à morfologia proposta para $M$. ferrugineum var. setaceum, com lâminas foliares aciculares (AROR 409 - UB). Já o citótipo hexaplóide 2n = 60 cromossomos corresponde à morfologia típica desta espécie com lâminas planas e glabras (MWSS 64 - UB). Portanto, M. ferrugineum var. setaceum pode ser restabelecida.

Material selecionado: BRASIL. Bahia: Rio de Contas, estrada para Jussiape, ca. $1 \mathrm{~km}$ de Rio de Contas, 13³5'33"S, 4147'54"W, 19 Abr 2015, A.R.O. Ribeiro 409 (UB). Distrito Federal: Brasília, Fercal, estrada para o paredão, 27 Nov 2014, R.C. Oliveira \& A.S. Silva 2968 (UB); R.C. Oliveira \& A.S. Silva 2970 (UB). Goiás: Cavalcante, caminho para a Reserva do Tombador, 1347'51"S, 47²7'29"W, 08 Dez 2012, R.C. Oliveira et al. 2786 (UB, UFU).

17. Mesosetum filifolium F.T. Hubb., Proceedings of the American Academy of Arts and Sciences 49(8): 494. 1914[1913]. Fig. 2c, 4c

Tipo:-British Honduras, El Cayo, near Manatee Lagoon, pine ridge, 30 Out 1905, M.E. Peck 136 (holótipo GH)

Sinônimos:-Peniculus angustifolius Swallen, American Journal of Botany 19(7): 581, f. 1. 1932. Belize, El Cayo, Mountain Pine Ridge; 25 Feb 1931, H.H. Bartlett 11748 (holótipo US-1535396). Mesosetum angustifolium (Swallen) Swallen, Journal of the Washington Academy of Sciences 23(10): 460. 1933. Baseado em Peniculus angustifolius Swallen.

Plantas perenes; cespitosas; rizomas presentes; estolhos ausentes. Folhas a maioria basais, dispostas na base do colmo. Lâminas foliares filiformes; membanáceas; setáceas; glabras. 
Inflorescências terminais; ráquis encerrando em espigueta desenvolvida, não aladas, 0,5 mm larg. Espiguetas solitárias dispostas em inflorescências racemiformes; 3,8-5,2 × 0,5-1,2 mm; inseridas em pedicelos com ápice truncado, ca 1,0 mm de compr.; dorsiventralmente comprimidas; pilosas, tricomas alvos. Glumas inferiores 2,8-5,0 × 0,5-1,5 mm; 3-nervadas, nervuras não encontrando-se na região distal; simétricas; pilosas, tricomas sem base tuberculada distribuídos ao longo das nervuras laterais; ápice agudo; múticas. Glumas superiores 4,0-5,4 × 0,8-1,5 mm; 5-7-nervadas, nervuras não encontrando-se na região distal; pilosas, com tricomas sem base tuberculada distribuídos ao longo das nervuras; múticas. Antécios inferiores neutros. Lemas inferiores com 2 tufos de tricomas de base não tuberculada no terço distal; nervuras não encontrando-se na região distal. Páleas inferiores ausentes. Antécios superiores 3,2-4,2 × 0,6-1,0 mm; membranáceos; ápice agudo; anteras vináceas.

A distribuição conhecida de M. filifolium é na América Central, México e Venezuela, onde habita sobre solos arenosos nas savanas de "Pine Ridge" (Filgueiras 1989). Mesosetum filifolium foi recentemente encontrado em solo úmido em vegetação de Canga na Floresta Nacional de Carajás, Parauapebas, Pará, Brasil (Silva et al. 2016).

Mesosetum filifolium é morfologicamente relacionada à M. exaratum. No entanto, podem ser distintas pelas características apontadas sob M. exaratum.

Não há registro de contagens cromossômicas para M. filifolium.

Material selecionado: BRASIL. Pará: Parauapebas, Serra Norte, 0602'24"S, 50¹6'38"W, 11 Mar 2008, C.R. Martins 998 (UB). HONDURAS. Cayo: El Tigre Ranch, Mountain Pine Ridge, $17^{\circ} 03^{\prime} \mathrm{N}, 88^{\circ} 54^{\prime} \mathrm{W}, 7$ Mar 1969, R.R. Ines $189(\mathrm{~K})$. 
18. Mesosetum gibbosum Renvoize \& Filg., Kew Bulletin 39(1): 181. 1984. Fig. 4d

Tipo:-Brasil, Bahia, ca. 6 km N of Rio de Contas, 16 Jan 1974, Harley et al. 15086 (holótipo CEPEC[foto!]; isótipo K!, NY [foto!]).

Plantas perenes; cespitosas; rizomas presentes; estolhos ausentes. Folhas a maioria basais, dispostas na base do colmo. Lâminas foliares planas; membranáceas; lanceoladas; glabras, margens ciliadas. Inflorescências terminais; ráquis encerrando em espigueta desenvolvida, não aladas, 0,5 mm larg. Espiguetas solitárias dispostas em inflorescências racemiformes; 4,8-6,0 × 0,5-2,0 mm; inseridas em pedicelos com ápice truncado, ca 1,0 mm de compr.; dorsiventralmente comprimidas; pilosas, tricomas alvos. Glumas inferiores 3,5-4,5 $\times$ 0,5-1,5 mm; 3-nervadas, nervuras encontrando-se na região distal; simétricas; pilosas, tricomas com base não tuberculada distribuídos no terço proximal; ápice agudo; múticas. Glumas superiores 3,8-5,0 × 0,8-1,5 mm; 3nervadas, nervuras não encontrando-se na região distal; pilosas, com tricomas sem base tuberculada distribuídos ao longo das nervuras; múticas. Antécios inferiores neutros. Lemas inferiores com 2 tufos de tricomas de base não tuberculada no terço distal; nervuras não encontrando-se na região distal. Páleas inferiores ausentes. Antécios superiores 4,0-5,0 × 0,6-1,0 mm; cartáceos; ápice agudo; anteras vináceas.

Esta espécie foi descrita com base apenas em duas coleções provenientes da Chapada Diamantina no estado da Bahia. Recentemente esta espécie foi coletada em Tocantins, na região conhecida como Garganta, próximo à divisa com a Bahia. A revisão de herbários mostrou que esta espécie é comum no território baiano, estando disponíveis diversas coleções que contribuíram para a ampliação da compreensão da sua variação morfológica.

$\mathrm{Na}$ análise filogenética do Capítulo 1, M. gibbosum mostrou ser mais relacionada a $M$. penicillatum. São morfologicamente parecidas pela pilosidade vilosa das espiguetas. Todavia, são de fácil distinção. Mesosetum gibbosum tem espiguetas mais alongadas, 5-6 mm de comprimento e 
não possui tricomas de base tuberculada na gluma superior e lema inferior, enquanto $M$. penicillatum apresenta espiguetas mais curtas 4-5 $\mathrm{mm}$ de comprimento e tufos de tricomas de base tuberculada na na gluma superior e lema inferior.

É registrado o número cromossômico 2n = 24 para M. gibbosum (Ribeiro 2016).

Material selecionado: BRASIL. Bahia: Piatã, margem da estrada entre Piatã e Seabra, próximo à

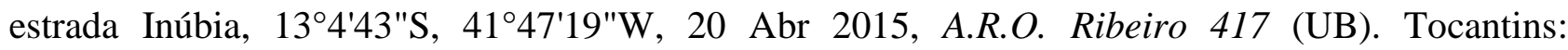
Dianópolis, região da Garganta, 09 Mai 2016, J.F.M. Valls et al. 16274 (CEN).

19. Mesosetum loliiforme (Hochst. ex Steud.) Chase, Botanical Gazette 51: 302. 1911. Fig. 2e

Tipo:-Panicum loliiforme Hochst. ex Steud. Synopsis Plantarum Glumacearum 1: 56. 1853. Suriname, s.d., F.W. Hostmann \& A. Kappler 1071 (holótipo P!; isótipos BM!, K,! U, US80740[foto!], US-1647160[foto!]).

Sinônimos:-Mesosetum elongatum Mez, Botanische Jahrbücher für Systematik, Pflanzengeschichte und Pflanzengeographie 56(125): 9. 1921. Brasil, Roraima, Serra do Mel, Jul 1909, Ule 8046 (holótipo B!; isótipo G[foto!], K!, L!). Mesosetum acuminatum Swallen, Brittonia 2(4): 384-385. 1937. Brasil, Goiás, vicinity of Goyaz, 20-22 Mar 1930, A. Chase 11403 (holótipo US-1500161[foto!]; isótipo K!, MO-245055[foto!], NY-381361[foto!]). Mesosetum altum Swallen, Brittonia 2(4): 383-384. 1937. Brasil, Maranhão, Barra do Corda to Grajahú, 1-5 Mar 1934, J.R. Swallen 3644 (holótipo US-1613938[foto!]; isótipo K!, MG[foto!], MO-245073[foto!], NY-381364 [foto!], RB[foto!], US-1613939[foto!]). Mesosetum curtifolium Swallen, Brittonia 2(4): 386-387. 1937. Brasil, Rio Grande de Norte, between Entremoz and Natal, 1 Jun 1934, J.R. Swallen 4784 (holótipo US-1613985[foto!]; isótipo MG, MO-245127[foto!]). Mesosetum latifolium Swallen, Brittonia 2(4): 382. 1937. Brasil, Maranhão, Carolina to San Antonio de Balsas, 20-25 Mar 1934, J.R. Swallen 4082 (holótipo US-1614031[foto!], isótipo B!, MG, MO245145[foto!], NY-381368[foto!]). Mesosetum longifolium Swallen, Brittonia 2(4): 388. 1937. 
Brasil, Maranhão, between Carolina and San Antonio de Balsas, 20-25 Mar 1934, J.R. Swallen 4109 (holótipo US-1614026[foto!]; isótipo MG, MO-245154[foto!]). Mesosetum pubescens Swallen, Brittonia 2(4): 385-386. 1937. Brasil, Maranhão, Carolina to San Antonio de Balsas, 20 Mar 1934, J.R. Swallen 4051 (holótipo US-1614028[foto!]; isótipo MG, MO-245190[foto!], NY381371[foto!]). Mesosetum tenuifolium Swallen, Brittonia 2(4): 387-388. 1937. Brasil, Pará, Ilha de Marajó, perto de Soure, 21-23 Jan 1934; J.R. Swallen 4976 (holótipo US-1614353[foto!], isótipo K!, MG, NY-381372[foto!], MO-245199[foto!], RB[foto!]).

Plantas perenes; cespitosas; rizomas presentes; estolhos presentes, emitidos horizontalmente. Folhas caulinares, dispostas ao longo do colmo. Lâminas foliares filiformes a planas; membranáceas; lanceoladas; glabras a vilosas, margens ciliadas com ou sem tricomas de base tuberculada. Inflorescências terminais; ráquis encerrando em espigueta desenvolvida, não aladas, 0,5 mm larg. Espiguetas solitárias dispostas em inflorescências racemiformes; 2,8-5,0 × 0,5-1,0 mm; inseridas em pedicelos com ápice truncado, ca 1,0 mm de compr.; dorsiventralmente comprimidas; pilosas, tricomas alvos. Glumas inferiores 2,0-3,8 $\times 0,5-1,0 \mathrm{~mm}$; 3-nervadas, nervuras encontrando-se na região distal; assimétricas; pilosas, tricomas com base não tuberculada distribuídos no terço proximal; ápice obtuso ou bilobado; múticas. Glumas superiores 2,0-3,5 × 0,8-1,0 mm; 3-nervadas, nervuras não encontrando-se na região distal; pilosas, com tricomas sem base tuberculada distribuídos ao longo das nervuras; múticas. Antécios inferiores neutros. Lemas inferiores com tricomas de base não tuberculada, distribuídos ao longo das nervuras laterais; nervuras não encontrando-se na região distal. Páleas inferiores ausentes. Antécios superiores 2,0-4,0 × 0,6-1,0 mm; cartáceos; ápice agudo; anteras vináceas.

Mesosetum loliiforme é a espécie com área de distribuição mais ampla no gênero, estendendo-se do Brasil Central às ilhas do Caribe (Swallen 1937, Filgueiras 1989). A localidade 
mais ao sul onde esta espécie tinha sido documentada foi no estado de Mato Grosso do Sul. Aqui, registra-se a sua ocorrência também no estado de São Paulo.

Mesosetum loliiforme apresenta grande plasticidade fenotípica. Filgueiras (1989) colocou sob a sinonímia de M. loliiforme oito espécies anteriormente descritas por Swallen (1937). Os epítetos descritos por Swallen (1937) foram distinguidos com base no comprimento, largura e pilosidade das lâminas foliares e tamanho do antécio. Filgueiras (1986) teve uma concepção mais ampla do conceito de $M$. loliiforme e sugeriu que tais caracteres não poderiam ser utilizados para a distinção dos táxons, mas que poderiam separar a espécie em duas variedades. Essas variedades não foram tratadas por Filgueiras (1989).

São conhecidos três níveis de ploidia para $M$. loliiforme, o tetraploide com $2 \mathrm{n}=16$ cromossomos, o hexaploide com $2 n=24$ e o octoploide com $2 n=32$ (Sousa 2014). Estes diferentes citótipos podem ajudar a explicar o amplo polimorfismo encontrado nesta espécie. Todavia, mais estudos envolvendo genética de populações, estudos reprodutivos e análises de citogenética molecular são necessários para uma compreensão mais acurada sobre a sua evolução.

Por ora, sabe-se que $M$. loliiforme é estreitamente relacionado às espécies $M$. annuum, $M$. arenarium, M. comatum e $M$. chlorostachyum (Capítulo 1). Para a distinção entre elas, ver comentários sob M. annuum. Análises da ornamentação do antécio superior conduzidas no Capítulo 4 (Silva et al. 2015) também demonstraram semelhança no agrupamento entre estes táxons.

Material selecionado: BRASIL. Bahia: Piatã, estrada Caetité p/ Bom Jesus da Lapa, 1351'2"S, 42³9'6"W, 21 Abr 2015, A.R.O. Ribeiro et al. 425 (UB). Goiás: Teresina de Goiás, próximo a

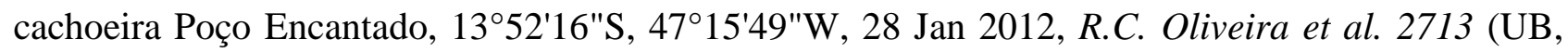
HUEFS); São Domingos, Parque Estadual Terra Ronca, 1340'48"S, 46²19'16"W, J.F.M. Valls et al. 15816 (CEN). Minas Gerais: Cristália, estrada de chão à 12 km da fábrica cerâmica de Cristália, após um córrego, 500m da borda da estrada descendo pelo lado esquerdo, após um cerrado, 1647'44"S, 4254'12"W, 05 Jun 2013, P.A. Reis et al. 335 (UB). São Paulo: Pedregulho, Estreito, 
Usina de Estreito, "Acampamento de Estreito", 2009'28"S, 47²16'38"W, 13 Jan 2004, D. Sasaki \& C. Sasaki 922 (FUEL, SPF). Tocantins: Cachoeirinha, a 19 Km do trevo de Tocantinópolis na BR 230, em direção à cidade, 6¹9'23"S, 4744'11"W, 05 Abr 2013, R.C. Oliveira et al. 2831 (UB, HUEFS).

20. Mesosetum longiaristatum Filg. Brittonia 39: 308. 1987. Fig. 3e

Tipo:-Brasil, Goiás, Flores de Goiás, fazenda São Luiz, ca.14³0"S, 4700"W, 3 Mai 1985, Almeida 1061 (holótipo IBGE!; isótipo CEN!, MO, RB, SP!, UEC, US).

Plantas anuais; cespitosas ou decumbentes; rizomas ausentes; estolhos ausentes. Folhas caulinares, dispostas ao longo do colmo. Lâminas foliares planas; membranáceas; lanceoladas; glabras, margens ciliadas sem tricomas de base tuberculada. Inflorescências terminais; ráquis encerrando em espigueta desenvolvida, aladas, 0,8-2,2 $\mathrm{mm}$ larg. Espiguetas solitárias dispostas em inflorescências racemiformes; 2,8-5,0 × 0,5-1,0 mm; inseridas em pedicelos com ápice truncado, ca 1,0 mm de compr.; lateralmente comprimidas; pilosas, tricomas alvos. Glumas inferiores 2,85,0 × 0,5-1,0 mm; 3-nervadas, nervuras encontrando-se na região distal; simétricas; glabras; ápice bilobado; aristadas, aristas 5-25 mm de compr. Glumas superiores 2,5-4,5 × 0,5-1,0 mm; 5nervadas, nervuras não encontrando-se na região distal; pilosas, com ou sem 1 tufo de tricomas sem base tuberculada no terço distal; múticas, mucronadas ou aristadas, até 1,0 mm. Antécios inferiores masculinos ou neutros. Lemas inferiores com 2 tufos de tricomas de base não tuberculada no terço distal; nervuras não encontrando-se na região distal. Páleas inferiores presentes ou ausentes. Antécios superiores 3,0-3,5 × 0,6-1,0 mm; cartáceos; ápice agudo; anteras vináceas.

Mesosetum longiaristatum é conhecida apenas para o estado de Goiás e foi relatada por Oliveira et al. (2009), juntamente com M. agropyroides e M. alatum, como uma das espécies raras do Brasil por causa do exíguo número de coletas à época -apenas duas- ambas na Chapada dos 
Veadeiros, Goiás. Recentemente foi encontrada outra população de M. longiaristatum no parque Estadual de Terra Ronca. Portanto, há duas populações conhecidas desta espécie na natureza.

As populações de $M$. longiaristatum apresentam níveis de ploidia distintos: o diploide $2 \mathrm{n}=8$ cromossomos e o hexaploide $2 \mathrm{n}=24$ cromossomos (Ribeiro 2013, Ribeiro et al. 2015). A análise filogenética molecular (Capítulo 1) revelou que a origem destes citótipos podem ser distintas: o citótipo diploide é mais relacionado à $M$. bifarium $(2 \mathrm{n}=8$, diploide $)$ e $M$. elytrochaetum $(2 \mathrm{n}=24$, hexaploide), enquanto que o citótipo hexaploide, à $M$. chaseae $(2 \mathrm{n}=24$, hexaploide), $M$. bifarium ( $2 \mathrm{n}=16$, tetraploide), . compressum $(2 \mathrm{n}=16$, tetraploide) e $M$. alatum $(2 \mathrm{n}=8$, diploide). Apesar de filogeneticamente distintas, não há descontinuidade morfológica que permita a separação fenética entre as duas populações de M. longiaristatum.

A característica exclusiva desta espécie é a presença de um apêndice glanduloso na base da espigueta (Filgueiras 1989, Ribeiro 2013). A sua função ainda é desconhecida, no entanto, é provável que esteja relacionado à dispersão zoocórica. Além disso, é distinta das demais espécies com as quais é relacionada, pelo hábito de vida anual e cespitoso, enquanto as demais são perenes e estoloníferas.

Material selecionado: BRASIL. Goiás: Teresina de Goiás, $20 \mathrm{Km}$ de Teresina, $18 \mathrm{~km}$ a partir da 1a. ponte, na estrada Teresina-Palmas à direita ( $2 \mathrm{~km}$ antes do córrego Siriema), $13^{\circ} 37^{\prime} 44^{\prime \prime S}$, 43²9'19"W, 19 Mar 2013, R.C. Oliveira et al. 2816 (HUEFS, UB); São Domingos, Parque Estadual Terra Ronca, ao longo da estrada de acesso à Caverna Angélica, desde a GO-108, 13³0'52"S, 46²3'19"W, 16 Mai 2013, J.F.M. Valls et al. 15841 (CEN). 
21. Mesosetum pappophorum (Nees) Kuhlm. Commissão de Linhas Telegraphicas, Botanica 67(11): 90. 1922. Fig. 3h, 4e

Tipo:-Panicum pappophorum Nees A. Flora Brasiliensis seu Enumeratio Plantarum 2(1): 104105. 1829. Brasil, Piaui, in campis mioso dictis prov. Piauhiensis, s.d., K.F.P. von Martius s.n. (lectótipo M-3826; isolectótipo US-1781550[foto!]).

Sinônimos:-Panicum pappophorum var. tenerius Döll, Flora Brasiliensis 2(2): 175. 1877. nom. inval., baseado em Panicum pappophorum Nees A.

Plantas anuais; cespitosas ou decumbentes; rizomas ausentes; estolhos ausentes. Folhas caulinares, dispostas ao longo do colmo. Lâminas foliares planas; membranáceas; lanceoladas; glabras a pilosas, margens ciliadas com ou sem tricomas de base tuberculada. Inflorescências terminais; ráquis encerrando em espigueta desenvolvida, não aladas, 0,5 mm larg. Espiguetas solitárias dispostas em inflorescências racemiformes; $2,8-3,5 \times 0,5-1,0 \mathrm{~mm}$; inseridas em pedicelos com ápice truncado, ca 1,0 mm de compr.; dorsiventralmente comprimidas; pilosas, tricomas alvos ou vináceos. Glumas inferiores 2,2-2,5 × 0,5-0,8 mm;3-5-nervadas, nervuras encontrando-se na região distal; assimétricas; pilosas, tricomas com base não tuberculada distribuídos no terço proximal; ápice agudo; múticas. Glumas superiores 2,5-3,0 × 0,8 mm; 5-nervadas, nervuras anastomosadas na região distal; pilosas, com tricomas sem base tuberculada distribuídos ao longo das nervuras; múticas. Antécios inferiores neutros. Lemas inferiores com 2 tufos de tricomas de base não tuberculada no terço distal; nervuras anastomosadas na região distal. Páleas inferiores presentes. Antécios superiores 2,0-3,0 × 0,6-1,0 mm; coriáceos; ápice apiculado; anteras vináceas.

Mesosetum pappophorum é uma espécie anual que ocorre principalmente em áreas de Caatinga no Nordeste do Brasil, Goiás e Minas Gerais. Esta espécie também foi registrada para a flora da Venezuela. 
Mesosetum pappophorum foi relacionada morfologicamente a $M$. annuum e $M$. chlorostachyum por Swallen (1937), por apresentarem hábito de vida anual. Já Filgueiras (1989) comentou a afinidade morfológica desta espécie com $M$. exaratum e $M$. filifolium, por compartilharem algumas semelhanças na pilosidade da espigueta. Contudo, a análise filogenética (Capítulo 1) mostrou que esta espécie se relaciona com M. sclerochloa. Estas duas espécies foram encontradas convivendo no mesmo ambiente, ambas apresentam ciclo de vida anual e hábito decumbente, espiguetas com glumas e lema inferior com nervuras anastomosadas conspícuas. São distinguidas pela compressão e pilosidade da espigueta. Mesosetum pappophorum apresenta espiguetas pilosas e dorsalmente comprimidas, enquanto que em M. sclerochloa as espiguetas são glabrescentes e lateralmente comprimidas.

É registrado o número cromossômico 2n = 8 para M. pappophorum (Ribeiro 2016).

Material selecionado: BRASIL. Goiás: Flores de Goiás, 23 Jan 2014, J.FM. Valls et al. 15949 $(\mathrm{CEN})$.

22. Mesosetum penicillatum Mez. Repertorium Specierum Novarum Regni Vegetabilis 15: 124. 1918. Fig. 2b

Tipo:-Brasil, Piauí, 1836-1841, Gardner 2979 (holótipo B!; isótipos BM!, G[foto!], GH, HUEFS41903!, K!, MO-228025, NY[foto!], OFX!, P!, US-825702[foto!], US-1126075[foto!]).

Sinônimos:-Panicum pappophorum Nees B, Flora Brasiliensis 2(2): 175. 1877. Brasil, Minas Gerais, between Jequitinhonha and São Francisco, s.d., Martius s.n. (holótipo M[foto!]; isótipos US-80896[foto!]). Panicum pappophorum var. rigidum Döll, Flora Brasiliensis 2(2): 175. 1877. Baseado em Panicum pappophorum Nees B. Mesosetum elegans Swallen, Brittonia 2(4): 375-376. 1937. Brasil, Mato Grosso, collected on alluvial ground by Rio Ibo, NW of Sao Lourenço, 10 Apr 1930, Chase 11956 (holótipo US-1500454[foto!]; isótipos MO[foto!], RB[foto!], US[foto!]). 
Plantas perenes; cespitosas; rizomas presentes; estolhos ausentes. Folhas a maioria basais, dispostas na base do colmo. Lâminas foliares planas; membranáceas; lanceoladas; glabras a pilosas, margens ciliadas com ou sem tricomas de base tuberculada. Inflorescências terminais; ráquis encerrando em espigueta desenvolvida, não aladas, 0,5-1,0 $\mathrm{mm}$ larg. Espiguetas solitárias dispostas em inflorescências racemiformes; 4,5-5,8 × 0,5-1,0 mm; inseridas em pedicelos com ápice truncado, ca 1,0 $\mathrm{mm}$ de compr.; dorsiventralmente comprimidas; pilosas, tricomas alvos. Glumas inferiores 3,0-3,5 × 0,5-1,0 mm; 3-nervadas, nervuras encontrando-se na região distal; simétricas; pilosas, tricomas com base não tuberculada no terço proximal; ápice naviculado; múticas. Glumas superiores 3,8-4,5 × 0,8-1,2 mm; 5-nervadas, nervuras encontrando-se na região distal; pilosas, com 2 tufos de tricomas de base tuberculada no terço distal; múticas. Antécios inferiores masculinos. Lemas inferiores com 2 tufos de tricomas de base tuberculada no terço distal; nervuras anastomosadas na região distal. Páleas inferiores presentes. Antécios superiores 3,0-3,6 × 0,5-1,0 mm; cartáceos; ápice agudo; anteras vináceas.

Ocorre em áreas de Cerrado e Caatinga do Brasil Central e Bolívia. Em quase todas as exsicatas examinadas pode ser observada a ausência de lâminas foliares e bainhas foliares carbonizadas, indicando que é possível que o florescimento de $M$. penicillatum esteja relacionado às queimas sazonais onde ela ocorre.

Mesosetum penicillatum assemelha-se morfologicamente a M. agropyroides e M. gibbosum, esta última está mais próxima de M. penicillatum (Capítulo 1). Distinguem-se pelas características apontadas sob M. agropyroides e M. gibbosum.

Não há registros de contagens cromossômicas para M. penicillatum.

Material selecionado: BRASIL. Tocantins: Estação Ecológica Serra Geral do Tocantins, 12 Dez 2014, D.P. Silva et al. 329 (UB). 
23. Mesosetum pittieri Hitchc. Proceedings of the Biological Society of Washington 40: 85. 1927. Tipo:-PANAMÁ, Sabana de Juan Corso, near Chepó, 11 Ago 1911, H. Pittier 4751 (holótipo US679914[foto!]).

Plantas anuais; decumbentes, enraizando-se nos nós inferiores; rizomas ausentes; estolhos ausentes. Folhas a maioria basais, dispostas na base do colmo. Lâminas foliares planas; membranáceas; lanceoladas; glabras a pilosas, margens ciliadas com ou sem tricomas de base tuberculada. Inflorescências terminais; ráquis encerrando em espigueta desenvolvida, aladas, 0,8-1,2 mm larg. Espiguetas solitárias dispostas em inflorescências racemiformes; 4,0-5,5 × 0,8-1,5 mm; inseridas em pedicelos com ápice truncado, ca 1,0 mm de compr.; lateralmente comprimidas; glabrescente, tricomas alvos. Glumas inferiores 3,0-5,0 × 0,5-1,0 mm; 3-nervadas, nervuras anastomosadas na região distal; simétricas; pilosas, tricomas com base não tuberculada no terço proximal; ápice naviculado; múticas. Glumas superiores 4,5-5,0 × 0,8-1,0 mm; 5-nervadas, nervuras anastomosadas na região distal; pilosas, com tricomas sem base tuberculada esparsados; múticas. Antécios inferiores neutros. Lemas inferiores com 1 tufo de tricomas de base não tuberculada no terço distal; nervuras anastomosadas na região distal. Páleas inferiores presentes. Antécios superiores 3,0-4,5 × 0,5-1,0 mm; coriáceos; ápice acuminado; anteras vináceas.

Espécie conhecida apenas da América Central, onde habita solos arenosos e pedregosos.

Swallen (1937) e Filgueiras (1989) relacionaram M. pittieri a M. sclerochloa. De fato, são plantas morfologicamente semelhantes e a proximidade entre elas foi corroborada na análise filogenética do Capítulo 1 e no agrupamento baseado na ornamentação do antécio superior do Capítulo 4 (Silva et al. 2015).

Mesosetum pittieri e M. sclerochloa são espécies anuais que compartilham características, tais como, espiguetas lateralmente comprimidas, ápice das glumas e lema inferior com nervuras anastomosadas conspícuas e antécio superior com apenas uma papila simples por célula epidérmica 
(Capítulo 4, Silva et al. 2015). Todavia, o comprimento relativo da gluma inferior em relação ao antécio superior é suficiente para distingui-las. Enquanto que em $M$. pittieri, a gluma inferior é mais longa que o antécio, em $M$. sclerochloa, a gluma inferior é mais curta que o antécio.

É registrado o número cromossômico 2n = 16 para M. pittieri (Pohl \& Davidse 1971).

Material selecionado: COSTA RICA. Prov. Guanacaste: Hda. Murciélago, $2 \mathrm{~km} \mathrm{~W}$ of CIA s. of La Cruz, 26 Jul 1971, R.W. Pohl 12648 (K, MO).

24. Mesosetum rottboellioides (Kunth) Hitchc. Contributions from the United States National Herbarium 12(6): 211. 1909. Fig. 5b

Tipo:-Panicum rottboellioides Kunth. Nova Genera et Species Plantarum 1(4): 96, t. 32. 1815[1816]. VENEZUELA, Amazonas, between Maypures and Mountain Sipapo, Abr, Humboldt \& Bonpland s.n. (holótipo P!; isótipo US-80960[foto!]).

Sinônimos:-Panicum lolium Nees, Flora Brasiliensis seu Enumeratio Plantarum 2(1): 102-103. 1829. Brasil, Piaui, s.d., Martius s.n. (holótipo M[foto!]; isótipos B!, US-80741[foto!]). Mesosetum discolor Mez, Botanische Jahrbücher für Systematik, Pflanzengeschichte und Pflanzengeographie 56(125): 8. 1921. Brasil, Bahia, Serra de Ignacio, Ule 7492 (holótipo B!; isótipo K!).

Plantas perenes; cespitosas; rizomas ausentes; estolhos presentes, raros, emitidos verticalmente. Folhas a maioria basais, dispostas na base do colmo. Lâminas foliares planas; membranáceas; linear-lanceoladas; glabras a pilosas, margens ciliadas com ou sem tricomas de base tuberculada. Inflorescências terminais; ráquis encerrando em espigueta desenvolvida, não aladas, 0,5 mm larg. Espiguetas solitárias dispostas em inflorescências racemiformes; 4,0-4,5 × 0,8-1,2 $\mathrm{mm}$; inseridas em pedicelos com ápice oblíquo, ca 1,0 $\mathrm{mm}$ de compr.; dorsiventralmente comprimidas; pilosas, tricomas ferrugíneos, raro amarelo-pálidos. Glumas inferiores 2,5-3,5 × 0,5-1,0 mm; 3-nervadas, nervuras não encontrando-se na região distal; simétricas; pilosas, tricomas 
com base não tuberculada distribuídas ao longo das nervuras laterais; ápice arredondado ou agudo; múticas. Glumas superiores 3,5-4,2 × 0,8-1,0 mm; 5-nervadas, nervuras não encontrando-se na região distal; pilosas, tricomas com base não tuberculada distribuídas ao longo das nervuras; múticas. Antécios inferiores neutros. Lemas inferiores com 2 tufos de tricomas de base não tuberculada no terço distal; nervuras não encontrando-se na região distal. Páleas inferiores ausentes. Antécios superiores 3,0-3,5 × 0,5-1,0 mm; cartáceos; ápice agudo; anteras vináceas.

Mesosetum rottboellioides distribui-se pelo Norte e Nordeste do Brasil, Venezuela e Guiana. Forma um grupo bem homogêneo com M. cayennnense e M. ferrugineum (Swallen 1937, Filgueiras 1989, Capítulo 1, Capítulo 4-Silva et al. 2015). Diferencia-se destas pelas características enumeradas sob M. cayennnense e M. ferrugineum. Além disso, é a espécie mais próxima de Mesosetum sp. nov. 1, descrita no Capítulo 3 desta tese.

É registrado o número cromossômico 2n = 20 para M. rottboellioides (Sousa 2014, Ribeiro 2016).

Material selecionado: BRASIL. Bahia: Piatã, margem da estrada entre Piatã e Seabra, próximo a estrada Inúbia, 139'6"S, 41ํ6'22"W, Abr 2015, A.R.O. Ribeiro \& J.E.Q. Faria 420 (UB). Minas Gerais: Grão Mogol, sentido Cristália, embaixo da ponte do rio Itacambirucu, após o Trevo de Grão Mogol, 16³5'35"S, 4254'1"W, 5 Jun 2013, P.A. Reis et al. 331 (UB). 
25. Mesosetum sp. nov. 1 A.S. Silva \& R.C. Oliveira, sp. nov.

Tipo:-GUIANA FRANCESA: Mont Saint-Marcel, zone Sud-est du massif, $2^{\circ} 23^{\prime} 00^{\prime \prime N}$, $53^{\circ} 00^{\prime} 20^{\prime \prime} \mathrm{W}$, atl. 300m, $22 \mathrm{Jul}$ 2002, fl. and fr., J.J. de Granville, L. Aliker \& C. Sarthou 15423 (holotype: CAY!; isotype: P!, B!, K!, MO, U, US).

Plantas anuais; cespitosas; rizomas ausentes; estolhos ausentes. Folhas a maioria basais, dispostas na base do colmo. Lâminas foliares planas; membranáceas; linear-lanceoladas; glabras a pilosas, margens ciliadas. Inflorescências terminais; ráquis encerrando em espigueta em desenvolvimento, não aladas, 0,2 mm larg. Espiguetas solitárias dispostas em inflorescências racemiformes; $3,0-4,5 \times 0,8-1,0 \mathrm{~mm}$; inseridas em pedicelos com ápice oblíquo, ca 1,5-2,0 mm de compr.; dorsiventralmente comprimidas; pilosas, tricomas ferrugíneos, raro amarelo-pálidos. Glumas inferiores $1,8-2,5 \times 0,8-1,0 \mathrm{~mm} ; 5$-nervadas, nervuras não encontrando-se na região distal; simétricas; pilosas, tricomas com base não tuberculada distribuídas ao longo das nervuras laterais; ápice; múticas. Glumas superiores 3,0-4,5 × 0,7-1,0 mm; 5-nervadas, nervuras não encontrando-se na região distal; pilosas, tricomas com base não tuberculada distribuídas ao longo das nervuras; múticas. Antécios inferiores neutros. Lemas inferiores com tricomas de base não tuberculada no terço distal; nervuras não encontrando-se na região distal. Páleas inferiores ausentes. Antécios superiores 2,0-2,4 × 0,5-1,0 mm; cartáceos; ápice agudo; anteras vináceas.

Mesosetum sp. nov. 1 é endêmica da Guiana Francesa.

É próxima de $M$. rottboellioides, M. cayennense e M. ferrugineum (Capítulo 1). Para a distinção entre essas espécies e mais detalhes sobre Mesosetum sp. nov. 1, ver Capítulo 3.

Não há registro de contagens cromossômicas para Mesosetum sp. nov. 1. 
Material selecionado: GUIANA FRANCESA. Inselbergs du haut Marouini - A: Inselbergs de la D.Z., 02 $36^{\prime} 30^{\prime \prime} \mathrm{N}, 54^{\circ} 01^{\prime} 45^{\prime \prime}$, alt. 220 m, 21 Jun 2004, J.J. de Granville \& F. Crozier 16271 (CAY!, P!, MO, US).

26. Mesosetum sclerochloa (Trin.) Hitchc., Contributions from the United States National Herbarium 12(6): 212. 1909. Fig. 2f

Tipo:-Panicum sclerochloa Trin., Species Graminum 3(24): , t. 283. 1829-1830. Brazil, Mato Grosso, Cuiaba, in humidis graminosis, Fev 1827, G.H. von Langsdorff s.n. (holótipo LE-TRIN0944.02 [foto!]; isótipo LE-TRIN-0944.01 [foto!], US-80980 [foto!])

Plantas anuais; decumbentes, enraizando-se nos nós inferiores; rizomas ausentes; estolhos ausentes. Folhas a maioria basais, dispostas na base do colmo. Lâminas foliares planas; membranáceas; lanceoladas; glabras, margens ciliadas com ou sem tricomas de base tuberculada. Inflorescências terminais; ráquis encerrando em espigueta desenvolvida, aladas, 0,8-1,2 mm larg. Espiguetas solitárias dispostas em inflorescências racemiformes; 4,5-6,0 × 0,8-1,5 mm; inseridas em pedicelos com ápice truncado, ca 1,0 mm de compr.; lateralmente comprimidas; glabrescente, tricomas alvos. Glumas inferiores 5,0-6,0 × 0,5-1,0 mm; 5-nervadas, nervuras anastomosadas na região distal; simétricas; pilosas, tricomas com base não tuberculada no terço proximal; ápice naviculado; múticas. Glumas superiores 4,5-5,3 × 0,8-1,0 mm; 5-nervadas, nervuras anastomosadas na região distal; pilosas, com tricomas sem base tuberculada, esparsados; múticas. Antécios inferiores neutros. Lemas inferiores com 1 tufo de tricomas de base não tuberculada no terço distal; nervuras anastomosadas na região distal. Páleas inferiores presentes. Antécios superiores 3,5-4,5 × 0,5-1,0 mm; coriáceos; ápice acuminado; anteras vináceas.

Filgueiras (1986) expressou a dificuldade na descrição de Mesosetum sclerochloa, pois naquela época só o holótipo estava disponível, o qual foi coletado por Langsdorff em 1821 em 
Cuiabá, Mato Grosso, Brasil. Mesosetum sclerochloa foi recoletado por Valls et al. (2009) em Alvorada do Norte, Goiás, após 187 anos da coleta original e a 1050 km Cuiabá. Outro espécime foi coletado por Rua et al. 958 (UB) em Abril de 2011, em Nossa Senhora do Livramento no estado do Mato Grosso.

Em Flores de Goiás-Goiás, M. sclerochloa foi coletada diversas vezes no período de 2012 a 2016, o que indica que a sua raridade, destacada anteriormente, é resultado da precária documentação desta espécie em herbários e não por causa de sua escassa ocorrência.

Mesosetum sclerochloa forma extensas populações em áreas abertas no Cerrado brasileiro. É encontrada em intenso florescimento e frutificação nos meses de fevereiro, março e abril.

É próxima de M. pittieri, sendo distinguidas pelos caracteres informados sob esta espécie.

É registrado o número cromossômico 2n = 16 para M. sclerochloa (Sousa 2014, Ribeiro 2016).

Material selecionado: BRASIL. Goiás: Flores de Goiás, 14²4'2.9"S, 47³'2.2"W, 02 Mar 2013, A.S. Silva et al. 266 (UB); 14²3'56"S, 47'1"W, 14 Abr 2012, R.C. Oliveira \& A.R.O. Ribeiro 2739 (UB). Mato Grosso: Nossa Senhora do Livramento, 16²'33"S, 56² 19'54"W, 16 Abr 2011, G.H. Rua et al. 958 (UB).

27. Mesosetum wrightii Hitchc., Contributions from the United States National Herbarium 12(6): 211-212. 1909.

Tipo:-CUBA, Pinar del Río, Dayaninguas, s.d., C. Wright 3859 (holótipo US-559961[foto!]; isótipo GH, NY-71103[foto!], NY-71104[foto!]).

Plantas perenes; rizomas ausentes; estolhos presentes. Folhas a maioria basais, dispostas na base do colmo. Lâminas foliares planas; membranáceas; linear-lanceoladas; glabras, margens ciliadas com ou sem tricomas de base tuberculada. Inflorescências terminais; ráquis encerrando em 
espigueta desenvolvida, não aladas, 0,5 mm larg. Espiguetas solitárias dispostas em inflorescências racemiformes; 3,2-4,5 × 0,8-1,0 mm; inseridas em pedicelos com ápice truncado, ca 1,0 $\mathrm{mm}$ de compr.; lateralmente comprimidas; glabrescente, tricomas alvos. Glumas inferiores 2,0-2,6 $\times$ 0,5-0,8 mm; 5-nervadas, nervuras não encontrando-se na região distal; simétricas; glabrescentes; ápice bidentado; múticas. Glumas superiores 3,5-4,0 × 0,8-1,0 mm; 7-9-nervadas, nervuras anastomosadas na região distal; pilosas, com 1 tufo de tricomas de base não tuberculada no terço distal; múticas. Antécios inferiores neutros. Lemas inferiores com 1 tufo de tricomas de base não tuberculada no terço distal; nervuras anastomosadas na região distal. Páleas inferiores ausentes. Antécios superiores 2,5-3,0 × 0,5-0,8 mm; coriáceos; ápice acuminado; anteras vináceas.

Espécie endêmica de Cuba. Foi relacionada por Filgueiras (1989) a M. sect. Penicillata. O autor destacou a proximidade morfológica desta espécie com M. agropyroides, M. blakei e M. penicillatum.

A filogenia apresentada no Capítulo 1 corrobora apenas a proximidade com M. blakei. Ambas as espécies só ocorrem na América Central, mas podem ser distinguidas pelo hábito de crescimento e tamanho relativo das glumas. Mesosetum blakei é uma planta essencialmente ereta e com as glumas subiguais, enquanto que $M$. wrightii é estolonífera e apresenta gluma inferior conspicuamente menor que a gluma superior.

Não há registro de contagens cromossômicas para $M$. wrightii.

Material selecionado: CUBA. Pinar del Río: Pinar del Barreto, 01 Out 1920, E.L. Ekman 11552 (K). 


\section{Referências}

Bentham, G. \& Hooker, J.D. (1883) Genera Plantarum. L. Reeve \& Co., London, pp 1012-1215.

Chase, M.A. (1911) Notes on genera of Paniceae IV. Proceedings of the Biological Society of Washington 24: 103-160.

Döll, J.C. (1877) Gramineae I. Paniceae. In: Martius, C.F.P. (Ed.) Flora Brasiliensis 2: 33-358.

Fidalgo, O. \& Bononi, V. L. R. (1989) Técnica de coleta, preservação e herborização de material botânico. Série Documentos. Instituto de Botânica, São Paulo, 62 pp.

Filgueiras, T.S. (1986) O gênero Mesosetum Steudel (Gramineae: Paniceae). Tese de Doutorado. Universidade Estadual de Campinas, Campinas, 344 pp.

Filgueiras, T.S. (1989) Revisão de Mesosetum Steudel (Gramineae: Paniceae). Acta Amazônica 19: $47-114$.

Giussani, L.M., Cota-Sanchez, H., Zuloaga, F.O. \& Kellogg, E.A. (2001) A molecular phylogeny of the grass subfamily Panicoideae (Poaceae) shows multiple origins of C4 photosynthesis. American Journal of Botany 88: 1993-2012.

Grass Phylogeny Working Group (GPWG) (2011) New grass phylogeny resolves deep evolutionary relationships and discovers $\mathrm{C}_{4}$ origins. New Phytologist 193: 304-312.

Hackel, E. (1897) Bifaria, eine neue Section der Gattung Panicum. Oesterreichische Botanische Zeitschrift 47: 73-77.

Hitchcock, A.S. (1909) The grasses of Cuba. Contributions from the United States National Herbarium 12 (6): 1-474.

Jørgensen, P.M., Nee, M.H. \& Beck, S.G. (2014) Catálogo de las plantas vasculares de Bolivia. Monographs in Systematic Botany from the Missouri Botanical Garden 127: 1-1744.

Kuntze, O. (1898) Revisio Genera Plantarum. Leipzig 3(2), 576 pp.

Meirelles, A.C.S., Monteiro, E.R., Silva, L.A.C., Silva, D., Santos, S.A., Oliveira-Collet, S.A., Mangolin, C.A. \& Machado, M.F.P.S. (2015) Esterase polymorphism for genetic diversity 
analysis of some accessions of a native forage grass, Mesosetum chaseae Luces, from the Brazilian Pantanal. Tropical Grasslands 3: 194-204.

Mez, C. (1918) Sacciolepis, Mesosetum, Thrasia, Ichnanthus genera speciebus novis aucta. Repertorium Specierum Novarum Regni Vegetabilis 15: 122-133.

Nees, C.G. (1829) Agrostologia brasiliensis. In: Martius, C.F.P. (Ed.) Flora Brasiliensis seu Enumeratio Plantarum 2. J.G. Cottae, Stuttgart \& Tübingen, pp. 1-608.

Oliveira, R.P., Longhi-Wagner, H.M., Filgueiras, T.S., Mota, A.C. \& Viana, P.L. (2009) Poaceae. In: Giulietti, A.M., Rapini, A., Andrade, M.J.G., Queiroz, L.P. \& Silva, J.M.C. (Eds.) Plantas Raras do Brasil. Conservação Internacional, Universidade Estadual de Feira de Santana, Belo Horizonte-MG, 496 pp.

Pilger, R. (1940) Gramineae. In Engler, A \& Prantl, K. Die Natürlichen Pflanzenfamilen. Leipzig., Wilhelm Engelmann 2ed, 208 pp.

Pohl, R.W. \& Davidse, G. (1971) Chromosome numbers of Costa Rican grasses. Brittonia 23: 293324.

Radford, A.E., Dickison, W.C., Massey, J.R. \& Bell, C.R. (1974) Vascular Plant Systematics. Harper \& Row, New York, 891 pp.

Renvoize, S. (1998) Gramíneas de Bolivia. Royal Botanic Garden, Kew, 644 pp.

Ribeiro, A.R.O. (2016) Estudos cromossômicos e reprodutivos em espécies de Mesosetum Steud. (Poaceae: Paspaleae). Tese de Doutorado. Universidade de Brasília, Brasília-DF, 116 pp.

Silva, L.A.C., Pagliarini, M.S., Santos, S.A., Silva, N. \& Souza, V.F. (2012) Chromosome number, microsporogenesis, microgametogenesis, and pollen viability in the Brazilian native grass Mesosetum chaseae (Poaceae). Genetics and Molecular Research 11: 4100-4109.

Silva, A.S., Ribeiro, A.R.O., Sousa, M.W.S., Fagg, C.W., Falcão, R. \& Oliveira, R.C. (2015) Micromorphology of the upper anthecium in Mesosetum Steud. and related genera (Poaceae, Arthropogoninae) and its taxonomic applications. Rodriguésia 66: 645-657. 
Silva, A.S., Villarroel, D., Ribeiro, A.R.O. \& Oliveira, R.C. (2016) Eleven new records of little known taxa of Mesosetum and Paspalum (Poaceae) from Brazil and Bolivia. Phytotaxa 268 (1): 069-079.

Sousa, M.W.S. (2014) Citogenética e morfologia de espécies de Mesosetum Steud. (Poaceae, Paspaleae). Dissertação de Mestrado.Universidade de Brasília, Brasília-DF. 76 pp.

Steudel, E.G. von (1854) Gramineae. Synopsis Plantarum Glumacearum 1. J. B. Metzler, Stuttgartle, 474 pp.

Swallen, J.R. (1937) The grass genus Mesosetum. Brittonia 2: 363-392.

Thiers, B. (2017; continuously updated) Index Herbariorum: A global directory of public herbaria and associated staff. New York Botanical Garden's Virtual Herbarium. Available from: http://sweetgum.nybg.org/ih/ (acesso em 20/01/2017).

Trinius, C.B. (1826) De Graminibus Paniceis. Dissertatio botanica altera. Impensis Academiae Imperialis Scientiarum, Saint Petersburg, 289 pp.

Trinius, C.B. (1834) Panicearum genera. Memories de l'Academie de Sciences de SaintPetersbourg. Section des Sciences Physique et Naturelle 3(6): 1-267.

Valls, J.F.M., Ramos, D.M., Peñaloza, A.P.S. \& Santos, S. (2009) Nota sobre a ocorrência e distribuição geográfica de Mesosetum sclerochloa (Trin.) Hitchc., gramínea brasileira com raríssimas coletas, Resumos do 60 Congresso Nacional de Botânica (on DVD). EDUNEB, Salvador, $666 \mathrm{pp}$. 
Capítulo 3

A new species of Mesosetum Steud. (Poaceae, Paspaleae) from French Guiana

Adequado às normas da revista Phytotaxa 


\title{
Capítulo 3
}

\section{A new species of Mesosetum Steud. (Poaceae, Paspaleae) from French Guiana}

\begin{abstract}
A new species, Mesosetum sp. nov. 1, is here described and illustrated. It is an annual species morphologically related to $M$. cayennense and $M$. rottboellioides, but can be recognized by the size of racemes and pedicels, size and pilosity of glumes, and length of lower lemma and upper floret. It is found in rocky savannas and humid areas of French Guiana, locally called Inselbergs.
\end{abstract}

Key words: Arthropogoninae, Mesosetum sect. Mesosetum, Inselbergs vegetation, Neotropics.

\section{Introduction}

Mesosetum Steud. (1854) is a Neotropical genus represented by 25 species distributed from Mexico to northern Argentina. French Guiana holds four species of Mesosetum, including the type species, M. cayennense Steud. (Filgueiras 1989, Funk et al. 2007).

This genus belongs to tribe Paspaleae Presl (1830: 208) in the subfamily Panicoideae (Soreng et al. 2015). It is part of the subtribe Arthropogoninae Butzin, along with 15 other American genera (Morrone et al. 2012). Mesosetum is distinguished from other Arthropogoninae genera by raceme-like solitary terminal inflorescence, spikelets with the first glume adaxial to rachis, glume and lower lemma with tuffs of hairs and caryopsis with linear hilum (Filgueiras 1989). 
The latest revision of Mesosetum (Filgueiras 1989) recognizes five sections in the genus: $M$. sect. Mesosetum, M. sect. Loliiformia, M. sect. Sclerochloae, M. sect. Penicillata and M. sect. Bifaria. However, these sections are not monophyletic (unpublished data).

During the review of herbaria for a sinopsis of Mesosetum an undescribed taxon was detected. The vouchers are deposited in B, K and P European herbaria and in the Cayenne (CAY) herbarium. This new species belongs to section Mesosetum according to the classification of Filgueiras (1989). The section is recognized by spikelets covered by ferrugineous trichomes and lower palea absent. The species that belong to $M$. sect. Mesosetum form a very homogeneous group. The objective of the present work is to describe a new species of Mesosetum from French Guiana, and to compare it with allied taxa belonging to M. sect. Mesosetum.

\section{Taxonomy}

Mesosetum sp. nov. 1. A.S. Silva \& R.C. Oliveira, sp. nov., (Figs. 1, 2)

Annual; culms 25-40 cm tall, slender, no branching; nodes glabrous; racemes 3-6 cm long; raceme rachis ending in an aborted spikelets; pedicels 1.5-2.0 mm long; spikelets 3.0-4.5 $\mathrm{mm}$ long, dorsiventrally compressed; lower glume 1.8-2.5 mm long, apex acute, pilose in the lower portion on the back; upper glume $3.0-4.5 \mathrm{~mm}$ long, apex acuminated silky-pilose on the back following the nerves; lower lemma 2.5-3.1 mm long, 5-7-nerved, silky-pilose on the margins with a few thicker trichomes in the median portion; upper floret 2-2.4 mm long, narrowly ellipsoid. Differs from M. cayennense and M. rottboelliodes in annual life form, racemes ending in a meristematic apex, pedicels 1.5-2.0 mm long, upper floret 2.5-3.1 mm long. 
Type:-FRENCH GUIANA: Mont Saint-Marcel, zone Sud-est du massif, $2^{\circ} 23^{\prime} 00^{\prime \prime N}, 53^{\circ} 00^{\prime} 20^{\prime \prime} \mathrm{W}$, atl. 300m, 22 Jul 2002, fl. and fr., J.J. de Granville, L. Aliker \& C. Sarthou 15423 (holotype: CAY!; isotype: P!, B!, K!, MO, U, US)

Annual. Culms 25-40 cm tall, slender, caespitose, decumbent to erect, no branching; nodes glabrous. Leaves membranaceus, mostly in basal portion. Leaf sheaths shorter than internodes, pilose at the margin, the younger papiloso-hirsute. Ligules ca. $1 \mathrm{~mm}$ long, ciliate. Blades 3.5-6(10) cm long, 2-3 mm wide, lanceolate, flat, widely acuminated, pilose on both surfaces, with long marginal tuberculous trichomes; base slightly broader than the sheath. Peduncles $6.5-10 \mathrm{~cm}$ long, terete, glabrous. Inflorescences mostly exserted; racemes single, erect, $3-6 \mathrm{~cm}$ long; raceme rachis ca. $0.2 \mathrm{~mm}$ wide, glabrous, ending in a meristematic apex; pedicels $1.5-2.0 \mathrm{~mm}$ long, glabrous. Spikelets solitary, 3.0-4.5 $\mathrm{mm}$ long, $0.8-1 \mathrm{~mm}$ wide, 2-seriated, compactly imbricated, dorsiventrally compressed, with trichomes around at base. Lower glumes 1.8-2.5 mm long, 0.4-0.7 mm wide, flat; apex acute, muticous; 5-nerved; membranaceos; pilose in the lower portion on the back, the trichomes reaching $2 \mathrm{~mm}$ long. Upper glumes 3.0-4.5 $\mathrm{mm}$ long, 0.7-1.0 mm wide; apex acuminated; 5-nerved; membranaceos; silky-pilose on the back following the nerves. Lower lemmas 2.5-3.1 mm long, 0.6-1 mm wide; 5-7-nerved; membranaceos; silky-pilose on the margins with a few thicker trichomes in the median portion. Lower paleas lacking. Upper florets $2-2.4 \mathrm{~mm}$ long, 0.5-1 mm wide; narrowly ellipsoid; glabrous; lodicules 2, minute; stamens 3, anthers ca. 1 mm long, purple. Caryopsis $1.2-1.5 \mathrm{~mm}$ long, $0.5 \mathrm{~mm}$ wide, elliptical, hilum linear.

Distribution and habitat:-Mesosetum sp.nov.1 is presently known from various localities in the territory of French Guiana, near the border with Amapá state, Brazil (Fig. 3). The new species occurs in inselbergs, on rocky savannas and humid areas, and grows on soils rich in organic matter. In the Neotropics, inselbergs are elevations with a special vegetation type and surrounded by rain forest (Sarthou \& Villiers 1998). 
Additional specimens examined (paratypes):-FRENCH GUIANA. Inselbergs du haut Marouini - A: Inselbergs de la D.Z., 02³6'30"N, 5401'45"W, alt. 220 m, 21 Jun 2004, J.J. de Granville \& F. Crozier 16271 (CAY!, P!, MO, US). Inselbergs de la haute Wanapi: zone du dôme central, 02 $31^{\prime} 00^{\prime \prime N}, 53^{\circ} 49^{\prime} 20^{\prime \prime} \mathrm{W}$, alt. 200 m, 14 Apr. 2004, J.J. de Granville, F. Crozier \& C. Sarthou 15916 (CAY!, P!). Inselbergs Roche-Dachine, 03² $28^{\prime} \mathrm{N}, 53^{\circ} 13^{\prime} \mathrm{W}$, alt. 200 m, 5 Apr. 1997, J.F. Villiers \& C. Sarthou 6042 (CAY!, P!). Frontière Guyane-Brésil, borne 4, 13 Apr. 1983, Feuillet 1005 (CAY!, P!).

Comments:-Among the species belonging to M. sect. Mesosetum, Mesosetum sp.nov.1 is more closely related to $M$. rottboellioides (Kunth 1815: 96) Hitchc. (1909: 211) and M. cayennense Steud. since all three species share the apex of pedicel oblique, spikelets ferrugineous, lower lemma with a few thicker trichomes in the median portion than the other trichomes of lower lemma, and upper floret up to $3.5 \mathrm{~mm}$ long. Therefore, only these species were included in Table 1.

Table 1 shows that Mesosetum sp.nov.1 can be distinguished from M. cayennense and M. rottboellioides by annual life form (versus perennial), racemes ending in a meristematic apex (versus racemes ending in a developed spikelet), longer pedicels 1.5-2.0 mm (versus 0.5-1.0 mm), and the pilosity of lower and upper glume.

\section{Acknowledgements}

This work was supported by Coordenação de Aperfeiçoamento de Pessoal de Nível Superior-CAPES (doctor grant to the first author), REFLORA Program (by grants to visit European Herbaria B, K and P) and Universidade de Brasília-UnB (laboratory facilities). We thank the curators and staff of CAY herbarium for exsiccate loans. 


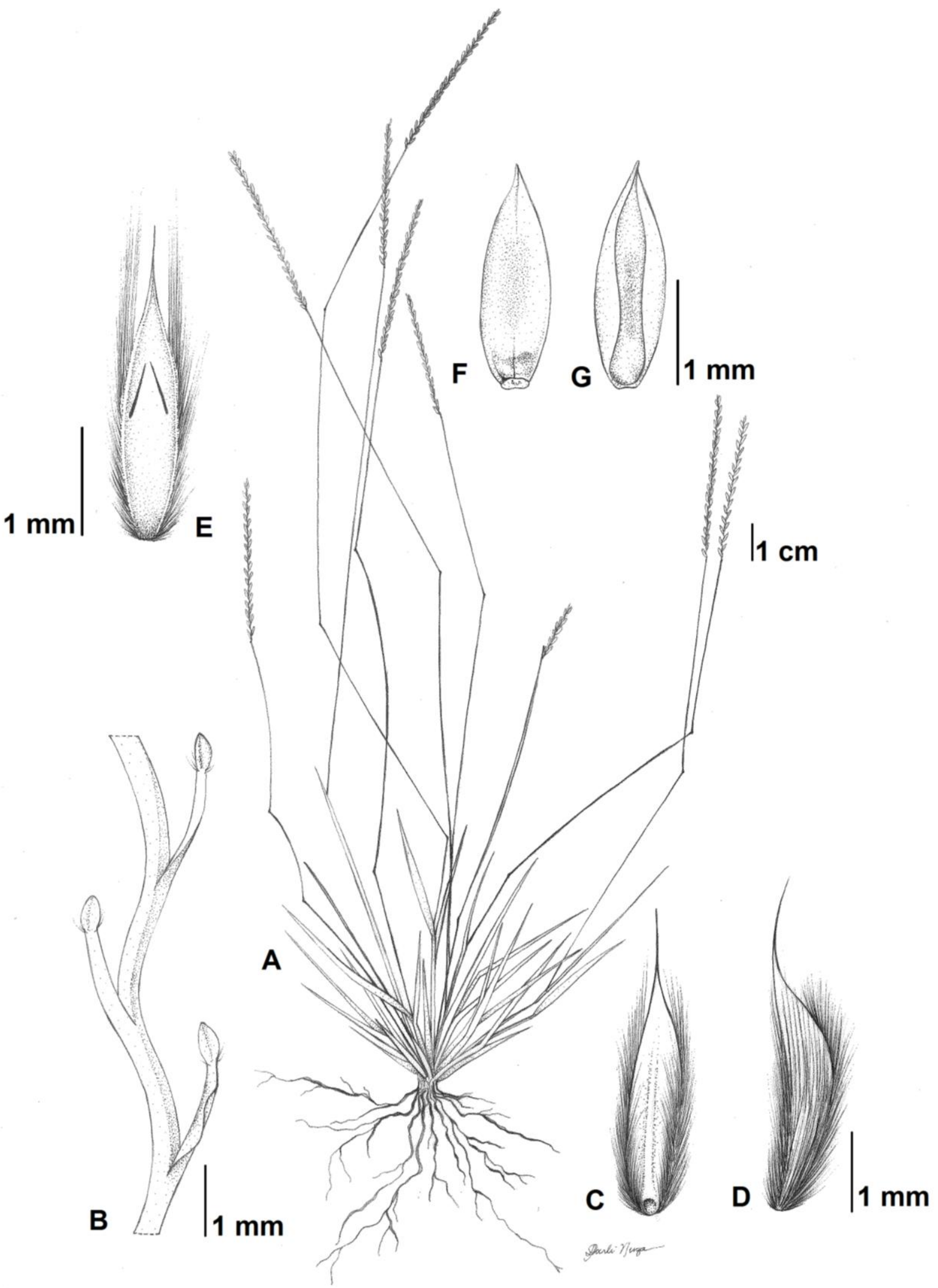

Figure 1. Mesosetum sp. nov. (A) habit; (B) detail of rachis and pedicel; (C) spikelet ventral view; (D) spikelet - lateral view; (E) detail of lower lemma - dorsal view; (F) upper anthecium - dorsal view; $(G)$ anthecium - ventral view. Drawn by Darli Nuza from holotype in CAY. 

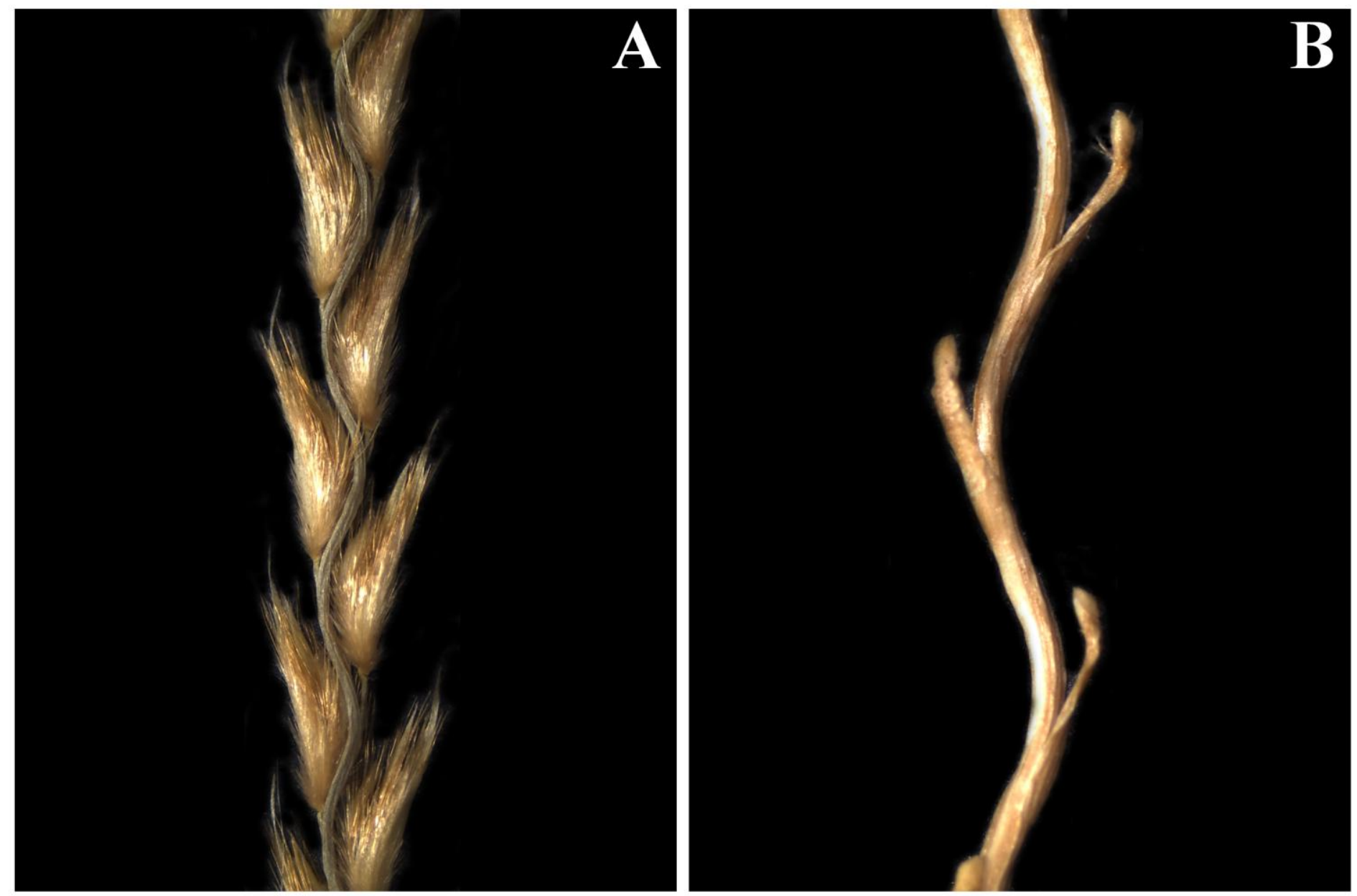

Figure 2. Photos of Mesosetum sp.nov.1, J.J. de Granville, L. Aliker \& C. Sarthou 15423 (CAY-paratype): (A) detail of inflorescence; (B) detail of rachis and pedicels. 


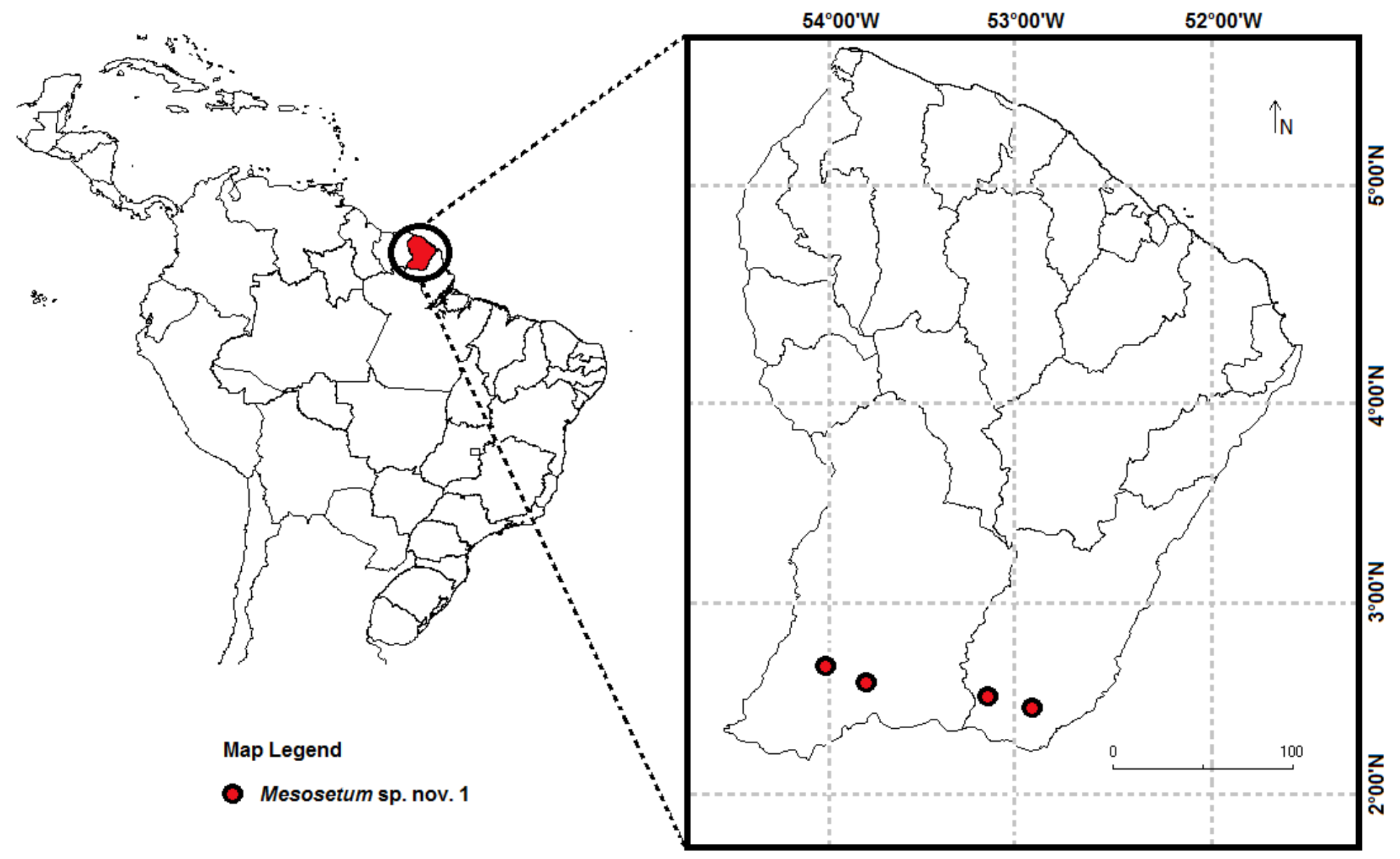

Figure 3. Distribution map of Mesosetum sp. nov. 1 in French Guiana. 
Table 1. Morphological differences between Mesosetum sp. nov. 1, M. cayennense and $M$. rottboellioides.

\begin{tabular}{|c|c|c|c|}
\hline & M. cayennense & M. rottboellioides & Mesosetum sp. nov.1 \\
\hline Life form & perennial & perennial & annual \\
\hline $\begin{array}{c}\text { Distribution of leaves } \\
\text { on the culm }\end{array}$ & mostly cauline & mostly basal & mostly cauline \\
\hline Racemes & $\begin{array}{c}\text { 5-18 mm long., } \\
\text { ending in a } \\
\text { developed spikelet }\end{array}$ & $\begin{array}{c}\text { 5-13 mm long., } \\
\text { ending in a developed } \\
\text { spikelet }\end{array}$ & $\begin{array}{c}\text { 3-6 mm long., } \\
\text { ending in a aborted } \\
\text { spikelet }\end{array}$ \\
\hline Pedicels & $0.7-1.0 \mathrm{~mm}$ long. & $0.5-1.0 \mathrm{~mm}$ long. & $1.5-2.0 \mathrm{~mm}$ long. \\
\hline Lower glume & $\begin{array}{l}\text { 2.8-3.1 mm long., } \\
\text { apex truncate, } \\
\text { two tuffs of } \\
\text { trichomes on the } \\
\text { median portion }\end{array}$ & $\begin{array}{l}\text { 2.8-3.5 mm long., } \\
\text { apex rounded to acute, } \\
\text { trichomes following only } \\
\text { the marginal nerves }\end{array}$ & $\begin{array}{l}\text { 1.8-2.5 mm long., } \\
\text { apex rounded to acute, } \\
\text { trichomes following the } \\
\text { marginal nerves }\end{array}$ \\
\hline Upper glume & $\begin{array}{l}\text { apex acute or } 2- \\
\text { dentate, } \\
\text { two tuffs of hairs on } \\
\text { the distal portion }\end{array}$ & $\begin{array}{l}\text { apex acuminate, } \\
\text { trichomes uniformly } \\
\text { distributed on the back }\end{array}$ & $\begin{array}{l}\text { apex acuminate, } \\
\text { trichomes uniformly } \\
\text { distributed on the back }\end{array}$ \\
\hline Lower lemma & $\begin{array}{l}\text { 3.8-4.0 mm long., } \\
\text { 3-nerved }\end{array}$ & $\begin{array}{c}\text { 3.5-4.0 mm long., } \\
\text { 3-nerved }\end{array}$ & $\begin{array}{l}\text { 2.5-3.1 mm long., } \\
\text { 5-nerved }\end{array}$ \\
\hline Upper floret & $3.0 \mathrm{~mm}$ long. & $3.2 \mathrm{~mm}$ long. & $2.0-2.4 \mathrm{~mm}$ long. \\
\hline
\end{tabular}




\section{References}

Filgueiras, T.S. (1989) Revisão de Mesosetum Steudel (Gramineae: Paniceae). Acta Amazônica 19: $47-114$.

Funk, V., Hollowell, T., Berry, P., Kelloff, C. \& Alexander, S.N. (2007) Checklist of the Plants of the Guiana Shield (VENEZUELA: Amazonas, Bolivar, Delta Amacuro; GUYANA, SURINAM, FRENCH GUIANA). Contributions from the United States National Herbarium 55: 1-584.

Hitchcock, A.S. (1909) The grasses of Cuba. Contributions from the United States National Herbarium 12 (6): 1-474.

Kunth, C.S. (1815) Gramineae. In: Humboldt, A., Bonpland, A. \& Kunth, K. (Eds.) Nova genera et species plantarum (quarto ed.) 1. Lutetiae Parisiorum: sumtibus librariae Graeco-LatiniGermanicae, pp. 84-201.

Morrone, O., Aagesen, L., Scataglini, M.A., Salariato, D.L., Denham, S., Chemisquy, M.A., Sede, S.M., Giussani, L.M., Kellogg, E.A. \& Zuloaga, F.O. (2012) Phylogeny of the Paniceae (Poaceae: Panicoideae): integrating plastid DNA sequences and morphology into a new classification. Cladistics $1-24$.

Presl, J.S. (1830) Gramineae. In: Presl, K.B. (Ed.) Reliquiae Haenkeanae seu descriptiones et icones plantarum, quas in America meridionali et boreali, in insulis Philippinis et Marianis collegit Thaddeus Haenke, rede-git et in ordinem digessit Carolus Bor. Presl 1(4/5). J.G. Galve, Prague, pp. 207-355.

Sarthou, C. \& Villiers, J.F. (1998) Epilithic plant communities on inselbergs in French Guiana. Journal of Vegetation Science 9: 847-860.

Soreng, R.J., Peterson, P.M., Romaschenko, K., Davidse, G., Zuloaga, F.O., Judziewicz, E.J., Filgueiras, T.S., Davis, J.I. \& Morrone, O. (2015) A worldwide phylogenetic classification of the Poaceae (Gramineae). Journal of Systematics and Evolution 53: 117-137. 
Steudel, E.G. von (1854) Gramineae. Synopsis Plantarum Glumacearum 1. J. B. Metzler, Stuttgartle, $474 \mathrm{pp}$. 
Capítulo 4

Micromorphology of the upper anthecium in Mesosetum Steud. and related genera (Poaceae, Arthropogoninae) and its taxonomic applications

Artigo publicado no periódico Rodriguésia 66(2): 645-657. 2015

http://rodriguesia.jbrj.gov.br

DOI: $10.1590 / 2175-7860201566227$ 


\title{
Micromorphology of the upper anthecium in Mesosetum Steud. and related genera (Poaceae, Arthropogoninae) and its taxonomic applications
}

\author{
Anádria Stéphanie da Silva ${ }^{1,3}$, André Rodolfo de Oliveira Ribeiro ${ }^{1}$, Mayco Werllen dos Santos Sousa ${ }^{1}$, \\ Christopher William Fagg ${ }^{1}$, Rosana Falcão ${ }^{2}$ \& Regina Célia de Oliveira ${ }^{1}$
}

\begin{abstract}
Mesosetum is a Neotropical genus with 25 species, and 21 of them occur in Brazil. Mesosetum forms a clade closely related with Keratochlaena rigidifolia and Tatianyx arnacites. The objective of this work was to establish the taxonomic value of the upper anthecium micromorphology for the group. A total of 96 specimens, representing all Mesosetum species (except M. wrightii), K. rigidifolia and T. arnacites were examined under a scanning electron microscope (SEM). PCA and UPGMA analysis were applied using the micromorphological characters. Fifithteen useful taxonomic characters were identified. We highlight the following characters to distinguish the Mesosetum species: the presence, type and distribution of papillae on the abaxial surface of the upper lemma; the presence of unicellular macrohairs and bicellular microhairs; presence or absence of silica cells and the structure of the germination lid. The present work shows that the micromorphological characters identified are important taxonomically at the specific level, allowing the species identification in many cases. Key words: Grass, Keratochlaena, Tatianyx, PCA, UPGMA.
\end{abstract}

\section{Introduction}

Mesosetum Steud. belongs to the subfamily Panicoideae, tribe Paspaleae. It is inserted in the subtribe Arthropogoninae, along with 15 other American genera (Morrone et al. 2012). Within Arthropogoninae, Mesosetum forms a clade with Tatianyx Zuloaga \& Soderstr. and Keratochlaena Morrone genera, as observed in many phylogenies (Giussani et al. 2001; Aliscioni et al. 2003; GPWG 2011; Morrone et al. 2012).

Swallen (1937) proposed 33 binomials for Mesosetum, but only 25 were recognized as valid taxa by Filgueiras (1989). The genus has a predominantly Neotropical distribution, and Brazil is the centre of diversity with 21 species, being 12 endemic to the country (Filgueiras et al. 2014). Most of these species occur in Central Brazil, where a total of 16 species occur, being seven endemic to this region (Filgueiras et al. 2014).

Mesosetum is characterized by raceme-like solitary terminal inflorescence, spikelets with the first glume adaxial to rachis, glume and lower lemma with tuffs of hairs and caryopsis with linear hilum (Filgueiras 1986, 1989). All these characters are homoplastic because they occur in other genera of the tribe.

There is controversy in the infrageneric classification of the genus Mesosetum. Chase (1911) was the first to establish a morphological delimitation of the genus and proposed two sections: Mesosetum sect. Mesosetum and M. sect. Bifaria (Hack.) Chase. Swallen (1937) revised the genus and recognized 33 species and added four new sections to those proposed by Chase (1911): M. sect. Annua Swallen, M. sect. Penicillata Swallen, $M$. sect. Loliiformia Swallen, $M$. sect. Schlerochloae Swallen and M. sect. Fulva Swallen (latter equivalent to $M$. sect. Mesosetum). Pilger (1940) partially accepted the work of Swallen, recognizing 30 species and only three sections: $M$. sect. Bifaria, M. sect. Eumesosetum Pilg. and M. sect. Schlerochloae. Filgueiras (1986,

\footnotetext{
${ }^{1}$ Universidade de Brasília, Inst. Ciências Biológicas, Programa de Pós-Graduação em Botânica, C.P. 04457, 70910-970, Brasília, DF, Brasil

${ }^{2}$ Embrapa Recursos Genéticos e Biotecnologia, Parque Estação Biológica, Av. W5 Norte (final), C.P. 02372, 70770-900 Brasilia, DF, Brasil.

${ }^{3}$ Author for correspondence: anadriastephanies@hotmail.com
} 
1989) recognized 25 species distributed in five sections. This author included $M$. sect. Annua in $M$. sect. Loliiformia, and transferred M. sect. Fulva (containing the type species of the genus) to $M$. sect. Mesosetum.

Investigations on the ornamentation of the upper anthecium has revealed important taxonomic information in the Panicoideae (Mejia-Saules \& Bisby 2003; Giraldo-Cañas 2004), specially in the delimitation of genera and species phylogenetically related to Mesosetum, e.g. Apochloa Zuloaga \& Morrone, Canastra aristella (Döll) Zuloaga \& Morrone (under Panicum aristellum Döll), Cyphonanthus Zuloaga \& Morrone, Homolepis Chase, Keratochlaena (under Sclerochlamys, nom. illeg.), Oncorachis Morrone \& Zuloaga, Stephostachys Zuloaga \& Morrone, Streptostachys Desv., and Tatianyx (Zuloaga \& Sordestrom 1985, Morrone \& Zuloaga 1991; Morrone et al. 2007; Sede et al. 2008, 2009; Zuloaga et al. 2010). Nevertheless, there are no studies on the upper anthecium ornamentation using scanning electron microscopy (SEM) in Mesosetum species.

While Mesosetum is apparently well circumscribed from the taxonomic and nomenclatural viewpoint, the identification of specimens is difficult. The identification keys and descriptions of many species are based on a small number of specimens available at the time of the last two revisions (Swallen 1937; Filgueiras 1989), which does not represent the range of the morphological variability of the taxa. The present work analyses the upper anthecium micromorphological characters using SEM in Mesosetum and related species to verify their taxonomic value, if these characters support the consistency of the Mesosetum sections proposed by Filgueiras (1989), and if there are common character states between the clade MesosetumTatianyx-Keratochlaena.

\section{Materials and Methods}

This work is based on the upper anthecium micromorphology of 24 Mesosetum species, with a total of 93 specimens analyzed, plus one of Keratochlaena rigidifolia (Filg., Morrone \& Zuloaga) Morrone \& Zuloaga and two of Tatianyx arnacites (Trin.) Zuloaga \& Soderstr. The samples were obtained from herbarium specimens. The specimens examined are listed in Table 1 and the herbaria acronyms are according to Thiers (2014, continuously updated). The dataset included all the Mesosetum species except $M$. wrightii Hitchc., endemic to Cuba, which had very limited collections available, and two other related genera: Tatianyx and Keratochlaena.

The mature anthecia were mounted onto aluminum metal stubs using carbon double-stick tape and sputter-coated with platinum without pretreatment. The material was carried out on SEM (Jeol JSM 7001S) at $15 \mathrm{KV}$, at the Electronic Microscope Laboratories of the University of Brasilia, and "Embrapa Recursos Genéticos e Biotecnologia". Deformed and flaccid immature anthecia were not considered. The terminology followed Ellis (1979), Sordestrom \& Zuloaga (1989) and Giraldo-Cañas (2004).

Table 2 shows the descriptors used in the present work. Significant differences were not found between the lemma and palea, which presented similar ornamentation.

Each specimen measured was considered an operational taxonomic unit (OTU), following (Rohlf 2000). Cluster analysis was carried out to analyze the taxonomic value of the micromorphological characters in the genus. The similarity matrix was based on Jaccard's coefficient and then unweighted pair group method with arithmetic averages (UPGMA) applied in the dendrogram. A cophenetic matrix was computed from the clustering matrix in order to assess the correlation between the matrix of similarity and the dendrogram. Principal component analysis (PCA) was used based on the correlation matrix (Tab. 3). All these analyses were undertaken using the software NTSYS-PC 2.0 (Rohlf 2000).

\section{Results}

Micromorphology Characterization

Our results are new to Mesosetum species. The anthecia can be elliptic, lanceolate or ovate (M. pappophorum (Nees) Kuhlm.) and the apex acute to acuminate ( $M$. sect Sclerochloae). The anthecia vary from glabrous to hairy, with bicellular microhair and unicellular macrohair short or long. The surface of anthecia is quite variable, can be totally smooth (M. pappophorum) to completely covered by papillae and silica cells. The epidermal cells vary into shape and size. Stomata (Fig. 1a) were seen in 16 species, however difficulties in the technique could hide their presence in the other species, hence they were not analyzed.

Simple and compound papillae (Fig. 1a,c,e-g) were found on short and long cells, generally with 
Table 1 - Specimens examined for micromorphological characters from upper anthecium. * According to Filgueiras (1989).

\begin{tabular}{|c|c|c|c|c|}
\hline Species & Section* & Collection Site & Voucher & Herbarium \\
\hline Mesosetum agropyroides $\mathrm{Mez}$ & Penicillata & s.l. - GO & Glaziou s.n. & $\mathrm{K}$ \\
\hline \multirow[t]{3}{*}{ Mesosetum alatum Filg. } & Bifaria & Água Boa - MT & R.C. Oliveira et al. 2765 & UB \\
\hline & & Novo Santo Antonio - MT & H. Jancoski et al. 444 & UB \\
\hline & & Xavantina - MT & H.S. Irwin et al. 16467 & UB \\
\hline \multirow[t]{3}{*}{ Mesosetum annuum Swallen } & Loliiformia & Flores de Goiás - GO & A.S. Silva et al. 269 & UB \\
\hline & & Jerumenha - PI & A.S. Silva et al. 270 & UB \\
\hline & & Campo Maior - PI & M.S.B. Nascimento 103 & $\mathrm{~K}$ \\
\hline Mesosetum ansatum (Trin.) Kuhlm. & Bifaria & Poconé - MT & R.C. Oliveira et al. 2766 & UB \\
\hline \multirow[t]{3}{*}{ Mesosetum arenarium Swallen } & Loliiformia & Diamantina - MG & T.S. Filgueiras et al. 11321 & IBGE \\
\hline & & Diamantina - MG & T.S. Filgueiras et al. 1101 & IBGE \\
\hline & & Cristalina - GO & H.S. Irwin et al. 13337 & IBGE \\
\hline Mesosetum bifarium (Hack.) Chase & Bifaria & Teresina de Goiás - GO & A.S. Silva et al. 235 & UB \\
\hline Mesosetum blakei Swallen & Penicillata & Zelaya, Nicarágua & W.D. Stevens $8188-a$ & $\mathrm{~K}$ \\
\hline \multirow[t]{12}{*}{ Mesosetum cayennense Steud. } & Mesosetum & Alto Paraíso - GO & R.C. Oliveira et al. 2744 & UB \\
\hline & & Cachoeira Paraíso - TO & R.C. Oliveira et al. 2848 & UB \\
\hline & & Mineiros - MT & G.H. Rua 940 & UB \\
\hline & & La Paz, Bolívia & R. Haase 630 & $\mathrm{~K}$ \\
\hline & & La Paz, Bolívia & C.E. White 2318 & $\mathrm{~K}$ \\
\hline & & Santa Cruz, Bolívia & B. Bruderreck 70 & $\mathrm{~K}$ \\
\hline & & Santa Cruz, Bolívia & J.R.I. Wood et al. 20791 & $\mathrm{~K}$ \\
\hline & & Santa Cruz, Bolívia & J.R.I. Wood et al. 20006 & K \\
\hline & & Santa Cruz, Bolivia & J.R.I. Wood et al. 17248 & $\mathrm{~K}$ \\
\hline & & Santa Cruz, Bolívia & J.R.I. Wood et al. 25982 & $\mathrm{~K}$ \\
\hline & & Santa Cruz, Bolívia & J.R.I. Wood et al. 13516 & $\mathrm{~K}$ \\
\hline & & Santa Cruz, Bolívia & J.R.I. Wood et al. 26130 & $\mathrm{~K}$ \\
\hline \multirow[t]{8}{*}{ Mesosetum chaseae Luces } & Bifaria & Poconé - MT & R.C. Oliveira et al. 2772 & UB \\
\hline & & Corumbá - MS & A. Allem et al. 1152 & CEN \\
\hline & & Corumbá - MS & A. Allem et al. 1397 & CEN \\
\hline & & Corumbá - MS & A. Pott et al 1771 & CEN \\
\hline & & Furnas - MG & S.C. Pereira et al. 7178 & IBGE \\
\hline & & Boa Vista - RR & L. Coradin et al. 871 & CEN \\
\hline & & Boa Vista - RR & L. Coradin et al. 909 & CEN \\
\hline & & Bolivar, Venezuela & G. Davidse 22876 & $\mathrm{~K}$ \\
\hline \multirow{3}{*}{$\begin{array}{l}\text { Mesosetum chlorostachyum (Döll) } \\
\text { Chase }\end{array}$} & Loliiformia & Rio Negro - AM & Spruce 1310 & $\mathrm{~K}$ \\
\hline & & Rio Negro - AM & Spruce s.n. & $\mathrm{K}$ \\
\hline & & Atabapo, Venezuela & G. Davidse 16863 & ESA \\
\hline
\end{tabular}




\begin{tabular}{|c|c|c|c|c|}
\hline Species & Section* & Collection Site & Voucher & Herbarium \\
\hline \multirow[t]{3}{*}{ Mesosetum comatum Swallen } & Loliiformia & Missiones, Argentina & M. Crovetto 8241 & BAA \\
\hline & & Missiones, Argentina & M. Crovetto 9533 & BAA \\
\hline & & Missiones, Argentina & M.E. Mulgura 3461 & BAA \\
\hline \multirow[t]{4}{*}{ Mesosetum compressum Swallen } & Bifaria & Pesqueira - PE & D. Andrade-Lima et al. 9438 & UB \\
\hline & & Brejo da Madre de Deus - PE & L.M. Nascimento et al. 393 & HUEFS \\
\hline & & Estreito, Marabá - PA & G.S. Pinheiro et al. 68 & IAN \\
\hline & & Estreito, Marabá - PA & G.S. Pinheiro et al. 495 & IAN \\
\hline \multirow{3}{*}{$\begin{array}{l}\text { Mesosetum elytrochaetum (Hack.) } \\
\text { Swallen }\end{array}$} & Bifaria & Alto Paraíso - GO & R. C. Oliveira et al. 2722 & UB \\
\hline & & Alto Paraíso - GO & H.M. Longhi-Wagner 3934 & IBGE \\
\hline & & Teresina de Goiás - GO & T. S. Filgueiras et al. 3229 & SP \\
\hline \multirow[t]{3}{*}{ Mesosetum exaratum (Trin.) Chase } & Penicillata & Jaguariaíva - PR & J.F.M. Valls et al. 11260 & CEN \\
\hline & & Jaboticatubas - MG & T. Sendulski 443 & CEN \\
\hline & & São José do Barreiro - SP & L. Freitas 753 & CEN \\
\hline Mesosetum ferrugineum (Trin.) Chase & Mesosetum & São João del Rei - MG & Glaziou 17385 & $\mathrm{P}$ \\
\hline \multirow[t]{4}{*}{ Mesosetum filifolium F.T. Hubb. } & Penicillata & Parauapebas, Pará & C.R. Martins 998 & UB \\
\hline & & Atabapo, Venezuela & G. Davidse et al. 17209 & $\mathrm{~K}$ \\
\hline & & Trinidad, Belize & G. Davidse et al. 32780 & $\mathrm{~K}$ \\
\hline & & San Luis, Honduras & R.R. Innes 19 & $\mathrm{~K}$ \\
\hline \multirow{4}{*}{$\begin{array}{l}\text { Mesosetum gibbosum Renvoize } \\
\text { \& Filg. }\end{array}$} & Loliiformia & Rio de Contas - BA & S. Atkins et al. 14783 & ESA \\
\hline & & Lençóis - BA & J.R. Pirani et al. 7238 & $\mathrm{~K}$ \\
\hline & & Abaíra - BA & R.M. Harley et al. 50772 & $\mathrm{~K}$ \\
\hline & & Palmeiras - BA & V.C. Souza et al. 5238 & $\mathrm{~K}$ \\
\hline \multirow{5}{*}{$\begin{array}{l}\text { Mesosetum loliiforme (Hochst. ex } \\
\text { Steud.) Chase }\end{array}$} & Loliiformia & Niquelândia - GO & A.S. Silva et al. 247 & UB \\
\hline & & Brasília - DF & M.W.S. Souza 62 & UB \\
\hline & & St. Ignatius, Guiana & R. Goodland 226 & $\mathrm{~K}$ \\
\hline & & Pakaraima, Guiana & T.W. Henkel 5820 & $\mathrm{~K}$ \\
\hline & & Kayserberg, Suriname & K.U. Kramer et al. 3003 & $\mathrm{~K}$ \\
\hline \multirow[t]{3}{*}{ Mesosetum longiaristatum Filg. } & Bifaria & Teresina de Goiás - GO & R.C. Oliveira et al. 2816 & UB \\
\hline & & São Domingos - GO & J.F.M. Valls et al. 15812 & CEN \\
\hline & & São Domingos - GO & J.F.M. Valls et al. 15841 & CEN \\
\hline \multirow{5}{*}{$\begin{array}{l}\text { Mesosetum pappophorum (Nees) } \\
\text { Kuhlm. }\end{array}$} & Loliiformia & Flores de Goiás - GO & A.S. Silva et al. 267 & UB \\
\hline & & Flores de Goiás - GO & J.F.M. Valls et al. 15949 & CEN \\
\hline & & Flores de Goiás - GO & J.F.M. Valls et al. 15953 & CEN \\
\hline & & Serra Negra do Norte - RN & M.F. Simon 498 & HUEFS \\
\hline & & Serra Negra do Norte - RN & C.G.T. Ferreira 254 & UFRN \\
\hline \multirow[t]{4}{*}{ Mesosetum penicillatum $\mathrm{Mez}$} & Penicillata & Xavantina - MT & G. Eiten \& L.T. Eiten 8541 & $\mathrm{~K}$ \\
\hline & & Xavantina - MT & G.D. Smith 81 & $\mathrm{~K}$ \\
\hline & & Beni, Bolívia & G. Beck 20682 & $\mathrm{~K}$ \\
\hline & & La Paz, Bolívia & R. Haase 122 & $\mathrm{~K}$ \\
\hline Mesosetum pittieri Hitchc. & Sclerochloae & Chepo, Panamá & H. Pittier 4516 & $\mathrm{~K}$ \\
\hline
\end{tabular}




\begin{tabular}{|c|c|c|c|c|}
\hline Species & Section* & Collection Site & Voucher & Herbarium \\
\hline \multirow{13}{*}{$\begin{array}{l}\text { Mesosetum rottboellioides (Kunth) } \\
\text { Hitchc. }\end{array}$} & \multirow[t]{13}{*}{ Mesosetum } & Grão Mogol - MG & P.A. Reis et al. 331 & UB \\
\hline & & Cristália - MG & Hatschbach 55064 & ICN \\
\hline & & Buíque - PE & D.N. Silva et al. 36 & UB \\
\hline & & Serra Branca - PB & M.C. Pesssoa et al. 477 & UB \\
\hline & & Atures, Venezuela & G. Davidse 15250 & $\mathrm{~K}$ \\
\hline & & Atures, Venezuela & G. Davidse 15428 & $\mathrm{~K}$ \\
\hline & & Atures, Venezuela & O. Hubber 2335 & $\mathrm{~K}$ \\
\hline & & Atures, Venezuela & O. Hubber 5207 & $\mathrm{~K}$ \\
\hline & & Atures, Venezuela & O. Hubber 5259 & $\mathrm{~K}$ \\
\hline & & Atabapo, Venezuela & J.J. Wurdack 43753 & $\mathrm{~K}$ \\
\hline & & Bolivar, Venezuela & J.J. Wurdack 39762 & $\mathrm{~K}$ \\
\hline & & Piar, Venezuela & O. Hubber 12154 & $\mathrm{~K}$ \\
\hline & & Santa Barbara, Venezuela & M.J. Eden 224 & $\mathrm{~K}$ \\
\hline \multirow{4}{*}{$\begin{array}{l}\text { Mesosetum sclerochloa (Trin.) } \\
\text { Hitchc. }\end{array}$} & \multirow{4}{*}{ Sclerochloae } & Flores de Goiás - GO & A.S. Silva et al. 266 & UB \\
\hline & & Flores de Goiás - GO & J.F.M. Valls et al. 15937 & CEN \\
\hline & & Flores de Goiás - GO & J.F.M. Valls et al. 15947 & CEN \\
\hline & & Flores de Goiás - GO & J.F.M. Valls et al. 15954 & CEN \\
\hline $\begin{array}{l}\text { Keratochlaena rigidifolia (Filg., } \\
\text { Morrone \& Zuloaga) Morrone \& } \\
\text { Zuloaga }\end{array}$ & - & Loreto - MA & J.F.M. Valls et al. 8432 & CEN \\
\hline \multirow{2}{*}{$\begin{array}{l}\text { Tatianyx arnacites (Trin.) Zuloaga } \\
\& \text { Soderstr. }\end{array}$} & - & Abaíra - BA & W. Ganev 2728 & $\mathrm{~K}$ \\
\hline & & Guiratinga - MT & S.S. Silva 133 & IBGE \\
\hline
\end{tabular}

1-3 papillae per cell. In M. loliiforme (Hochst. ex Steud.) Chase, M. annuum Swallen, $M$. arenarium Swallen, M. chlorostachyum (Döll) Chase, M. chaseae Luces, and $M$. ansatum (Trin.) Kuhlm., coalescence between the larger papillae occurs in the basal and distal portions of the anthecium, forming cells with two to six coalescent papillae (Fig. 1e, g).

The silica cells were found in the cross form (Fig. 1b). They were registered in $M$. alatum Filg., M. bifarium (Hack.) Chase, M. compressum Swallen, M. elytrochaetum (Hack.) Swallen, M. exaratum (Trin.) Chase, M. longiaristatum Filg., M. blakei Swallen, and M. filifolium F.T. Hubb.

The germination lid in the anthecium basal portion is very conspicuous in all species, and differences were observed in these structures (Fig. 1h, i). We identified two new character states. Unilobed germination lid is present in Mesosetum alatum (Fig. 1h), M. agropyroides
Mez, M. chlorostachyum, M. ferrugineum (Trin.) Chase, M. filifolium, M. gibbosum Renvoize \& Filg., and M. pappophorum. This is the typical form found in Paniceae (Rost \& Simper 1975; Johnston \& Watson 1981; Giraldo-Cañas 2004), but bilobed germination lid was observed in the other 17 species (e.g. M. elytrochaetum, Fig. 1i).

In the third distal portion, the presence or absence of long macrohairs aided in the distinction of the Mesosetum species. Only five species analyzed did not show a conspicuous hairy anthecium apex. This character contributed to distinguish $M$. exaratum from $M$. filifolium .

Bicellular microhairs were found in $M$. cayennense Steud., M. rottboellioides (Kunth) Hitchc., M. filifolium and M. sect. Bifaria. Only the panicoid type was registered (Zuloaga \& Soderstrom 1985), with the basal cell smaller than the lanceolate apical cell with an acute apex (Fig. 1d, arrow). 
Table 2 - Micromorphological characters and character states of the upper anthecium of Mesosetum, Keratochlaena, and Tatianyx species used in the PCA and UPGMA analyses.

1. Papilla on the abaxial surface: absent( 0$)$, present(1)

2. Papilla on the germination lid surface: absent(0), present(1)

3. Papilla on the median surface: absent $(0)$, present(1)

4. Papilla on the distal surface: absent( 0$)$, present(1)

5. Simple papilla: absent $(0)$, present(1)

6. Compound papilla: absent(0), present(1)

7. Number of papilla per epidermical cell: one per cell(0), more than one per cell(1)

8. Coalescence between the larger papillas: absent(0), present(1)

9. Bicellular microhairs: absent $(0)$, present(1)

10 Unicellular macrohairs: absent(0), present(1)

11. Unicellular macrohairs on the median surface: absent(0), present(1)

12. Unicellular macrohairs on the distal surface: absent(0), present(1)

13. Cruciform silica cells: absent(0), present(1)

14. Germination lid: bilobed(0), unilobed(1)

15. Germination lid lobe width/dorsal spikelet width: narrow(0), equal(1)

Table 3 - Data matrix used in the cluster analysis of Mesosetum and related genera. Character states according to Table 2

\begin{tabular}{|c|c|c|c|c|c|c|c|c|c|c|c|c|c|c|c|}
\hline Species/ Character states & 1 & 2 & 3 & 4 & 5 & 6 & 7 & 8 & 9 & 10 & 11 & 12 & 13 & 14 & 15 \\
\hline Mesosetum agropyroides $\mathrm{Mez}$ & 1 & 0 & 1 & 1 & 1 & 1 & 1 & 0 & 0 & 1 & 0 & 1 & 0 & 1 & 0 \\
\hline Mesosetum alatum Filg. & 1 & 0 & 0 & 1 & 1 & 0 & 0 & 0 & 1 & 1 & 1 & 1 & 1 & 1 & 1 \\
\hline Mesosetum annuum Swallen & 1 & 1 & 1 & 1 & 1 & 1 & 1 & 1 & 0 & 0 & 0 & 0 & 0 & 0 & 0 \\
\hline Mesosetum ansatum (Trin.) Kuhlm. & 1 & 0 & 0 & 1 & 1 & 1 & 1 & 1 & 1 & 1 & 0 & 1 & 0 & 0 & 0 \\
\hline Mesosetum arenarium Swallen & 1 & 1 & 1 & 1 & 1 & 1 & 1 & 1 & 0 & 1 & 0 & 1 & 0 & 0 & 0 \\
\hline Mesosetum bifarium (Hack.) Chase & 1 & 0 & 0 & 1 & 1 & 0 & 1 & 0 & 1 & 1 & 1 & 1 & 1 & 0 & 0 \\
\hline Mesosetum blakei Swallen & 1 & 1 & 1 & 1 & 1 & 0 & 1 & 0 & 0 & 1 & 0 & 1 & 1 & 0 & 1 \\
\hline Mesosetum cayennense Steud. & 1 & 1 & 1 & 1 & 0 & 1 & 0 & 0 & 1 & 1 & 1 & 1 & 0 & 0 & 0 \\
\hline Mesosetum chaseae Luces & 1 & 0 & 1 & 1 & 1 & 1 & 1 & 1 & 1 & 1 & 0 & 1 & 0 & 0 & 0 \\
\hline Mesosetum chlorostachyum (Döll) Chase & 1 & 1 & 1 & 1 & 1 & 1 & 1 & 1 & 0 & 0 & 0 & 0 & 0 & 0 & 0 \\
\hline Mesosetum compressum Swallen & 1 & 0 & 0 & 0 & 1 & 0 & 0 & 0 & 1 & 1 & 1 & 1 & 1 & 0 & 0 \\
\hline $\begin{array}{l}\text { Mesosetum elytrochaetum (Hack.) } \\
\text { Swallen }\end{array}$ & 1 & 0 & 0 & 1 & 1 & 1 & 1 & 0 & 1 & 1 & 1 & 1 & 1 & 0 & 0 \\
\hline Mesosetum exaratum (Trin.) Chase & 0 & 0 & 0 & 0 & 0 & 0 & 0 & 0 & 0 & 0 & 0 & 0 & 0 & 1 & 1 \\
\hline Mesosetum ferrugineum (Trin.) Chase & 1 & 1 & 1 & 1 & 0 & 1 & 0 & 0 & 1 & 1 & 1 & 1 & 0 & 1 & 1 \\
\hline Mesosetum filifolium F.T. Hubb. & 0 & 0 & 0 & 0 & 0 & 0 & 0 & 0 & 1 & 0 & 0 & 1 & 1 & 1 & 0 \\
\hline Mesosetum gibbosum Renvoize \& Filg. & 1 & 0 & 1 & 1 & 1 & 1 & 1 & 0 & 0 & 1 & 0 & 1 & 0 & 1 & 1 \\
\hline $\begin{array}{l}\text { Mesosetum loliiforme (Hochst. ex } \\
\text { Steud.) Chase }\end{array}$ & 1 & 1 & 1 & 1 & 1 & 1 & 1 & 1 & 0 & 0 & 0 & 0 & 0 & 0 & 0 \\
\hline Mesosetum longiaristatum Filg. & 1 & 0 & 0 & 1 & 1 & 1 & 1 & 0 & 1 & 1 & 1 & 1 & 1 & 0 & 0 \\
\hline Mesosetum pappophorum (Nees) Kuhlm. & 0 & 0 & 0 & 0 & 0 & 0 & 0 & 0 & 0 & 0 & 0 & 0 & 0 & 1 & 1 \\
\hline Mesosetum penicillatum $\mathrm{Mez}$ & 1 & 1 & 1 & 1 & 0 & 1 & 0 & 0 & 0 & 1 & 0 & 1 & 0 & 1 & 0 \\
\hline Mesosetum pittieri Hitchc. & 1 & 1 & 1 & 1 & 1 & 1 & 0 & 0 & 0 & 1 & 0 & 1 & 0 & 1 & 0 \\
\hline
\end{tabular}




\begin{tabular}{|c|c|c|c|c|c|c|c|c|c|c|c|c|c|c|c|}
\hline Species/ Character states & 1 & 2 & 3 & 4 & 5 & 6 & 7 & 8 & 9 & 10 & 11 & 12 & 13 & 14 & 15 \\
\hline $\begin{array}{l}\text { Mesosetum rottboellioides (Kunth) } \\
\text { Hitchc. }\end{array}$ & 1 & 1 & 1 & 1 & 0 & 1 & 0 & 0 & 1 & 1 & 1 & 1 & 0 & 0 & 0 \\
\hline Mesosetum sclerochloa (Trin.) Hitchc. & 1 & 1 & 1 & 1 & 1 & 1 & 0 & 0 & 0 & 1 & 0 & 1 & 0 & 1 & 0 \\
\hline Mesosetum comatum Swallen & 1 & 1 & 1 & 1 & 1 & 1 & 1 & 1 & 0 & 0 & 0 & 0 & 0 & 0 & 0 \\
\hline $\begin{array}{l}\text { Keratochlaena rigidifolia (Filg., } \\
\text { Morrone \& Zuloaga) Morrone \& Zuloaga }\end{array}$ & 1 & 1 & 1 & 1 & 0 & 1 & 0 & 0 & 0 & 0 & 0 & 1 & 0 & 0 & 0 \\
\hline $\begin{array}{l}\text { Tatianyx arnacites (Trin.) Zuloaga \& } \\
\text { Soderstr. }\end{array}$ & 1 & 0 & 1 & 1 & 1 & 1 & 1 & 0 & 0 & 0 & 0 & 0 & 0 & 0 & 0 \\
\hline
\end{tabular}

\section{Numerical Analysis}

Figures 2 and 3 show the relationship between the analyzed species and the micromorphological characters of the upper anthecium. The UPGMA dendrogram shows three clearly separated groups (Fig. 2). A high correlation of 0.91 was found between cophenetic matrix and similarity matrix. These major groups have no correspondence to taxonomic clades, nor genera or sections of Mesosetum.

The first three axes of PCA (Fig. 3) explained $71.74 \%$ of the total variation $(50.95 \%$ for axis $1,12.60 \%$ for axis 2 and $8.17 \%$ for axis 3 ). The characters that contributed more to the formation of the four groups were: presence or absence of papillae, quantity of papillae per epidermal cell, presence of hairs on the apex and presence of silica cells.

The absence of papillae was the most important character to distinguish $M$. pappophorum, $M$. exaratum, and $M$. filifolium from the other species (Fig. 2, 3). However, these species did not group.

Group 1 was composed by species of $M$. sect. Bifaria (Fig. 2, 3): M. alatum, M. bifarium, $M$. compressum, $M$. elytrochaetum, and $M$. longiaristatum. This group shares many characters, e.g. absence of papillae on the median surface, unicellular macrohairs on the median and distal surface, bicellular microhairs and silica cells.

Group 2 is comprised of $M$. arenarium, $M$. annuum, M. chlorostachyum, M. comatum Swallen, M. loliiforme, M. ansatum, M. chaseae, and Tatianyx arnacites (Fig. 2, 3). It has more than one papilla per cell, compound papillae, coalescence between the larger papillae, and hairy anthecium apex.

Group 3 is characterized by one papilla per epidermal cell and is composed of $M$. cayennense, $M$. ferrugineum, $M$. rottboellioides, $M$. agropyroides, $M$. gibbosum, M. penicillatum Mez, M. pittieri Hitchc., M. sclerochloa (Trin.) Hitchc., and Keratochlaena rigidifolia (Fig. 2, 3).

\section{Discussion}

Micromorphological characters of the upper anthecium have recognized taxonomic value and are widely used in the taxonomy of the Poaceae (Thompson \& Estes 1986; Filgueiras 2001; GiraldoCañas 2001; Oliveira et al. 2008). Our results reinforce the importance of such characters, but after analyzing several specimens some of the characters are more variable than previously expected and should be used carefully.

Sede et al. (2009) segregated the genera Oncorachis and Keratochlaena (under Sclerochlamys nom. illeg.) based on molecular data, and anatomical, morphological, and micromorphological characters. In their study, Mesosetum was reported to have a smooth anthecium, i.e. without papillae and open at the apex, based on M. cayennense and M. loliiforme. However, our results differ significantly. We analyzed populations of each of these Mesosetum species, from distinct localities (Tab. 1) and the upper anthecia was closed at the apex and covered by abundant verrucose papillae (Fig. 1j). Unfortunately, Sede et al. (2009) did not cite vouchers.

Sede et al. (2009) also reported the apex of the upper anthecium as glabrous in Keratochlaena rigidifolia (under Sclerochlamys) supporting the segregation of this species into a new genus Keratochlaena. However, we recorded prickly hairs on the upper anthecium apex in one voucher (Fig. 4a). On the other hand, a voucher of Tatianyx arnacites analyzed by Zuloaga \& Sorderstrom (1985) had prickly hairs on the upper anthecium, differing from the two specimens analyzed in this current study which had a glabrous upper anthecium apex (Fig. 4d).

Another major divergence was found in our study with that of Zuloaga \& Sorderstrom (1985). In our study, $T$. arnacites has simple papillae, and they are localized in depressions on the epidermis surface of the anthecium (Fig. 1f). In Zuloaga \& Soderstrom (1985) the papillae are compound and 

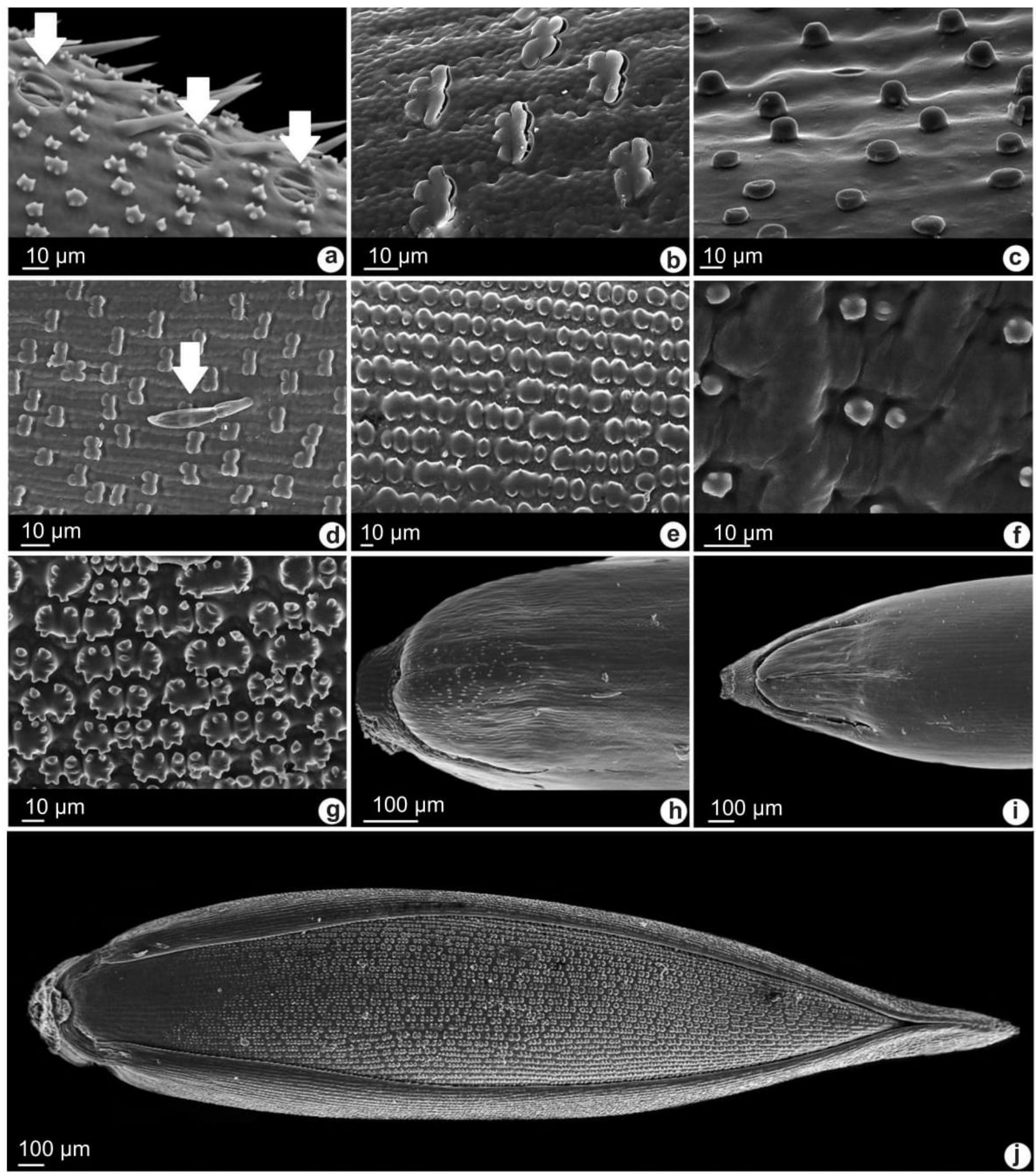

Figure 1 - a-g. Detail of the upper anthecium in some of the species analyzed. a. Mesosetum cayennense ( $R$. Haase 630) - stomata (arrow). b. M. filifolium (R.R. Innes 19) - silica cells. c. M. pittieri (H. Pittier 4516) - papillae. d. M. filifolium (C.R. Martins 998) - bicellular microhairs (arrow). e. M. annuum (A.S. Silva et al. 270) - papillae. f. Tatianyx arnacites (W. Ganev 2728) - papillae. g. M. chaseae (A. Pott et al 1771) - papillae. h. M. alatum (H. Jancoski et al. 444) - unilobed germination lid. i. M. elytrochaetum (R. C. Oliveira et al. 2722) - bilobed germination lid. j. upper anthecium of M. loliiforme (T.W. Henkel 5820).

not included in depressions. We have observed a wide morphological variation in Tatianyx and found distinct micromorphological characters of the upper anthecium, requiring reevaluation of this species.
In Arthropogoninae, the bicellular microhairs were observed only in species of Altoparadisium Filg., Davidse, Zuloaga \& Morrone, Canastra Morrone, Zuloaga, Davidse \& Filg. and Homolepis 


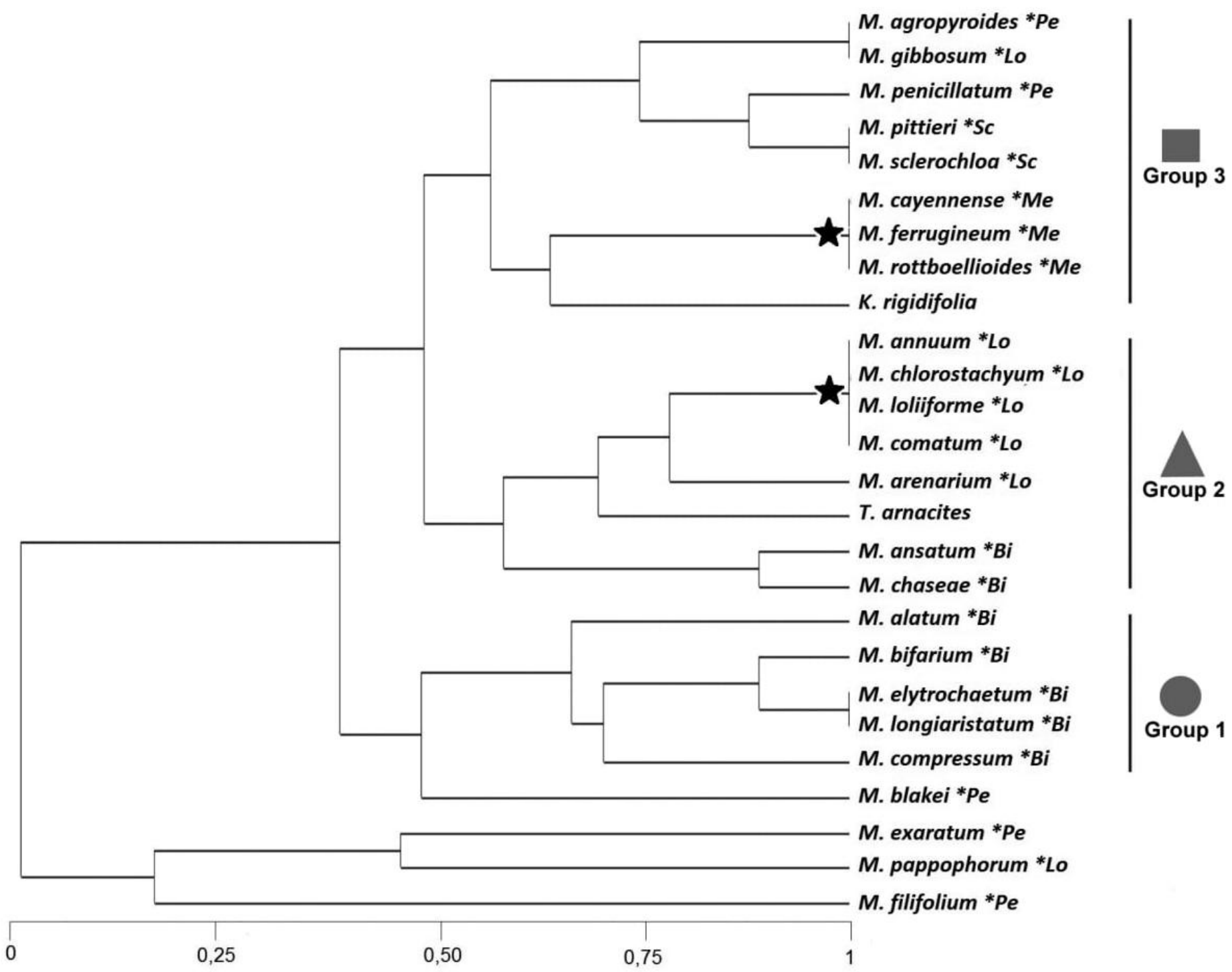

Figure 2 - UPGMA dendrogram based on Jaccard's similarity using micromorphological characters of the upper anthecium for Mesosetum, Tatianyx, and Keratochlaena species. *Bi. Mesosetum sect Bifaria. *Lo. Mesosetum sect Loliiformia. *Me. Mesosetum sect Mesosetum. *Pe. Mesosetum sect Penicillata. *Sc. Mesosetum sect Sclerochloae. *The classification of sections follows Filgueiras (1989). . Group 1. $\triangle$. Group 2. $\square$. Group 3. $\star$. Subgroups corresponding exactly to sections proposed by Filgueiras (1989).

(Zuloaga \& Soderstrom 1985; Filgueiras et al. 2001; Sede et al. 2008). Silica cells in Mesosetum have the form of crosses, with a minimum of two grooves (Fig. 1b), differing from those encountered in other members of Arthropogoninae whose silica cells has a dumbbell (halteriform) shape (Zuloaga \& Sorderstrom 1985; Filgueiras et al. 2001).

The germination lid is reported as little evident or conspicuous in Paniceae (Giraldo-Cañas 2004; Filgueiras et al. 2001). In Mesosetum all the species had a conspicuous germination lid, and we proposed two new character states for this structure, i.e. unilobed or bilobed.

According to Zucol (1998, 2000), the form of silica cells can show a minimum of two grooves, but it is more like lobes than grooves. They were mainly found in the distal portion of the abaxial surface of fertile lemma, like in the majority of Paniceae (Hsu 1935; Zuloaga \& Soderstrom 1985; Giraldo-Cañas 2004).

The SEM analyses helped to distinguish between the closely related taxa. Mesosetum annuиm and $M$. pappophorum, were previously distinguished by the length of spikelet hairs, according to Swallen (1937) and Filgueiras (1989). However, this character is variable between populations, and sometimes the overlapping of the hair length brings doubts if the species are indeed distinct. The micromorphology of the upper anthecium showed in the present study, supports the separation of these species with more certainty. Mesosetum annuum has papillae on all surfaces and a few hairs at the apex (Fig. 4b), while $M$. pappophorum shows a totally smooth and glabrous upper anthecium (Fig. 4e). 


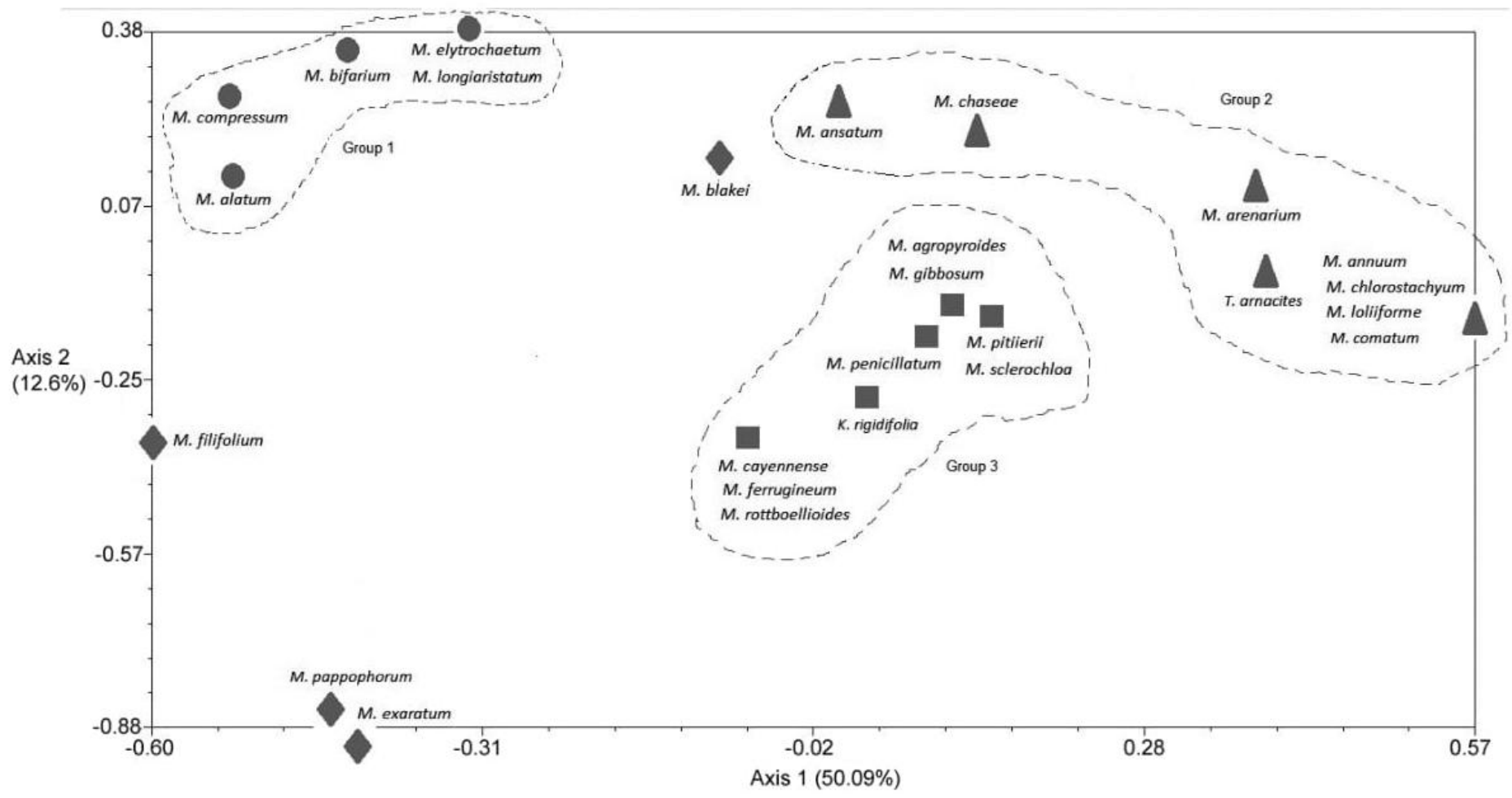

Figure 3 - PCA using micromorphological characters of the upper anthecium for Mesosetum, Tatianyx, and Keratochlaena species. Group 1. G. Group 2. Group 3. Species not grouped.

The character used by Filgueiras (1989) to separate $M$. alatum from $M$. bifarium (upper glume with tufts of hairs) is also inconsistent (Ribeiro 2013), when more samples are analyzed. Our results show that the best character is the germination lid. Mesosetum alatum is the only species in $M$. sect. Bifaria that has a unilobed germination lid and the width of this structure is equal to the dorsal spikelets, while in M. bifarium it is narrower. In addition, the anthecium has one papilla per cell in M. alatum, while it has at least three or more papillae per cell in M. bifarium (Tab. 2).

Another case where the morphological distinction was also supported by unstable characters is that of $M$. exaratum and $M$. filifolium. Swallen (1937) used the pilosity of the second glume to support their distinction, while Filgueiras (1989) put more value on the plant height and leaf blade length. Mesosetum filifolium shows silica cells and bicellular microhairs all over the upper anthecium surface, and a few macrohairs on the distal portion, while $M$. exaratum is glabrous and showed one silica cell in the three examined specimens.

There are two subgroups of species within the major groups of the dendrogram (Fig. 2, star) that coincide with the sections suggested by Filgueiras (1989). The species that compose the section
Mesosetum adopted by this author include $M$. cayennense, M. rottboellioides, and M. ferrugineum and it corresponds to the subgroup identified by one compound papillae per cell. This section is characterized by spikelets with ferruginous indumentum, which is an exclusive character (Filgueiras 1989). Species of this same group are associated with Keratochlaena rigidifolia, that is the sister group of Mesosetum genus. Similarities in chromosome size and number of species from $M$. sect. Mesosetum were also found by Sousa (2014).

Another subgroup found in the dendrogram using the upper anthecium micromorphological characters (Fig. 2, star) corresponds to the very homogenous $M$. sect. Loliiformia: M. annuum, $M$. arenarium, $M$. chlorostachyum, $M$. loliiforme and M. comatum. This section is characterized by spikelets with an inflated asymmetric lower glume and the second glume triangular (Filgueiras 1989). The upper anthecium of this group has more than one papilla per cell and coalescent papillae.

This study endorses the importance of the upper anthecium micromorphological characters for delimitation of Mesosetum species, but the taxonomic value of these characters are reduced for higher hierarchical levels. Also a new character is described, the germination lid bilobed, which has never before been mentioned. The lack of 

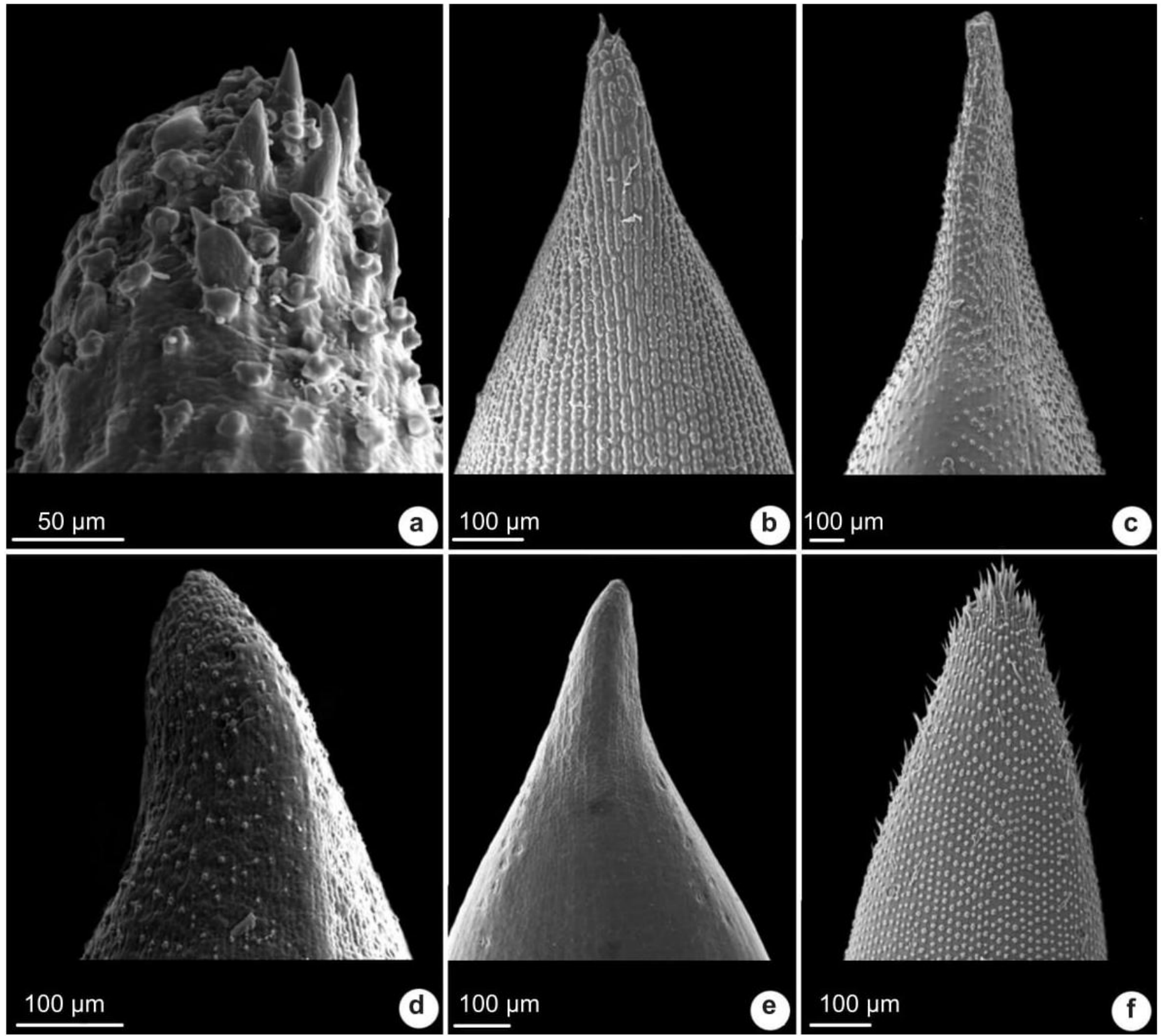

Figure 4 - Apex of the upper anthecium in some of the species analyzed. a. Keratochlaena rigidifolia (J.F.M. Valls et al. 8432). b. Mesosetum annuum (A.S. Silva et al. 270). c. M. pittieri (H. Pittier 4516). d. Tatianyx arnacites (W. Ganev 2728). e. M. pappophorum (A.S. Silva et al. 267). f. M. cayennense (R. Haase 630).

standard descriptive terms in Poaceae and the lack of correspondence between vouchers examined and the description morphological in SEM studies are still problematic, whereas it brings difficulties to compare species and their structures. More studies that include SEM additional character are needed to achieve a stronger systematic study of this group, accurate species identification, and more comprehensive biogeographical relationships.

\section{Acknowledgements}

This study was supported in part by Protax (562340/2010-6), Reflora and CNPq Edital Universal (474880/2012-5) and Capes for the doctorate grants to the first two authors. We are grateful to Sueli Maria Gomes for her assistance with the anatomy descriptions and help during revision of this paper.

\section{References}

Aliscioni, S.S.; Giussani, L.M.; Zuloaga, F.O. \& Kellogg, E.A. 2003. A molecular phylogeny of Panicum (Poaceae: Paniceae): tests of monophyly and phylogenetic placement within the Panicoideae. American Journal of Botany 90: 793-821.

Chase, A. 1911. Notes on genera of Paniceae 4. Proceedings Biological Society of Washington 24: 103-159.

Ellis, R. 1979. A procedure for standardizing comparative leaf anatomy in the Poaceae. II. The epidermis as seen in surface view. Bothalia 12: 641-671. 
Filgueiras, T.S. 1986. O gênero Mesosetum Steudel (Gramineae: Paniceae). Tese de Doutorado. Universidade Estadual de Campinas, Campinas. $344 \mathrm{p}$.

Filgueiras, T.S. 1989. Revisão de Mesosetum Steudel (Gramineae: Paniceae). Acta Amazônica 19: 47-114.

Filgueiras, T.S.; Davidse, G.; Zuloaga, F.O. \& Morrone, O. 2001. The establishment of the new genus Altoparadisium and a reevaluation of Arthropogon (Poaceae, Paniceae). Annals of the Missouri Botanical Garden 88: 351-372.

Filgueiras, T.S.; Silva, A.S. \& Oliveira, R.C. de. 2014. Mesosetum. In: Lista de Espécies da Flora do Brasil. Jardim Botânico do Rio de Janeiro. Available at $<\mathrm{http}$ //floradobrasil.jbrj.gov.br/jabot/floradobra.sil/ FB13355>. Access on 23 August 2014.

Giraldo-Cañas, D. 2001. Estudios micromorfológicos y anatómicos en el género Neotropical Axonopus (Poaceae: Paniceae). II. Antecio superior. Caldasia 24: 293-316.

Giraldo-Cañas, D. 2004. Características micromorfológicas y anatómicas de la espiguilla y el antecio superior del género Digitaria (Poaceae: Panicoideae: Paniceae). Caldasia 26: 1-35.

Giussani, L.M.; Cota-Sanchez, H.; Zuloaga F.O. \& Kellogg, E.A. 2001. A molecular phylogeny of the grass subfamily Panicoideae (Poaceae) shows multiple origins of $\mathrm{C} 4$ photosynthesis. American Journal of Botany 88: 1993-2012.

Grass Phylogeny Working Group (GPWG). 2011. New grass phylogeny resolves deep evolutionary relationships and discovers $\mathrm{C}_{4}$ origins. New Phytologist 193: 304-312.

Hsu, C. 1935. The classification of Panicum (Gramineae) and its allies, with special reference to the characters of lodicule, style-base and lemma. Journal of the Faculty of Science University of Tokyo 9: 43-150.

Johnston, C. \& Watson, L. 1981. Germination flaps in grass lemmas. Phytomorphology 31: 78-85.

Mejia-Saules, T. \& Bisby, F.A. 2003. Silica bodies and hooked papillae in lemmas of Melica species (Gramineae: Pooideae). Botanical Journal of the Linnean Society 141: 447-463.

Morrone, O. \& Zuloaga, F.O. 1991. Revision del género Streptostachys (Poaceae-Panicoideae), su posicion sistematica dentro de la tribu Paniceae. Annals of the Missouri Botanical Garden 78: 359-376.

Morrone, O.; Scataglini, A.M. \& Zuloaga, F.O. 2007. Cyphonanthus, a new genus segregated from Panicum (Poaceae: Panicoideae: Paniceae) based on morphological, anatomical and molecular data. Taxon 56: 521-532.

Morrone, O.; Aagesen, L.; Scataglini, M.A.; Salariato, D.L.; Denham, S.; Chemisquy, M.A.; Sede, S.M.; Giussani, L.M.; Kellogg, E.A. \& Zuloaga, F.O. 2012. Phylogeny of the Paniceae (Poaceae:
Panicoideae): integrating plastid DNA sequences and morphology into a new classification. Cladistics 1-24.

Oliveira, R.P.; Longhi-Wagner, H.M. \& Leite, K.R.B. 2008. A contribuição da anatomia foliar para a taxonomia de Raddia Bertol. (Poaceae: Bambusoideae). Acta Botanica Brasilica 22: 1-19.

Pilger, R. 1940. Gramineae. In: Engler, A \& Prantl, K. Die Natürlichen Pflanzenfamilen. 2ed, 14e. Wilhelm Engelmann, Leipzig. 208p.

Ribeiro, A.R.O. 2013. Citogenética, reprodução e variabilidade morfológica de espécies de Mesosetum sect. Bifaria (Hack.) Chase (Poaceae: Paspaleae). Dissertação de Mestrado, Universidade de Brasília, Brasília. 111p.

Rohlf, F. J. 2000. NTSYS-pc: numerical taxonomy and multivariate analysis system. Verion 2.1, Exeter Software, New York. 38p.

Rost, T.L. \& Simper, A.D. 1975. The germination lid: A characteristic of the lemma in the Paniceae. Madroño 23: 68-72.

Sede, S.M.; Morrone, O.; Giussani, L.M. \& Zuloaga, F.O. 2008. Phylogenetic studies in the Paniceae (Poaceae): a realignment of section Lorea of Panicum. Systematic Botany 33: 284-300.

Sede, S.M.; Morrone, O.; Aliscioni, S.S.; Giussani, L.M. \& Zuloaga, F.O. 2009. Oncorachis and Sclerochlamys, two new segregated genera from Streptostachys (Poaceae, Panicoideae, Paniceae): a revision based on molecular, morphological and anatomical characters. Taxon 58: 365-374.

Soderstrom, T.R. \& Zuloaga, F.O. 1989. A Revision of the Genus Olyra and the New Segregate Genus Parodiolyra (Poaceae: Bambusoideae: Olyreae). Smithsonian Contributions to Botany 69: 1-79.

Sousa, M.W.S. 2014. Citogenética e morfologia de espécies de Mesosetum Steud. (Poaceae, Paspaleae). Dissertação de Mestrado. Universidade de Brasília, Brasília. 61p.

Swallen, J.R. 1937. The grass genus Mesosetum. Brittonia 2: 363-392.

Thiers, B. (continuously updated). Index Herbariorum: A global directory of public herbaria and associated staff. New York Botanical Garden's Virtual Herbarium. Available at $<$ http://sweetgum.nybg. org/ih/>. Access on 17 August 2014.

Thompson, R. \& Estes, J. 1986. Anthecial and foliar micromorphology and foliar anatomy of Brachiaria. American Journal of Botany 73: 398-408.

Zucol, A. 1998. Microfitolitos de las Poaceae argentinas: II. Microfitolitos foliares de algunas especies del género Panicum (Poaceae, Paniceae) de la provincia de Entre Ríos. Darwiniana 36: 29-50.

Zucol, A. 2000. Fitolitos de Poaceae de Argentina. III. Fitolitos foliares de especies del género 
Paspalum (Paniceae) en la provincia de Entre Ríos. Darwiniana 38: 11-32.

Zuloaga, F.O. \& Soderstrom, T.R. 1985. Classification of the outlying species of New World Panicum (Poaceae: Paniceae). Smithsonian Contributions to Botany 59: 1-63.
Zuloaga, F.O.; Scataglini, M.A. \& Morrone, O. 2010. A phylogenetic evaluation of sects. Agrostoidea, Megista, Prionitia and Tenera of Panicum (Panicoideae, Poaceae): two new genera Stephostachys and Sorengia. Taxon 59: 1535-1546. 
Capítulo 5

Eleven new records of little known taxa of Mesosetum and Paspalum (Poaceae) from Brazil and Bolivia

Artigo publicado no periódico Phytotaxa 268 (1): 069-079

http://www.mapress.com/j/pt/

DOI: http://dx.doi.org/10.11646/phytotaxa.268.1.5 
http://dx.doi.org/10.11646/phytotaxa.268.1.5

\title{
Eleven new records of little known taxa of Mesosetum and Paspalum (Poaceae) from Brazil and Bolivia
}

\author{
ANÁDRIA STÉPHANIE DA SILVA ${ }^{1}$, DANIEL VILLARROEL ${ }^{1,2}$, ANDRÉ RODOLFO DE OLIVEIRA RIBEIRO ${ }^{1}$ \\ \& REGINA CÉLIA DE OLIVEIRA ${ }^{1,3}$ \\ ${ }^{\prime}$ Departamento de Botânica, Instituto de Ciências Biológicas, Universidade de Brasilia, DF, Brazil. \\ ${ }^{2}$ Herbario del Oriente Boliviano, Museo de Historia Natural Noel Kempff Mercado (UAGRM), Santa Cruz, Bolivia. \\ ${ }^{3}$ Author for correspondence: reginacelia@unb.br
}

\begin{abstract}
New records of Poaceae in Brazil and Bolivia are documented from expeditions, collections and review of herbarium specimens. Eleven new records are confirmed and comments, IUCN Threatened Species Categories and illustrations for these taxa are provided. Mesosetum comatum and M. filifolium are new records for Brazil, and M. ansatum is a new record for Bolivia. Paspalum burchellii, P. lepton, P. oteroi and P. trinitense are new records for Bolivia.
\end{abstract}

Key words: Gramineae, Paspaleae, flora, disjunct distribution

\section{Introduction}

Many species of Poaceae have been considered rare or even threatened by extinction, due to scanty documentation in herbaria. Upon further study, some such species have been revealed as occurring frequently, without threat of extinction, highlighting the essential role of expanding collection efforts and identification of herbarium specimens (Valls et al. 2009). Collection and identification is especially important in the smaller herbaria that are isolated from major urban centers and usually little visited by taxonomists.

Besides being bordering countries, there is a great affinity between the Bolivian and Brazilian flora of the Cerrado in the Chiquitanía region (Killeen \& Nee 1991, Navarro \& Ferreira 2004). Several lists and studies about geographical distribution patterns are available describing the diversity of Poaceae species in Brazil (e.g., Chase unpublished manuscript, Smith et al. 1982, Longhi-Wagner et al. 2001, Zuloaga \& Morrone 2005, Maciel \& Alves 2011, Soreng et al. 2014, Filgueiras et al. 2016) and Bolivia (Hitchcock 1927, Killeen 1990, Killeen \& Nee 1991, Killeen \& Hinz 1992, Killeen \& Schulenberg 1998, Meneses et al. 2014), new grass species to science are continually being discovered and geographical distributions of known taxa are routinely being expanded (Rua et al. 2008, Oliveira \& Valls 2008, Valls et al. 2009, Ramos et al. 2011, Bonasora et al. 2015, Oliveira et al. 2015, Reis et al. 2015).

Mesosetum Steudel (1854: 118) and Paspalum Linnaeus (1759: 846) are Neotropical genera of Poaceae that predominate in grassy vegetation formations in different biomes. The species of these genera have attracted interest for their ecological importance and for fodder (Ramírez 1954, Allem \& Valls 1987, Filgueiras 1992, Nascimento \& Renvoize 2001, Townsend et al. 2012). Mesosetum and Paspalum belong to the subfamily Panicoideae, the American tribe Paspaleae Presl (1830: 208), and to the subtribes Arthropogoninae Butzin (1972: 516) and Paspalinae Grisebach (1846: 468), respectively. The members of the American tribe Paspaleae share the basic chromosome number $\mathrm{x}=10$ (Morrone et al. 2012). However, some species of Paspalum and Mesosetum have other basic chromosome numbers (Peñaloza et al. 2008, Ribeiro et al. 2015, Bonasora et al. 2015).

Mesosetum species are characterized by a raceme-like solitary terminal inflorescence, spikelets with the first glume adaxial to the rachis, the glume and lower lemma with tufts of hairs and the caryopsis with a linear hilum (Filgueiras 1989). The first taxonomic review of Mesosetum was done by Swallen (1937), who recognized 33 species in the genus, based on collections from his extensive excursions through Brazil. Later, Filgueiras (1989) monographed the genus and accepted 25 species, based on his examination of herbarium collections available at the time. However, 
when Filgueiras $(1986,1989)$ reviewed the group, there was little representation of some species of Mesosetum in herbarium collections.

Species such as Mesosetum bifarium (Hackel 1897: 76) Chase (1911a: 123), M. longiaristatum Filgueiras (1987: 308) and M. sclerochloa (Trinius 1831: 283) Hitchcock (1909: 212) were described based only on the type material. Descriptions of M. agropyroides Mez (1918: 125), M. gibbosum Renvoize \& Filgueiras (1984: 181) and M. pittieri Hitchcock (1927: 85) were described from only two herbarium specimens each. Mesosetum alatum Filgueiras (1987: 306) and M. comatum Swallen (1940: 215) were known to Filgueiras (1989) from only three collections. Mesosetum compressum Swallen (1937: 367) was described from six collection records, all from the same expedition. This small representation of collections in herbaria reviewed by Filgueiras (1989) created the impression that many taxa of Mesosetum are rare and narrowly endemic, and that some species may be threatened.

Twenty-one species of Mesosetum are recorded in Brazil (Filgueiras et al. 2016). Killeen (1990) and Renvoize (1998) cited M. agropyroides and M. cayennense Steudel (1854: 118) in Bolivia, and Hitchcock (1927) reported M. rottboellioides (Kunth 1815a: 96) Hitchcock (1909: 211) in Bolivia. The occurrence of M. agropyroides and $M$. rottboellioides in Bolivia is discussed in this work.

Paspalum is characterized by racemiforme inflorescences with spikelets usually plano-convex, an upper adaxial lemma and, with few exceptions, by the lack of a lower glume (Oliveira \& Valls 2008). There is no revision covering all species of Paspalum. It is estimated that the genus includes 350 species (Zuloaga \& Morrone 2005), and 210 of them are documented in Brazil (Oliveira \& Valls 2016). According to Oliveira \& Valls (2016), 75 species and one variety of Paspalum are endemic to this country.

Renvoize (1998) reported 68 species of Paspalum in Bolivia, four of Thrasya Kunth (1815a: 120) and two of Reimarochloa Hitchcock (1909: 198), which were later transferred to Paspalum. Two species recognized by Renvoize (1998), P. kempffii Killeen (1990: 179) and P. macedoi Swallen (1967: 377), are considered synonyms of P. rojasii Hackel (1909: 369) (Oliveira \& Valls 2008). Paspalum remotum Rémy (1946: 349), recognized by Renvoize (1998), is a synonym for P. scrobiculatum Linnaeus (1767: 29) (Denham et al. 2010). Of the total accepted species in Bolivia, only P. candidum (Flüggé 1810: 214) Kunth (1815b: 68), P. campylostachyum (Hackel 1901: 367) Denham (2005: 489), $P$. crucense (Killeen 1990: 190) Denham (2005: 494), which is endemic to Bolivia, P. lepidum Chase in Hitchcock (1927: 447) (=P. inconstans Chase in Hitchcock (1927: 446)), P. procurrens Quarín (1993: 73), P. ekmanianum Henrard (1921: 49), P. pygmaeum Hackel (1912: 18), P. penicillatum Hooker (1847: 171) and P. prostratum Scribner \& Merrill (1901: 9) have not been reported for Brazil.

To support taxonomic, phylogenetic and cytogenetic research on Paspalum and Mesosetum, an extensive effort has been invested to review herbarium collections and to make new collections of these genera. The results of these efforts show that there are gaps in knowledge about the distribution of Paspalum and Mesosetum species, and that the apparent rarity of some species does not reflect their natural pattern. The aim of this study is to document new records of Paspalum and Mesosetum in Brazil and Bolivia, evaluate the degree of threat for some taxa, comment on relevant aspects of taxonomy and distribution of species, and provide illustrations and keys to help identify the poorly known taxa.

\section{Material and methods}

The material cited in this study is housed in the herbaria CEN, IBGE, K, MBM, R, UB, USZ and V (Thiers, continuously updated). Other herbaria have also been consulted over the last 10 years while working with these genera. New collections from Brazil and Bolivia were made by the authors. For identification, specialized bibliographies (cited in the text) were consulted and the types were compared.

The geographical distributions of the species treated here are based mainly on Filgueiras (1989), Killeen (1990), Renvoize (1998), Clayton et al. (2006 onwards), Filgueiras et al. (2016), the research websites Tropicos (2016) and Splink (2016), and other works cited in the text.

Each species was evaluated in terms of conservation status, based on the IUCN-Union for the Conservation of Nature and Natural Resources criteria (IUCN 2014). The criteria used were based on the distribution area and the estimated number of individuals.

Maps were made in with ArcGis software version 10.2 (ESRI 2012). The known records of Mesosetum and Paspalum species were obtained from the Splink (2016) database. Images of plants were obtained with a camera attached to Leica EZ4D stereomicroscope. Adobe Photoshop version 7.0 (San Jose, CA, USA) was used to prepare photos for publication. 
Micromorphological characters of the upper anthecium used in the identification key to species of Mesosetum sect. Loliiformia Swallen (1937: 380) were based on Silva et al. (2015).

\section{Results and discussion}

Two species of Mesosetum are newly recorded for the Brazilian flora: M. comatum Swallen (1940: 215) and M. filifolium Hubbard (1913: 494). One species, M. ansatum, is added to the Bolivian flora. Four species of Paspalum are added to Bolivia (P. burchellii Munro ex Oliver (1871: 80), P. lepton Schultes (1824: 173), P. oteroi Swallen (1967: 383), P. trinitense (Mez 1918: 125) Denham (2005: 521). The occurrence of M. sclerochloa (Trinius 1831: t.283) Hitchcock (1909: 212) in Brazil, which was previously known only from Mato Grosso, is expanded based on a new collection from Goiás. Paspalum phaeotrichum Valls et al. (2008: 267) in Brazil, previously documented only for the state of Bahia, was also found in Goiás. Four species of Paspalum are newly recorded from Bolivia: P. burchellii, P. lepton, P. oteroi, and P. trinitense. Paspalum burchellii and P. trinitense are already registered in the tropicos.org database based on our identifications.

Mesosetum agropyroides Mez (1918: 125). Type:-BRAZIL. Goiás: Civit Goyaz, 31 August 1895, Glaziou 22452 (holotype B!, isotypes BM!, K!, P!, S, US). (Fig. 1a)

Available descriptions of M. agropyroides (Mez 1918, Swallen 1937, Filgueiras 1989) were based on two collections made by Glaziou in 1895, without exact localities.

Our review of Brazilian herbaria revealed the occurrence of $M$. agropyroides in the states of São Paulo and Paraná (Fig. 3a). The collections from these states, made in 1949 and 1991, were previously determined only to family Poaceae. It is possible that there are more unidentified or mis-identified collections of this species in herbaria since it is a "rare" species, and is poorly known by taxonomists.

Mesosetum agropyroides can be recognized by robust and densely hairy spikelets that are 5 to $7 \mathrm{~mm}$ in length; it has some of the largest spikelets of the genus (Filgueiras 1989). The occurrence of M. agropyroides reported for Bolivia by Renvoize (1998) and Jørgensen et al. (2014) was checked. After careful analysis of the cited material (St.G. Beck 2068-USZ and J.R.I. Wood et al. 27037-USZ) we found that both sheets are M. penicillatum Mez (1918: 125) (Fig. 1b), which is distinguished from M. agropyroides by smaller spikelets and pilosity of the glumes and lower lemma. Mesosetum agropyroides has tuberculous trichomes covering the back of the upper glume, while M. penicillatum has one tuft of hair on the back of the upper glume and on the lower lemma (see Fig. 1a and 1b).

In all individuals of Mesosetum agropyroides that we have seen, there is evidence of the passage of fire, because of the absence of leaf blades and carbonized sheaths.

Specimens examined:-BRAZIL. Paraná: Jaguariaíva, campo próximo a ponte do Rio das Mortes, 16 December 1991, A.C. Cervi et al. 3575 (MBM). São Paulo: São Miguel Arcanjo, December 1949, J. Vidal III 129 (R).

IUCN Red List category:-VU (Vulnerable). Oliveira et al. (2009) cited this species, along with M. alatum and M. longiaristatum, as some of the rarest species in Brazil. The most recent herbarium record they reported was from 1991.

Mesosetum ansatum (Trin.) Kuhlmann (1922: 42). झ Panicum ansatum Trinius (1831: t. 279). Type:-BRAZIL. Mato Grosso: Cuiabá, January 1827, collector unknown, without number (holotype LE-TRIN-0570.01 photo!, isotypes MO2100915, US-80459). (Fig. 1d)

Mesosetum ansatum was previously known only from the state of Mato Grosso, Brazil. A recent collection reveals its presence in Bolivia (Fig. 3b). Mesosetum ansatum is recognized by having a widely winged rachis, frequently covering the spikelets, and spikelets laterally compressed. It is the only species of Mesosetum sect. Bifaria (Hackel 1897: 75) Chase (1911b: 121) that has white to yellowish stamens.

Populations grow in grassland areas or wetlands of the Pantanal region.

Specimens examined:-BOLIVIA. Santa Cruz Province: $3 \mathrm{~km}$ de Las Petas, 16²4'23”'S, 59¹0'32'W, $18 \mathrm{March}$ 2009, J.R.I. Wood \& D. Soto 25392 (UB, USZ).

IUCN Red List category:- LC (Least Concern). 

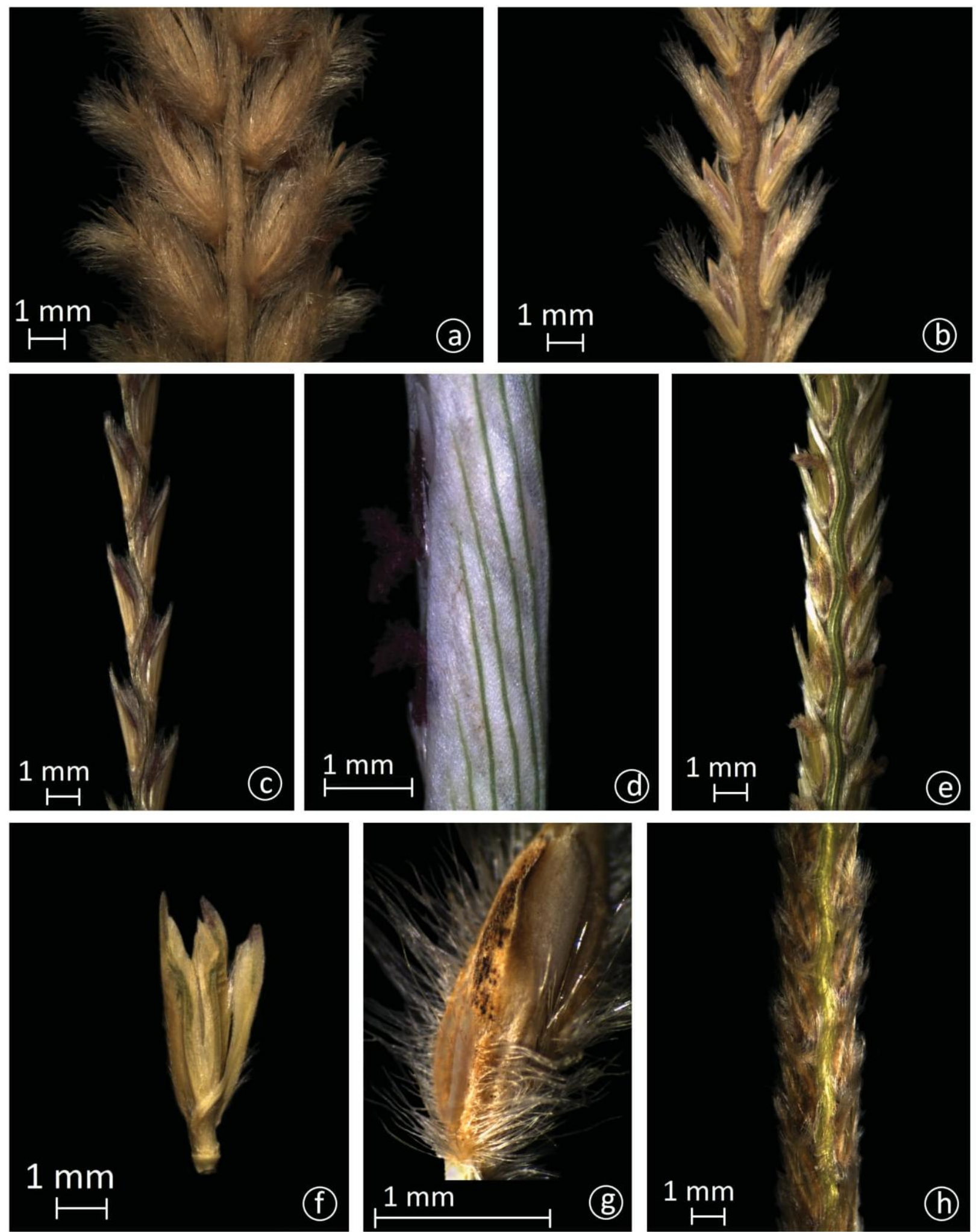

FIGURE 1. Photos of Mesosetum species: (a) detail of inflorescence of M. agropyroides Mez, J. Vidal III 129; (b) detail of inflorescence of M. penicillatum Mez, T.S. Filgueiras et al. 3472; (c) detail of inflorescence of M. filifolium F.T. Hubb., P.L. Viana 3438; (d) detail of rachis of M. ansatum (Trin.) Kuhlm., R.C. Oliveira et al. 2766; (e) detail of inflorescence of M. loliiforme (Hochst. ex Steud.) Chase, A.R.O. Ribeiro 425; (f) spikelet of M. sclerochloa (Trin.) Hitchcock, A.S. Silva 266; (g) spikelet of M. comatum Swallen, A.R.O. Ribeiro 418; (h) detail of inflorescence of M. comatum, A.R.O. Ribeiro 418. 
Mesosetum chaseae Luces (1942: 160). Type:-VENEZUELA. Anzoátegui: vicinity of Santomé, August-November 1940, A.G. Sandoval without number (holotype VEN, isotype US-1764957)

Mesosetum chaseae has the widest geographical distribution of the species in Mesosetum sect. Bifaria, recorded from Guatemala, Honduras, Venezuela, Trinidad and Tobago, Guyana, Brazil and Paraguay (Filgueiras 1989). Recently we found this species in Bolivia, which was also cited by Jørgensen et al. (2014), based on our identification of a sheet (Oliveira et al. 2981) in the USZ herbarium (Fig. 3c).

Filgueiras (1989) cited the occurrence of this species in Brazil, in the states of Mato Grosso do Sul, Minas Gerais and Roraima. We found Mesosetum chaseae in the states of Mato Grosso and Bahia, Brazil.

Mesosetum chaseae forms dense populations in the sandy soils of the Pantanal. It is often used as an important fodder.

Specimens examined:-BOLIVIA. Santa Cruz Province: Roboré, 18¹8’38'S, 5947'6.6”W, 13 December 2014, R.C. Oliveira et al. 2981 (UB, USZ). BRAZIL. Bahia: Lençóis, Serra da Chapadinha, 1247'44”S, 41²6'23”'W, 24 February 1995, E. Melo et al. 1733 (K); Mato Grosso: Poconé, 16²0'10”S, 56¹8’06”W, 25 May 2012, R.C. Oliveira et al. 2772 (UB).

IUCN Red List category:-LC (Least Concern).

Mesosetum comatum Swallen (1940: 215). Type:-ARGENTINA. Misiones: San Ignacio, Cerro Piedras, 10 March 1914, D. Rodriguez 31 (holotype US-1721241, isotype BAA). (Fig. 1g, h)

Mesosetum comatum is considered endemic to Argentina, with some records in Misiones (http://www.floraargentina. edu.ar/). It is here documented in Brazil for the first time in Chapada Diamantina, Bahia.

The two records of $M$. comatum coincide with a "diagonal of open formations" that extend across South America, from Maranhão to Ceará in north-northeastern Brazil to the Chaco in northern Argentina (Prado \& Gibbs 1993) (Fig. 3c). Greater collection effort would probably find new points of occurrence of M. comatum in Brazil along this diagonal.

The specimens of Brazilian M. comatum were analyzed and compared to those from a typical area in Argentina, together with the original description and analysis of the type material. There is no morphological discontinuity with taxonomic significance among these populations in Argentina and Brazil.

Along with six other species that occur in Brazil (Filgueiras 1989), Mesosetum comatum belongs to M. sect. Loliiformia. This section is characterized by an asymmetrical and distally inflated dorsal lower glume, and a triangular upper glume (Filgueiras 1989). Mesosetum comatum is characterized by conspicuously hirsute spikelets that have tuberculous trichomes in the proximal portion of the lower glume and on the marginal nerves of lower lemma. It can be mistaken for M. arenarium Swallen (1937: 380), M. gibbosum Renvoize \& Filgueiras (1984: 181) and M. loliiforme (Hochstetter ex Steudel 1854: 56) Chase (1911b: 302) (Fig.1e), which are perennial species of the section Loliiformia. We present an identification key of species of $M$. sect. Loliiformia below.

This species is very similar to other species of $M$. sect. Loliiformia. It can be easily confused with M. loliiforme, which has a wide distribution in the Neotropics.

Specimens examined:-BRAZIL. Bahia: Piatã, 134'43.2"S, 4147'19.7'W, 20 April 2015, A.R.O. Ribeiro \& J.E.Q. Faria 418 (UB); Palmeiras, 12²6'8”S, 41³1'4”'W, 26 March 2011, S.P.S. Neves 417 (HUEFS).

IUCN Red List category:-DD (Data Deficient). This species has a disjunct distribution, which makes it hard to identify and assess the population size.

\section{Key to species of Mesosetum sect. Loliiformia}

1. Annual

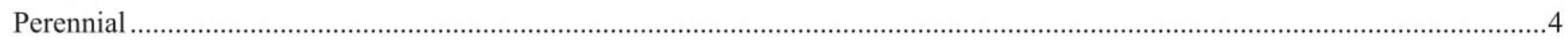

Spikelets uniseriate, glabrescent........................................................... chlorostachyum (Döll 1877: 173) Chase (1911a: 122)

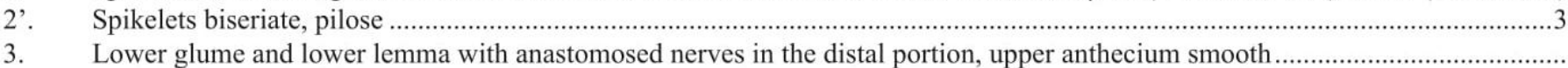

........................................................................................... M. pappophorum (Nees 1829: 104) Kuhlmann (1922: 90)

3'. Lower glume and lower lemma without anastomosed nerves in the distal portion, upper anthecium papillose......

M. annuum Swallen (1937: 377)

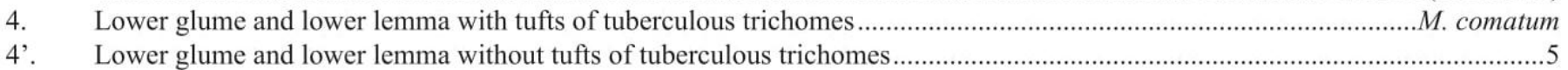

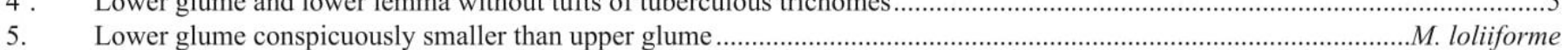


Mesosetum filifolium Hubbard (1914: 494). Type:-BRITISH HONDURAS. El Cayo: near Manatee Lagoon, pine ridge, 30 October 1905, M.E. Peck 136 (holotype GH). (Fig. 1c)

The known distribution of M. filifolium is in Central America, Mexico and Venezuela. According to specimen label data it grows in the sandy soils of savannas of Mountain Pine Ridge (Filgueiras 1989). Mesosetum filifolium was recently collected in the wetland of Canga vegetation in Carajás National Forest, Parauapebas, Pará, Brazil (Fig. 3b). Based on this collection, this taxon was included in the List of Species of the Brazilian Flora (Filgueiras et al. 2016).

Mesosetum filifolium is closely related to M. exaratum (Trinius 1826: 160) Chase (1911b: 121). It is distinguished by more elongated spikelets, distribution of trichomes on the glumes and a membranous upper anthecium. Silva et al. (2015) found micromorphological characters in the upper anthecium that further support the distinction of these species.

Specimens examined:-BRAZIL. Pará: Parauapebas, Serra Norte, 0602'24”S, 50¹6’38”W, 11 March 2008, C.R. Martins 998 (UB).

IUCN Red List category:-VU (vulnerable to regional level). Ore mining in the mountains of Serra de Carajás, Pará is causing devastation to the M. filifolium population in Brazil. In Central America, Mexico and Venezuela, this species is common and LC.
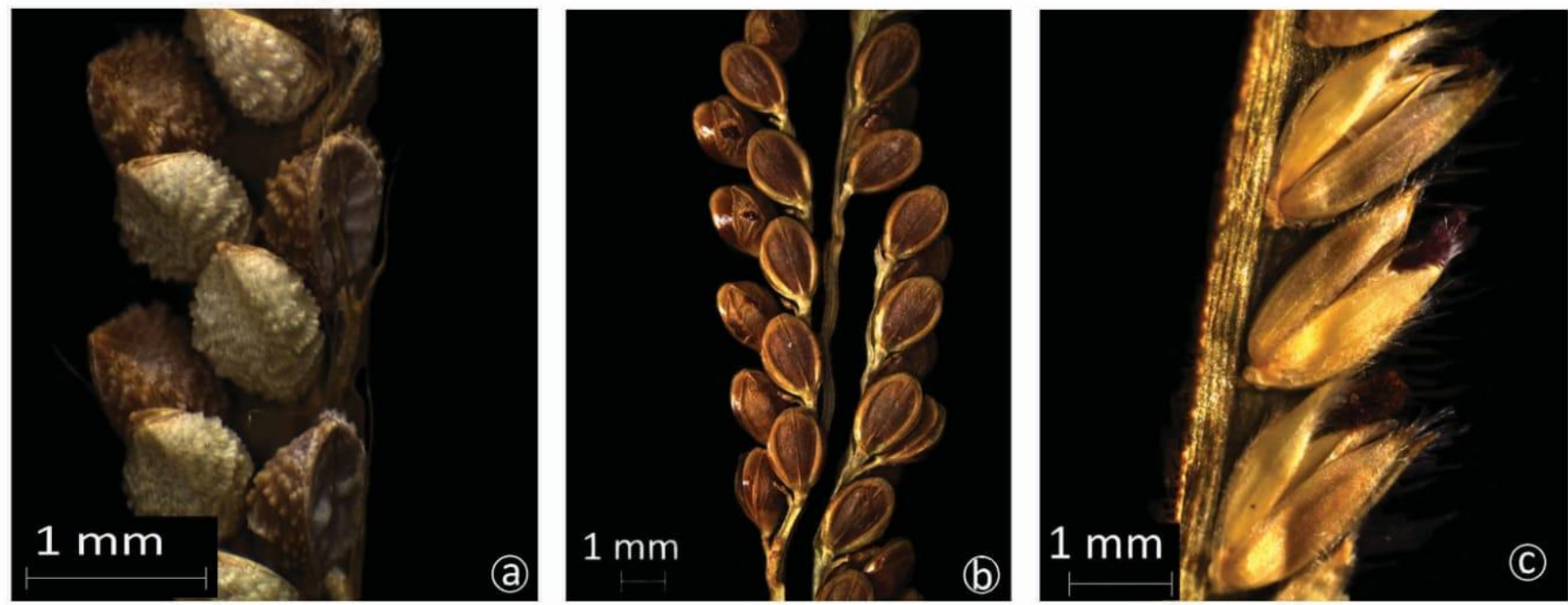

FIGURE 2. Photos of Paspalum species: (a) detail of inflorescence of P. burchellii Munro ex Oliv., J.R.I. Wood et al. 25784; (b) detail of inflorescence of P. lepton Schultes, J.R.I. Wood et al. 25733; (c) detail of inflorescence of P. trinitense (Mez) Denham, J.R.I. Wood et al. 26440 .

Mesosetum sclerochloa (Trin.) Hitchcock (1909: 212). 三 Panicum sclerochloa Trinius (1831: t.283) Type:-BRAZIL. Mato Grosso: Cuiabá, in humidis graminosis, February 1827, G.H. von Langsdorff without number (holotype LETRIN-0944.02 photo!, isotypes LE-TRIN-0944.01, US-80980). (Fig. 1f)

Filgueiras (1986) noted the deficiency of the original description of Mesosetum sclerochloa, based only on the type collected by Langsdorff in 1821 in Cuiabá, Mato Grosso, Brazil. Mesosetum sclerochloa (Fig. 1f) was collected in Goiás by Valls et al. (2009), 187 years after the original collection. Another specimen was collected by G.H. Rua et al. 958 (UB) in April 2011 in the state of Mato Grosso.

The present study records the occurrence of M. sclerochloa in the city of Flores de Goiás, state of Goiás (Fig. 3d). This species was collected several times by our group in this area, which indicates that its previous highlighted rarity is the result of scarce documentation of this species in herbaria, and not because of its scarce occurrence.

Mesosetum sclerochloa forms large populations in open areas of the Cerrado. It flowers and fruits intensely in the months February, March and April.

Specimens examined:-BRAZIL. Goiás: Flores de Goiás, 14²3'56'S, 47³'1'W, 14 April 2012, R.C. Oliveira \& A.R.O. Ribeiro 2739 (UB); 14²4’2.9”S, 47³’2.2”W, 02 March 2013, A.S. Silva et al. (UB). Mato Grosso: Nossa Senhora do Livramento, $16^{\circ} 6^{\prime} 33^{\prime \prime}$, 56 $50^{\circ} 19^{\prime} 54^{\prime \prime} \mathrm{W}, 16$ April 2011, G.H. Rua et al. 958 (UB).

IUCN Red List category:- LC (Least Concern). 

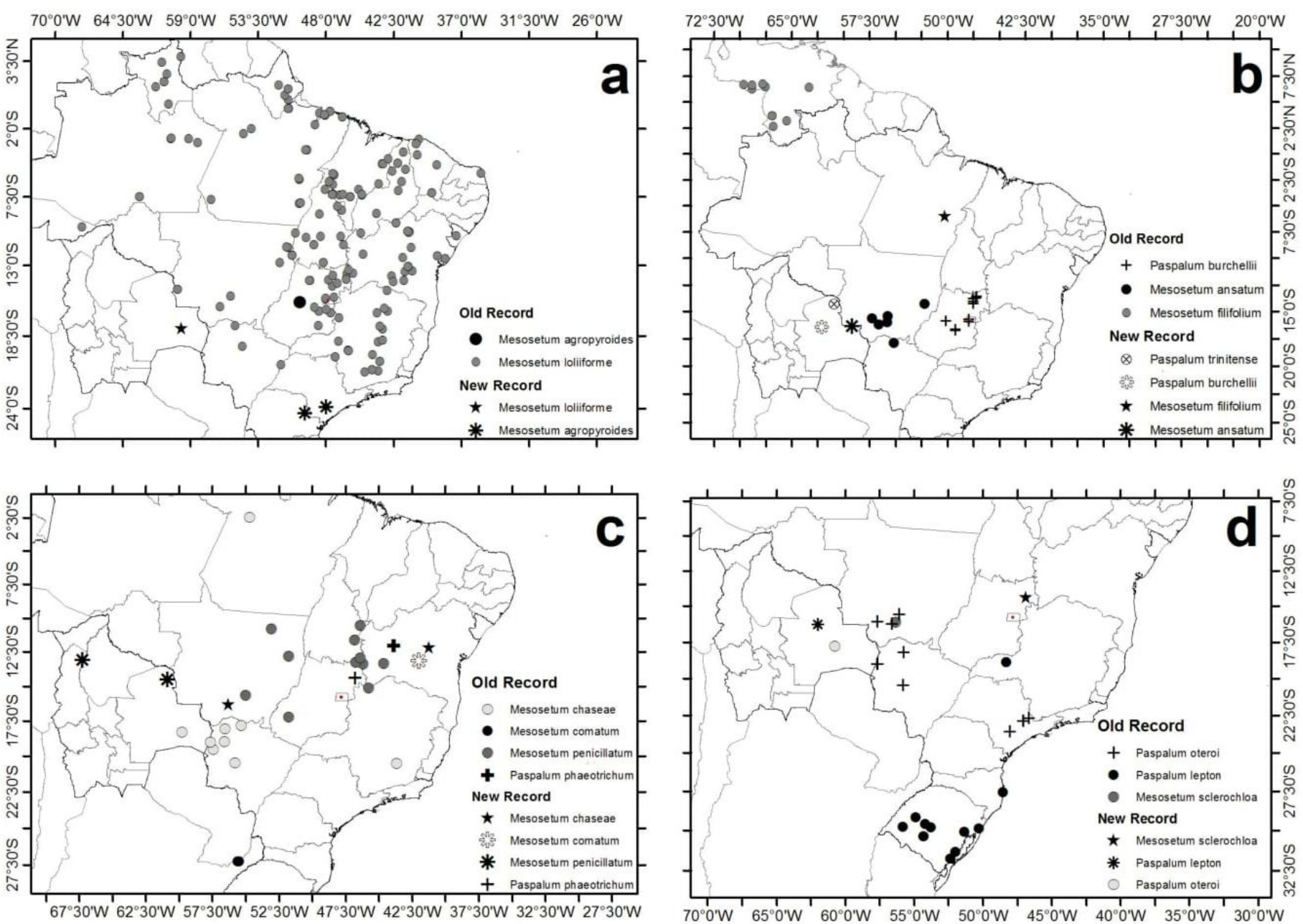

FIGURE 3. Distribution map with old and new records of Mesosetum and Paspalum species in Bolivia and Brazil: (a) Mesosetum agropyroides and M. loliiforme; (b) M. ansatum, M. filifolium, Paspalum burchellii and P. trinitense; (c) M. chaseae, M. comatum, M. penicillatum and P. phaeotrichum; (d) M. sclerochloa, P. lepton and P. oteroi.

Paspalum burchellii Munro ex Oliver (1871: 80). Type:-BRAZIL. Goias: goyaz, without date, W.J. Burchell 6844 (holotype K!, isotypes BR, P, US-952238, US-33284, US-2942162 (fragm. ex BR, K, W), W, L). (Fig. 2a)

Paspalum burchellii is recorded for Bolivia in Tropicos.org, based on our recent identification of a specimen collected in 2009 (Fig. 3b). This species inhabits sandy soils in the Cerrado.

Specimens examined:-BOLIVIA. Santa Cruz Province: Ñuflo de Chávez, 16³9'40”S, 6198'62”W, 18 March 2009, J.R.I. Wood et al. 25784 (UB, USZ).

IUCN Red List category:-LC (Least Concern).

Paspalum lepton Schultes (1824: 173). Type:-UNITED STATES. Georgia, without date, H.C. Muhlenberg Paspalum n. 8 (isotype US-2855320). (Fig. 2b)

Paspalum lepton was previously known only to the south of Brazil. A collection from Bolivia was recently determined in the UB and USZ herbaria by our group (Fig. 3d). Paspalum lepton is a rhizomatous species, which forms dense populations.

Specimens examined:-BOLIVIA. Santa Cruz Province: Ñuflo de Chávez, 16¹8'54"S, 6201'50”W, 16 March 2009, J.R.I. Wood et al. 25733 (UB, USZ) (Fig. 3d).

IUCN Red List category:- - LC (Least Concern).

Paspalum oteroi Swallen (1967: 383) Type:-BRAZIL. Rio de Janeiro: collected at the Secção Experimental de Agrostologia, 15 February 1950, J.R. de Otero s.n. (holotype US-2597973, isotype K!) 
Paspalum oteroi was previously considered to be endemic to Brazil (Oliveira \& Valls 2016). It is here documented in Bolivia for the first time. It was recently collected in Santiago de Chiquitos by our group (Fig. 3d).

Paspalum lepton and P. oteroi belong to the Plicatula group, recognized by Renvoize (1998) as a species complex. Species of the Plicatula group share a dark brown upper anthecium and a lower lemma usually with a hyaline portion in the median portion, which makes a seemingly dark anthecium with very characteristic transversal corrugations.

Paspalum oteroi is the only stoloniferous species of the Plicatula group, characterized by spikelets bearded proximally and hirsute distally. Paspalum lepton has leptomorph rhizomes with long internodes. This species is cultivated as forage in several parts of Brazil.

Specimens examined:-BOLIVIA. Santa Cruz Province: Caminho de San José, para San Ignacio de Velasco, após ca. $3 \mathrm{~km}$ do posto de pedágio, Santiago de Chiquitos, 17²7'13"'S, 6043'49"W, 14 December 2014, R.C. Oliveira et al. 2985 (UB) (Fig. 3d).

\section{IUCN Red List category:- LC (Least Concern).}

Paspalum phaeotrichum Valls, G.H. Rua, Graciano-Ribeiro \& R.C. Oliveira in Rua et al. (2008: 267). Type:BRAZIL. Bahia: Riachão das Neves, entrada de fazenda ca. $20 \mathrm{~km} \mathrm{~N}$ de Barreiras pela estrada antiga, $2 \mathrm{~km} \mathrm{~N}$ da ponte sobre o Rio Branco, 31 March 1983, J.F.M. Valls, A. Krapovickas, R.F.A. Veiga, \& G. Pereira-Silva 7049 (holotype CEN!, isotypes BAA!, L!, RB!, SI!, US!).

Paspalum phaeotrichum was previously known only from the type from Bahia. It was recently collected in Flores de Goiás, Goiás, by our group (Fig. 3c).

Specimens examined:-BRAZIL. Goiás: Flores de Goiás, estrada para Nova Roma, $9 \mathrm{Km}$ após a ponte, 14²4'2.9’'S, 47³'2.2”W, 2 March 2013, A.S. Silva et al. 268 (CEN, UB).

IUCN Red List category:-DD (Data Deficient). There are only two known populations of this species, growing in sandy soils in transition areas between Cerrado and Caatinga vegetation.

Paspalum trinitense (Mez) Denham (2005: 521). 三 Thrasya trinitensis Mez (1918: 125). Type:-TRINIDAD and TOBAGO. Trinidad: Piarco Savanna, 25 March 1893, W.E. Broadway 5294 (holotype B, isotype US-81807). (Fig. 2c)

Paspalum trinitense has been recorded only in Brazil in the states of Mato Grosso and Tocantins (Oliveira \& Valls 2016). Here we report this species from Bolivia. Paspalum trinitense inhabits savannas and grasslands in sandy soils from sea level to $1400 \mathrm{~m}$ elevation (Denham 2005).

Specimens examined:-BOLIVIA. Santa Cruz: Province Velasco, 17 November 2009, J.R.I. Wood et al. 26440 (UB, USZ) (Fig. 3b).

IUCN Red List category:- - LC (Least Concern).

\section{Acknowledgements}

This study was supported in part by CNPq Edital Universal (474880/2012-5) and CAPES (Coordenação de Aperfeiçoamento de Pessoal de Nível Superior), who provided Doctoral grants to the first three authors. We thank the curators and staff of CEN, IBGE, K, MBM, R, USZ and V herbaria for loans of specimens. We are sincerely grateful to Janae Million and Michael H. Nee for revision of the language. We also thank Moises Mendoza and Jair Faria for support in botanical expeditions.

\section{References}

Allem, A.C. \& Valls, J.F.M. (1987) Recursos forrageiros nativos do pantanal Matogrossense, Documentos 8. Embrapa/DID, Embrapa/ Cenargen, Brasília-DF, 339 pp.

Bonasora, M.G., Pozzobon, M.T., Honfi, A.I. \& Rua, G.H. (2015) Paspalum schesslii (Poaceae, Paspaleae), a new species from Mato Grosso (Brazil) with an unusual base chromosome number. Plant Systematics and Evolution 301: 2325-2339.

http://dx.doi.org/10.1007/s00606-015-1231-0

Butzin, F. (1972) Zur Nomenklatur und Taxonomie der Arthropogoneae (Gramineae, Panicoideae). Willdenowia 6: $511-517$. 
Chase, M.A. (1911a) Notes on genera of Paniceae IV. Proceedings of the Biological Society of Washington 24: $103-160$. http://dx.doi.org/10.5962/bhl.title.53634

Chase, M.A. (1911b) Additions to the grasses of Cuba. Botanical Gazette 51: 300-302. http://dx.doi.org/10.1086/330491

Clayton, W.D., Vorontsova, M.S., Harman, K.T. \& Williamson, H. (2006 onwards) GrassBase-The Online World Grass Flora. Available from: http://www.kew.org/data/grasses-db.html. (accessed: 1 March 2016)

Denham, S.S. (2005) Revisión sistemática del subgénero Harpostachys de Paspalum (Poaceae: Panicoideae: Paniceae). Annals of the Missouri Botanical Garden 92 (4): 463-532.

Denham, S.S., Morrone, O. \& Zuloaga, F.O. (2010) Estudios en el género Paspalum (Poaceae, Panicoideae, Paniceae): Paspalum denticulatum y especies afines. Annals of Missouri Botanical Garden 97 (1): 11-33.

http://dx.doi.org/10.3417/2008092

Döll, J.C. (1877) Gramineae I. Paniceae. In: Martius, C.F.P. (Ed.) Flora Brasiliensis 2: 33-358.

ESRI (2012) ArcGIS 10.2. Environmental Systems Research Institute Inc, USA.

Filgueiras, T.S. (1986) O gênero Mesosetum Steudel (Gramineae: Paniceae). Tese de Doutorado. Universidade Estadual de Campinas, Campinas, $344 \mathrm{pp}$.

Filgueiras, T.S. (1987) Two new species of Mesosetum (Gramineae: Paniceae) from Brazil. Brittonia 39: 306-308. http://dx.doi.org/10.2307/2807402

Filgueiras, T.S. (1989) Revisão de Mesosetum Steudel (Gramineae: Paniceae). Acta Amazônica 19: 47-114. http://dx.doi.org/10.1590/1809-43921989191114

Filgueiras, T.S. (1992) Gramíneas forrageiras nativas no Distrito Federal, Brasil. Pesquisa Agropecuária Brasileira 27: $1103-1111$.

Filgueiras, T.S., Canto-Dorow, T.S., Carvalho, M.L.S., Dórea, M.C., Ferreira, F.M., Mota, A.C., Oliveira, R.C., Oliveira, R.P., Reis, P.A., Rodrigues, R.S., Santos-Gonçalves, A.P., Shirasuna, R.T., Silva, A.S., Silva, C., Valls, J.F.M., Viana, P.L., Welker, C.A.D., Zanin, A. \& Longhi-Wagner, H.M. (2016) Poaceae in Lista de Espécies da Flora do Brasil. Jardim Botânico do Rio de Janeiro. Available from: http://floradobrasil.jbrj.gov.br/jabot/floradobrasil/FB193 (accessed 1 March 2016)

Flüggé, J. (1810) Graminum Monographiae. Pars. I. Paspalus. Reimaria. Impensis F. Perthes et J. H. Besser, Hamburgi, 224 pp. http://dx.doi.org/10.5962/bhl.title.15639

Grisebach, A.H.R. (1846) Spicilegium florae rumelicae et bithynicae exhibens synopsin plantarum quas in aest. 1839 legit auctor A. Grisebach 2. Friedrich Vieweg und Sohn, Braunschweig, pp. 161-548.

Hackel, E. (1897) Bifaria, eine neue Section der Gattung Panicum. Oesterreichische Botanische Zeitschrift 47: 73-77. http://dx.doi.org/10.1007/BF01793876

Hackel, E. (1901) Neue Gräser In: Wittstein, R.R. (Ed.) Oesterreichische Botanische Zeitschrift. Verlag und Druck von Carl Gerold's Sohn, Wien, pp. 366-374.

Hackel, E. (1909) Ex herbario Hassleriano: Novitates paraguariensis III. Repertorium Specierum Novarum Regni Vegetabilis 7: 369374.

http://dx.doi.org/10.1002/fedr.19090072211

Hackel, E. (1912) Gramineae novae IX. Repertorium Specierum Novarum Regni Vegetabilis 11: 18-30. http://dx.doi.org/10.1002/fedr.19120110104

Henrard, J.T. (1921) Gramineae. In Herzog's bolivianische Pflanzen, V. Mededeelingen van's Rijks-Herbarium 40: 39-77.

Hitchcock, A.S. (1909) The grasses of Cuba. Contributions from the United States National Herbarium 12 (6): 1-474. http://dx.doi.org/10.5962/bhl.title.53682

Hitchcock, A.S. (1927) The grasses of Ecuador, Peru, and Bolivia. Contributions from the United States National Herbarium 24 (8): $291-556$.

Hooker, J.D. (1847) An enumeration of the plants of the Galapagos Archipelago; with descriptions of those which are new. Transactions of the Linnean Society of London 20 (2): 163-233.

http://dx.doi.org/10.1111/j.1096-3642.1846.tb00416.x

Hubbard, F.T. (1913) On the Gramineae collected by Prof. Morton E. Peck in British Honduras. Proceedings of the American Academy of Arts and Sciences 49 (8): 493-502.

http://dx.doi.org/10.2307/20025477

IUCN (2014) Guidelines for Using the IUCN Red List Categories and Criteria. Version 11. Prepared by the Standards and Petitions Subcommittee. Available from: http:/www.iucnredlist.org/documents/RedListGuidelines.pdf (accessed 29 February 2016)

Jørgensen, P.M., Nee, M.H. \& Beck, S.G. (2014) Catálogo de las plantas vasculares de Bolivia. Monographs in Systematic Botany from the Missouri Botanical Garden 127 (1-2): 1-1744.

Killeen, T. (1990) The grasses of Chiquitania, Santa Cruz, Bolivia. Annals of the Missouri Botanical Garden 77: $172-181$. http://dx.doi.org/10.2307/2399632

Killeen, T.J. \& Nee, M. (1991) Catálogo de las plantas sabaneras de Concepción, Departamento Santa Cruz, Bolivia. Ecología en Bolivia 
16: $53-71$.

Killeen, T.J. \& Hinz, P.N. (1992) Grasses of the Precambrian Shield Region in Eastern Lowland Bolivia. I. habitat preferences. Journal of Tropical Ecology 8 (4): 389-407.

Killeen, T.J. \& Schulenberg, T.S. (1998) A biological assessment of Parque Nacional Noel Kempff Mercado, Bolivia. Rapid Assessment Program Working Papers 10: 1-372.

Kuhlmann, J.G. (1922) Gramíneas. Commissão de Linhas Telegraphicas Estrategicas de Matto Grosso ao Amazonas, Botanica 67: 1-95. http://dx.doi.org/10.5962/bhl.title.53519

Kunth, C.S. (1815a) Gramineae. In: Humboldt, A., Bonpland, A. \& Kunth, K. (Eds.) Nova genera et species plantarum (quarto ed.) 1. Lutetiae Parisiorum: sumtibus librariae Graeco-Latini-Germanicae, pp. 84-201.

Kunth, C.S. (1815b) Considérations générales sur les Graminées Mémoires du Muséum d'Histoire Naturelle 2: 62-75.

Linnaeus, C. (1759) Systema Naturae, ed. 10. 2. Laurentii Salvii, Stockholm, 846 pp.

Linnaeus, C. (1767) Mantissa Plantarum 1. Laurentii Salvii, Stockholm, 142 pp.

Longhi-Wagner, H.M., Bittrich, V., Wanderley, M.G.L. \& Shepherd, G.J. (2001) Poaceae. In: Wanderley, M.G.L., Shepherd, G.J. \& Giulietti, A.M. (Eds.) Flora Fanerogâmica do Estado de São Paulo. Hucitec, São Paulo, pp. 1-292.

Luces, Z. (1942) New grasses from Venezuela. Journal of the Washington Academy of Sciences 32 (6): 157-166.

Maciel, J.R. \& Alves, M. (2011) A família Poaceae na Serra de Itabaiana, Parque Nacional Serra de Itabaiana, Sergipe-Brasil. Caatinga 24: 85-93.

Meneses, R.I., Larrea-Alcázar, D.M., Beck, S.G. \& Espinoza, S. (2014) Modelando patrones geográficos de distribución de gramíneas (Poaceae) en Bolivia: Implicaciones para su conservación. Ecología en Bolivia 49 (1): 3-19.

Mez, C. (1918) Sacciolepis, Mesosetum, Thrasia, Ichnanthus genera speciebus novis aucta. Repertorium Specierum Novarum Regni Vegetabilis 15: 122-133.

http://dx.doi.org/10.1002/fedr.19180150803

Morrone, O., Aagesen. L., Scataglini, M.A., Salariato, D.L., Denham, S.S., Chemisquy, M.A., Sede, S.M., Giussani, L.M., Kellogg, E.A. \& Zuloaga, F.O. (2012) Phylogeny of the Paniceae (Poaceae: Panicoideae): integrating plastid DNA sequences and morphology into a new classification. Cladistics 28: 333-356.

http://dx.doi.org/10.1111/j.1096-0031.2011.00384.x

Nascimento, M.P.S.C.B. \& Renvoize, S.A. (2001) Gramíneas Forrageiras Naturais e Cultivadas na Região Meio-Norte. Embrapa MeioNorte, Teresina, $196 \mathrm{pp}$.

Navarro, G. \& Ferreira, W. (2004) Zonas de vegetación potencial de Bolivia: Una base para el análisis de vacíos de conservación. Bolivia Ecológica 15: 1-40.

Nees, C.G. (1829) Agrostologia brasiliensis. In: Martius, C.F.P. (Ed.) Flora Brasiliensis seu Enumeratio Plantarum 2. J.G. Cottae, Stuttgart \& Tübingen, pp. 1-608.

http://dx.doi.org/10.5962/bhl.title.6159

Oliver, D. (1871) Plate 1100. Paspalum burchellii. Gramineae. Hooker's Icones Plantarum 11: 80.

Oliveira, R.P., Longhi-Wagner, H.M., Filgueiras, T.S., Mota, A.C. \& Viana, P.L. (2009) Poaceae. In: Giulietti, A.M., Rapini, A., Andrade, M.J.G., Queiroz, L.P. \& Silva, J.M.C. (Eds.)Plantas Raras do Brasil. Conservação Internacional, Universidade Estadual de Feira de Santana, Belo Horizonte-MG, 496 pp.

Oliveira, R.C. \& Valls, J.F.M. (2008) Novos sinônimos e ocorrências em Paspalum L. (Poaceae). Hoehnea 35 (2): 125 -131. http://dx.doi.org/10.1590/S2236-89062008000200010

Oliveira, R.C. \& Valls, J.F.M. (2016) Paspalum in Lista de Espécies da Flora do Brasil. Jardim Botânico do Rio de Janeiro. Available from: http://floradobrasil.jbrj.gov.br/jabot/floradobrasil/FB13432 (accessed 1 March 2016)

Oliveira, R.C., Valls, J.F.M., Gomes, S.M., Fagg, C.W. \& Pozzobon, M.T. (2015) A new species of Paspalum, Notata group (Poaceae, Paspaleae), from the Cerrado biome, Brazil: description, chromosome number, and leaf blade anatomy. Phytotaxa 203 (2): $159-168$. http://dx.doi.org/10.11646/phytotaxa.203.2.5

Peñaloza, A.P.S., Côrtes, A.L., Pozzobon, M.T., Santos, S., Rua, G.H., Valls, J.F.M. (2008) Unusual chromosome numbers in Paspalum L. (Poaceae: Paniceae) from Brazil. Genetics and Molecular Research 7: 399-406.

http://dx.doi.org/10.1590/S0103-84782008000500014

Prado, D.E. \& Gibbs, P.E. (1993) Patterns of species distributions in the dry seasonal forests of South America. Annals Missouri Botanical Garden 80: 902-927.

http://dx.doi.org/10.2307/2399937

Presl, J.S. (1830) Gramineae. In: Presl, K.B. (Ed.) Reliquiae Haenkeanae seu descriptiones et icones plantarum, quas in America meridionali et boreali, in insulis Philippinis et Marianis collegit Thaddeus Haenke, rede-git et in ordinem digessit Carolus Bor: Presl 1(4/5). J.G. Galve, Prague, pp. 207-355.

http://dx.doi.org/10.5962/bhl.title.515 
Quarín, C.L. (1993) Morfología, citología y sistema reproductivo de una nueva especie de gramínea: Paspalum procurrens. Boletín de la Sociedad Argentina de Botánica 29: 73-76.

Ramirez, J.R. (1954) El pasto rojas. Revista Argentina de Agronomía 21 (2): 84-101.

Ramos, D.M., Valls, J.F.M., Oliveira, R.C. \& Graciano-Ribeiro, D. (2011) A new awned species of Paspalum (Poaceae, Panicoideae, Paniceae) from Brazil. Novon: A Journal for Botanical Nomenclature 21 (3): 368-372.

http://dx.doi.org/10.3417/2010033

Reis, P.A., Silva, A.L.H., Silva, A.S., Valls, J.F.M., Gomes, S.M. \& Oliveira, R.C. (2015) Paspalum minutispiculatum (Poaceae, Panicoideae): A new annual species from Central Brazil. Systematic Botany 40 (3): 746-754. http://dx.doi.org/10.1600/036364415X689203

Rémy, E.J (1946) Analecta Boliviana. Annales des Sciences Naturelles, Botanique 3: 348-349.

Renvoize, S. \& Filgueiras, T.S. (1984) New grasses from Bahia. Kew Bulletin 39 (1): 179-183. http://dx.doi.org/10.2307/4107868

Renvoize, S. (1998) Gramíneas de Bolivia. Royal Botanic Garden, Kew, 644 pp.

Ribeiro, A.R.O., Sousa, M.W.S., Oliveira, R.C., Araujo, A.C.G., Fagg, C.W. \& Pozzobon, M.T. (2015) Cytological studies in four species of Mesosetum (Arthropogoninae) reveal the lowest chromosome number among the Neotropical Poaceae. Plant Systematics and Evolution 301: 2377-2386. http://dx.doi.org/10.1007/s00606-015-1234-x

Rua, G.H., Valls, J.F.M., Graciano-Ribeiro D. \& Oliveira, R.C. (2008) Four new species of Paspalum (Poaceae, Paniceae) from Central Brazil, and resurrection of an old one. Systematic Botany 33 (2): 267-276. http://dx.doi.org/10.1600/036364408784571671

Schultes, J.A. (1824) Paspalus. Mantissa 2: 166-176. http://dx.doi.org/10.5962/bhl.title.552

Scribner, F.L. \& Merrill, E.D. (1901) Some recent collections of Mexican grasses. Bulletin, Division of Agrostology United States Department of Agriculture 24: 5-31.

Silva, A.S., Ribeiro, A.R.O., Sousa, M.W.S., Fagg, C.W., Falcão, R. \& Oliveira, R.C. (2015) Micromorphology of the upper anthecium in Mesosetum Steud. and related genera (Poaceae, Arthropogoninae) and its taxonomic applications. Rodriguésia 66 (2): $645-657$. http://dx.doi.org/10.1590/2175-7860201566227

Smith, L.B., Wasshausen, D.C. \& Klein, R.M. (1982) Gramíneas. In Reitz, R. (Ed.) Flora ilustrada catarinense. Herbário Barbosa Rodrigues, Itajaí, $1407 \mathrm{pp}$.

Soreng, R.J., Davidse, G., Peterson, P.M., Zuloaga, F.O., Judziewicz, E.J., Filgueiras, T.S. \& Morrone, O. (2014) Catalogue of New World Grasses (Poaceae). Available from: http://www.tropicos.org/projectwebportal. aspx?pagename $=$ Home\&projectid=10 (accessed: 1 March 2016)

Splink.org (2016) Species Link. Centro de Referência em Informação Ambiental - CRIA. Available from: http://www.splink.org.br/ (accessed 1 March 2016)

Steudel, E.G. von (1854) Gramineae. Synopsis Plantarum Glumacearum 1. J. B. Metzler, Stuttgartle, 474 pp. http://dx.doi.org/10.5962/bhl.title.471

Swallen, J.R. (1937) The grass genus Mesosetum. Brittonia 2: 363-392. http://dx.doi.org/10.2307/2804761

Swallen, J.R. (1940) Miscellaneous new American grasses. Journal of the Washington Academy of Sciences 30: $209-217$.

Swallen, J.R. (1967) New species of Paspalum. Phytologia 14 (6): 358-389. http://dx.doi.org/10.5962/bhl.part.18532

Thiers, B. (2016; continuously updated) Index Herbariorum: A global directory of public herbaria and associated staff. New York Botanical Garden's Virtual Herbarium. Available from: http://sweetgum.nybg.org/ih/ (accessed 1 March 2016)

Townsend, C.R., Costa, N.L. \& Pereira, R.G.A. (2012) Pastagens Nativas na Amazônia Brasileira, Documentos 149. Embrapa, Porto Velho, $25 \mathrm{pp}$.

Trinius, C.B. (1826) De Graminibus Paniceis. Dissertatio botanica altera. Impensis Academiae Imperialis Scientiarum, Saint Petersburg, 289 pp. http://dx.doi.org/10.5962/bhl.title.15256

Trinius, C.B. (1831) Species Graminum: iconibus et descriptionibus illustravit 3 (24): t. 241-360.

Tropicos (Org.) (2016) Missouri Botanical Garden. Available from: http://www.tropicos.org (accessed 1 March 2016).

Valls, J.F.M., Ramos, D.M., Peñaloza, A.P.S. \& Santos, S. (2009) Nota sobre a ocorrência e distribuição geográfica de Mesosetum sclerochloa (Trin.) Hitchc., graminea brasileira com rarissimas coletas, Resumos do 60 Congresso Nacional de Botânica (on DVD). EDUNEB, Salvador, $666 \mathrm{pp}$.

Zuloaga, F.O. \& Morrone, O. (2005) Revisión de las especies de Paspalum para América del Sur Austral (Argentina, Bolivia, Sur del Brasil, Chile, Paraguay y Uruguay). Monographs in Systematic Botany from the Missouri Botanical Garden 102: 1-297. 


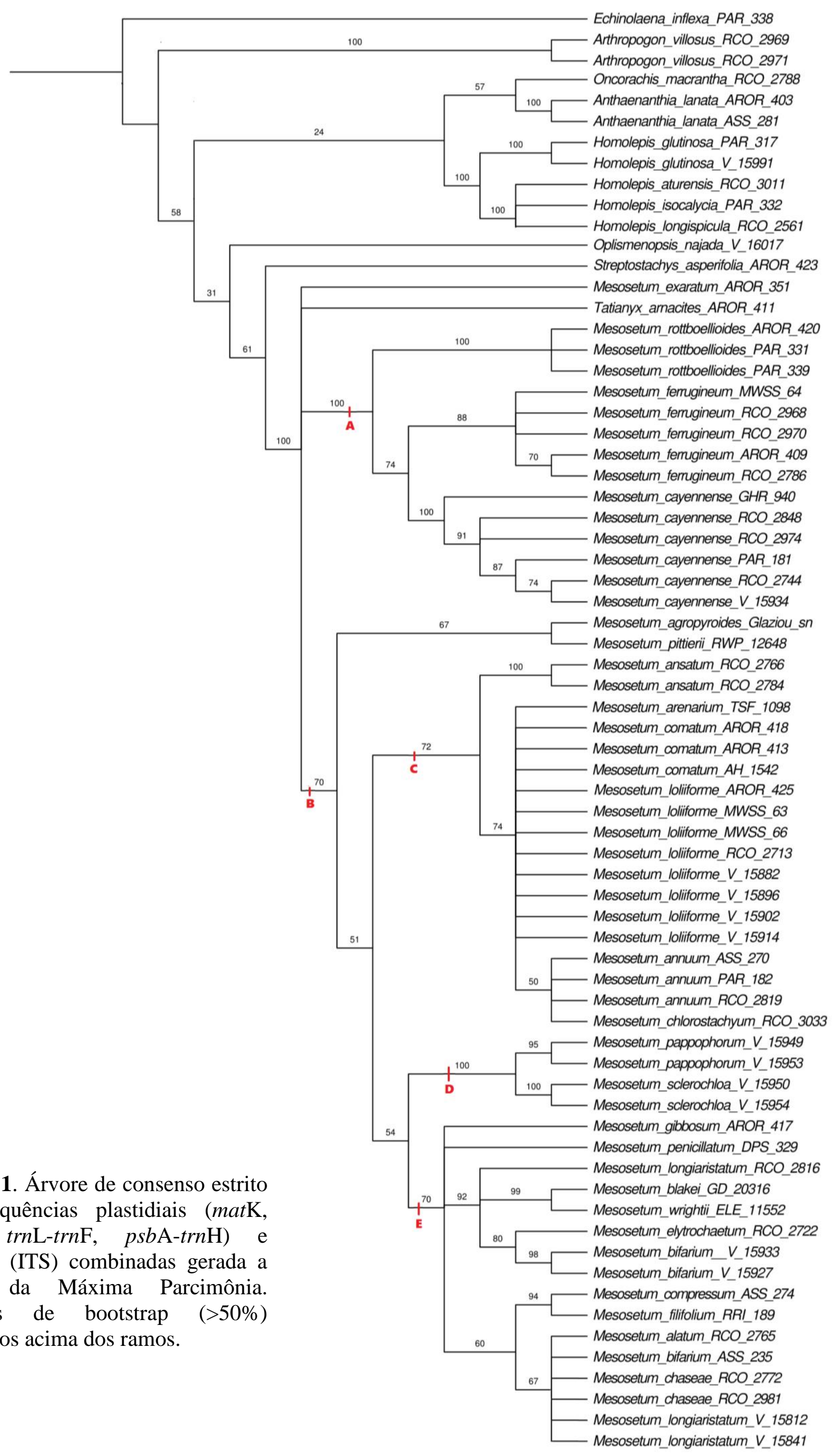

Anexo 1. Árvore de consenso estrito das sequências plastidiais (matK, $\operatorname{trn} \mathrm{L}, \quad \operatorname{trn} \mathrm{L}-t r n \mathrm{~F}, \quad p s b \mathrm{~A}-t r n \mathrm{H}) \quad \mathrm{e}$ nuclear (ITS) combinadas gerada a partir da Máxima Parcimônia. Valores de bootstrap ( $>50 \%)$ indicados acima dos ramos.
- Anthaenanthia lanata AROR 403

-Anthaenanthia_lanata_ASS_281

Homolepis_glutinosa_PAR_317

- Homolepis_isocalycia_PAR_332

Homolepis_longispicula_RCO_2561

Oplismenopsis_najada_V_16017

Mesosetum_rottboellioides_AROR_420

Mesotum rottboellioides PAR 331

- Mesosetum cayennense GHR 940

Mesosetum cayennense RCO 2744

$100 \quad$ Mesosetum_pappophorum_V_15953

Mesosetum_sclerochloa_V_15950

Mesosetum sclerochloa V 15954

Mesosetum gibbosum _AROR_417

(1)




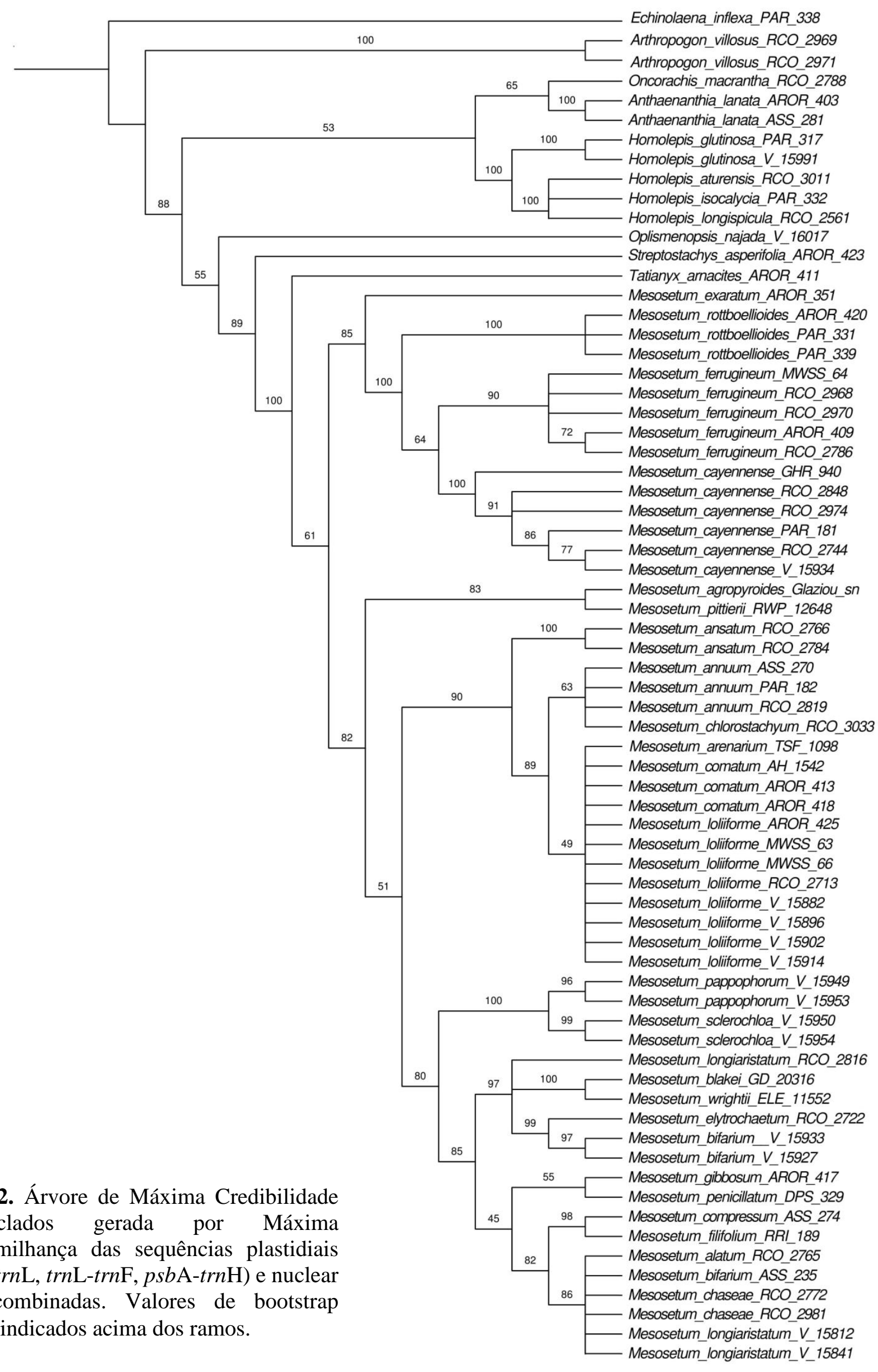

Anexo 2. Árvore de Máxima Credibilidade dos clados gerada por Máxima Verossimilhança das sequências plastidiais (matK, trnL, trnL-trnF, psbA-trn $\mathrm{H}$ ) e nuclear (ITS) combinadas. Valores de bootstrap (>50\%) indicados acima dos ramos. 


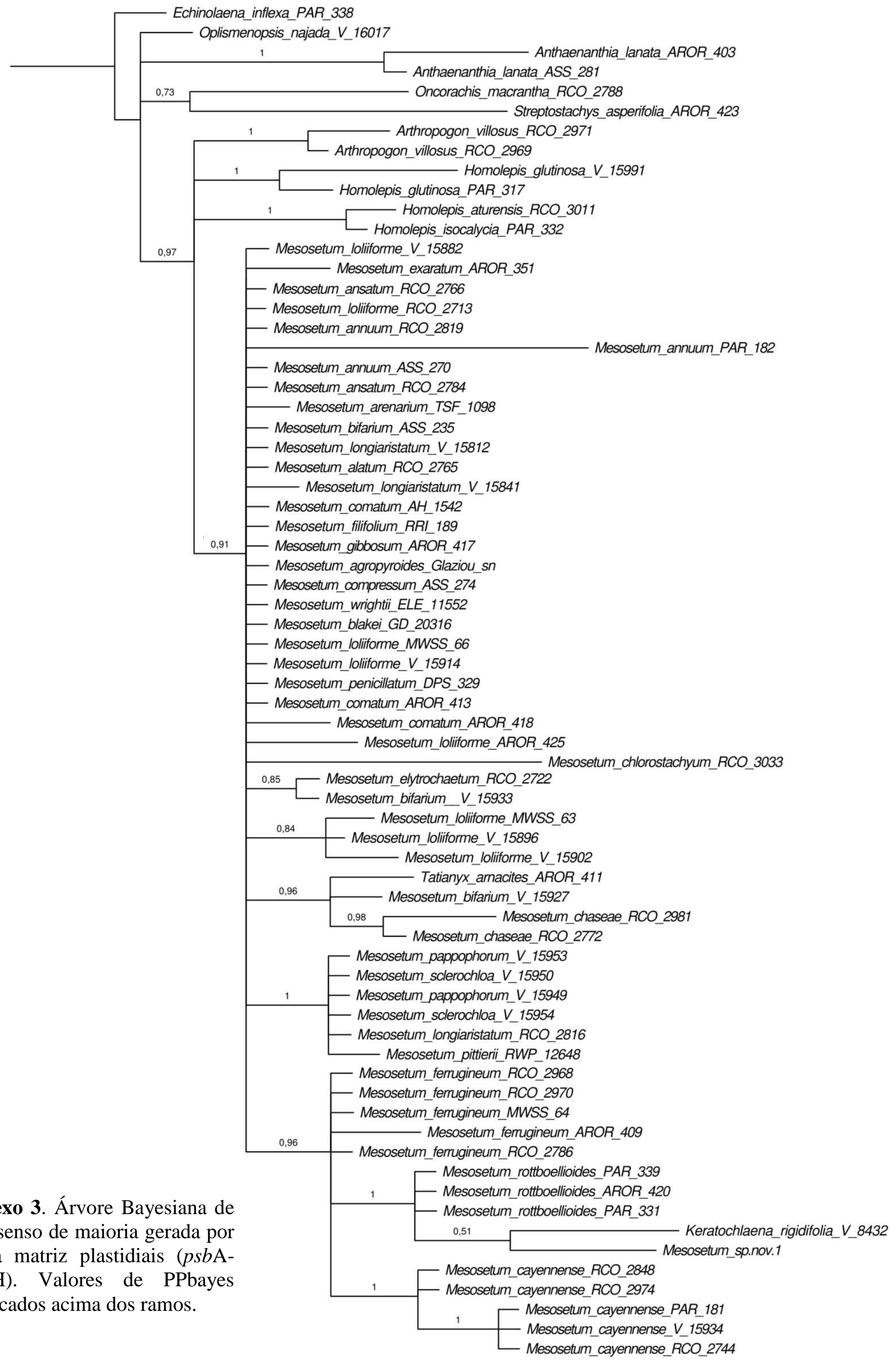

